DEPARTMENT OF THE INTERIOR

FRANKLIN K. LANE, Secretary

UNITED STATES GEOLOGICAL SURVEY

GEORGe OTIS SMIII, Director

\title{
CANNEL COAL IN THE UNITED STATES
}

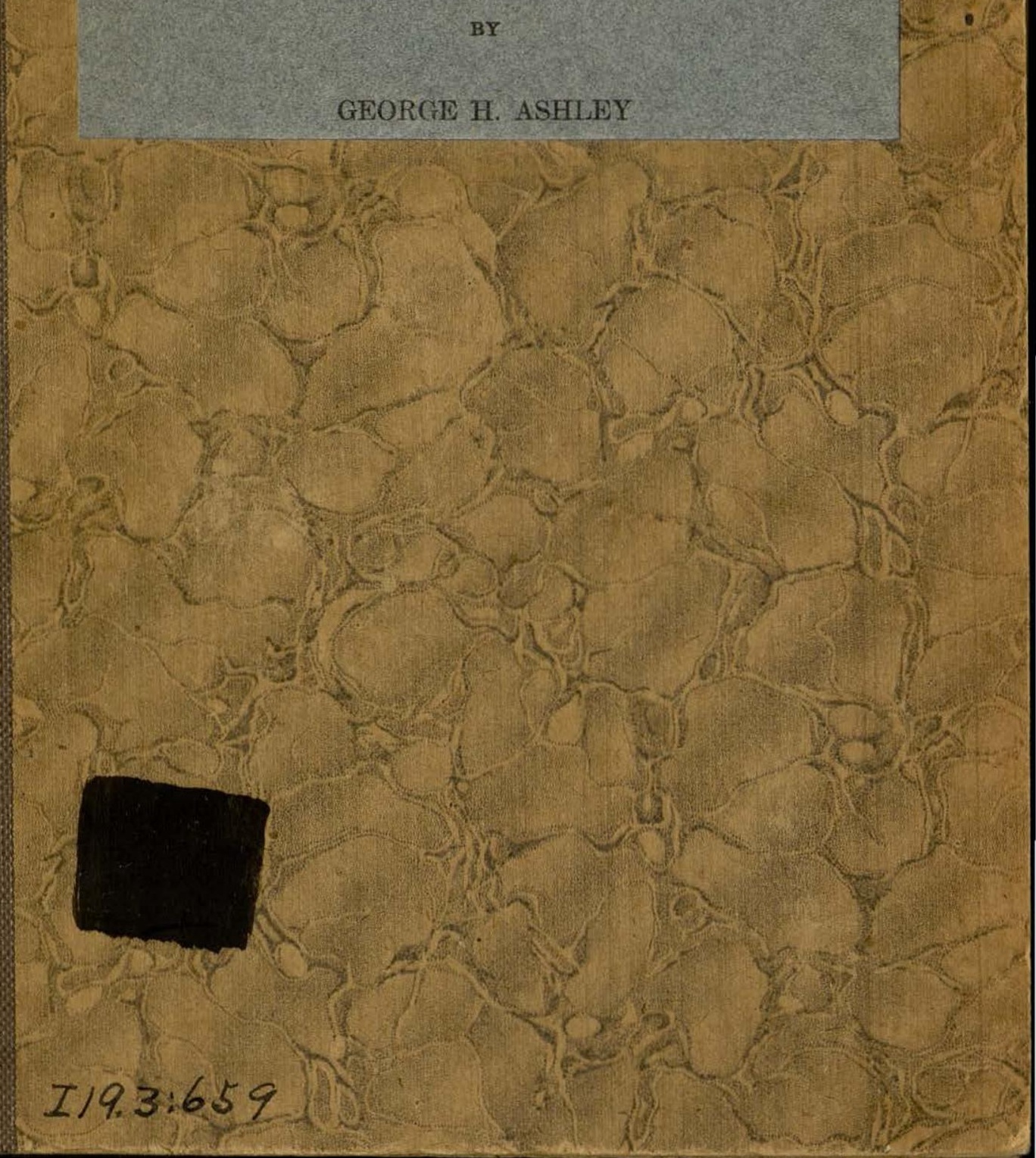




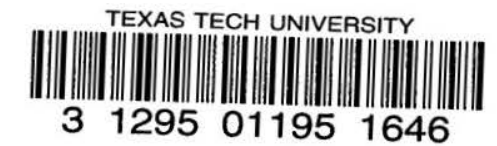




\section{$A D E-1590^{\circ}$}

\section{DEPARTMENT OF THE INTERIOR}

FrankLIN K. LANE, Secretary

United States Geological Survey
George Otis Smith, Director

\section{Bulletin 659}

\section{CANNEL COAL IN THE UNITED STATES}

BY

GEORGE H. ASHLEY

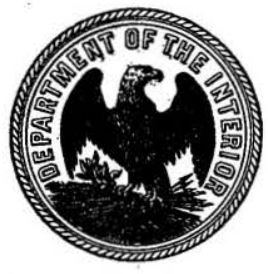

LIBKARY

TEXAS TECHNOLOGICAL COLLEGE LUBBOCK, TEXAS

WASHINGTON

GOVERNMENT PRINTING OFFIOE

1918 
ADDITIONAL COPIES

OF THIS PUBLICATION MAY BE PROCURED FROM THE SUPERINTENDENT OF DOCUMENTS GOVERNMENT PRINTING OFFICE WASHENGTON, D. C.

AT

15 CENTS PER COPY 


\section{CONTENTS.}

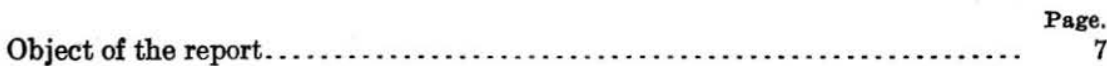

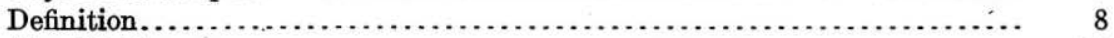

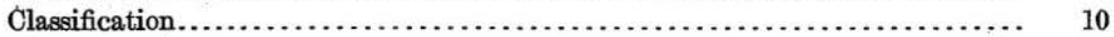

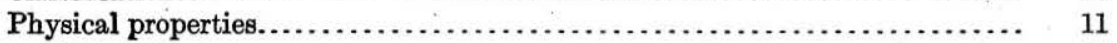

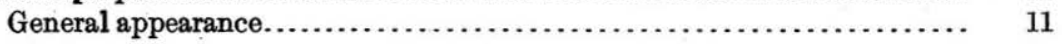

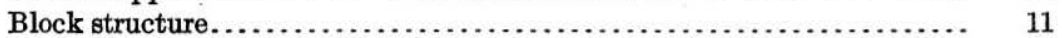

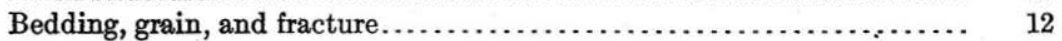

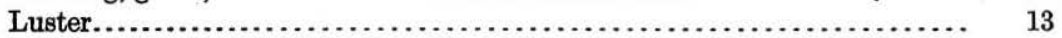

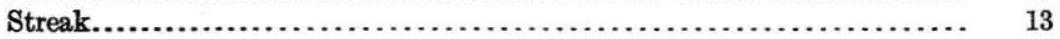

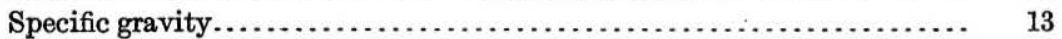

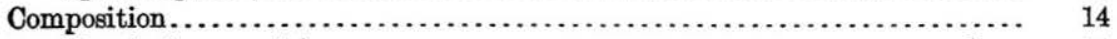

Physical composition.................................. 14

Chemical composition........................... 15

Comparison with other coals. . . . . . . . . 15

Analyses. . . . . . . . . . . 17

Analyses of cannel coal. . . . . . . . . . . . . 17

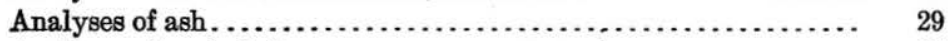

Analyses of occluded gas................................. 29

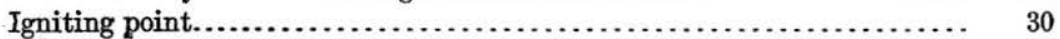

Origin . . . . . . . . . . . .

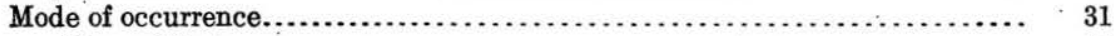

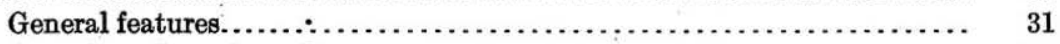

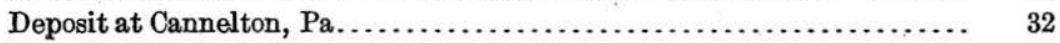

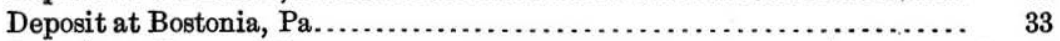

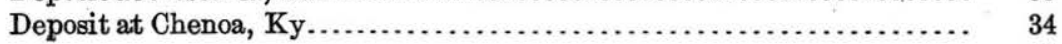

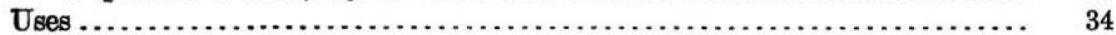

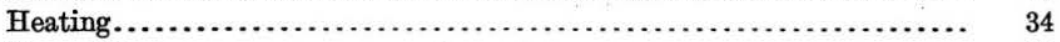

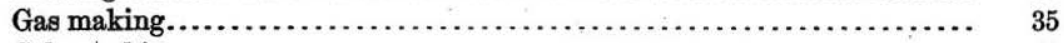

Coke making......................................... 41

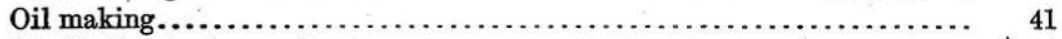

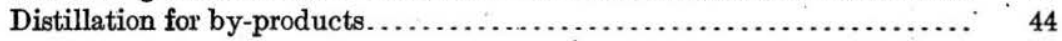

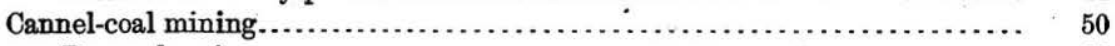

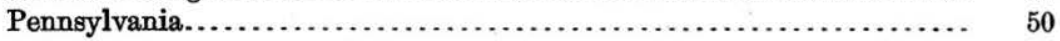

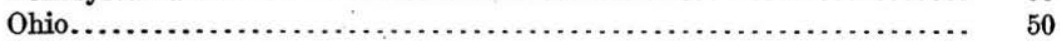

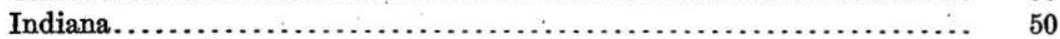

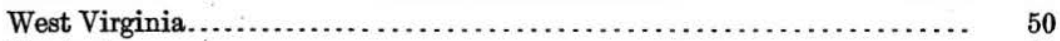

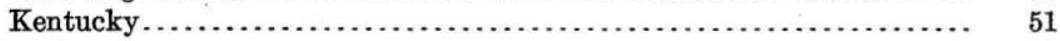

Production. . . . . . . . . . . . . . .

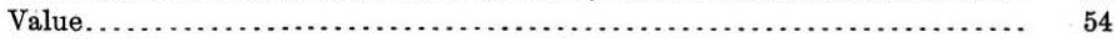

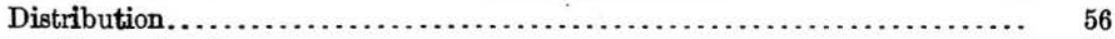

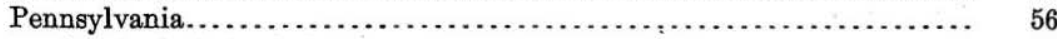

Revival of the industry . . . . .

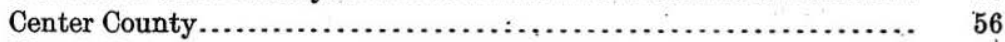

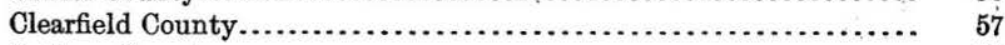

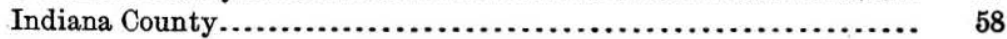


Distribution-Continued.

Pennsylvania-Continued. Page.

Westmoreland County........................................ 59

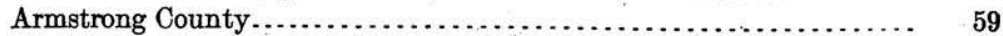

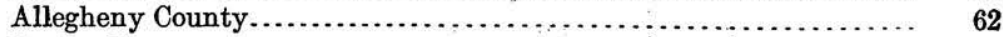

Butler County............................................... 62

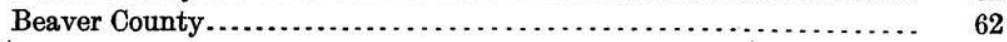

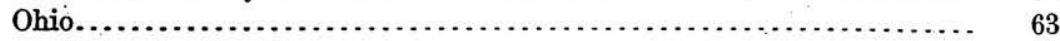

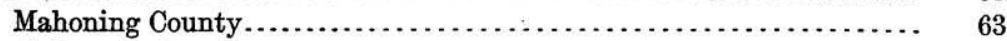

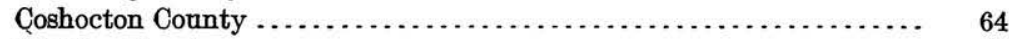

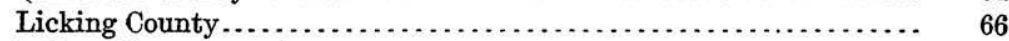

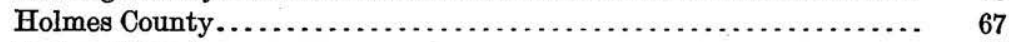

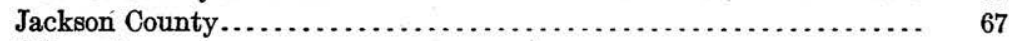

Scioto County................................................ 67

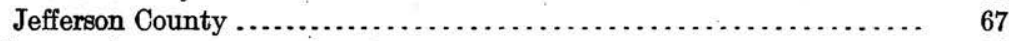

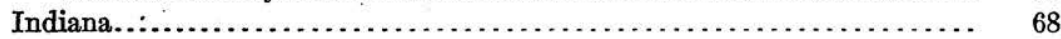

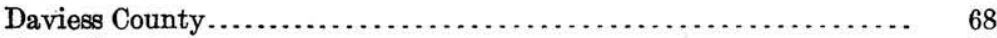

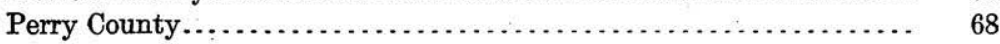

Parke County............................................. 69

Illinois..................................................... 69

Michigan........................................................... 69

West Virginia................................................... 70

Distribution of the coal .............................. 70

Preston County.............................................. $\quad 70$

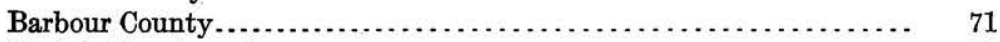

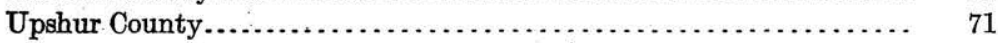

Braxton County.......................................... 73

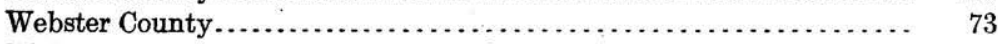

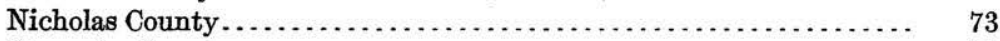

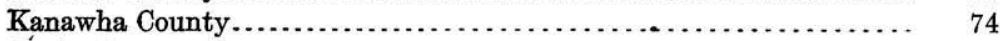

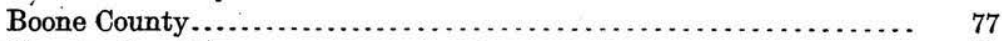

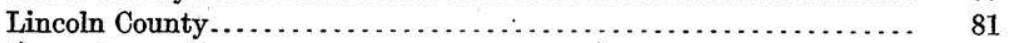

Logan County......................................... 82

Wayne County........................................... 82

Kentucky.............................................. 82

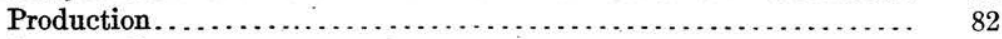

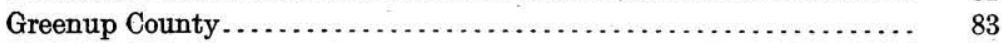

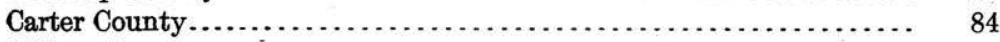

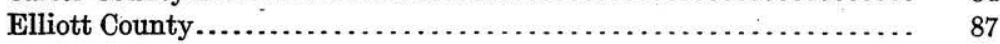

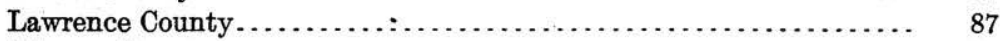

Johnson County.............................................. 87

Morgan County.......................................... 89

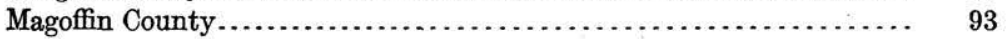

Wolfe County................................................ 93

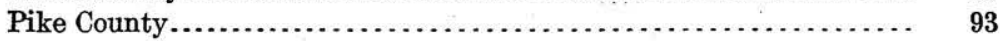

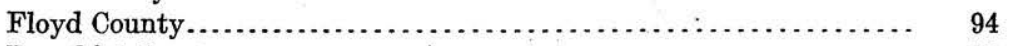

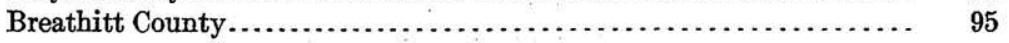

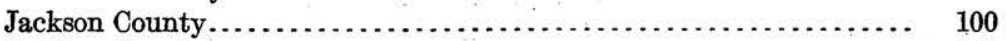

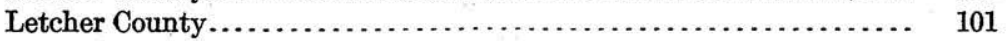

Leslie County ........................................... 102

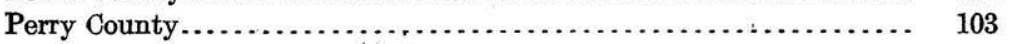

Harlan County ............................................... 104

Bell County............................................... 108

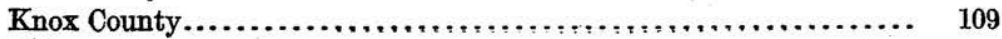


Distribution-Continued.

Kentucky-Continued. Page.

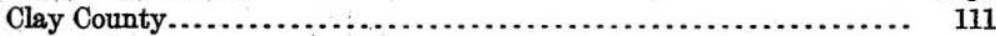

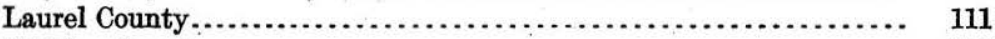

Whitley County.......................................... 111

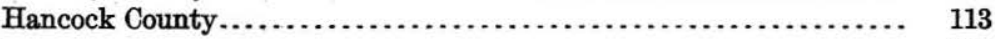

Tennessee..................................................... 113

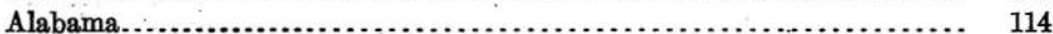

Iowa......................................................... 114

Missouri.................................................. 114

Occurrence of the coal..................................... 114

Callaway County......................................... 115

Cole County........................................... 116

Cooper County . . . . . . . . . . . . 117

Crawford County...................................... 117

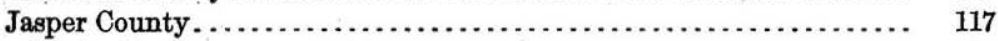

Lincoln County..................................... 117

Miller County............................................ 117

Moniteau County...................................... 117

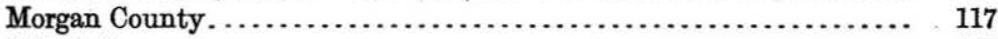

Saline County .......................................... 119

Arkansas.................................................... 119

Texas..................................................... 121

Utah....................................................... 122

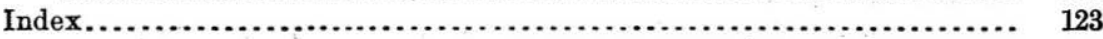

\section{ILLUSTRATIONS.}

Puge.

II. Views showing fracture of cannel coal.............................

III. Views showing structure of "curly" or "bird's-eye" cannel coal.. 14

IV. Cannel-coal mining, past and present....................... 34

V. Map of part of the eastern United States, showing locations of cannel-coal deposits and position of areas shown on large scale maps in this report.

VI. Sections of cannel coal in Kanawha County, W. Va..............

VII. Map of part of eastern Kentucky, showing locations of cannelcoal deposits.

VIII. Map of part of Missouri, showing location of cannel-coal deposits.

Figure 1. Cross sections of cannel-coal basins.

2. Sections of cannel coal in Center, Clearfield, and Indiana counties, $\mathrm{Pa}$.

3. Sketch map of cannel-coal area south of New Bethlehem, Arm-

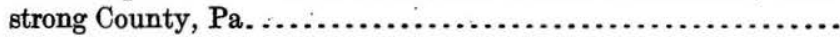

4. Sections of cannel coal in Armstrong and Beaver counties, Pa....

5. Sketch map of cannel-coal basin in Jefferson and Bedford townships, Coshocton County, Ohio..........................

6. Sections of cannel coal in Ohio . .............................

7. Sections of cannel coal in Indiana.......................... 68 
Frgure 8. Sections of cannel coal in Preston, Barbour, Webster, and Nicholas

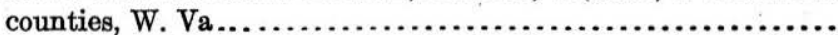

9. Map of part of West Virginia, showing locations of cannel-coal deposits............................................ $\quad 72$

10. Sections of cannel coal in Boone County, W. Va.............. 76

11. Sections of cannel coal on Pond Fork of Little Coal River, Boone County, W. Va................................... $\quad 79$

12. Sections of cannel coal in Lincoln and Wayne counties, W. Va.. 81

13. Sections of cannel coal in Greenup County, Ky................ 83

14. Sections of cannel coal in Carter County, $\mathrm{Ky} \ldots \ldots \ldots \ldots \ldots \ldots \ldots . \quad 85$

15. Sections of cannel coal in Elliott and Johnson counties, Ky..... 88

16. Sections of cannel coal in Morgan County, Ky.................. 90

17. Sketch map of cannel-coal area around Cannel City, Morgan County,

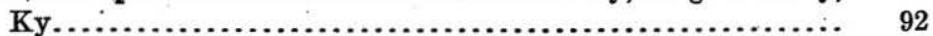

18. Sections of cannel coal in Magoffin County, Ky................. 93

19. Sections of cannel coal in Pike and Floyd counties, Ky ......... 94

20. Sections of cannel coal in part of Breathitt County, Ky.......... 96

21. Sections of cannel coal in part of Breathitt County, Ky.......... 98

22. Sections of cannel coal in Letcher County, Ky............... 101

23. Sections of cannel coal in Leslie and Perry counties, Ky ......... 103

24. Sections of cannel coal on Clover Fork of Cumberland River, Harlan County, Ky............................... 104

25. Sections of cannel coal in Harlan County, Ky............... 106

26. Sections of cannel coal in Bell and Knox counties, Ky.......... 109

27. Sections of cannel coal in Whitley and Hancock counties, Ky .... 112 


\section{CANNEL COAL IN THE UNITED STATES.}

By G. H. Ashuer.

\section{OBJECT OF THE REPORT.}

The recent rapid growth of the chemical industries of the United States, due in part to the shutting off of outside sources of supply, has brought the country to a point where it can provide for its own chemical needs and can reasonably expect that its products may soon enter the world's markets. The rapid extension of the use of motor-driven vehicles and the urgent demand for a larger supply of high explosives have led to a greatly increased demand for the lighter hydrocarbons and for the chemicals that are obtained by the nitration of toluene and phenol, which are derived by distillation from by-products of the distillation of coal.

One result of this increased activity has been a demand for information about cannel coal, one of the richest substances in hydrocarbons known, though the availability of these hydrocarbons for this growing chemical industry has yet to be proved. These hydrocarbons are now obtained by the distillation of oil and as by-products in the destructive distillation of coal. The primary products of this distillation of coal are artificial gas and coke or coke alone; the primary by-products are tar, ammonia, and benzol. The facts that cannel coal does not yield a coke that may be used for the purpose for which most coke is now marketed and that its cost has been about double that of the coals now used for making gas or coke have heretofore prevented its employment as a source of gas or coke. The recent increased demand for these by-products, however, is putting them into the class of primary products, and if the demand continues to increase as it has of late new and independent sources of hydrocarbons must be utilized. This fact has recently led to an increasing number of inquiries of the United States Geological Survey regarding cannel coal and has led to the preparation of this report.

The work done on this report has made more evident the already well-known lack of any general discussion of cannel coal. Cannel 
coal is mentioned incidentally in a great many publications but in most of them only as a matter of curiosity, and even if it may be mentioned in the text of a book it has seldom been noted in the index, so that in reviewing the literature it has been necessary to go over many books page by page. Most of the longer memoranda on the cannel coal of this country were made during or just after the period of great interest in cannel coal, between 1855 and 1860, or just before the discovery of our great reservoirs of petroleum. At that time it was the principal source of our oil supply, nearly 60 distilleries being in operation in the United States in 1860. The discovery of rock oil naturally knocked the bottom out of the "coal-oil" industry, but the new growing demand for hydrocarbons may lead to a revival of the mining of cannel coal. In this connection it is desirable to call attention to a fact brought out elsewhere in this report-that all socalled cannel coals are not equally valuable for producing oil and gas, notwithstanding the prices at which they may now be selling for use in grates; two cannel coals may be of equal value for use in grates and may therefore now bring the same price, but one may have twice the value of the other for distillation for oil or gas.

The present paper is not intended as an original contribution to the subject, though the writer has drawn on his own notes in describing many of the deposits mentioned, particularly those in Pennsylvania, Indiana, and parts of West Virginia and Kentucky. It consists of a preliminary review of well-known facts about the character, uses, and value of cannel coal and brief descriptions of workable deposits of cannel coal, including cross sections of the beds, and it gives such analyses of the coal as are available.

\section{DEFINITION.}

Cannel coar is a massive, noncaking, tough, clean, block coal of fine, even, compact grain, dull luster, commonly conchoidal cross fracture, having a typical low fuel ratio, a high percentage of hydrogen, easy ignition, long yellow flame, black to brown greasy streak, and moderate ash, pulverulent in burning. It is essentially a rock derived by solidification and partial distillation or oxidation of water-laid deposits consisting of or containing large quantities of plant spores and pollen grains and more or less comminuted remains of low orders of water plants and animals.

In such a deposit of decaying spore and pollen material, containing both vegetal and animal débris to which Potonié ${ }^{1}$ has given the name "sapropel," there may be admixed greater or less quantities of mud or of woody or peaty material. The high volatile content and high hydrogen of cannel coal appears to be derived from the spore

1 Potonie, Henry, Die Entstehung der Steinkohle, 5th ed., p. 3, 1910. 
and pollen and waxy material and, to an unknown extent, from animal remains. The greater the admixture of woody or peaty material derived from the usually adjoining peat marshes, the more closely the cannel coal resembles chemically the associated bituminous coals and the smaller the proportionate yield of oil by distillation. Cannel coals in common with other coals also differ in character and value because of changes they undergo, first by decomposition and later by physical and chemical changes due to pressure and heat, especially to pressure due to the weight of superimposed rocks and to the horizontal thrusts that have locally folded and otherwise disturbed the earth's crust. The effect of these forces has been somewhat similar to that of slow distillation, driving off first the moisture, then the higher hydrocarbons, then the heavier hydrocarbons, and ultimately, if continued, nearly or quite all of the volatile hydrocarbons. It is evident that the deposit will be of greatest value as a source of oil at that point where the largest percentage of water and the smallest percentage of volatile hydrocarbons have been driven off. Such coal may be termed typical cannel. Coals which have not reached that rank may be called subcannels, and those which have much passed that point and have thus lost all their peculiar qualities may be called canneloid coals.

Typical cannel coal is distinguished from bituminous coal by the following contrasting features:

Bituminous coal.

1. Laminated.

2. Bright and dull bands.

3. Prismatic fracture.

4. Jointing imperfect.

5. More or less friable.

6. Disintegrates by weathering.

7. Soils the hands.

8. Percentage of fixed carbon higher than that of volatile matter.

9. Derived from woody or peaty deposits grown in place.

10. Basins commonly extensive.

11. Commonly yields on distillation less`than 10,000 cubic feet of gas to the ton.

12. Candlepower of gas commonly less than 17.

13. Commonly cakes in burning.

14. Coke usually strong.

\section{Cannel coal.}

1. Massive.

2. Uniform velvety or satiny luster.

3. Conchoidal fracture.

4. Jointing regular and striking.

5. Tough and elastic.

6. Weathers slowly; used for foundations of barns, etc.

7. Does not soil the hands.

8. Percentage of fixed carbon typically lower than that of volatile matter (except in lean cannels).

9. Derived mainly from spores, pollen, etc., brought in by wind and water.

10. Basins rather small; many are narrow channels.

11. Commonly yields on distillation more than 10,000 cubic feet of gas to the ton.

12. Candlepower of gas commonly more than 20.

13. Does not cake in burning.

14. Coke pulverulent. 
Bituminous coal-Continued.

15. Yield of oil on distillation commonly less than one barrel to the ton.

16. Less than 6 per cent hydrogen.

17. Ignites with difficulty.

18. Streak commonly black.
Cannel coal-Continued.

15. Yield of oil on distillation from one to more than two barrels to the ton.

16. More than 6 per cent hydrogen.

17. Ignites readily.

18. Streak commonly brown.

\section{CLASSIFICATION.}

The subcannel coals may be divided into two ranks, corresponding to lignite and subbituminous coals, which may be distinguished as brown and black subcannels.

Cannels may be divided into two or three ranks-boghead cannels having a fuel ratio of 0.5 or less, named from their resemblance to the famous "boghead" of Scotland; cannels (including boghead), having a fuel ratio of 1 or less; and semicannels, having a fuel ratio of more than 1. A fuel ratio of 1 is a convenient point at which to draw the line between the typical and the lean cannels, but further research may show that it should be drawn a little higher or a little lower. This high fuel ratio may be due to dynamo-chemical changes, which decrease the percentage of volatile hydrocarbons, or to admixture of peaty elements in the original deposits, or to both.

If the fuel ratio of a cannel coal is more than 1 and the pure coal of the associated bituminous coal contains less than 65 per cent fixed carbon, the high fuel ratio is probably due to the presence of peaty elements in the original deposits. As such coals stand between bituminous and cannel coal they are properly called semicannels. On the other hand, low-volatile cannels that are associated with high-carbon bituminous coals may have been originally either nonpeaty cannels or peaty cannels. A detailed investigation of the constitution of these coals would doubtless reveal significant differences between these types and future distillation practice may disclose economic differences-in the yield of certain hydrocarbons, for instance. At present, however, for practical purposes they may all be considered lean cannels or semicannels.

Cannels that are associated with semibituminous, semianthracite, and anthracite coals and that have so far lost any peculiar advantage over the coals with which they are associated as not to be separated in mining, marketing, or use may be classified, according to their nature, as canneloid, semibituminous, semianthracite, or anthracite.

Cannel coals may therefore be classified, largely in genetic sequence, as follows:

1. Subcannel coal:

(a) Brown subcannel, of brown coal or lignitè rank.

(b) Black subcannel, of subbituminous rank. 
2. Cannel coal of bituminous rank:

(a) Boghead cannel (fuel ratio less than 0.5).

(b) Cannel, typical (fuel ratio less than 1).

(c) Lean cannels or semicannels (fuel ratio more than 1).

3. Canneloid, semibituminous, semianthracite, or anthracite coal.

The grade of a cannel coal varies with the amount of ash or other impurity it contains. The bodies of water in which the cannels were laid down were at some places subject to inflows of mud, so that the deposit at such places might contain from less than 5 per cent to 100 per cent of ash, or might range from a pure cannel coal to a nonbituminous shale. The line between a coal and a shale has never been sharply drawn, but the suggestion is here made that material which, when burned, breaks down and yields an ash that goes through the grate bars and shows no tendency to maintain its original shape is a coal, and that material which on burning yields an ash that tends to maintain its original shape is a shale. The exact percentage of ash that should distinguish a coal from a shale can not yet be given, but until more exact figures are available it is suggested that material that yields less than 33 per cent of ash be considered a coal.

High ash, though it reduces the grade of a cannel coal, does not necessarily mean that the coal will not yield a large proportion of hydrocarbons, for many original deposits were not laid down in peat bogs and so contain little woody material. Such deposits may therefore yield coal that is rich in oil-making elements even though they may be high in ash. Thus an analysis of Scotch boghead (p. 28) shows nearly 20 per cent of ash, but more than 70 per cent of volatile hydrocarbons and about 10 per cent of fixed carbon. Some of the boghead shales of this country will yield from a barrel to more than two barrels of crude oil per ton of rock. Thus, as David White has suggested, such coals may be arranged in a series ranging from cannels through boghead cannels and cannel bogheads to bogheads.

The Scotch boghead and other bituminous shales have long been distilled for oil, and such shales are abundant in this country. Nearly all the coals described in this report are cannel coals, but a few analyses of canneloid coals are given for comparison, and a typical brown subcannel from Arkansas, a black subcannel from Utah, and a subcannel from Texas are briefly described.

\section{PHYSICAL PROPERTIES.}

Generat appearance-Cannel coal is a nearly dull black, homogeneous, fine-grained coal, much of it resembling black flint in fineness of grain and in fracture.

Block structure.-The bed is commonly split by vertical joints, many of which extend from the roof to the floor. These joints are 
nearly everywhere regularly spaced and occur in two sets that run nearly at right angles to each other. As a result the coal may mine out in blocks having almost a square cross section and a thickness ranging from the full thickness of the bed down to a few inches. The size of the blocks depends on the distance between the joints. In some places such joints are several feet apart; and the coal may be mined out in cubes measuring several feet on an edge. More commonly it is mined in cubes the size of a man's head or smaller. (See Pl. I.) This cubical structure is shown on a small scale in Plate II, $B$.

Bedding, grain, and fracture.-Cannel coal generally shows no bedding or horizontal banding but is even grained or massive throughout. At some places, however, as at Boghead, Ky., blocks of coal that are greatly weathered may have somewhat the appearance of the charred edges of a burned book and may split along bedding places into thin sheets, one of which, measured by the writer, had a thickness of $\frac{1}{250}$ of an inch. In other cannels weathering brings out a wavy structure, possibly the results of ripple marks on the original deposit. A coal that will weather into thin sheets may, when unweathered, have the massive appearance and fracture of a piece of nontransparent black flint. The evenness of grain permits the coal to be carved into desk weights or other objects. Indeed, the well-known material jet, used for making jewelry, is only a variety of cannel coal. The cross fracture of cannel coal is generally conchoidal, like that of glass. (See Pl. II, A.)

In some districts the cannel coal is what is known locally as "bird'seye" or "curly." The fracture surfaces of this variety are small and irregular. (See Pl. III.) The two varieties may be found in the same mine, as were two of the specimens shown in Plates II and III.

Cannel coal that occurs in rocks which have been subjected to folding or which have been under heavy stress lose their characteristic structure and fracture and may become friable or tender and acquire a fracture and structure like that of the surrounding bituminous or anthracite coal, which it then resembles chemically as well as physically, though the two are distinguishable. Thus, at the Lula mine, near Philipsburg, Center County, within a few miles of the eastern edge of the bituminous coal field of Pennsylvania, there is, a coal that was evidently originally a cannel, as it still has the typical dull, satiny luster of cannel, but its fracture is only slightly conchoidal and that of most of it is similar to the fracture of the associated bituminous coal, which in that area is long grained. It has also become friable, and instead of breaking, as usual, into blocks that split readily with the bedding and only with difficulty across the 


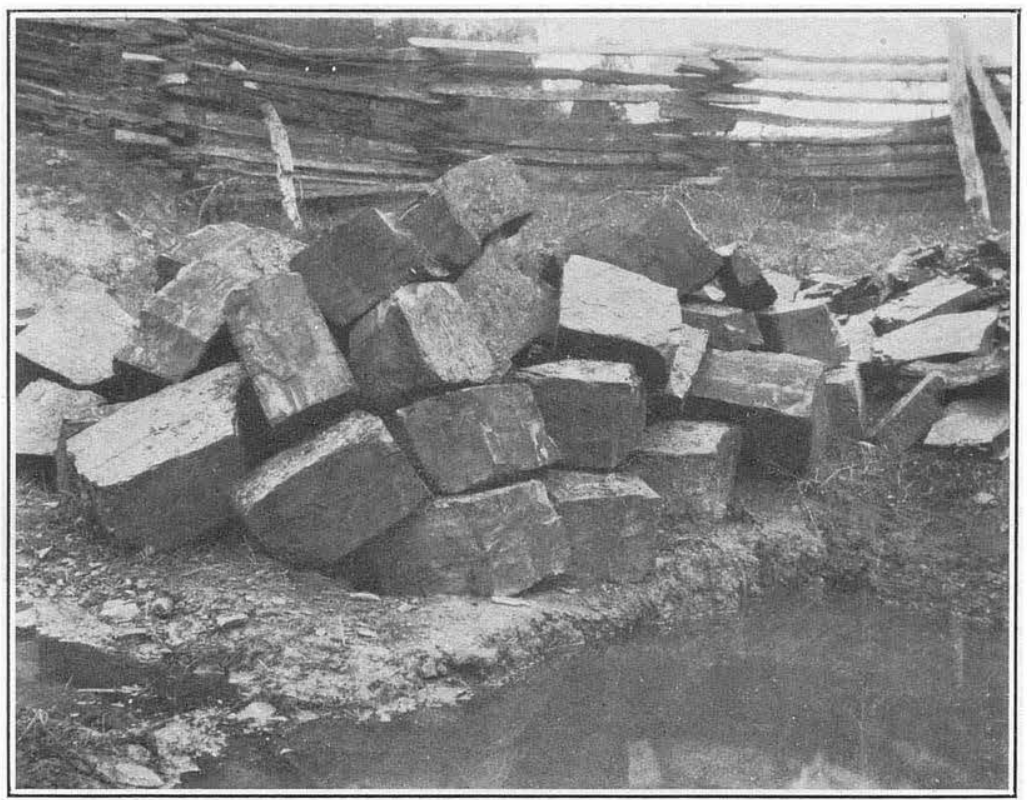

A.

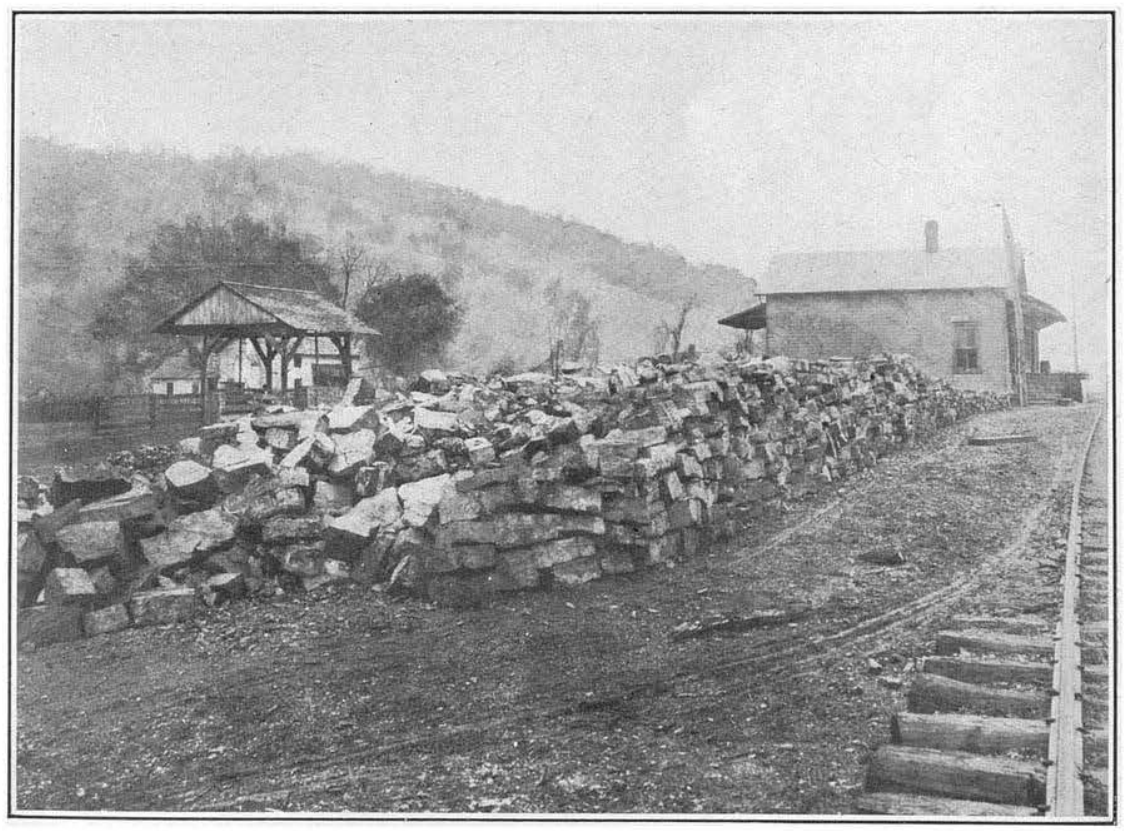

$B$.

VIEWS SHOWING BLOCK OR CUBICAL STRUCTURE OF COAL. 


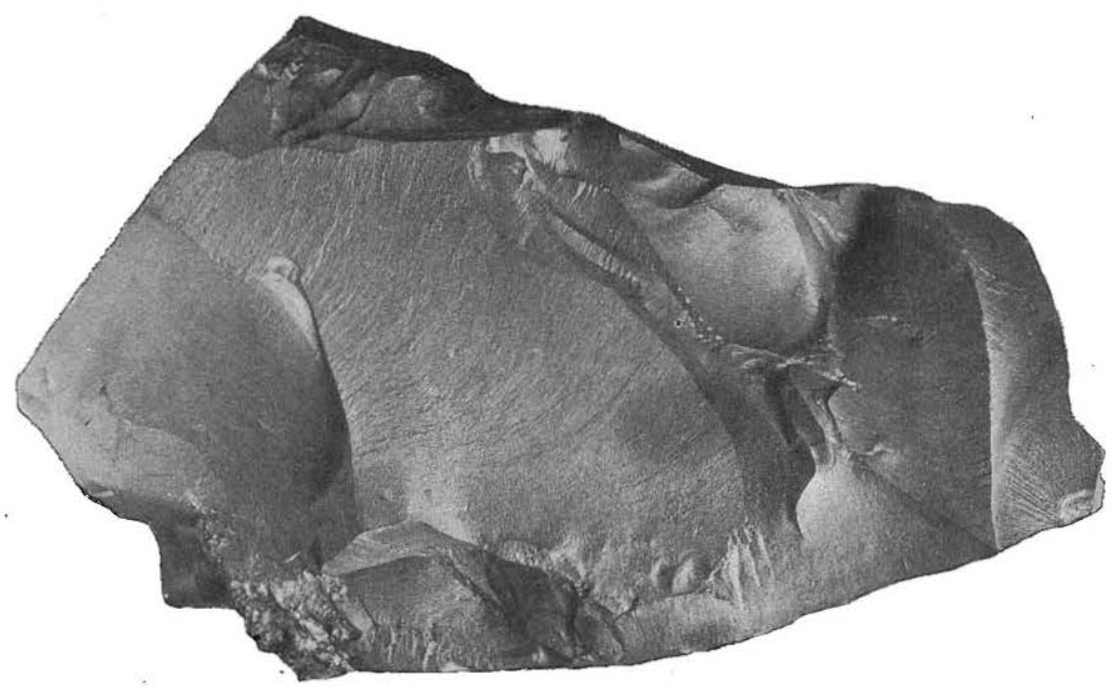

A.

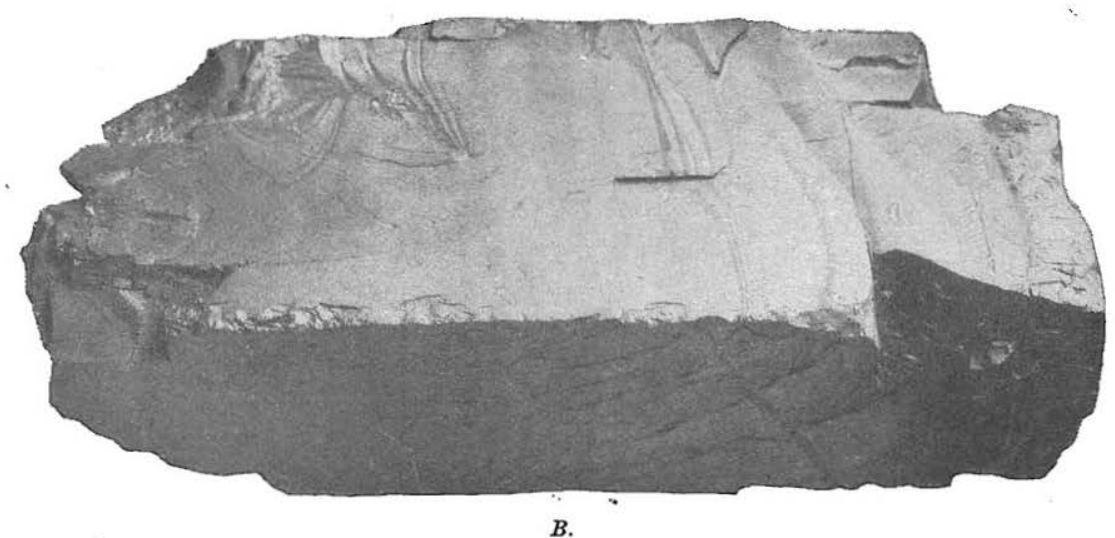

VIEWS SHOWING FRACTURE OF CANNEL COAL. 
bedding it may be shattered by a slight blow of the hammer into slivers or chunks 6 inches to a foot or more long and 2 or 3 inches through, whose longest drameter is perpendicular to the bedding planes; and if such a chunk falls only a few feet to the ground it is likely to break into pieces, none of which are more than 2 inches long by half an inch square; and if handled much, most of this coal will crumble to fine dust. Obviously, this structure is due to the intense pressure to which the coals and the rocks that contained it have been subjected. David White has called attention to lenses of anthracite that still have enough of the features of cannel to indicate that they were originally true cannel coals, though to-day they are true anthracite. (See pp. 16, 17.)

Luster-Cannel coal has a dull, even velvety sheen, resembling that of a fine-dressed black leather-new harness leather. The curly variety, if examined at right angles to the bedding, shows a dead black matrix mottled by dully glistening spots. (See Pl. III.) Some "bird's-eye" cannel has an irregular pitted appearance, as illustrated by Hendrie. ${ }^{1}$

Streak.-The streak of cannel coal-that is, the color of the mark it makes when rubbed against some other substance-is brown to black. Typically it is an oily brown.

Specific gravity.-The specific gravity of pure cannel coals is less than the average of bituminous coals that contain the same percentage of ash, and in most cannels that have the same percentage of ash the larger the percentage of volatile matter the lighter the coal-that is, the less its specific gravity. The following table shows, first, the change in specific gravity with change of ash where the fuel ratio remains about the same; second, the change in specific gravity with change in fuel ratio where the ash remains about the same.

Relation of specific gravity to percentage of ash in cannel coal.

\begin{tabular}{|c|c|c|c|c|c|}
\hline Locality. & $\begin{array}{l}\text { Specific } \\
\text { gravity. }\end{array}$ & Ash. & $\begin{array}{l}\text { Volatile } \\
\text { matter. }\end{array}$ & $\begin{array}{l}\text { Fixed } \\
\text { carbon. }\end{array}$ & $\begin{array}{l}\text { Fuel } \\
\text { ratio. }\end{array}$ \\
\hline 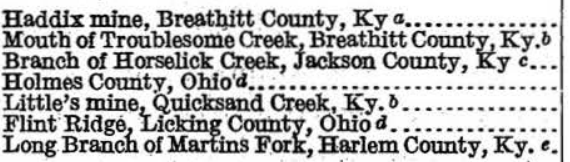 & $\begin{array}{l}1.21 \\
1.265 \\
1.32 \\
1.38 \\
1.39 \\
1.43 \\
1.51\end{array}$ & $\begin{array}{l}3.00 \\
7.30 \\
8.76 \\
9.9 \\
11.44 \\
13.2 \\
24.6\end{array}$ & $\begin{array}{l}48.9 \\
47.0 \\
43.6 \\
44.7 \\
43.1 \\
40.2 \\
34.6\end{array}$ & $\begin{array}{l}47.0 \\
44.4 \\
45.5 \\
42.9 \\
43.3 \\
44.0 \\
39.4\end{array}$ & $\begin{array}{r}0.96 \\
.94 \\
1.04 \\
.96 \\
1.04 \\
1.09 \\
1.14\end{array}$ \\
\hline
\end{tabular}

$a$ Hodge, J. M., Report on the cosls of the three forks of the Kentucky River: Kentucky Geol. Survey Bull. 11, p. 27, 1910.

$b$ Peter, Robert; Chemical analyses: Kentucky Geol. Sturvey Rept. A, pt. 1, p. 221, 1884.

c Idem, p. 273.

d Newberry, J. s., Ohio Geol. Survey Rept. Progress for 1870, p. 420, 1871

e Peter, Robert, op. cit., p. 265.

1 Hendrte, Charles, Some Kentucky cannels : Kentucky Inspector of Mines Tenth Ann. Rept., p. 89, 1894. 
Relation of specific gravity to fuel ratio in cannel coal.

\begin{tabular}{|c|c|c|c|c|c|}
\hline Locality. & $\begin{array}{l}\text { Specific } \\
\text { gravity. }\end{array}$ & $\begin{array}{l}\text { Fuel } \\
\text { ratio. }\end{array}$ & $\begin{array}{l}\text { Volatile } \\
\text { matter. }\end{array}$ & $\begin{array}{l}\text { Fixed } \\
\text { carbon. }\end{array}$ & Ash. \\
\hline 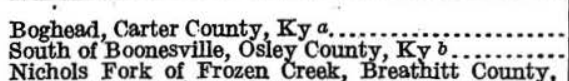 & $\begin{array}{l}1.14 \\
1.16\end{array}$ & $\begin{array}{r}0.42 \\
.54\end{array}$ & $\begin{array}{l}64.1 \\
59.7\end{array}$ & $\begin{array}{l}27.0 \\
32.3\end{array}$ & $\begin{array}{l}7.9 \\
7.4\end{array}$ \\
\hline 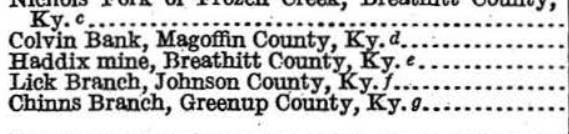 & $\begin{array}{l}1.18 \\
1.235 \\
1.21 \\
1.291 \\
1.33\end{array}$ & $\begin{array}{r}.60 \\
.72 \\
1.04 \\
1.34 \\
1.39\end{array}$ & $\begin{array}{l}58.8 \\
51.9 \\
46.6 \\
38.2 \\
36.9\end{array}$ & $\begin{array}{l}35.3 \\
37.5 \\
46.8 \\
51.0 \\
51.2\end{array}$ & $\begin{array}{l}4.7 \\
8.2 \\
5.00 \\
8.8 \\
7.1\end{array}$ \\
\hline
\end{tabular}

a Owen, D. D., Kentucky Geol. Survey Fourth Rept. 1858-59, p. 114, 1861.

$b$ Peter, Robert, op. cit., p. 315 .

c Peter, Robert, Chemical analyses: Kentucky Geol. Survey Rept. A, pt. 1, p. 221, 1884.

d Idem, p. 292.

e Hodge, J. M., Report on the coals of the three forks of the Kentucky River: Kentucky Geol. Survey Bull. 11, p. 27, 1910 .

$f$ Idem, p. 275

$g$ Crandali, A. R., Report on the Chinns Branch cannel coal district: Keniucky Geol. Survey Repts. on eastern coal field, C, p. 6 [200], 1884.

Were a large enough number of determinations made it might be possible to give, at least approximately, the relative weight-giving value of ash and fixed carbon. However, enough has been given to show the basis for the common rule that the lighter the cannel coal the greater its value.

\section{COMPOSITION.}

The composition of cannel coal is determined in three ways-by microscopic examination, by dissolving out its component parts by pyridine or other solvent, and by destructive distillation or analysis.

\section{PHYSICAL COMPOSITION.}

The fundamental differences between typical cannel coal and typical bituminous coal appear to result from the fact that they were deposited under different conditions and consequently were composed of different original substances, which formed different decomposition products. It is now very generally agreed that most coal is transformed peat. Cannel coal, however, appears to have been formed in part from decayed spores or pollen and other floating remains of plants, as well as of remains of minute or slow-moving animals, such as are commonly found to-day in the bottoms of lakes. In a peat bog decay is only partial, but in the more open waters of lakes or lagoons, whether surrounded by bogs or not, decomposition is likely to affect almost the whole mass of organic matter that settles to the bottom except the spore cases, or outer coverings of the spores, which are naturally very resistant, and some few other end products. These spores appear to have been mainly those of ferns and related plants, which were abundant during the Carboniferous period as well as later, and most of which were much larger and on the whole far more abundant than those of to-day. Associated with material 


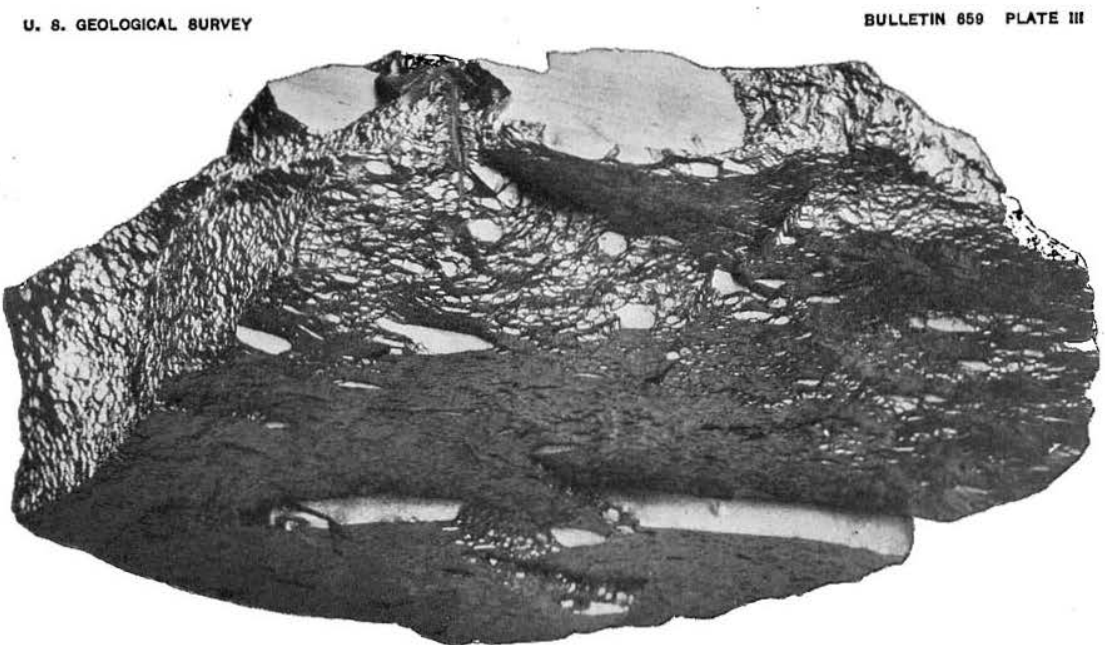

$A$.

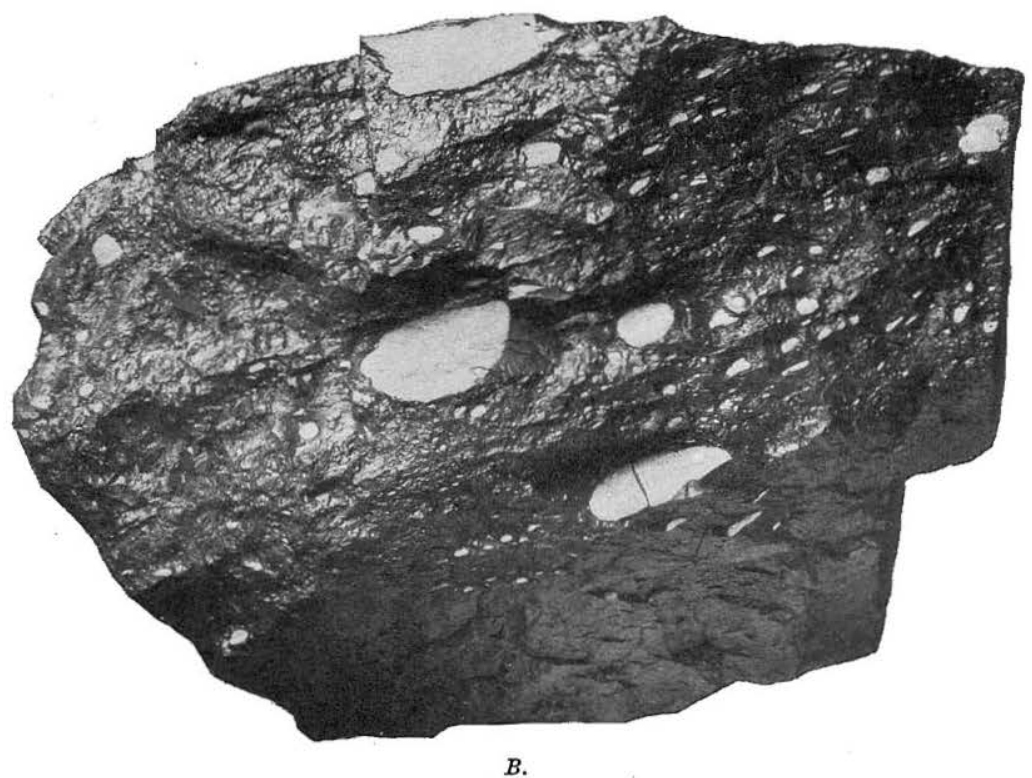

VIEWS SHOWING STRUCTURE OF "CURLY" OR "BIRD'S-EYE" CANNEL COAL. 

of this type in some deposits of cannel coal, according to Newberry, ${ }^{1}$ there are abundant remains of fish and other free-swimming animals: Many of the spore cases, though flattened, are well preserved; others are broken down into a pulp or ooze. According to Von Gümbel, Bertrand, Renault, and Thiessen ${ }^{2}$ cannel coal, when viewed under the miscroscope in thin sections, consists mainly of spore cases in different stages of decay, with which are associated a very minor proportion of other bodies, like particles of resin, resistant seed coats, fragments of cuticle, and waxy bodies. In view of the difference in resistance to decay between the spore cases and the watergrowing plants, such as algae, it may be doubted whether the presence of spore cases only should be taken as proof that spores have been the main source of the carbonaceous material. Associated with this pure coal matter is a greater or less proportion (10 to almost 100 per cent) of clay or sand, which forms the ash. As the proportion of shaly matter increases the coal changes to a bituminous or oil shale and locally to a nonbituminous shale.

CHEMICAI COMPOSITION.

COMPARISON WITH OTHER COALS.

Most cannel coals may be distinguished from other bituminous coals by the large proportion of high-candlepower volatile matter that is driven off from them at high temperatures or the large proportion of oil that is driven off at low temperatures and by the high percentage of hydrogen they yield on ultimate analysis. Doubtless more fundamental chemical differences would be found were it possible to determine exactly the chemical combinations existing in the coals, but no method of doing this completely has yet been devised. An ordinary analysis of coal may show either the proportions of the elements it contains or the products that may be obtained by heating the coal to a certain high temperature-the products differing according to the temperature and pressure applied.

By the usual methods of analysis, bituminous coals will yield from 45 to 75 per cent of fixed carbon and from 20 to 45 per cent of volatile matter. The fuel ratio of such coals - that is, the ratio of the fixed carbon to the volatile matter-will range from 1 or a little over for the coals of the Mississippi Valley to 2 or more for the coals in the eastern Appalachian field.

1 Newberry, J. S., On the mode of formation of cannel coal : Am. Jour. Sci., 2d ser., vo1; 23, p. 214, 1857.

2. White, David, and Thiessen, Reinhardt; The origin of coal : Bur. Manes Bull. 38; pp. 248. et seq., 1913. 
In contrast with these figures, typical cannel coals contain from 25 to 45 per cent fixed carbon and from 45 to 70 per cent volatile matter, or gas, the fuel ratio ranging from 1 down to 0.5 or less. This difference is shown by comparing the analysis of a sample of cannel coal with that of a sample of bituminous coal from a different bench of the same bed.

Analyses of cannel and bituminous coal from the same bed.

[C, cannel coal; B, bituminous coal.]

\begin{tabular}{|c|c|c|c|c|c|c|c|c|}
\hline \multirow{2}{*}{ Locality. } & \multicolumn{2}{|c|}{$\begin{array}{l}\text { Volatile } \\
\text { matter. }\end{array}$} & \multicolumn{2}{|c|}{ Fixed carbon. } & \multicolumn{2}{|c|}{ Ash. } & \multicolumn{2}{|c|}{ Fuel ratio. } \\
\hline & $\mathbf{c}$ & B & c & B & C & B & c & B \\
\hline $\begin{array}{l}\text { Boghead, Carter County, Ky. } a \ldots \ldots \ldots . . . . \\
\text { Troublesome Creek, Breathitt Coun }\end{array}$ & 64.1 & 35.9 & 27,0 & 53.3 & 7.9 & 6.5 & 0.42 & 1.49 \\
\hline $\begin{array}{l}\text { ty, Ky b b C̈reek, Breathitt County, } \\
\text { Quicksand }\end{array}$ & 48.2 & 38.0 & 44.2 & 52.0 & 4.7 & 4.7 & .91 & 1.37 \\
\hline 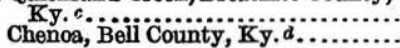 & $\begin{array}{l}66.2 \\
51.6\end{array}$ & $\begin{array}{l}39.6 \\
32.6\end{array}$ & $\begin{array}{r}29.7 \\
40.4\end{array}$ & $\begin{array}{l}48.0 \\
62.3\end{array}$ & $\begin{array}{l}3.6 \\
7.0\end{array}$ & $\begin{array}{r}10.6 \\
3.4\end{array}$ & .44 & $\begin{array}{l}1.21 \\
1.90\end{array}$ \\
\hline
\end{tabular}

a Owen, D. D., Kentucky Geol. Survey Fourth Rept., for 1858-59, p. 114, 1861.

b Hodge, J. M., Kentucky Geol. Survey Bull. 11, p. 27,1910.

$c$ Fohs, F. H., Coals of the region drained by the Quicksand creeks:- Kentucky Geol. Survey Bull. 18, p. $77,1912$.

field Ky.: U. S. Geol. Survey Prof. Paper 49, p. 95, 1906.

Many coals (see p. 12) that have the appearance and some that have the physical properties of cannel coal do not have the same high volatile content or low fuel ratio. The cannel coal that is so extensively mined at Cannel City, Ky., for example, has an average content of about 40 per cent of volatile matter and 50 per cent of fixed carbon, indicating a fuel ratio of about 1.25. Cannel coal mined at Cannelton, Ind., contains 28 to 35 per cent of volatile matter and 58 to 60 per cent of fixed carbon. The cannel coal of Armstrong County, Pa., contains 30 to 31 per cent of volatile matter and 46 to 49 per cent of fixed carbon.

The low content of volatile matter in Pennsylvania cannels may be due to the loss of volatile matter by the pressure to which the rocks in that field have been subjected. This probability is perhaps best shown by comparing the proportion of volatile matter and fixed carbon in coal taken from benches of the same bed at points across the State in a line from west to east. First are given analyses from the lean or semicannel and bituminous parts of a bed in Armstrong County near the center of the western coal field of the State; next are given analyses from the Blossburg field of Tioga County, where the coal is of semibituminous rank; then from the Barclay field in Bradford County, the next county to the east; and last from the semianthracite field of Bernice,. Sullivan County. 
Changes in benches of Pennsylvania coal undergoing loss of volatile matter.

\begin{tabular}{c|r|r|r|r|r|r|r|r}
\hline \multirow{2}{*}{ Location. } & \multicolumn{3}{|c|}{ Canneloid bench. } & \multicolumn{2}{|c}{ Bituminous or semibituminous } \\
bench.
\end{tabular}

a McCreath, A. S., Third report of progress in the laboratory of the Survey at Harrisburg: Pennsylvanis Second Geol. Survey Rept. M3, p. 57, 1881.

$b$ McCreath, A. S., Second report of progress in the laboratory of the Survey at Harrisburg: Pennsylvania Second Geol. Survey Rept. M2, p. 79, 1879.

$c$ Idem, p. 80.

d Idem, p. 82

David White ${ }^{1}$ has recently called attention to the fact that petroleum does not occur in rocks near a bed of coal containing 65 per cent or more of fixed carbon, having apparently been driven off by heat and pressure. The fact that the semicannel coals from Armstrong County lie east of the oil field of Pennsylvania indicates that the action which restricted the Pennsylvania oil field also made semicannel of cannel coals. As these semibituminous and semianthracite canneloid coals from Tioga County eastward have so little in common with the true cannels in commercial use, they are not further considered in this report.

The semicannel coals of the Mississippi Valley States, such as those in Kentucky, lie so close to cannel coals high in volatile matter as to lead to the belief that the two may have had a very different origin. Thus, at Cannel City, Ky., in a single hill, there are two coal beds, one a typical cannel containing 52 per cent of volatile matter and 36 per cent of fixed carbon and the other, which is mined mainly as cannel, containing only 40 per cent of volatile matter and 50 per cent of fixed carbon. The cause of this difference has not yet been determined.

\section{ANALYSES.}

ANALYSES OF CANNEL COAL.

The tables which follow give, first, a few recent proximate and ultimate analyses of cannel coals that were properly sampled; next a few earlier ultimate analyses; next, for reference, a large number of earlier proximate analyses, many of which represent averaged samples, though some have been made from selected coal or hand

\footnotetext{
${ }^{1}$ White, David, Some relations in origin between coal and petroleum: Washington Acad. Sci. Jour., vol. 5, p. 212, 1915.
}

$$
87775^{\circ}-18 \text { - Bull. 659-2 }
$$


specimens rather than from the average commercial product. The ash in most of these analyses is probably lower than in the commercial coal, but the analyses are of value as indicating the richness of the coal in volatile matter, and the ash, as determined in many of them, is probably not far from that of the commercial coal.

Practically all the earlier analyses of cannels were made of airdried coal that had been shipped to the laboratory in bags or boxes. rather than in air-tight metal or glass receptacles, such as are commonly used to-day. As all the coals of the Appalachian field, however, carry small percentages of moisture, the air-drying loss in most of the samples has been very small. Moisture has, however, not been included in most of the tables. 
Proximate and ultimate analyses of cannel and subcannel coals. ${ }^{a}$

\begin{tabular}{|c|c|c|c|c|c|c|c|c|c|c|c|c|c|c|c|c|}
\hline $\begin{array}{c}\text { No. } \\
\text { of } \\
\text { analy- } \\
\text { sis. }\end{array}$ & Locality and bed. & $\begin{array}{l}\text { Labora- } \\
\text { tory } \\
\text { No. }\end{array}$ & Kind. $b$ & $\begin{array}{l}\text { Condi- } \\
\text { tion.c }\end{array}$ & $\begin{array}{l}\text { Mois- } \\
\text { ture. }\end{array}$ & $\begin{array}{l}\text { Volatile } \\
\text { matter. }\end{array}$ & $\begin{array}{l}\text { Fixed } \\
\text { carbon. }\end{array}$ & Ash. & $\begin{array}{c}\text { Sul- } \\
\text { phur. }\end{array}$ & $\begin{array}{c}\text { Hydro- } \\
\text { gen. }\end{array}$ & Carbon. & $\begin{array}{l}\text { Nitro- } \\
\text { gen. }\end{array}$ & $\begin{array}{l}\text { Oxy- } \\
\text { gen. }\end{array}$ & $\begin{array}{l}\text { Air dry- } \\
\text { ing loss. }\end{array}$ & $\begin{array}{l}\text { Calo- } \\
\text { ries. }\end{array}$ & $\begin{array}{l}\text { British } \\
\text { thermal } \\
\text { units. }\end{array}$ \\
\hline & JOHNSON COUNTX, KY. & & & & & & & & & & & & & & & \\
\hline 1 & $\begin{array}{l}\text { Flambeau, southeast of, } 400 \text { yards up moun- } \\
\text { tain side, Flambeau mine, cannel bed, on } \\
\text { chain pillar (150 feet southeast of opening, } \\
\text { main entry 1, 18-inch cut). }\end{array}$ & 7133 & A & $\begin{array}{l}1 \\
2 \\
3\end{array}$ & 2.3 & $\begin{array}{l}48.4 \\
49.5 \\
55.5\end{array}$ & $\begin{array}{l}38.7 \\
39.6 \\
44.4\end{array}$ & $\begin{array}{l}10.4 \\
10.7\end{array}$ & $\begin{array}{l}1.20 \\
1.23 \\
1.38\end{array}$ & $\begin{array}{l}6.47 \\
6.36 \\
7.13\end{array}$ & $\begin{array}{l}71.98 \\
73.72 \\
82.59\end{array}$ & $\begin{array}{l}1.16 \\
1.19 \\
1.33\end{array}$ & $\begin{array}{l}8.70 \\
6.76 \\
7.57\end{array}$ & 1.5 & $\begin{array}{l}7,650 \\
7,835 \\
8,780\end{array}$ & $\begin{array}{l}13,770 \\
14,100 \\
15,800\end{array}$ \\
\hline 2 & $\begin{array}{l}\text { Same, } 250 \text { feet southeast of opening, entry } 5 \text {, } \\
51 \frac{1}{2} \text {-inch cut. }\end{array}$ & 7132 & A & $\begin{array}{l}1 \\
2 \\
3\end{array}$ & 2.2 & $\begin{array}{l}50.6 \\
51.7 \\
57.9\end{array}$ & $\begin{array}{l}36.7 \\
37.5 \\
42.0\end{array}$ & $\begin{array}{l}10.4 \\
10.7\end{array}$ & $\begin{array}{l}.99 \\
1.01 \\
1.13\end{array}$ & $\begin{array}{l}6.57 \\
6.47 \\
7.25\end{array}$ & $\begin{array}{l}72.01 \\
73.63 \\
82.45\end{array}$ & $\begin{array}{l}1.17 \\
1.20 \\
1.34\end{array}$ & $\begin{array}{l}8.80 \\
6.99 \\
7.83\end{array}$ & 1.3 & $\begin{array}{l}7,640 \\
7,810 \\
8,750\end{array}$ & $\begin{array}{l}13,750 \\
14,060 \\
15,730\end{array}$ \\
\hline 3 & $\begin{array}{l}\text { Lesley (East Point post office), Lesley mine, } \\
\text { Lesley bed, cannel coal. } \\
\text { KANE coUNTr, UTAB. }\end{array}$ & $\begin{array}{l}5437 \\
\ddots\end{array}$ & $\mathbf{A}$ & $\begin{array}{l}1 \\
2 \\
3\end{array}$ & 1.7 & $\begin{array}{r}50.7 \\
51.6 \\
.57 .0\end{array}$ & $\begin{array}{l}38.2 \\
38.8 \\
42.9\end{array}$ & $\begin{array}{l}9.3 \\
9.4\end{array}$ & $\begin{array}{l}1.02 \\
1.04 \\
1.15\end{array}$ & $\begin{array}{l}6.83 \\
6.75 \\
7.46\end{array}$ & $\begin{array}{l}73.25 \\
74.52 \\
82.31\end{array}$ & $\begin{array}{l}1.31 \\
1.33 \\
1.47\end{array}$ & $\begin{array}{l}8.28 \\
6.89 \\
7.61\end{array}$ & .4 & $\begin{array}{l}7,950 \\
8,050 \\
8,900\end{array}$ & $\begin{array}{l}14,250 \\
14,500 \\
16,010\end{array}$ \\
\hline 4 & $\begin{array}{l}\text { Glendale, } 13 \text { miles northwest of, NE. } 1 \text { sec. } 26 \text {, } \\
\text { T. } 39 \text { S., R. 9 W., on North Fork Virgin } \\
\text { River, Cannel King prospect, } 66 \text {-inch bench, } \\
\text { pher. }\end{array}$ & 5306 & B & $\begin{array}{l}1 \\
2 \\
3\end{array}$ & 15.7 & $\begin{array}{l}41.9 \\
49.7 \\
59.9\end{array}$ & $\begin{array}{l}28.0 \\
33.2 \\
40.0\end{array}$ & $\begin{array}{l}14.3 \\
17.0\end{array}$ & $\begin{array}{l}1.32 \\
1.57 \\
1.89\end{array}$ & $\begin{array}{r}6.11 \\
5.17 \\
6.23\end{array}$ & $\begin{array}{l}51.96 \\
61.67 \\
74.32\end{array}$ & $\begin{array}{l}1.16 \\
1.38 \\
1.66\end{array}$ & $\begin{array}{l}25.11 \\
13.19 \\
15.90\end{array}$ & 4.5 & $\begin{array}{l}5,280 \\
6,270 \\
7,555\end{array}$ & $\begin{array}{r}9,510 \\
11,280 \\
13,600\end{array}$ \\
\hline 5 & 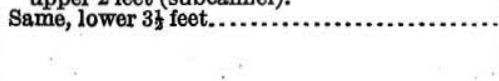 & 5308 & B & $\begin{array}{l}1 \\
2 \\
3\end{array}$ & 7.3 & $\begin{array}{l}46.9 \\
50.6 \\
67.6\end{array}$ & $\begin{array}{l}22.4 \\
24.2 \\
32.3\end{array}$ & $\begin{array}{l}23.2 \\
25.0\end{array}$ & $\begin{array}{l}1.61 \\
1.74 \\
2.32\end{array}$ & $\begin{array}{l}6.18 \\
5.79 \\
7.73\end{array}$ & $\begin{array}{l}51.88 \\
56.00 \\
74.75\end{array}$ & $\begin{array}{l}1.06 \\
1.14 \\
1.52\end{array}$ & $\begin{array}{l}16.03 \\
10.25 \\
13.68\end{array}$ & 1.1 & $\begin{array}{l}5,733 \\
6,210 \\
8,290\end{array}$ & $\begin{array}{l}10,360 \\
11,800 \\
14,920\end{array}$ \\
\hline
\end{tabular}

a Lord, N. W., and others. Analyses of coals: Bur. Mines Bull. 22, pp. 105, 194, 1913.

b A, Mine sample collected by an inspector of the Geological Survey; B, mine sample collected by a geologist of the Survey.

$c 1$, Sample as received; 2 , dried at temperature of $105^{\circ} \mathrm{C} . ; 3$, moisture and ash free. 
Additional ultimate analyses of cannel coal.

\begin{tabular}{|c|c|c|c|c|c|c|c|c|c|}
\hline $\begin{array}{l}\text { No. of } \\
\text { anal- } \\
\text { ysis. }\end{array}$ & Locality. & $\begin{array}{l}\text { Condi- } \\
\text { tion.a }\end{array}$ & Ash. & $\begin{array}{l}\text { Sul- } \\
\text { phur. }\end{array}$ & $\begin{array}{c}\text { Hydro- } \\
\text { gen. }\end{array}$ & $\begin{array}{l}\text { Car- } \\
\text { bon. }\end{array}$ & $\begin{array}{l}\text { Nitro- } \\
\text { gen. }\end{array}$ & $\begin{array}{l}\text { Oxy- } \\
\text { gen. }\end{array}$ & $\begin{array}{l}\text { Mois- } \\
\text { ture. }\end{array}$ \\
\hline 6 & $\begin{array}{l}\text { Boghead, Scotland } b \ldots . . . \\
\ldots \ldots \ldots\end{array}$ & $\begin{array}{r}18 \\
3\end{array}$ & 18.6 & 0.15 & & & 0.7 & 5.4 & \\
\hline 7 & Breckinridge, ky.b........ & $\begin{array}{r}0 \\
1 \mathbf{a} \\
3\end{array}$ & $14 . \ddot{8}$ & 2.4 & $\begin{array}{r}6.4 \\
7.8\end{array}$ & $\begin{array}{l}68.4 \\
68,3\end{array}$ & $\begin{aligned} 2.0 \\
2.7\end{aligned}$ & $\begin{array}{l}0.7 \\
7.3\end{array}$ & $\cdots \cdots$ \\
\hline $\begin{array}{r}8 \\
9 \\
10\end{array}$ & $\begin{array}{l}\text { Hiaddock, Owsiey County, } \mathrm{K} y . c \\
\text { Albertite, Nova Scotiad } \\
\text { English cannel, Nova Scotia } е . . .\end{array}$ & $\begin{array}{r}1 \mathrm{a} \\
\text { 1a } \\
\text { 1a }\end{array}$ & $\begin{array}{l}3.0 \\
.1 \\
2.4\end{array}$ & Tr. & $\begin{array}{l}6.1 \\
9.2 \\
5.7\end{array}$ & $\begin{array}{l}76.7 \\
85.4 \\
78.9\end{array}$ & $\begin{array}{l}13 \\
3.0\end{array}$ & $\begin{array}{l}7.0 \\
7.2\end{array}$ & i.2 \\
\hline 11 & 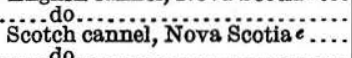 & $\begin{array}{r}3 \\
1 \mathrm{a} \\
\end{array}$ & 12.0 & 1.4 & $\begin{array}{r}5.9 \\
9.7\end{array}$ & $\begin{array}{l}81.9 \\
70.5\end{array}$ & 3 & $\begin{array}{c}12.1 \\
0\end{array}$ & $\dddot{3.2}$ \\
\hline 12 & wigan cannel, England ${ }_{f} \ldots . . . .$. & $\begin{array}{l}3 \\
3\end{array}$ & ( & $\begin{array}{l}1.6 \\
1.4\end{array}$ & $\begin{array}{l}11.5 \\
6.08\end{array}$ & $\begin{array}{l}83.2 \\
79.2\end{array}$ & $\begin{array}{l}3 \\
1.1\end{array}$ & $\begin{array}{l}5 \\
7.2\end{array}$ & an. \\
\hline
\end{tabular}

a 1a, Ass received, probsbly crudely air dried; 3 , moisture and ash free.

$b$ Peter, Robert, Second chemical report of the ores, rocks; soils, coals, etc., of Kentucky: Kentucky Geol. Survey Second Rept., p. 213, 1857.

c Idem, p. 255.

$d$ Gesner, Abraham, Practical treatise on coal, petroleum, and other distilled oils, 2d ed., p: 23, New York, Baillière Bros., 1865.

eOwen, D. D., Kentucky Geol. Survey Second Rept., p. 57, 1857.

$f$ Idem, p. 59.

Analyses of Arkansas Camden coal (typical of brown subcannel).

\begin{tabular}{|c|c|c|c|c|c|c|c|c|c|}
\hline $\begin{array}{c}\text { No.of } \\
\text { anal- } \\
\text { ysis. }\end{array}$ & Locality. & Analyst. & $\begin{array}{c}\text { Condi- } \\
\text { tion. } a\end{array}$ & $\begin{array}{l}\text { Mois- } \\
\text { ture. }\end{array}$ & $\begin{array}{l}\text { Vola- } \\
\text { tile } \\
\text { mat- } \\
\text { ter. }\end{array}$ & $\begin{array}{l}\text { Fixed } \\
\text { car- } \\
\text { bon. }\end{array}$ & Ash. & $\begin{array}{l}\text { Sul- } \\
\text { phur. }\end{array}$ & $\begin{array}{l}\text { Thick- } \\
\text { ness of } \\
\text { bed. }\end{array}$ \\
\hline $\begin{array}{l}13 \\
14 \\
15 \\
16 \\
17 \\
18\end{array}$ & 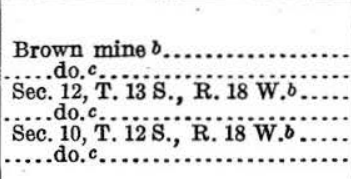 & 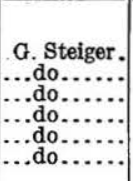 & $\begin{array}{l}\mathbf{A} \\
\mathbf{B} \\
\mathbf{A} \\
\mathbf{B} \\
\mathbf{A} \\
\mathbf{B}\end{array}$ & $\begin{array}{r}38.7 \\
11.2 \\
38.0 \\
11.0 \\
32.7 \\
9.5\end{array}$ & $\begin{array}{l}36.9 \\
44.0 \\
37.1 \\
47.9 \\
32.9 \\
46.2\end{array}$ & $\begin{array}{l}16.9 \\
33.6 \\
79.9 \\
32.8 \\
22.3 \\
29.4\end{array}$ & \begin{tabular}{r|}
7.5 \\
11.0 \\
5.8 \\
8.2 \\
11.3 \\
14.4
\end{tabular} & $\begin{array}{r}0.5 \\
.7 \\
.4 \\
.5 \\
.4 \\
.6\end{array}$ & 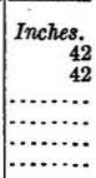 \\
\hline
\end{tabular}

a A, Analysis of fresh sample; B, analysis of sample after long drying.

$b$ Taff, J. A., Preliminary report on the Camden coal field of southwestern Arkansas: U. S. Geol. Survey Twenty-first Ann. Rept., pt. 2, p. 326, 1900.

c Idem, p. 327.

Proximate analyses of cannel coal.

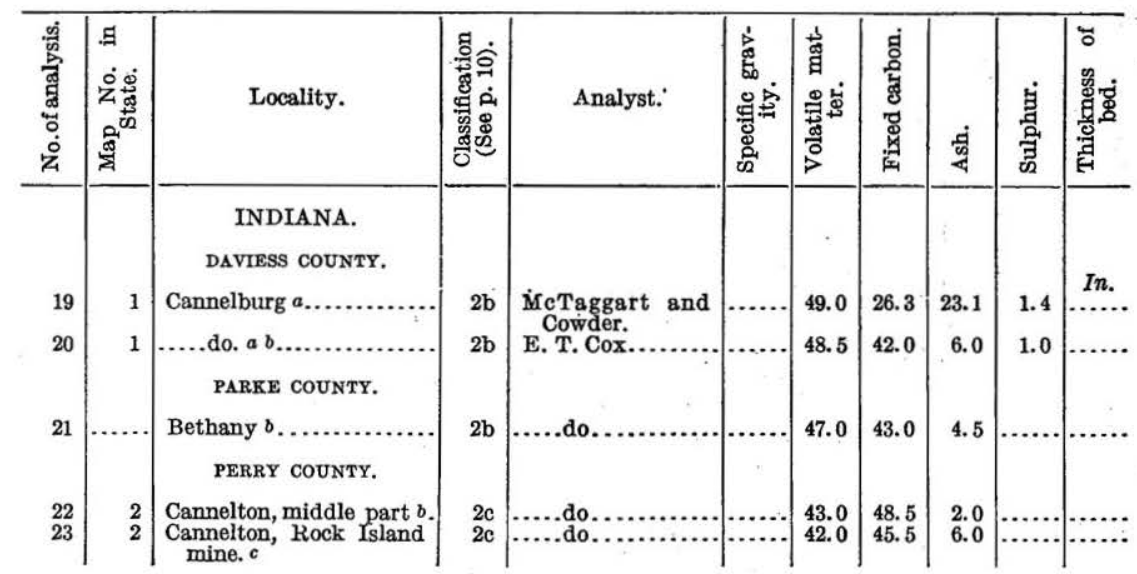

a Ashley, G. H., The coal deposits of Indiana: Inđiana Dept. Geology and Nat. Res. Twenty-third Ann. Rept., pp. 988, 989, 1570, 1899 .

box, E. T., Indiana Geol. Survey Third and Fourth Ann. Repts., p. 187, 1872.

c Idem, p. 183 . 
COMPOSITION.

Proximate analyses of cannel coal-Continued.

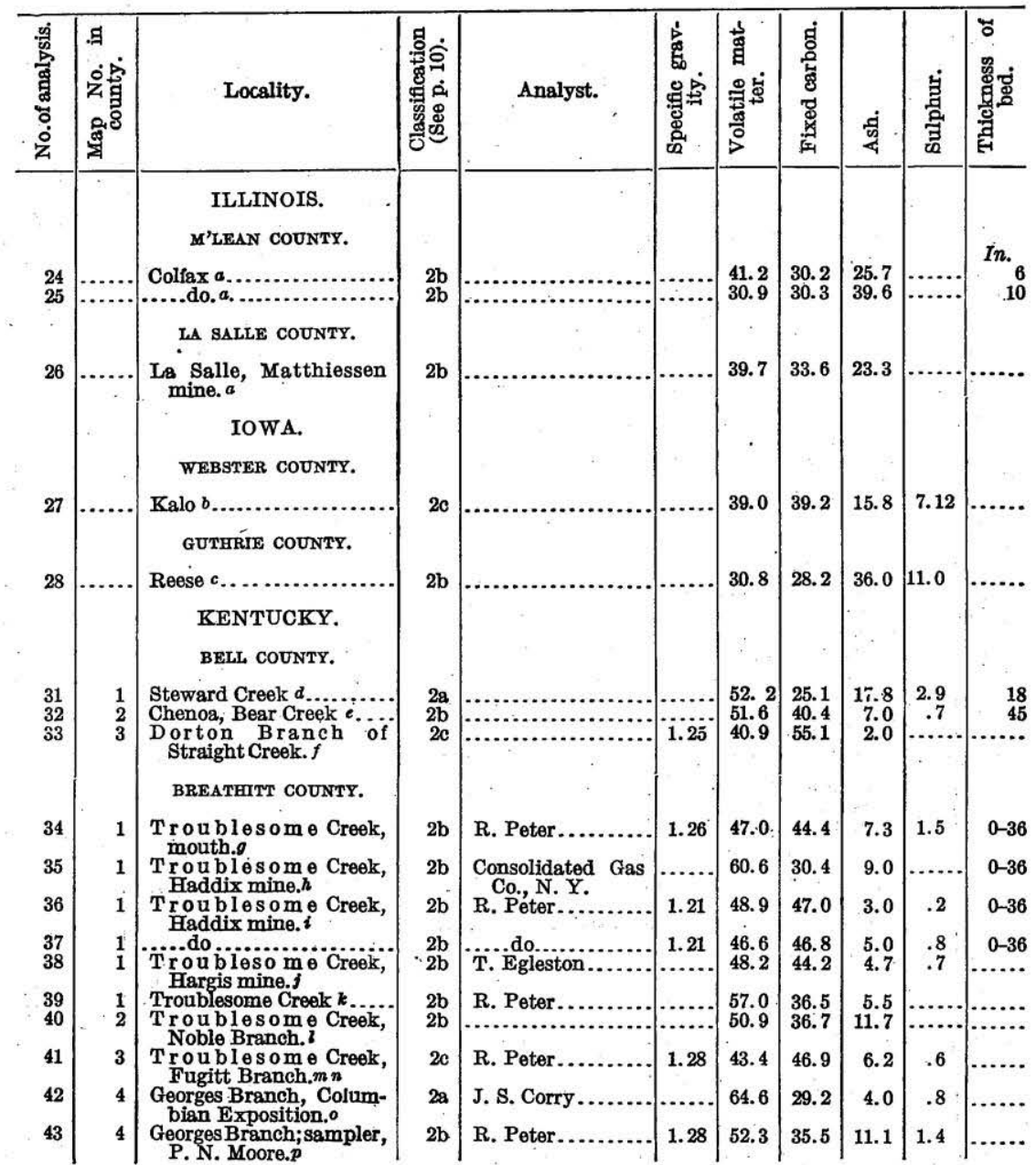

$a$ Grout, F. F., Cannel coal in northern Mlinois: Mlinois State Geol. Survey Bull, 4, p. 198, 1907.

b Keyes, C. R., Coal deposits of Iowa: Iowa Geol. Survey, vol. 2, p. 509, 1894.

$c$ Idem, p. 505 .

d Hendrie, Charles, Some Kentucky cannels: Kentucky Inspector of Mines Tenth Ann. Rept.,

e Crandall, A. R., and Sullivan, G. M., Report on the coal field adjacent to Pineville Gap in Bell and Knox counties: Kentucky Geol. Survey Bull. 14, p. 20, 1912.

$f$ Owen, D. D., Kentucky Geol. Survey Rept. for 1854 and 1855, p. 224, 1856.

$g$ Peter, Robert, Chemical analyses: Kentucky Geol. Survey Rept. A, pt. 1, p. 219, 1884.

$h$ Hendrie, Charles, Some Kentucky cannels: Kentucky Inspector of Mines Tenth Ann. Rept.,

i Hodge, J. M., Report on the coals of the three forks of the Kentucky River: Kentucky Geol. Survey

$j$ Hodge, J. M., Preliminary report on the geology of parts of Letcher, Harlan, Leslie, Perry, and Breathitt counties, p. 52a, Kentucky Geol. Survey, 1887.

$k$ Owen, D. D., Kentucky Geol. Survey Rept. for 1854 and 1855, p. 212, 1856.

$l$ Hodge, J. M., Report on the coals of the three forks of the Kentucky River: Kentucky Geol. Survey Bull. 11, p. 28, 1910.

$m$ Peter, Robert, op. cit., p. 221.

$n$ Hodge, J. M., Report on the coals of the three forks of the Kentucky River: Kentucky Geol. Survey Bull. 11, p. 45, 1910.

o Hendrie, Charles, op. cit., p. 137.

$p$ Peter, Robert, op. cit., p. 220. 
Proximate analyses of cannel coal-Continued.

\begin{tabular}{|c|c|c|c|c|c|c|c|c|c|c|}
\hline 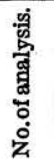 & 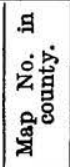 & Locality. & 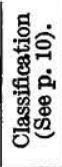 & Analyst. & 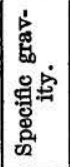 & 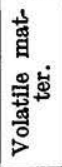 & 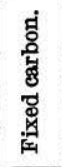 & हुं & 总 & 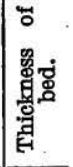 \\
\hline & & $\begin{array}{l}\text { KENTUCKY-Contd. } \\
\text { BREATHITTCOUNTY-con. }\end{array}$ & & & & & & & & \\
\hline 44 & 4 & $\begin{array}{l}\text { Georges Branch; sampler, } \\
\text { C. Hendrie. } a b\end{array}$ & $2 b$ & R. Peter & & 58.0 & 34.0 & 7.4 & 1.0 & \\
\hline 45 & 4 & Georges Branch c ......... & $2 \mathrm{~b}$ & Consolidated Gas & & 61.9 & 33.7 & 4.4 & & \\
\hline 46 & 4 & $\begin{array}{l}\text { GeorgesBranch; sampler, } \\
\text { T. Egleston.db }\end{array}$ & $2 b$ & Co., N. $x$. & & 45.4 & 40.1 & 12.8 & 1.7 & \\
\hline 47 & 4 & $\begin{array}{l}\text { Georges Branch, carload } \\
\text { lot.e }\end{array}$ & $2 \mathrm{~b}$ & & & 54.0 & 34.4 & $\cdot 10.9$ & & \\
\hline 48 & 5 & $\begin{array}{l}\text { North Fork Kentucky } \\
\text { River, Wolf Creek.b } f\end{array}$ & $2 \mathrm{~b}$ & & & 41.7 & 33.3 & 24.2 & & \\
\hline 49 & 6 & $\begin{array}{l}\text { Quicksand Creek, Round- } \\
\text { bottom.g }\end{array}$ & $2 \mathrm{~b}$ & & 1.27 & 44.0 & 39.9 & 15.4 & .4 & 37 \\
\hline 50 & 7 & $\underset{\text { Creek. } h}{\text { Nichols Fork, Frozen }}$ & $2 \mathrm{~b}$ & R. Peter & 1.36 & 58.8 & 35.3 & 4.7 & & \\
\hline $\begin{array}{l}51 \\
52\end{array}$ & $\begin{array}{r}7 \\
6-9\end{array}$ & Quicksand C̈reek $d . . . . . . .$. & $\begin{array}{l}2 \mathrm{~b} \\
2 \mathrm{~b}\end{array}$ & T. Eglest & $\begin{array}{l}1.36 \\
\cdots\end{array}$ & $\begin{array}{l}43.2 \\
44.2\end{array}$ & $\begin{array}{l}33.8 \\
43.4\end{array}$ & $\begin{array}{r}21.4 \\
9.8\end{array}$ & $\begin{array}{l}2.5 \\
1.2\end{array}$ & \\
\hline 53 & $10-12$ & $\begin{array}{l}\text { Quicksand Creek; sam- } \\
\text { pler, J. R. Proctor.j }\end{array}$ & $2 c$ & R. Peter & 1.32 & 43.1 & 43.3 & 11.4 & 4.6 & \\
\hline 54 & 12 & $\begin{array}{l}\text { South Fork Quicksand } \\
\text { Creek, lower mine.d }\end{array}$ & $2 c$ & T. Egles & & 39.4 & 48.2 & 9.5 & 1.2 & \\
\hline $54 \mathrm{a}$ & 12 & $\begin{array}{l}\text { South Fork Quicksand } \\
\text { Creek, upper mine.d }\end{array}$ & $2 c$ & go & & 45.6 & 47.1 & 4.9 & 1.7 & \\
\hline 55 & 13 & Jackson, near $k . . . \ldots \ldots$. & $2 \mathrm{~b}$ & R. Peter........... & 1.21 & 56.7 & 38.1 & 4.9 & 1.5 & \\
\hline 56 & ${ }^{\bullet} 13$ & 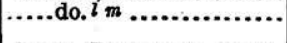 & $2 a$ & $\begin{array}{l}\text { Consolidated Gas } \\
\text { Co., N. Y. }\end{array}$ & $\cdots$ & 68.0 & 28.2 & 3.8 & . & 16 \\
\hline 57 & 14 & $\begin{array}{l}\text { Stacy Branch of South } \\
\text { Quicksand Creek. } d n\end{array}$ & $2 a$ & $T-1$ & & 66.2 & 29.7 & 3.6 & & \\
\hline $\begin{array}{l}58 \\
58 \mathrm{a}\end{array}$ & 14 & 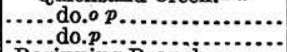 & $\begin{array}{l}2 \mathrm{a} \\
2 \mathrm{a}\end{array}$ & $\begin{array}{l}\text { R. Peter. } \\
\text { T. Eglesto }\end{array}$ & & $\begin{array}{l}66.2 \\
62.4\end{array}$ & $\begin{array}{l}29.7 \\
31.4\end{array}$ & $\begin{array}{l}3.6 \\
6.0\end{array}$ & & 21 \\
\hline $\begin{array}{l}59 \\
60\end{array}$ & $\begin{array}{l}20 \\
22\end{array}$ & $\begin{array}{l}\text { Beginning Branch } q . . . \\
\text { Cockerill Fork } r\end{array}$ & $\begin{array}{l}2 \mathrm{c} \\
2 \mathrm{~b}\end{array}$ & R. Peter. & 1.27 & $\begin{array}{l}41.1 \\
50.6\end{array}$ & $\begin{array}{l}46.7 \\
36.7\end{array}$ & $\begin{array}{l}11.2 \\
11.3\end{array}$ & 1.2 & \\
\hline 61 & 19 & John Little Branch q..... & $2 \mathrm{~b}$ & $\cdots \ldots$ & $\because i .17$ & & 39.5 & 5.3 & .7 & \\
\hline & & CARTER COUNTY. & & & & & & & & \\
\hline 62 & 1 & $\underset{\text { Branch. }}{\text { Stinson }}$ & $2 a$ & R. Peter.... & 1.14 & 64.1 & 27.0 & 7.9 & 2.8 & \\
\hline 63 & 1 & $\begin{array}{c}\text { Stinson Creek, Stinson } \\
\text { mine.t }\end{array}$ & 28 & do & 1.20 & 66.3 & 28.3 & 4.8 & 1.3 & \\
\hline $\begin{array}{l}64 \\
65 \\
66\end{array}$ & $\begin{array}{l}1 \\
4 \\
5\end{array}$ & $\begin{array}{l}\text { Stinson Creek } u \ldots \ldots \ldots \ldots \\
\text { Barrett Creek } v \ldots \ldots \ldots . . . \\
\text { Little Sandy River, } 6 \\
\text { miles south of Leon.w }\end{array}$ & $\begin{array}{l}2 \mathrm{~b} \\
2 \mathrm{c} \\
2 \mathrm{a}\end{array}$ & (a.do... & $\begin{array}{l}1.21 \\
1.44 \\
\cdots\end{array}$ & $\begin{array}{l}57.0 \\
33.5 \\
61.1\end{array}$ & $\begin{array}{l}34.5 \\
42.7 \\
30.3\end{array}$ & $\begin{array}{r}6.5 \\
19.8 \\
7.6\end{array}$ & $\ddot{7.9}$ & \\
\hline 67 & 5 & 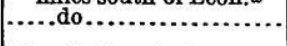 & $2 \mathrm{~b}$ & Consolidated Gas & & 58.7 & 34.5 & 5.9 & & \\
\hline 68 & & $\begin{array}{l}\text { Crawford cannel, near } \\
\text { Grayson. } \\
\text { clay coUNTY. }\end{array}$ & $2 \mathrm{~b}$ & R. Peter..... & 1. 21 & 57.0 & 34.5 & 6.5 & & \\
\hline $\begin{array}{l}69 \\
70\end{array}$ & $\begin{array}{l}\mathbf{2} \\
\mathbf{3}\end{array}$ & $\begin{array}{l}\text { Toms Branch } q . \ldots . \\
\text { Beech Creek } q . \ldots . . .\end{array}$ & $\begin{array}{r}2 \mathrm{~b} \\
2 \mathrm{c}\end{array}$ & R. Peter... & 1. 16 & $\begin{array}{l}44.1 \\
32.3\end{array}$ & $\begin{array}{l}43.7 \\
35.2\end{array}$ & $\begin{array}{l}11.8 \\
32.0\end{array}$ & $\begin{array}{l}1.2 \\
6.0\end{array}$ & 5 \\
\hline
\end{tabular}

a Hendrie, Charles, op. cit., p. 135.

$b$ Hodge, J. M., Kentucky Geol. Survey Bull. 11, p. 71, 1910.

c Hendrie, Charles, op. cit., p. 136.

d Hodge, J. M., Preliminary report on the geology of parts of Letcher, Harlan, Leslie, Perry, and Breathitt counties, p. 52a, Kentucky Geol. Survey, 1887.

¿ Crandall, A. R., Coals of the Licking Valley region: Kentucky Geol. Survey Bull. 10, p. 65, 1910.

$f$ Hodge, J. M., Kentucky Geol. Survey Bull. 11, pp. 65, 71, 1910.

g Owen, D. D., Kentucky Geol. Survey Fourth Rept., p. 95, 1861.

$h$ Crandall, A. R., op. cit., p. 64 .

i Peter, Robert, Chemical analyses: Kentucky Geol. Survey Rept. A, pt. 1, p: $219,1884$.

j Idem, p. 220.

k Owen, D. D., Kentucky Geol. Survey Bull. 10, p. 96, 1861.

$l$ Hendrie, Charles, op. cit., p. 143.

$m$ Fohs, F. H., Kentucky Geol. Survey Bull. 18, p. 35, 1912.

$n$ Idem, p. 30 .

o Hendrie, Charles, op. cit., p. 142.

$p$ Fohs, F. H., op. cit., p. 77 .

$q$ Hodge, J. M., Preliminary report on the geology of the lower North Fork, Middle and South forks

Kentucky River, Kentucky Geol. Survey, 1887.

$r$ Hendrie, Charles, op. cit., p. 139.

: Owen, D. D., Kentucky Geol. Survey Fourth Rept., p. 114, 1861.

$t$ Idem, p. 111.

u Owen, D. D., Kentucky Geol. Survey Rept. for 1854 and 1855, p. 201, 1856.

- Idem, p. 270.

w Hendrie, Charles, op cit, p. 147.

$x$ Owen, D. D., Kentucky Geol. Survey Rept. for 1854 and 1855, p. 69, 1856. 
Proximate analyses of cannel coal-Continued.

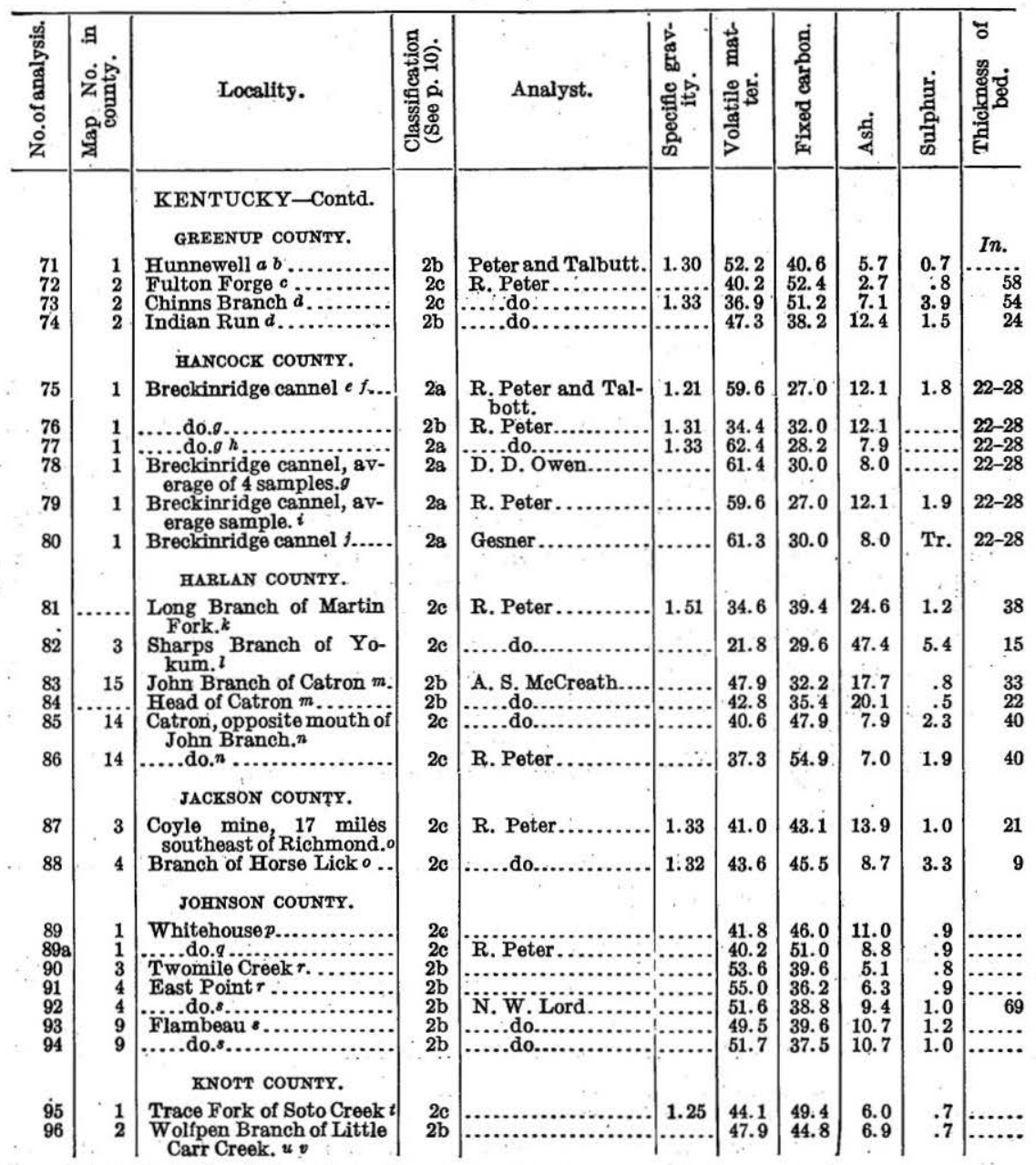

a Peter, Robert, Chemical analyses: Kentucky Geol. Survey Rept. A, pt. 1, p, 167, 1884.

$b$ Norwood, C. J., A report on the reconnaissance of a part of the Breckinridge cannel-coal district: Ken-

tucky Geol. Survey Repts. on western coal field, D, p. 217 [25], 1884.

d Crandall, A. R., Report on the Chinns Branch cannel-coal district: Kentucky Geol. Survey Repts. on eastern coal field, C, p. 6 [200], 1884

e Crandall, A. R., Coals of the Licking Valley region: Kentucky Geol. Survey Bull. 10, p. 65, 1910.

$f$ Peter, Robert, op. cit., p. 83.

o Norwood, C. J., Kentucky Inspector of Mines Tenth Ann. Rept., p. 13, 1894.

i Idem, p. 177 .

1 Gesner, Abraham, Practical treatise on coal, petroleum, and other distilled oils, 2d ed., p. 51, New York, Baillière Bros., 1865.

$k$ Peter, Robert, op. cit., p. 265

$l$ Hodge, J. M. The upper Cumberland coal field: Kentucky Geol. Survey Bull. 13, p. 51, 1912.

$m$ Ashley, G. H, and Glenn, L. C., Geology and mineral resources of part of Cumberland Gap coal field, Ky.: U. S. Geol. Survey Prof. Paper 49, p. 201, 1906.

$n$ Idem, p. 198.

- Peter, Robert, op. cit., p. 273

$p$ Crandall, A. R., The coals of the Big Sandy Valley: Kentucky Geol. Survey Bull. 4, p. 28, 1905.

$q$ MacFarlane, Graham, Notes on American cannel coal: Am. Inst. Min. Eng. Trans., vol. 18, p. 438, 1890. $r$ Crandall, A. R., op. cit., p. 35.

- Lord, N.' W., and others, Analyses of coals in the United States: Bur. Mines Bull. 22, pt. 1, p. $105,1913$. $t$ Hodge, J. M., Report on the coals of the three forks of the Kentucky River: Kentucky Geol. Survey Bull. 11, p. 93, 1910.

$u$ Crandall, A. R., Report on the Pound Gap region, p. 29, Kentucky Geol. Survey, 1887.

- Hodge, J. M., op. cit., p. 107. 
Proximate analyses of cannel coal-Continued.

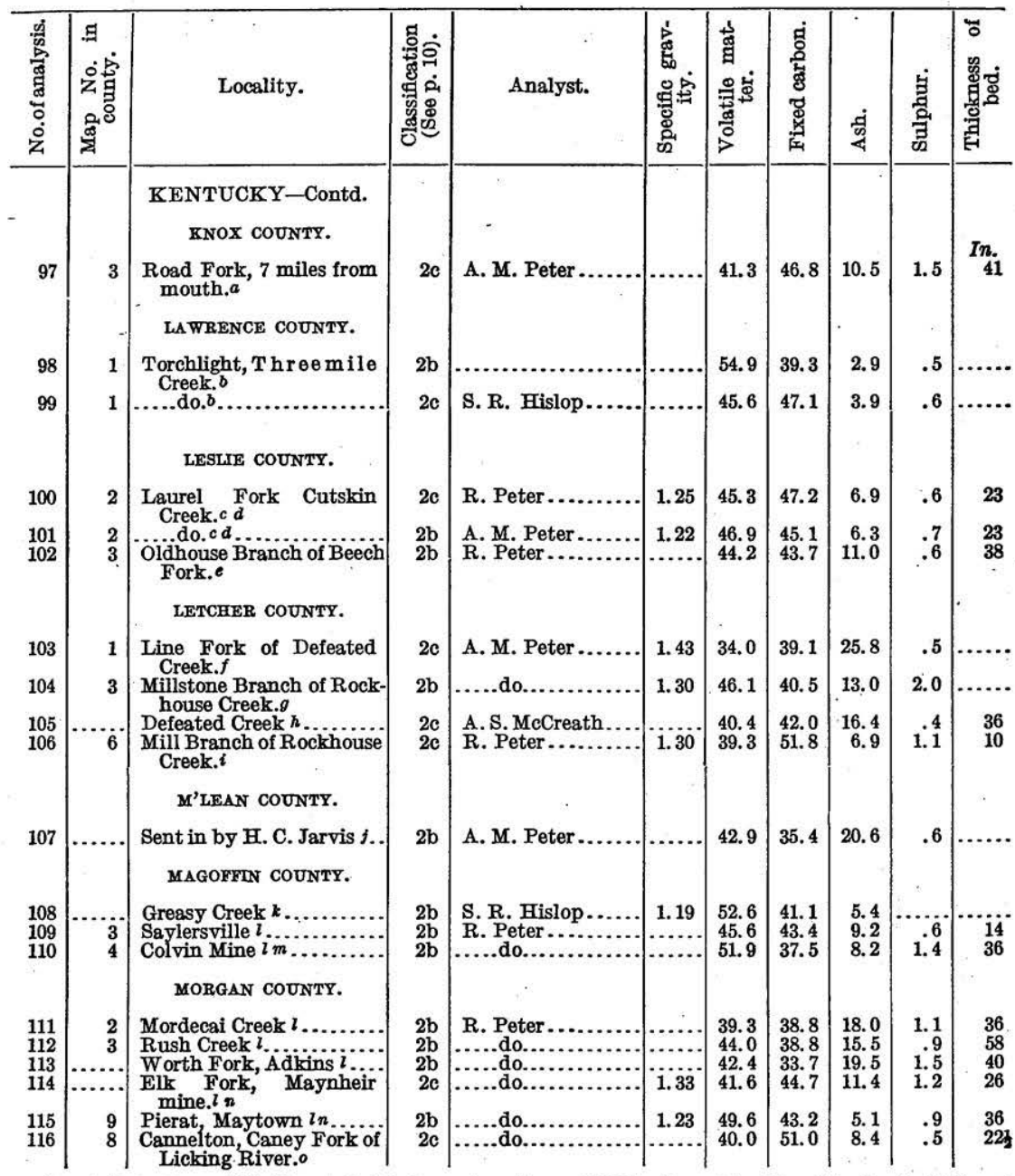

$a$ Crandall, A. R., and Sullivan, G. M., Report on the coal field adjacent to Pineville Gap in Bell and

Knox counties: Kentucky Geol. Survey Bull. 14, p. 125, 1912.

$b$ Phalen, W. C., Economic geology of the Kenova quadrangle: U. S. Geol. Survey Bull. 349, p. $59,1908$. $c$ Hodge,J. M., Preliminary report on the geology of parts of Letcher, Harlan, Leslie, Perry, and Breathitt counties, p. 48, Kentucky Geol. Survey, 1887.

$d$ Hodge, J. M., Report on the coals of the three forks of the Kentucky River: Kentucky Geol. Survey Bull. 11, p. 196, 1910

e Hodge, J. M., Kentucky Geol. Survey Bull. 11, p. 222, 1910.

$f$ Idem, p. 127.

$g$ Idem, p. 135.

$h$ Hendrie, Charles, Some Kentucky cannels: Kentucky Inspector of Mines Tenth Ann. Rept., p. 144, 1894

$i$ Ḣodge, J. M., Kentucky Geol. Survey Bull. 11, p. 146, 1910.

$j$ Stone, G. W., Kentucky Inspector of Mines Sixteenth Ann. Rept., p. 115, 1900.

$\boldsymbol{k}$ Idem, prandall, A. R., Preliminary report on the geology of Morgan, Johnson, Magoffin, and Floyd counties:

Kentucky Geol. Survey, 2d ser., vol. 6, pt. 5, p. 15 [1880].

$m$ Crandall, A. R., Coals of the Licking Valley region: Kentucky Geol. Survey Bull. 10, p. 18, 1910.

$n$ Peter, Robert, Chemical analyses: Kentucky Geol. Survey Rept. A, pt. 1, p. 296, 1884.

o Crandall, A. R., Kentucky Geol. Survey Bull. 10, p. 14, 1910. 
Proximate analyses of cannel coal-Continued.

\begin{tabular}{|c|c|c|c|c|c|c|c|c|c|c|}
\hline 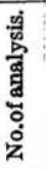 & 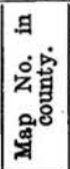 & Locality. & 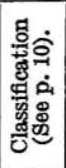 & Analyst. & 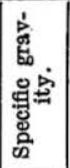 & 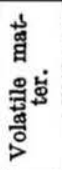 & 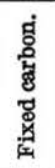 & वृं & 岂 & 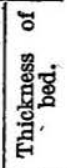 \\
\hline & & $\begin{array}{l}\text { KENTUCKY-Contd. } \\
\text { MORGAN COUNTY-con. }\end{array}$ & & & & & & & & \\
\hline 117 & 13 & $\begin{array}{l}\text { Brush Fork Caney Creek } \\
\text { (Lykins)a. }\end{array}$ & $2 c$ & R. Peter........... & & 41.0 & 45.1 & 12.0 & 0.8 & 5 \\
\hline 118 & .... & $\begin{array}{l}\text { Sugar Camp Branch } \\
\text { Caney Creek.a }\end{array}$ & $2 c$ & ....do......... & & 41.6 & 49.1 & 8.5 & 1.6 & 251 \\
\hline 119 & & Old $\underset{\text { Caney Creek. }}{\text { H }}$ ranch & $2 c$ & ....do.. & & 40.8 & 48.8 & 8.6 & .8 & 24 \\
\hline 120 & 6 & $\begin{array}{l}\text { Spring Branch Caney } \\
\text { Creek (drift 11).a }\end{array}$ & $2 c$ & do & & 40.4 & 48.8 & 9 & 2.7 & 281 \\
\hline 121 & .. & $\begin{array}{c}\text { Johnson Branch Prater } \\
\text { Fork Caney Creek.a }\end{array}$ & $2 c$ & ....do.. & & 40.6 & 50.2 & 7 & 1.2 & 21 \\
\hline 122 & & $\begin{array}{l}\text { Sugar Camp Branch } \\
\text { Caney Creek (drift 1).a }\end{array}$ & 20 & ...do. & & 40.7 & 51.2 & 6 & .7 & $\ldots$ \\
\hline 123 & & Caney Creek (drillings) $a$ & $2 c$ & .....do... & & 37.9 & 49.6 & 10 & 1.0 & 29 \\
\hline 124 & & $\begin{array}{l}\text { Benton Branch Yearling } \\
\text { Branch.a } \\
\text { owsLeY coUNTY. }\end{array}$ & $2 \mathrm{~b}$ & d & & 52.3 & 36.4 & 10 & & \\
\hline 125 & & $\begin{array}{l}\text { South Fork Kentucky } \\
\text { River, } 4 \text { miles above } \\
\text { Booneville.b }\end{array}$ & $2 b$ & R. Peter.......... & 1.16 & 59.7 & 32.3 & 7.4 & ....... & \\
\hline 126 & & $\begin{array}{l}\text { South Fork Kentucky } \\
\text { River, Merrill mine.c }\end{array}$ & $2 \mathrm{~b}$ & ...do............. & & 47.6 & 46.3 & 5.4 & ....... & $\ldots . .$. \\
\hline 127 & & $\begin{array}{l}\text { South Fork Kentucky } \\
\text { River, Reynolds mine.d }\end{array}$ & $2 \mathrm{~b}$ & ....do.. & & 55.0 & 34.7 & 9.7 & $\cdots$ & - \\
\hline 128 & & $\begin{array}{l}\text { South Fork Kentucky } \\
\text { River.e }\end{array}$ & $2 \mathrm{~b}$ & $\begin{array}{l}\text { Consolidated Gas } \\
\text { Co., N. Y. }\end{array}$ & & 52.6 & 43.6 & 3.8 & & \\
\hline $\begin{array}{l}129 \\
130\end{array}$ & 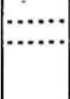 & $\begin{array}{l}\text { Haddock, between South } \\
\text { and Middle Fork Ken- } \\
\text { tucky River.f }\end{array}$ & $\begin{array}{l}2 \mathrm{~b} \\
2 \mathrm{~b}\end{array}$ & 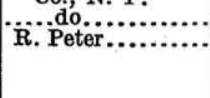 & & $\begin{array}{l}53.3 \\
48.9\end{array}$ & $\begin{array}{l}43.2 \\
47.0\end{array}$ & $\begin{array}{l}3.5 \\
3.0\end{array}$ & $\cdots$ & $\cdots$ \\
\hline & & PERRY COUNTX. & & & & & & & & \\
\hline 131 & 1 & Lots Creek $g$............... & $2 c$ & R. Peter.......... & 1.25 & 44.1 & 49.4 & 6.0 & .7 & 22 \\
\hline 132 & $\ldots$ & $\begin{array}{l}\text { Middle Fork, below Rush } \\
\text { Branch. } h \\
\text { PIKE coưNTY. }\end{array}$ & $2 c$ & & & & & & & \\
\hline 133 & 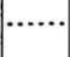 & $\underset{\text { Creek. } i}{\text { Beark }}$ Robinson & $2 c$ & R. Peter.......... & 1.29 & 43.4 & 46.3 & 8.3 & .6 & 33 \\
\hline 134 & $\cdots$ & $\begin{array}{l}\text { WHITLEY COUNTY. } \\
\text { Patterson Creek, Polly }\end{array}$ & $2 c$ & R. Peter.......... & ........ & 39.7 & 55.0 & 3.0 & .8 & 52 \\
\hline 135 & - & $\begin{array}{l}\text { Patterson Creek, Polly } \\
\text { mine, cannel only. } k\end{array}$ & $2 c$ & A. S. McCreath.... & & 47.1 & 52.2 & 1.2 & 1.1 & 31 \\
\hline $\begin{array}{l}136 \\
137 \\
138\end{array}$ & .... & $\begin{array}{l}\text { Patterson Creek, head of } l \text {. } \\
\text { Little Caney } f \ldots \ldots \ldots \ldots \\
\text { Halsey } m\end{array}$ & $\begin{array}{r}2 c \\
2 c \\
2 c\end{array}$ & $\begin{array}{l}\text { H. M. Curry ........ } \\
\text { R. Peter } \ldots . . . . . . \\
\text { Perkins \& Co.... }\end{array}$ & & $\begin{array}{l}43.9 \\
43.0 \\
48.0\end{array}$ & $\begin{array}{l}54.8 \\
48.8 \\
49.5\end{array}$ & $\begin{array}{l}1.2 \\
7.2 \\
2.5\end{array}$ & $\begin{array}{r}.6 \\
1.2\end{array}$ & 24-31 \\
\hline
\end{tabular}

a Crandall, A. R. Coals of the Licking Valley region: Kentucky Geol. Survey Bull. 10, p. 14, 1910.

b Peter, Robert, Chemical analyses: Kentucky Geol. Survey Rept. A. pt. 1; p. 315, 1884.

c Hendrie, Charles, Some Kentucky cannels: Kentucky Inspector of Mines Tenth Ann. Rept., p. 144, 1894.

d Idem, p. 143.

f Idem, p. 145. . Kentucky Geol. Survey Rept. for 1854 and 1855, p. $355,1856$.

$g$ Hodge, J. M., Preliminary report on the geology of parts of Letcher, Harlan, Leslie, Perry, and Breathitt counties, p. 48, Kentucky Geol. Survey, 1887.

$h$ Hodge, J. M., Preliminary report on the geology of the lower North Fork, Middle and South forks Kentucky River, p. 96, Kentucky Geol. Survey, 1887.

i Crandall, A. R., Report on the Pound Gap region, p. 29, Kentucky Geol. Survey, 1887.

$j$ Crandall, A. R., Report on the geology of Whitley County and a part of Pulaski, p. 38, Kentucky Geol. Survey, 1889 .

$\boldsymbol{k}$ Hendrie, Charles, op. cit., p. 148.

$l$ Idem, p. 147.

m Stone, G. W., Kentucky Inspector of Mines Sixteenth Ann. Rept., p. 115, 1900. 
Proximate analyses of cannel coal-Continued.

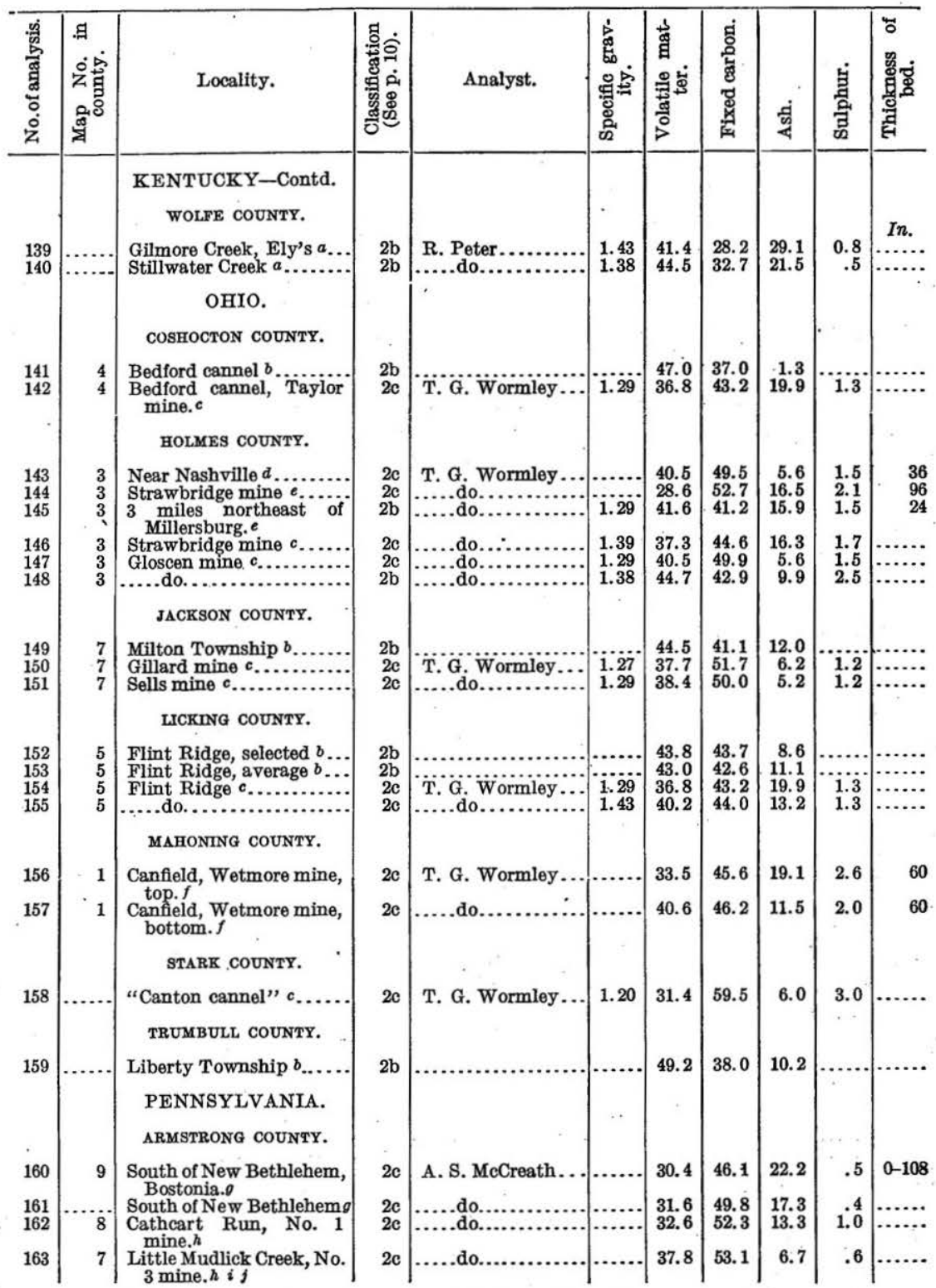

$a$ Peter, Robert, Chemical analyses: Kentucky Geol. Survey Rept. A, pt. 1, p. 328, 1884.

$b$ Ashley, G. H., Cannel coal in the United States: Min. World, vol. 23, p. 382, Oct. 7, 1905.

c Newberry, J. S., Ohio Geol. Survey Rept. Progress for 1870, p. 420, 1871.

d Idem, p. 33 .

d Idem, p. 33.
e Idem, p. 31.

I Idem, p. 31 .

$g$ Platt, Franklin, Report of progress in the Clearfield and Jefferson district: Pennsylvanis Second Geol. Survey Rept. H, p. 240,1875.

$h$ Platt, W. G., Report of progress in Armstrong County: Pennsylvania Second Geol. Survey Rept. H5, p. 180,1880 .

p. Butts, Charles, Economic geology of the Kittanning and Rural Valley quadrangles, Pa.: U. S. Geol.

Survey Bull. 279, p. 99, 1906 . Second Geol. Survey Rept. M3, p. 57, 1881. 
Proximate analyses of cannel coal-Continued.

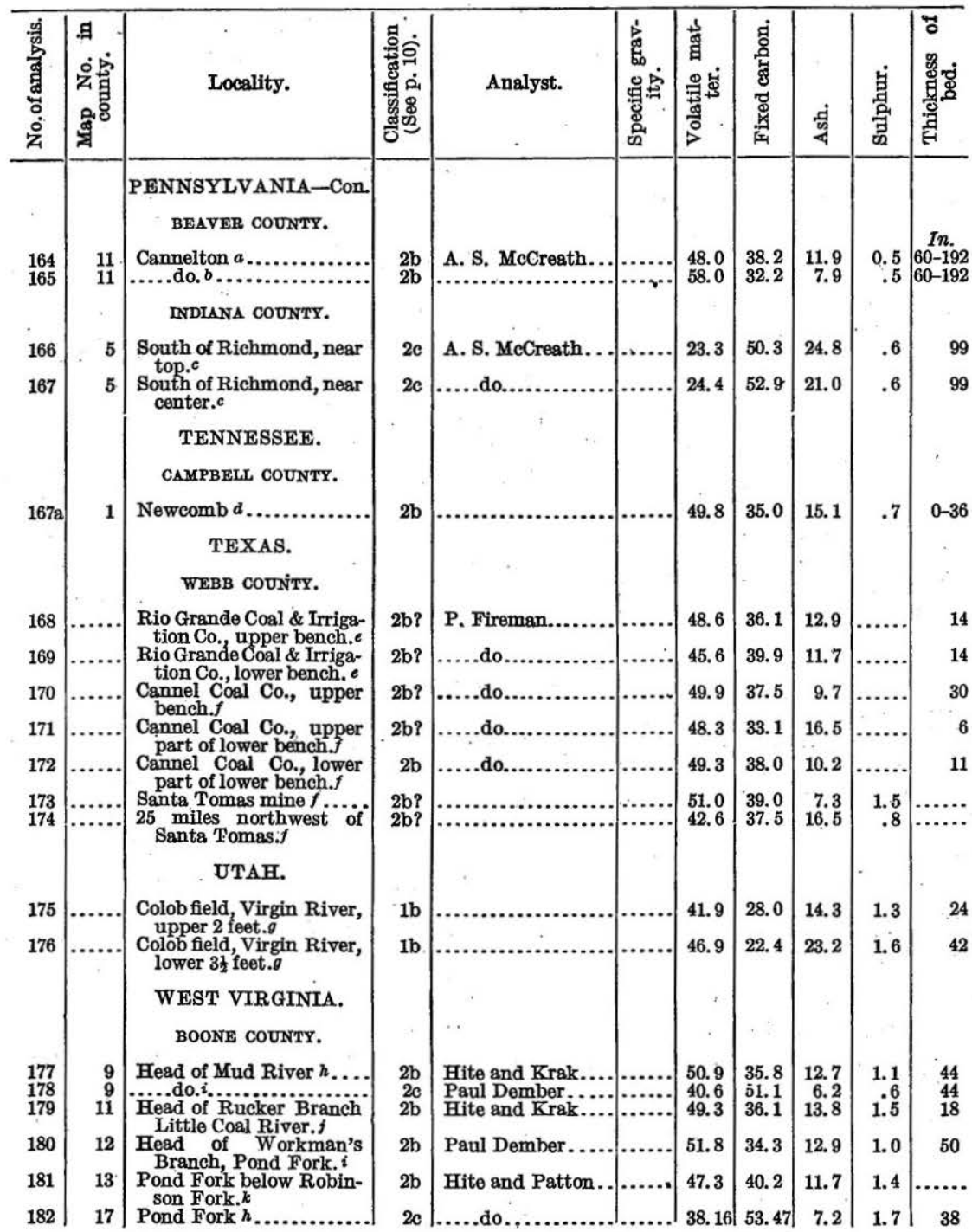

a McCreath, A. S., Second report of progress on the laboratory of the Survey at Harrisburg: Pennsylvania Second Geol. Survey Rept. M2, p. 54, 1879.

b Mansfield, I. F., Fire clays, coals, and titles of the cannel-coal tract at Cannelton, Beaver County, Pa., p. $9,1905$.

c Platt, W. G., Report of progress in Indians County: Pennsylvania Second Geol. Survey Rept: H4, p. $230,1878$.

d MacFarlane, Graham, Notes on American cannel coal: Am. Inst. Min. Eng. Trans., vol. 18, p. 438, 1890.

$e$ Vaughan, T. W., Reconnaissance in the Rio Grande coal fields of Texas: U. S. Geol. Survey Bull. 164, p. 64,1900 .

$f$ Idem, p. 65.

g Richardson, G. B., The Harmony, Colob, and Kanab coal fields, southern Utah: U. S. Geol. Survey Bull. 341, p. $397,1900$.

h Krebs, C. E., and Teets, D. D., Boone County: West Virginia Geol. Survey County Repts., p. 575, 1915.

i Idem, p. 324 .

j Idem, p. 576 .

$k$ White, I. C., Supplementary coal report: West Virginia Geol. Survey, vol, 2 (A), p. $399,1908$. 
Proximate analyses of cannel coal-Continued.

\begin{tabular}{|c|c|c|c|c|c|c|c|c|c|c|}
\hline 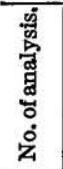 & 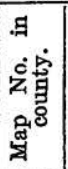 & Locality. & 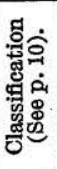 & Analyst. & 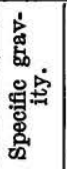 & 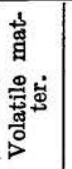 & 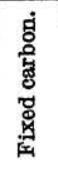 & 岳 & 息 & 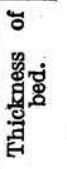 \\
\hline & & $\begin{array}{l}\text { WEST VIRGINIA-Con. } \\
\text { KANAWHA COUNTY. }\end{array}$ & & & & & & & & \\
\hline 183 & 1 & Queen Shoals Coal Co., & $2 \mathrm{c}$ & Hite and Patton. & & 39.3 & 46.0 & 13.9 & 0.8 & $\ldots$ \\
\hline 184 & 3 & $\begin{array}{l}\text { Villa Coal Mining Co., } \\
\text { Villa.b }\end{array}$ & $2 \mathrm{~b}$ & ....do.. & & 45.3 & 43.7 & 10.3 & 1.5 & 53 \\
\hline $\begin{array}{l}184 \mathrm{a} \\
185\end{array}$ & $\begin{array}{l}6 \\
7\end{array}$ & $\begin{array}{l}\text { Cannelton } \\
\text { Lackawan }\end{array}$ & $\begin{array}{l}2 c \\
2 c\end{array}$ & (...do.. & & $\begin{array}{l}43.1 \\
41.3\end{array}$ & $\begin{array}{l}49,5 \\
46.2\end{array}$ & $\begin{array}{r}7.4 \\
12.1\end{array}$ & $\begin{array}{r}1.1 \\
.5\end{array}$ & $\begin{array}{l}0-36 \\
17 \frac{1}{2}\end{array}$ \\
\hline 186 & 11 & $\begin{array}{l}\text { nah mine, } \\
\text { dis } \\
\text { Creek e.... }\end{array}$ & $2 b$ & J. B. Krak.... & & 36.56 & 36.1 & 26.1 & .4 & 36 \\
\hline & & PRESTON COUNTY. & & & & & & & & \\
\hline 187 & 1 & $\begin{array}{l}\text { Left Fork of Sandy Creek, } \\
\text { Marquies. } f \\
\text { LINCOLN COUNTY. }\end{array}$ & $2 c$ & Hite a & & 23.9 & 45.3 & 30 & .6 & 15 \\
\hline $187 \mathrm{a}$ & 1 & John Smith mine, near & 20 & Krak ar & & 39.7 & 54.1 & 5.3 & 1.2 & \\
\hline $187 \mathrm{~b}$ & 2 & $\begin{array}{l}\text { Scites mine, near Jenks } g . \\
\text { GREAT BRITAIN. }\end{array}$ & $2 \mathrm{c}$ & & & 44.2 & 49.9 & 5.0 & .9 & \\
\hline & & English cannel coal $h_{\ldots} \ldots$ & $2 c$ & R. Peter.. & & 42.4 & 54.0 & 2.4 & & \\
\hline & & Lesm & $?$ & & & $j 44.6$ & & & $\ldots$ & \\
\hline & & \%...d & $?$ & & & $j 49.3$ & & & $\cdots$ & \\
\hline & & go cannel, Scot- & $2 \mathrm{~b}$ & Miller.... & 1.25 & 56.7 & 37.2 & 6.0 & 1.14 & $\cdots \cdots \cdot$ \\
\hline & & Way & $?$ & - & & 35 & 2 & 14. & $\ldots$ & $\bullet \cdot$ \\
\hline & & land $i$ & $?$ & vaux.......... & 1.27 & 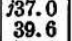 & $\begin{array}{l}60.0 \\
57.6\end{array}$ & $\begin{array}{l}3.0 \\
2.7\end{array}$ & 1.5 & $\ldots$ \\
\hline & & Boghead cannel, Scot- & $2 a$ & - & & 70.1 & 10.3 & 19.6 & & \\
\hline & & Torbanite, Scotlan & $2 a$ & H. How.. & 1.17 & 71.1 & 7.6 & 21.1 & .7 & $\ldots$ \\
\hline
\end{tabular}

a Krebs, C. E., and Teets, D. D., Kanawha County: Wost Virginia Geol. Survey County Repts., p. 439, 1914.

'Idem, p. 453

c MacFarlane, Graham, Notes on American cannel coal: Am. Inst. Min. Eng. Trans., vol. 18, p. 483, 1890.

$d$ Krebs, C. E., and Teets, D. D., op. cit., p. 485.

$e$ Idem, p. 421 .

$f$ Hennen, R. J., and Reger, D. B., Preston County: West Virginia Geol. Survey County Repts., p. 364, 1914 Krrebs, C. E., and Teets, D. D., Boone County: West Virginia Geol. Survey County Repts., p. 404, 1915.

i Owen, D. D., Kentucky Geol. Survey Second Rept., p. 56, 1857.

$j$ Includes moisture.

$l i$ Idem, p. 59. Joint report on the bituminous or oil shales of New Brunswick; also; on the oil-shale industry of Scotland; pt. 2, Geology, p. 33, Canada Dept. Mines, Mines Branch, 1909.

$m$ Gesner, Abraham, Practical treatise on coal, petroleum, and othər distllled oils, p. 48, 1865. 
ANALYSES OF ASH.

In order to round out the groups of analyses the analyses of the ash of a number of cannel coals are given in the following table:

Analyses of ash of cannel coals.

\begin{tabular}{|c|c|c|c|c|c|c|c|c|}
\hline . & Silica. & $\begin{array}{c}\text { Alu- } \\
\text { mina, } \\
\text { oxides } \\
\text { of iron, } \\
\text { and } \\
\text { manga- } \\
\text { nese. }\end{array}$ & Lime. & $\begin{array}{l}\text { Mag- } \\
\text { nesia. }\end{array}$ & $\begin{array}{l}\text { Phos- } \\
\text { phoric } \\
\text { acid. } \\
\text {. }\end{array}$ & $\begin{array}{l}\text { Sul- } \\
\text { phuric } \\
\text { acid. }\end{array}$ & $\begin{array}{l}\text { Potash } \\
\text { and } \\
\text { soda. }\end{array}$ & $\begin{array}{l}\text { Per- } \\
\text { cent- } \\
\text { age of } \\
\text { ash in } \\
\text { sample. }\end{array}$ \\
\hline $\begin{array}{l}\text { Boghead, Carter County, Ky.a } . \ldots . . . . \\
\text { Boghead, Carter County, Ky. (lower }\end{array}$ & 1.88 & 1.68 & 0.27 & 0.63 & & 0.30 & 0.29 & 5.07 \\
\hline 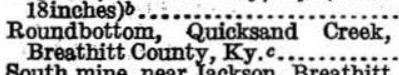 & $\begin{array}{r}2.78 \\
11.58\end{array}$ & $\begin{array}{l}4.2 \\
2.98\end{array}$ & $\begin{array}{r}.55 \\
.21\end{array}$ & $\begin{array}{l}.30 \\
.24\end{array}$ & Tr. & .10 & .28 & $\begin{array}{r}7.87 \\
15.40\end{array}$ \\
\hline 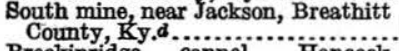 & 1.5 & 1.98 & . 41 & .20 & Tr. & .24 & .48 & 4.90 \\
\hline 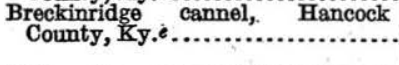 & 3.49 & 7.78 & .53 & .39 & & & & 12.21 \\
\hline
\end{tabular}

a Owen, D. D., Kentucky Geol. Survey Fourth Rept., p. 111, 1861.

$b$ Idem, p. 114 .

c Idem, p. 95.

d Idem, p. 96 .

e Peter, Robert, Second chemical report of the ores, rocks, soils, coals, etc., of Kentucky: Kentucky Geol. Survey Second Rept., p. 211, 1857.

ANALYSES OF OCCLUDED GAS.

No figures were obtained showing the results of dissolving out such parts of cannel coal as would be acted on by pyridine or other solvents. Clarke, ${ }^{1}$ however, quotes from the results of an investigation by Thomas in the extraction of gases in vacuo at $100^{\circ}$ from a number of coals, including some cannels. From his results the following figures have been selected:

Analyses of gases from cannel and other coals.

\begin{tabular}{|c|c|c|c|c|c|c|c|c|}
\hline . & 1 & 2 & 3 & 4 & 5 & 6 & 7 & 8 \\
\hline 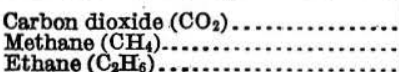 & $\begin{array}{r}6.44 \\
80.69 \\
4.75\end{array}$ & $\begin{array}{r}9.05 \\
77.19 \\
7.80\end{array}$ & $\begin{aligned} 53.94 \\
\cdots \cdots\end{aligned}$ & $\begin{array}{r}84.55 \\
\cdots\end{array}$ & $\begin{array}{r}68.75 \\
2.67\end{array}$ & $\begin{aligned} 36.42 \\
\cdots \cdots\end{aligned}$ & $\begin{array}{l}18.90 \\
67.47\end{array}$ & $\begin{array}{l}14.72 \\
84.18\end{array}$ \\
\hline Propane $\left(\mathrm{C}_{8} \mathrm{H}_{8}\right) \ldots \ldots \ldots$ & & & & .91 & & & & \\
\hline $\begin{array}{l}\text { Oxygen }\left(\mathrm{O}_{2}\right) \\
\text { Nitrogen }\left(\mathrm{N}_{2}\right) \ldots \ldots \ldots \ldots \ldots \ldots \ldots \ldots\end{array}$ & 8.12 & 5.96 & 46.06 & 14.54 & 28.58 & $\begin{array}{r}.80 \\
62.78\end{array}$ & $\begin{array}{r}1.02 \\
12.61\end{array}$ & 1.10 \\
\hline Amount of gas...cubic centimeters.. & $\begin{array}{r}100.00 \\
421.3\end{array}$ & $\begin{array}{r}100.00 \\
350.6\end{array}$ & $\begin{array}{r}100.00 \\
16.8\end{array}$ & $\begin{array}{r}100.00 \\
55.7\end{array}$ & $\begin{array}{r}100.00 \\
55.7\end{array}$ & $\begin{array}{r}100.00 \\
55.9\end{array}$ & $\begin{array}{r}100.00 \\
147.4\end{array}$ & $\begin{array}{r}100.00 \\
600.6\end{array}$ \\
\hline
\end{tabular}
1, 2. Wigan cannel.
3. Scotch cannel, Wilsontown.
4. Scotch cannel, Lesmahago.
5. Cannel shale, Lasswade, near Edinburg.
6. Bituminous coal.
7. Steam coal.
8. Anthracite coal.

The differences here are so striking that they are probably accidental and are due to differences in the time of exposure of the coal in mines and during its removal to the laboratory.

\footnotetext{
${ }^{1}$ Clarke, F. W., The data of geochemistry, 3d ed.: U. S. Geol. Survey Bull, 616, p. 758, 1916.
} 


\section{IGNITING POINT.}

The igniting point of cannel coal is given by Lewes ${ }^{1}$ as $668^{\circ} \mathrm{F}$. or $370^{\circ} \mathrm{C}$., as compared with $842^{\circ} \mathrm{F}$. or $430^{\circ} \mathrm{C}$. for lignite, and $870^{\circ} \mathrm{F}$. or $477^{\circ} \mathrm{C}$. for Welsh steam coal. As is well known, the name cannel comes from candle, the early name of the coal, employed because of the readiness with which a splinter of it ignites and burns "like a candle."

\section{ORIGIN.}

More than 50 years ago Newberry ${ }^{2}$ recognized the fact that cannel coals have the nature of water-laid deposits. According to White and Thiessen ${ }^{3}$ the microscopic study of cannel coals shows that they include fern spores, water weeds, algae, and other material that naturally accumulates in the open water of swamps. The remains of certain water animals-fish, mollusks, amphibians, and crustaceansare in places associated in abundance with cannel coals. Finally, in many places cannel coal grades over into bituminous shale or ordinary shale. In a cut on the Indiana Southern Railroad near Burn City, Daviess County, Ind., a bed of cannel coal, a foot or two thick, grades upward into coal which is similar in appearance, but which, on burning, leaves about half its original bulk as ash, and still higher into material which, though it resembles cannel, is reported by those who have tested it in a stove to leave a volume of ash greater than that of the coal put in. Above that bed the black color gradually turns to gray, and at the top there is only an ordinary gray clay shale. In some areas cannel coal grades into shale horizontally.

The close relation of cannel to shale is also seen in the high ash content of many cannels, due to the washing in of mud during the formation of the coal. Mud washed into an open-water basin tends to accumulate most abundantly at the point of entrance, and cannel forming in such a basin may be quite free of ash in one part and be high in ash in another part.

That the material of cannel coal has been formed by the settling of floating material and not from plants grown in place is further indicated by the fact that cannel coal, unlike bituminous coal, which is generally underlain by a bed of clay containing the roots of plants, in many if not in most places rests on rocks other than clay.

Again, although bituminous coal usually shows distinct banding, supposed to be due to changing surface conditions in the coal marsh, cannel coal is homogeneous, as if the conditions remained constant during the whole period of its deposition.

\footnotetext{
1 Lewes, V. B., The carbonization of coal, etc., p. 22, 1912.

${ }^{2}$ Newberry, J. S., On the mode of formation of cannel coal : Am. Jour. Sci., 2d ser., vol. 23 , p. $212,1857$.

${ }^{3}$ White, David, and Thiessen, Reinhardt, The origin of cosl : Bur. Mines Bull. 38, 1913.
} 
Furthermore, Newberry ${ }^{1}$ has called attention to the fact that in lagoons of open water found near modern peat marshes a fine carbonaceous mud accumulates that, when properly dried, resembles cannel coal in appearance and in many properties.

Many theories have been advanced to account in detail for the formation of cannel coal. According to the theory here stated, it was formed at the bottom of open-water basins or small channels, most of them in coal-forming swamps (as indicated by the almost universal association of cannel with bituminous coal), by a steady accumulation of plant spores, pollen, resins, waxes, and other carbonaceous material. The source of the large percentage of volatile hydrocarbons, especially ethylene gas, which it yields on distillation, remains to be determined. Possibly these hydrocarbons were formed by the decomposition of the inner parts of the spores, having been held in temporary storage within the tough fine-grained spore cases. No study has been made, to the writer's knowledge, of this particular question, though distillation tests have been made on spore dust mixed with fuller's earth. One test reported by Ells, ${ }^{1}$ the conditions of which are not known, yielded 23.8 gallons of crude oil (specific gravity, 0.93) and 3.3 pounds of sulphate of ammonia per ton.

\section{MODE OF OCCURRENCE.}

\section{GENERAL FEATURES.}

- Too much stress can not be put on the fact that cannel coal occurs in very small basins. Thousands of dollars have been wasted in expensive preliminary equipment for mining deposits of cannel coal which proved to contain less than a year's supply. Long railroad spurs, one as much as 12 miles in length, have been built and expensive plants have been erected on the favorable showing presented by a single opening. A cannel-coal basin should therefore be prospected as thoroughly as a gold lode. It should be tested not by drilling every 10 acres but by drilling every acre. Where the coal lies high in the hills it may be sufficiently prospected by drillings or openings 100 yards apart. The fact that thick cannel is found at two points a quarter of a mile apart is no guaranty that it is thick between those points.

1 Newberry, J. S., Ohio Geol. Survey Rept., vol. 2, pt. 1, p. 125, 1874.

2 Ells, R. W., Joint report on the bituminous or oil shales of New Brunswick; also on the oil-shale industry of Scotland; pt. 2, Geology, p. 69, Canada Dept. Mines, Mines Branch, 1909. 
The mode of occurrence of cannel coal may best be understood from the description of two or three typical basins. (See fig. 1.)

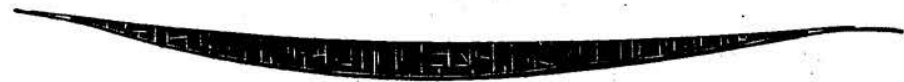

A

B

C

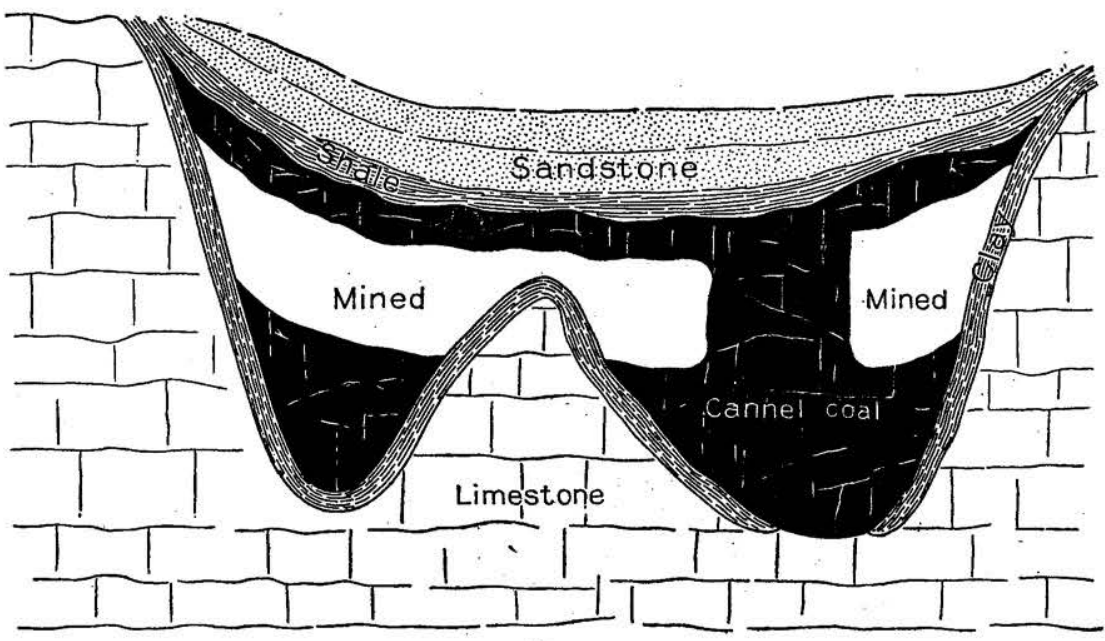

D

Figure 1.-Cross section of cannel-coal basins. A, Cross section of cannel-coal bed at Cannelton, Beaver County, Pa.; B, cross section of cannel-coal basin south of New Bethlehem, in Armstrong County, Pa.; C, cross section of cannel-coal basin on Bear . Run, Bell County, Ky.; D, cross section of cannel-coal basin through an erosion channel in lower Carboniferous limestone in Cooper County, Mo.

\section{DEPOSIT AT CANNELTON, PA.}

The deposit of cannel coal at Cannelton, Beaver County, Pa., occu-: pies a 600-foot channel whose course suggests that it lies in an abandoned oxbow or horseshoe circumscribing a basin 2 miles long by 1 mile wide. Along the center of the channel the cannel coal has a thickness of 15 feet or more, and is underlain by 1 foot of bituminous 
coal. About 150 feet from each side of the axis of the channel the cannel bench has decreased in thickness to 5 feet and the bench of bituminous coal has in places thickened to 2 feet, the bottom of the cannel coal apparently grading into the upper foot of bituminous coal. Within this width of 300 feet the form of the channel is indicated by slight dips toward its axis. Beyond that width the bottom of the channel rises sharply to 20 to 27 feet above the level of the center of the channel and both cannel and bituminous coal thin gradually down to nothing. Over the cannel coal in the center of the channel lies a heavy body of bituminous shale, almost as rich in yield of oil as the cannel coal itself. (See Pl. IV, A.)

The cannel coal here is, as usual, distinctly a block coal, being cut by nearly vertical joints or "slips," most commonly 4 feet apart, along which the coal commonly breaks up into blocks about 4 by 4 feet, though in places the joints are as little as 1 foot apart. As usual in block coal the "face slips" or joints continue unbroken for long distances, and the "butt slips" break and offset somewhat in crossing the face slips. Where examined the face slips ran S. $70^{\circ} \mathrm{E}$., or nearly at right angles to the axis of the basin. In passing from the axis of the basin to the edges the butt slips may be observed to lean toward the axis at the top. At one point where measured this lean amounted to $12^{\circ}$. It was reported by Mr. Mansfield, the owner, that the face slips maintain a constant direction entirely around the oval. As the angle between this constant direction of the slips and the changing direction of the axis of the channel changes in coming about the oval basin, this leaning disappears but reappears on the other side of the oval, where the face slips are again at right angles to the axis of the channel.

DEPOSITS AT BOSTONIA, PA.

The cannel coal in the center of the channel of the coal basin at Bostonia, Armstrong County, Pa. (see fig. 1, B, and fig. 3, p. 59), has a thickness of 9 feet and is underlain by 18 inches of bituminous coal. Coal has been worked from this central axis for a maximum distance of 300 to 400 feet on either side, in which distance the bottom of the basin rises 8 to 10 feet above the bottom of the channel at its axis and the coal decreases in thickness to the minimum that can now be profitably mined. Under more favorable conditions mining could doubtless be pushed a little farther outward from the central axis. This channel, which can be followed for a number of miles (see p. 60) from a point northwesĩ of Bostonia through the surface ridge to the southeast and then eastward, is uniform neither in depth nor width, nor in the character of its coal, which is not everywhere $87775^{\circ}-18-$ Bull. $659-3$ 
cannel. Like most cannel-coal basins it resembles a lagoon rather than a channel cut by running water.

DEPOSIT AT CHENOA, KY.

The cannel-coal channel at Chenoa, Bell County, Ky., is similar to the others just described. The coal in the center of the basin is thick, but within 400 feet on either side it decreases in thickness to the minimum that can be profitably mined. (See fig. 1, C.)

Cannel-coal basins of somewhat different type occur in Missouri, where most of the coal lies in basins eroded in the underlying limestone. One basin (fig. 1, D) about 100 feet wide and of undetermined length, has been followed 500 feet in east and west. The total depth of the coal is more than 70 feet.

Hinds ${ }^{1}$ has described these Missouri pockets as follows:

Pockets are in one sense only outliers but may be distinguished by certain unique features. Briefly stated, they are shale, coal, sandstone, and clay deposits laid down in sink holes or small depressions and surrounded by walls of limestone belonging to Mississippian and older formations. They occur in nearly all parts of the State outside the main Pennsylvanian body and are especially numerous in Lincoln, Callaway, Cooper, Cole, Morgan, Moniteau, and southwestern counties. They are round or elliptical in horizontal cross section, are commonly only a few hundred feet in width, and are in many cases as deep as they are wide. Many contain as much as $\mathbf{3 0}$ to $\mathbf{9 0}$ feet of coal, chiefly of the cannel variety, and have excited much comment. In most cases the component layers are saucer shaped, dipping inward on all sides from the surrounding limestone walls as though the entire mass had slipped down a considerable distance. Fractures and slickensides indicate that part of this slipping occurred after the consolidation of the materials, though many of the coal pockets probably sank during deposition, the action of the humic acids hastening the deepening of the sinks. Sinks that were deepened in this way while sediments were accumulating were probably slightly above ground-water level at that time. Deposition in many sinks probably took place after the drainage outlets at their bases had been choked up as a result of a slight subsidence of the region in which they lie. Some of the shale and sandstone deposits may have been formed after the region was invaded by the continental sea, though this is not necessarily the case. Certainly those containing coal were deposited while the region was free from brackish or salt waters. It is probable that solution was renewed at the bottoms of the sinks whenever ground-water level was lowered as a result of post-Pennsylvanian regional movements and that many of the deposits are still sinking.

\section{USES.}

\section{HEATING.}

High-grade cannel coal is adapted to most of the common uses of other bituminous coals except the making of coke. As it burns freely, it was used in the early days in the manufacture of iron. It

1 Hinds, Henry, and Greene, F. C., The stratigraphy of the Pennsylvanian series in Missouri : Missouri Bur. Geology and Mines, 2d ser., vol. 13, pp. 41-42, 1915. 


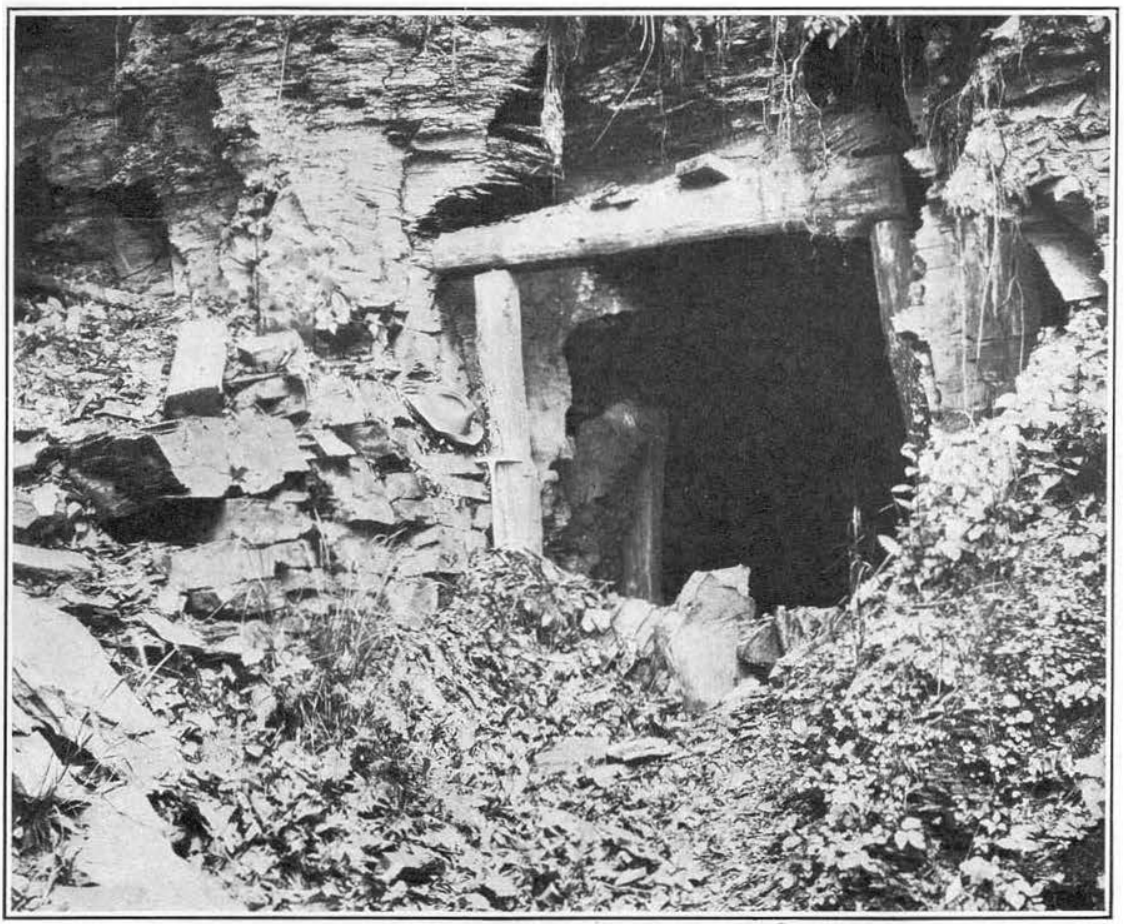

A.

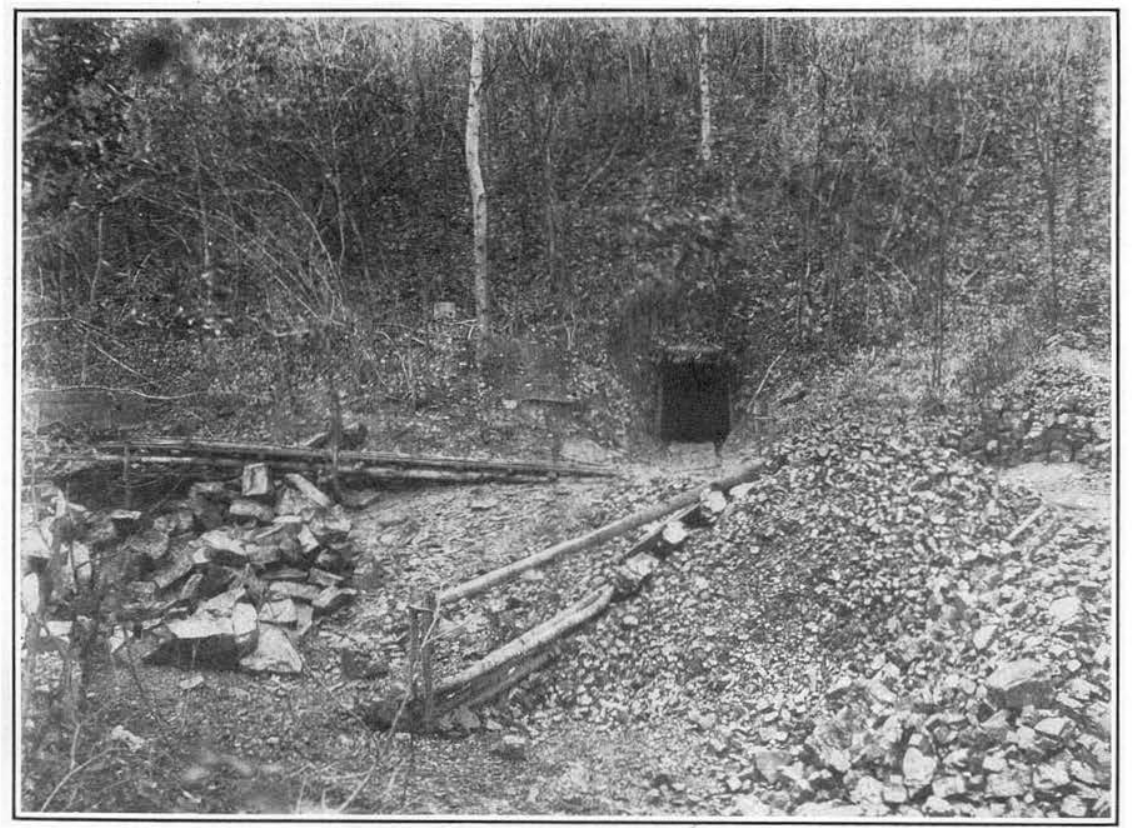

$B$.

CANNEL COAL MINING, PAST AND PRESENT. 

is an ideal grate fuel and has long been used for that purpose, for it mines out in blocks, is clean to handle, and gives a bright, cheerful blaze, resembling that of a wood fire. It differs from wood, however, in containing only a small percentage of moisture, for wood is 50 per cent water, so that it does not require constant replenishing and makes a fire that can be left overnight. Where grates are the principal means of heating houses the special advantages of cannel coal are readily apparent.

Owing to the large percentage of gas it contains cannel coal ignites quickly and is useful where a hot fire is needed in a hurry. It has long been a satisfactory fuel for fire engines and during recent years has found one of its principal markets in city fire departments.

\section{GAS MAKING.}

For many years cannel coal was most largely used for enriching coal gas. Cannel coal does not make a good coke and is not so cheap as other bituminous coals, or its large content of gas of high candlepower would undoubtedly cause it to be used for the manufacture of coal gas to the exclusion of all other coals. The so-called "gas coals" contain 30 to 40 per cent of volatile matter, whereas the better grade of cannel coal contains 50 to 60 per cent, and its gas has double the illuminating power of that in the gas coals. Thus Hocking Valley coal will yield about 8,000 cubic feet of 14-candlepower gas and Westmoreland coal about 10,000 feet of 15 to 16 candlepower gas per ton of coal. By contrast, Flint Ridge, Ohio, cannel will yield 9,000 feet of 23-candlepower gas per ton; Kanawha, W. Va., cannel will yield 10,000 feet of 18 to 19 candlepower; richer cannels will yield from 13,000 to 15,000 cubic feet of 30 to 40 or even 50 candlepower; and according to $\mathrm{McMillin}^{\mathbf{1}}$ some of the special bituminous substances will yield as high as 131 candlepower. According to Stone $^{2}$ the candlepower of the gas from some of the better-known cannel coals is as follows:

\section{Candlepower of gas from cannel coals.}

Breckinridge, $\mathrm{Ky}$

46. 2

Georges Branch, $\mathrm{Ky}$

31.1

Chenoa, $\mathrm{Ky}$ 41. 2

Boghead, $\mathrm{Ky}$ 38.1

Hunnewell, Ky 35.1

Pineville, Ky 44. 55

Falling Rock, W. Va 36.1

Lesmahago, Scotland 34.5

Boghead, Scotland. 38.2

New Battle, Scotland.

35.3

\footnotetext{
${ }^{1}$ McMillin, Emerson, The gas coals of Ohio: Ohio Geol. Survey Rept., vol. 5, Economic geology, pp. 722-749, 1884.

2 Stone, G. W., Kentucky Inspector of Mines Sixteenth Ann. Rept., p. 112, 1900.
} 
As most cities require gas of a higher candlepower than could be obtained from bituminous gas coals alone, it has been necessary to enrich the product by adding to it some gas of higher candlepower, and for many years cannel coal found its principal market for this purpose. Later, cheaper methods, especially the addition or substitution of oil-enriched water gas, were widely adopted, and to-day little or no cannel coal is used for this purpose.

Future demand may again lead to the distillation of cannel coal at high temperatures in order to obtain certain products or by-products. For that reason, as well as for the purpose of showing its behavior when so treated and the compounds it yields, the following data have been assembled:

The percentage of "volatile combustible matter" shown by analysis is not a true index of the amount of fixed gas that may be obtained in practice. Thus, by a series of tests, Wormley ${ }^{1}$ obtained (among other results) from coals yielding $27.7,30.7,37.2,38.0$, and 39.2 per cent of volatile matter on analysis, $3.32,3.51,3.12,3.65$, and 3.35 cubic feet, respectively, of fixed gas per pound of coal. The temperature at which gas is made also affects greatly both the quantity and quality of the gas-the higher the temperature the greater the quantity of gas and the lower the candlepower. Experiment has shown a marked difference in the composition of gas derived from cannel coal and that derived from the bituminous gas coals, as is clearly indicated by the difference in the candlepower of the two gases. This difference consists principally in the smaller percentage of uncombined hydrogen and the larger percentage of olefines, especially ethylene, in cannel gas.

It is due, no doubt, to the abundance of ethylene that cannel coal gas has so high an illuminating value. Though unable to find, at the time of writing, analyses of the volatile matter from cannel coal, the writer recalls analyses in which the percentage of ethylene, for example, was several times as high as in gas from bituminous coal reported in the same table. Ethylene $\left(\mathrm{C}_{2} \mathrm{H}_{4}\right)$ is what is called an unsaturated hydrocarbon-that is, one having the formula $\mathrm{C}_{n} \mathrm{H}_{2 n}$ rather than the formula $\mathrm{C}_{n} \mathrm{H}_{2 \mathrm{n}+2}$. As a result, in burning, it first breaks up into methane, or marsh gas $\left(\mathrm{CH}_{4}\right)$, setting free carbon, which is next heated to incandescence, yielding the light, and then burned to $\mathrm{CO}_{2}$. The significance of the greater percentage of ethylene may be appreciated from the following table given by Lewes: ${ }^{2}$

\footnotetext{
- Wormley, T. G, Report of chemical department: Ohio Geol. Survey Rept. Progress for 1870 , pt. 5, p. $410,1871$.

${ }^{2}$ Lewes, v. B., The carbonization of coal, p. 286, 1912.
} 
Heating value and candlepower of gases derived from coal.

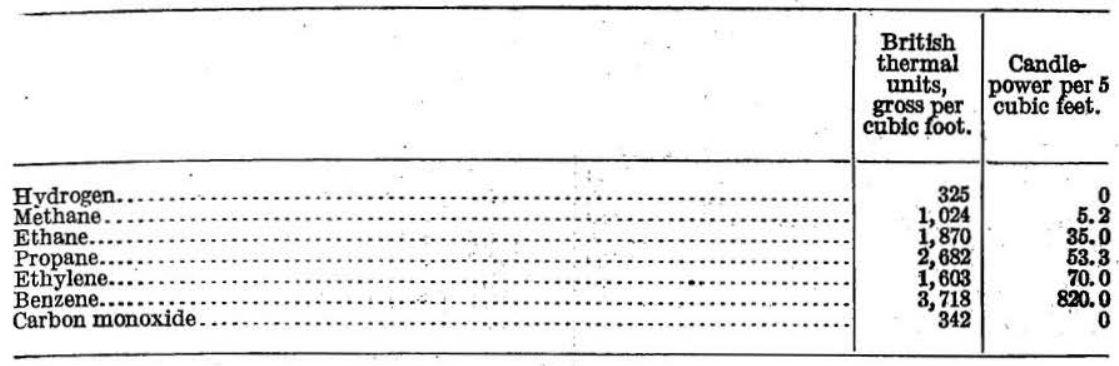

The following table gives the results of tests made to show the quality of gas produced from a number of cannel coals and, for comparison, the results of similar tests of a few bituminous coals. Most of the reports quoted do not indicate whether the long or the short ton is the unit employed, but the long ton (2,240 pounds) is probably the one used in nearly if not quite all of them. Trustworthy comparisons are afforded only by tests reported by the same analyst, for there has been no universal standard for such tests and the results of comparisons between tests made under different conditions are not reliable:

Quantity and quality of gas produced by cannel coals and some gas coals.

\begin{tabular}{|c|c|c|c|}
\hline - & $\begin{array}{c}\text { Gas per long } \\
\text { ton. }\end{array}$ & $\begin{array}{l}\text { Candle- } \\
\text { power. }\end{array}$ & Analyst. \\
\hline 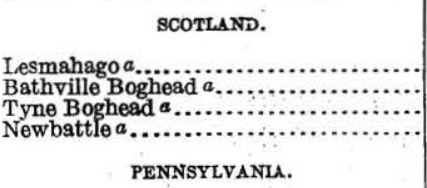 & $\begin{array}{r}\text { Cubic feet. } \\
13,201 \\
14,690 \\
13,155 \\
12,461\end{array}$ & $\begin{array}{l}34.5 \\
42.66 \\
38.2 \\
35.3\end{array}$ & $\begin{array}{l}\text { Hislop, G. R. } \\
\text { Do. } \\
\text { Do. } \\
\text { Do. }\end{array}$ \\
\hline $\begin{array}{l}\text { Pittsbuurgh coal, Rend mines } b \ldots \ldots \ldots \ldots \\
\text { Youghiogheny gas coal } b \ldots \ldots \ldots \ldots \ldots \ldots \\
\text { Washington County, bituminous } c \ldots \ldots \\
\text { Beaver County, cannel } c \ldots \ldots \ldots \ldots \ldots \ldots \ldots \\
\text { Pittsburgh gas coal } c \ldots \ldots \ldots \ldots \ldots \ldots \ldots \ldots\end{array}$ & $\left|\begin{array}{r}11,200 \\
10,300 \\
9,880-10,120 \\
10,160 \\
9,500-10,000\end{array}\right|$ & $\begin{array}{c}15 \\
17 \\
16.1-8.3 \\
22.5 \\
16\end{array}$ & $\begin{array}{l}\text { Columbus Gas Co., Ohio. } \\
\text { Do. } \\
\text { Pittsburgh Testing Laboratory (Ltd.). } \\
\text { Do. } \\
\text { Do. }\end{array}$ \\
\hline 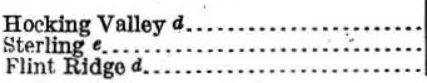 & $\begin{array}{r}8,960 \\
11,782 \\
10,080\end{array}$ & $\begin{array}{l}15 \\
18.8 \\
24\end{array}$ & $\begin{array}{l}\text { Columbus Gas Co., Ohio. } \\
\text { Prof. Chandler. } \\
\text { Columbus Gas Co., Ohio. }\end{array}$ \\
\hline $\begin{array}{l}a \text { Hendrie, Charles, Some Kentucky ce } \\
1894 . \\
b \text { McMillin, Emerson, The gas coals of } \\
\text { 735, 1884. } \\
\text { c'Taff, J. A., Preliminary report on the } \\
\text { Twenty-first Ann. Rept., pt. 2, p. 329, } 1 \\
d \text { McMillin, Emerson, op. cit., p. 733. } \\
\text { e Edwards, W. S., Coals and cokes of }\end{array}$ & $\begin{array}{l}\text { nels: Ker } \\
\text { Ohio: } \mathrm{Ol} \\
\text { amden co } \\
\text { DO. }\end{array}$ & ky Ins & $\begin{array}{l}\text { of Mines Tenth Ann. Rept., p. 154, } \\
\text { y Rept., vol. 5, Economic geology, p. } \\
\text { western Arkansas: U. S. Geol. Survey, }\end{array}$ \\
\hline
\end{tabular}


Quantity and quality of gas produced by cannel coals and some gas coals-Contd.

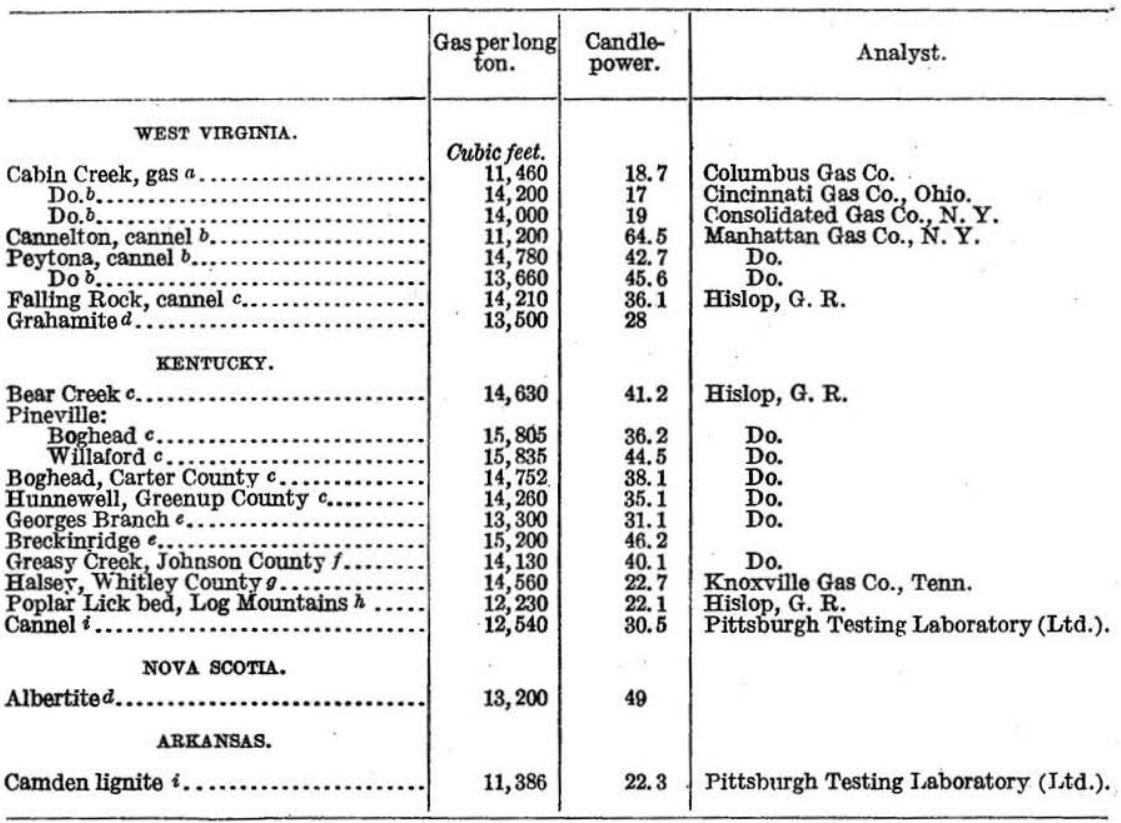

$a$ McMillin, Emerson, op. cit.,p. 736.

$b$ Edwards, W. S., Coals and cokes of West'Virginia, pp. 71-72, 1892.

c Stone, G. W., Kentucky Inspector of Mines Sixteenth Ann. Rept., p. 112, 1900.

d McMillin, Emerson, op. cit., p. 725.

e Hendrie, Charles, op. cit., p. 150.

$f$ Stone, G. W., op. cit., p. 114 .

$g$ Idem, p. 115 .

$h$ Idem p. 117 .

$i$ Taff, J. A., Preliminary report on the Camden coal field of southwestern Arkansas: U. S. Geol. Survey Twenty-first Ann. Rept., pt. 2, p. 329, 1900.

In order that the possible differences in the volumes of gas and the candlepower, due to different temperatures of distillation, may be fully realized in later tables the variation in the volume of gas and tar and in the composition of the gas resulting from the distillation of coal at different temperatures is given below.

Yield of gas and tar per ton of coal carbonized. ${ }^{a}$

\begin{tabular}{|c|c|c|c|c|}
\hline \multicolumn{2}{|c|}{$\begin{array}{l}\text { Temperature of } \\
\text { distillation. }\end{array}$} & \multirow{2}{*}{$\begin{array}{l}\text { Volume } \\
\text { of gas. }\end{array}$} & \multirow{2}{*}{ Tar. } & \multirow{2}{*}{$\begin{array}{l}\text { Specific } \\
\text { gravity } \\
\text { of tar. }\end{array}$} \\
\hline${ }^{\circ} \mathrm{C}$. & ${ }^{\circ} \mathrm{F}$. & & & \\
\hline $\begin{array}{r}900 \\
800 \\
700 \\
600 \\
500 \\
400\end{array}$ & $\begin{array}{r}1,652 \\
1,472 \\
1,292 \\
1,112 \\
932 \\
752\end{array}$ & $\begin{array}{r}\text { Cubic feet. } \\
11,000 \\
10,000 \\
9,000 \\
7,750 \\
6,400 \\
5,000\end{array}$ & $\begin{array}{r}\text { Gallons. } \\
9 \\
12 \\
15 \\
18 \\
21 \\
23\end{array}$ & $\begin{array}{l}1.200 \\
1.170 \\
1.140 \\
1.115 \\
1.087 \\
1.060\end{array}$ \\
\hline
\end{tabular}

$a$ Lewes, V. B., The carbonization of coal, p. 162, 1912.

The figures given are stated to be " average results." 
Effect of temperature of carbonization on the percentages of the chief constitvents of the gas. ${ }^{a}$

\begin{tabular}{|c|c|c|c|c|c|c|}
\hline Temperature $\ldots \ldots \ldots \ldots \ldots \ldots \ldots,\left\{\begin{array}{l}{ }^{\circ} \mathrm{C} . \\
\mathrm{o}\end{array}\right.$ & $\begin{array}{r}400 \\
752 \\
\end{array}$ & $\begin{array}{r}500 \\
932\end{array}$ & $\begin{array}{r}600 \\
1,112\end{array}$ & $\begin{array}{r}700 \\
1,292\end{array}$ & $\begin{array}{r}800 \\
1,472\end{array}$ & $\begin{array}{r}900 \\
1,652\end{array}$ \\
\hline 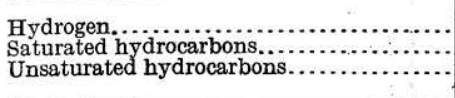 & $\begin{array}{r}21.2 \\
60.1 \\
6.3\end{array}$ & $\begin{array}{r}28,3 \\
56.2 \\
5.8\end{array}$ & $\begin{array}{r}33.8 \\
50.7 \\
5.0\end{array}$ & $\begin{array}{r}41.6 \\
45.0 \\
4.4\end{array}$ & $\begin{array}{r}48.2 \\
\quad 39.1 \\
3.8\end{array}$ & $\begin{array}{r}54.5 \\
34.2 \\
3.5\end{array}$ \\
\hline
\end{tabular}

a Lewes, V. B., The carbonization of coal, p. 163, 1912.

The difference in candlepower resulting from different temperatures of distillation was well shown in experiments by L. T. Wright (quoted by the Encyclopedia Britannica) on four portions of the same coal heated to different temperatures.

Yield and candlepower of gas distilled at different temperatures.

\begin{tabular}{|c|c|c|c|}
\hline & $\begin{array}{l}\text { Gas per } \\
\text { ton. }\end{array}$ & $\begin{array}{l}\text { Tllumi- } \\
\text { nating } \\
\text { power } \\
\text { per } 5 \\
\text { cubic feet } \\
\text { of gas. }\end{array}$ & $\begin{array}{l}\text { Total illu- } \\
\text { minating } \\
\text { power } \\
\text { per ton. }\end{array}$ \\
\hline 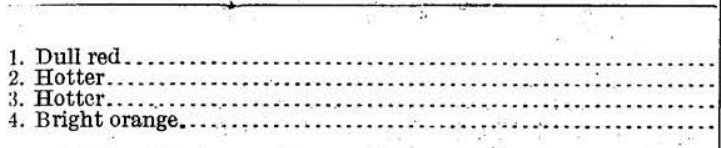 & $\begin{array}{r}\text { Cubic feet. } \\
8,250 \\
9,693 \\
10,821 \\
12,006\end{array}$ & $\begin{array}{r}\text { Candles. } \\
20.5 \\
17.8 \\
16.7 \\
15.6\end{array}$ & $\begin{array}{r}\text { Candles. } \\
33,950 \\
34,510 \\
36,140 \\
37,460\end{array}$ \\
\hline
\end{tabular}

On this subject see further, for American coals, the work of Porter and Ovitz ${ }^{1}$ and Parr and Francis. ${ }^{2}$ The results were summarized by Vignon, ${ }^{3}$ as follows:

1. Imperfect hydrocarbons $\left(\mathrm{C}_{2} \mathrm{H}_{2}, \mathrm{C}_{2} \mathrm{H}_{4}, \mathrm{C}_{6} \mathrm{H}_{6}\right)$ distill chiefly at temperatures below $600^{\circ}$ and disappear at high temperatures.

2. Methane and carbide are very abundant ( 60 to 84 per cent) up to $800^{\circ}$ and then decrease rapidly with temperature.

3. Hydrogen comes off in small quantities (2 to 20 per cent) up to $600^{\circ}$, greatly predominates from 800 to $1,000^{\circ}$, and then sometimes decreases from this temperature up to $1,200^{\circ}$.

4. $\mathrm{CO}$, which ranges from 3 to 11 per cent and averages 6.5 per cent up to $850^{\circ}$, may exceed 30 per cent above $1,000^{\circ}$. Increasing temperature increases the quantity of gas; the gas obtained at $1,000^{\circ}$ has low calorific value and, in general, contains considerable $\mathrm{CO}$.

Detailed tests of some of the best Kentucky cannels have been made by G. R. Hislop, gas engineer of the Paisley Gas Works, Scotland.

${ }^{1}$ Porter, H. C., and Ovitz, F. K., The volatlle matter of coal : Bur. Mines Bull. 1, 1910.

${ }^{2}$ Parr, S. W., and Francis, C. K., The modification of Illinois coal by low-temperature distillation: Illinois Univ. Eng. Exper. Sta. Bull. 24, 1908.

"Vignon, Leo, Fractional distillation of coal : Jour. Gas Lighting, vol. 121, p. 107, 1913. 
Results of tests of Kentucky cannel and bituminous coals.

\begin{tabular}{|c|c|c|c|c|c|c|c|c|}
\hline : & $\begin{array}{c}\text { Carter } \\
\text { County, } \\
\text { Boghead.a }\end{array}$ & $\begin{array}{c}\text { Greenup } \\
\text { County, } \\
\text { Hunnewell.a }\end{array}$ & $\begin{array}{l}\text { Bell County, } \\
\text { Bear Creek. }\end{array}$ & $\underset{\text { Seam. }}{\text { Poplar Lick }}$ & $\begin{array}{l}\text { Mason } \\
\text { (Mingo) } \\
\text { seam.b }\end{array}$ & $\begin{array}{l}\text { Lower } \\
\text { lignite } \\
\text { seam.b }\end{array}$ & $\begin{array}{l}\text { Johnson } \\
\text { County, } \\
\text { Greasy } \\
\text { Creek.c }\end{array}$ & $\begin{array}{l}\text { Breathitt } \\
\text { County, } \\
\text { Georges } \\
\text { Creek.c }\end{array}$ \\
\hline Specific gravity. & 1.175 & 1.215 & & & & & 1.191 & 1.350 \\
\hline hemica & & & & & & & & \\
\hline $\begin{array}{l}\text { Moisture expelled } \\
\text { Volatile matter.. }\end{array}$ & 1.21 & 2.75 & & & & & & \\
\hline 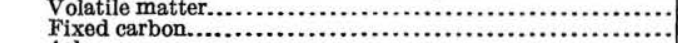 & $\begin{array}{l}54.92 \\
35.17\end{array}$ & $\begin{array}{l}47.23 \\
43.58\end{array}$ & …... & $\cdots \cdot$ & $\cdots$. & ' & $\begin{array}{r}0.75 \\
52.67\end{array}$ & 50.00 \\
\hline Ash............... & 8.08 & 5.55 & & 1 & & $\cdots$ & 46.58 & 44.00 \\
\hline Gaseous products: & & & & & & & & \\
\hline 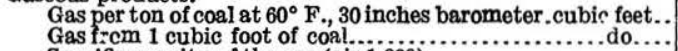 & $\begin{array}{l}14,752 \\
541.37\end{array}$ & $\begin{array}{l}14,260 \\
483.44\end{array}$ & $\begin{array}{r}14,630.00 \\
470.25\end{array}$ & $\begin{array}{r}12,230.00 \\
422.09\end{array}$ & $\begin{array}{r}11.895 .00 \\
406.55\end{array}$ & $\begin{array}{r}12,520.00 \\
432.11\end{array}$ & $\begin{array}{c}14,130.00 \\
. \ldots \ldots \ldots \ldots\end{array}$ & $\begin{aligned} 13,303 \\
\cdots \cdots . . .\end{aligned}$ \\
\hline 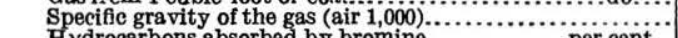 & 700 & 600.44 & 745.00 & 510.00 & 514.00 & 512.00 & $\mid \cdots \cdots \cdots \cdots \cdots \cdots \cdots \cdots \cdots$ & $\ddot{*}$ \\
\hline $\begin{array}{l}\text { Hydrocarbons absorbed by bromine } \\
\text { Durability of } 1 \text { cubic foot by } 5 \text {-inch jet fiame........ minutes.. }\end{array}$ & $\begin{array}{l}15.33 \\
72^{\prime} 4^{\prime \prime}\end{array}$ & $\begin{aligned} 14.25 \\
66^{\prime} 48^{\prime \prime}\end{aligned}$ & $\begin{aligned} 18.30 \\
78^{\prime} 45^{\prime \prime}\end{aligned}$ & $47^{\prime} \cdot 16^{\prime \prime}$ & $46^{\prime} \cdot 51^{\prime \prime}$ & $48^{\prime} \cdot 10^{\prime \prime}$ & & \\
\hline $\begin{array}{l}\text { Value of } 1 \text { cubic foot of gas (sperms) } \ldots \ldots \ldots \ldots \ldots \ldots \text { gr } \\
\text { Value of gas from } 1 \text { ton of col (sperms). }\end{array}$ & 915.60 & 843.12 & 989.76 & 535.84 & 524.84 & 543.60 & $1.945,09$ & \\
\hline $\begin{array}{l}\text { Value or gas from } 1 \text { ton of } \\
\text { Illuminating power of ga }\end{array}$ & 38.15 & 35.13 & 41.24 & 22.16 & 21.86 & 22.65 & $\begin{array}{r}1,80.09 \\
40.15\end{array}$ & 31.15 \\
\hline $\begin{array}{l}\left.\text { Sulphureted hydrogen ( } \mathrm{H}_{2} \mathrm{~S}\right) \text { in foul } \\
\text { Carbon dioxide }\left(\mathrm{CO}_{2}\right) \text { in foul gas... }\end{array}$ & $\begin{array}{l}1.25 \\
2.50\end{array}$ & $\begin{array}{l}1.75 \\
2.50\end{array}$ & $\begin{array}{l}1.20 \\
1.80\end{array}$ & $\begin{array}{l}0.75 \\
2.00\end{array}$ & $\begin{array}{l}1.00 \\
1.75\end{array}$ & $\begin{array}{l}0.80 \\
2.20\end{array}$ & $\begin{array}{r}1.50 \\
2.00\end{array}$ & $\begin{array}{r}1.0 \\
2.8\end{array}$ \\
\hline $\begin{array}{l}\text { Carbon monoxide (CO) in foul gas............ } \\
\text { Sulphur eliminated with volatile products. }\end{array}$ & $\begin{array}{l}7.00 \\
9.85\end{array}$ & $\begin{array}{r}5.50 \\
12.09\end{array}$ & $\begin{array}{l}7.75 \\
9.18\end{array}$ & 7.25 & 6.00 & $\begin{array}{l}7.00 \\
6.04\end{array}$ & 7.75 & ........ \\
\hline Liquid products: & & & & & & & & \\
\hline 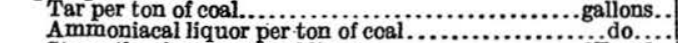 & $\begin{array}{r}20.34 \\
4.43\end{array}$ & $\begin{array}{l}20.12 \\
11.31\end{array}$ & $\begin{array}{r}26.68 \\
6.30\end{array}$ & $\begin{array}{l}15.22 \\
17.30\end{array}$ & $\begin{array}{l}15.81 \\
18.62\end{array}$ & $\begin{array}{l}16.30 \\
16.37\end{array}$ & & \\
\hline Strength of ammoniacal liquor....................... & 4.0 & 3.00 & 5.00 & 2.75 & 2.75 & 2.75 & & $\cdots$. \\
\hline $\begin{array}{l}\text { Hygrometric water per ton of coal. } \ldots \ldots \ldots \ldots \text { gallons.. } \\
\text { Aqueous absorbent capacity of coal (determined by com- }\end{array}$ & 27 & 6.16 & 3.40 & 9.99 & 9.74 & 12.32 & & \\
\hline $\begin{array}{l}\text { plete saturation) ..................................... per cent. } \\
\text { lia products: }\end{array}$ & 1.35 & 2.80 & 1.75 & 5.50 & 5.25 & 5.36 & & \\
\hline 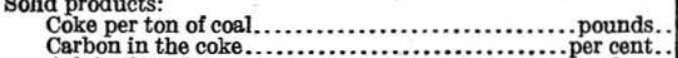 & $\begin{array}{r}972.83 \\
81.40\end{array}$ & $\begin{array}{r}1,108.35 \\
88.80\end{array}$ & $\begin{array}{r}994.78 \\
92.30\end{array}$ & $\begin{array}{r}1,384.32 \\
97.70\end{array}$ & $\begin{array}{r}1,395.52 \\
98.80\end{array}$ & $\begin{array}{r}1,357.44 \\
96.50\end{array}$ & $\begin{array}{r}1,043.39 \\
88.46\end{array}$ & 937 \\
\hline 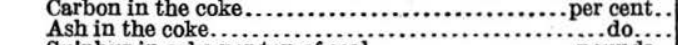 & 18.60 & $\begin{array}{l}88.80 \\
11.20\end{array}$ & 9.70 & 2.30 & 1.20 & $\begin{array}{r}3.50 \\
\end{array}$ & 11.54 & iii. \\
\hline Sulphur in coke per ton of coal. & & 7.84 & 3.5 & t & to & & & \\
\hline 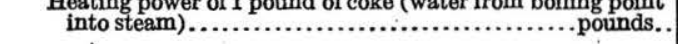 & 11.18 & 12.20 & 12.68 & 13.42 & 13.57 & 13.25 & & \\
\hline
\end{tabular}

a Phalen, W.C., Economic geology of the Kenova quadrangle: U. S. Geol. Survey Bull. 349, p. 90, 1908.

$b$ Ashley, G. H., and Glenn, L. C., Geology and mineral resources of part of Cumberland Gap coal field, Ky.: U. S. Geol. Survey Prof. Paper 49, p. $218,1906$.
$c$ Hendrie, Charles, Some Kentucky cannels: Kentucky Insp. Mines Tenth Ann. Rept., p. 136, 1894. 
The three bituminous coals in the above table are of gas-coal quality, having a percentage of volatile hydrocarbons above 35. Comparison between them and the cannel coals shows that the cannels yield a higher specific gravity, higher candlepower, and higher value per cubic foot in sperms. It also shows that the cannels yield more tar, though this is in a measure offset by their smaller yield of ammoniacal liquor. The bituminous coals, on the other hand, yield more and better coke.

Writing in 1893 , Hendrie ${ }^{1}$ describes some of the effects of substituting water gas for the gas formerly enriched with cannel coal:

The Consolidated Gas Co. of New York in former years used to use from 25,000 to 30,000 tons of cannel per annum for enriching purposes. They now use only a few thousand tons. This applies to all the large gas works in this country. On the other hand, the handling of large quantities of naphtha oil is attended with great risk and danger, especially in large cities, and a first-class cannel will always find a ready market at a certain price, and this to a great extent is governed by the question of transportation. There is a good market in South America, England, and portions of the Continent. The exhaustion of the English cannels is rapidly taking place, and Kentucky alone can take their place in any quantity. Toward the end of 1892 the city of London ceased to use cannel gas, an event marking an important epoch in the cannel trade. This was caused by the fact that about the only available cannel in quantity coming into this market-the Scotch Lesmahagow-cost 58 shillings per ton, delivered in the Thames. Sufficient quantity could not even be obtained at this price, and as ordinary coal will not yield $\mathbf{1 6}$ candlepower gas crude oil from Russia is employed to maintain the statutory power. By this means the gas companies in that city were able to furnish 16 candlepower gas at 3 shillings 1 pence per 1,000 cubic feet, as against 4 shillings 9 pence for cannel gas, a difference which the public were quick to appreciate and accede to. The large amount of gas now used for cooking purposes has also tended to lessen the demand for a gas of high illuminating power.

\section{COKE MAKING.}

It is well known that cannel coal will not make good coke. It belongs to the group of free-burning coals which do not intumesce or run together into a cake, and the coke made from it is, as a rule, pulverulent and soft, that made from some beds crumbling at once to powder. It would seem to be feasible to use this coke in the production of water gas or producer gas or for burning under furnaces as dust, but not in metallurgy nor for stove use.

\section{OII MAKING.}

The use of cannel coal of most interest, both in the past and in the future, however, is in the production of oil and other chemical by-products. It was this use that led to its widespread mining from 1855 to 1859 , when the discovery of petroleum opened the way to its

${ }^{1}$ Hendrie, Charles, Some Kentucky cannels : Kentucky Inspector of Mines Tenth Ann. Rept., p. 149, 1894. 
displacement, and it is this use that is apparently again calling attention to it, the oil now being demanded for conversion into the lighter hydrocarbons (especially gasoline) for use in portable motors and the by-product chemicals for the enlarging chemical industry of the country.

The use of coal for the production of oil is not recent, it having been employed for the purpose as early as 1760. In Lewis's Materia Medica, published in that year, mention is made of oils distilled from black bituminous shales for medical purposes. Even earlier than that, in 1694, patents were issued, according to Gesner, ${ }^{1}$ to Eele, Hancock, and Portlock for making "pitch, tar, and oyle out of a kind of stone." In 1781 the Earl of Dundonald distilled oil from coal, and others distilled oils and tars from bituminous schists, so that at an early date these oils, somewhat purified, were used for burning in lamps and for lubricating machinery.

Abraham Gesner claims to have been the first to manufacture oil from coal in the United States, and in 1846 exhibited the use of his oil in lamps. His patents, known as the "kerosene patents," granted nine years later, were sold to the North American Kerosene Gaslight Co., which proceeded to make and sell "kerosene oil," as it was called. This early oil was not so highly refined as kerosene is to-day. and a disagreeable odor in burning kept down its sale. It came into common use about 1854. In the autumn of 1855 work was begun at Breckinridge, $\mathrm{Ky}$., on an oil distillery, and by April, 1856, 12 retorts were in operation there, producing 600 to 700 gallons daily. In June, 1856, the Breckinridge Coal \& Oil Co. consolidated with the Breckinridge Cannel Coal Co., and 18 more retorts were added.

The rapid extension in the refining of oil from cannel coal and other bituminous substances has been described by Baskerville, ${ }^{2}$ as follows:

In 1853 the United States Chemical Manufacturing Co. began working coal tar for the manufacture of lubricating oil at Waltham, Mass., and in 1857 the Downer Kerosene Oil Co. first made mineral oils from Albert coal mined in New Brunswick. The large works of Downer, in Boston, were erected at a cost of half a million dollars; and at Portland, Me., Downer erected a smaller works for distilling imported coal. About this time the New Bedford Co., of New Bedford, Mass., commenced the distillation of Boghead coal, imported from Scotland, but later substituted domestic Breckinridge coal and West Virginia coal for the imported material.

In 1859 six plants were erected by various companies near Pittsburgh, Pa., and one of these (the Lucesco Co.) had a distilling capacity of 6,000 gallons of crude oil per day. This company had $\$ 120,000$ invested in its works, and in 1860 ten large revolving retorts were in operation. Sixteen 2,000-gallon stills

${ }^{1}$ Gesner, Abraham, Practical treatise on coal, petroleum, and other distilled oils, 2d ed., p. 8, New York, Bailliere Bros., 1865.

${ }^{2}$ Baskerville, Charles, Economic possibilities of American oil shales: Eng. and Min. Jour., vol. 88, p. 151, 1909. 
were used in the refinery. Many of the companies in operation worked under licenses from the Young Co., of Scotland. In 1860 there were fifty-five coal-oil companies in existence in the United States. These were as follows:

Adair \& Veeder, Pittsburgh, Pa. Aladdin Co., Kiskiminitas, Pa. Anderson Co., Darlington, Pa. Atlantic Co., New York, N. Y. Beloni \& Co., New York, N. Y. Boston \& Portland Co., Boston, Mass. Breckinridge Co., Cloverport, $\mathbf{K y}$. Brooks Co., Zanesville, Ohio. Carbon Co., New York, N. Y. Cornell \& Co., Canfield, Ohio. Covington Co., Covington, Ky. Cox Co., Zanesville, Ohio. Dean Có., Cleveland, Ohio. Downer Co., Boston, Mass. East Cambridge Co., East Cambridge, Mass.

Empire State Co., New York, N. Y. Enon Valley Co., Enon Valley, Pa. Eureka Co., New York, N. Y. Excelsior Co., New York, N. Y. Falling Rock Co., Kanawha, Va. [now W. Va.].

Forest Hill Co., Kanawha, Va. [now W. Va.].

Franklin Co., New York, N. Y. Glendon Co., Boston, Màss. Grasseli Co., Cincinnati, Ohio.

(ireat Kanawha Co., Kanawha, Va. [now W. Va.].

Great Western Co., Newark, Ohio. Greers Co., Kanawha, Va. [now W. Va.].
Hartford Co., Hartford, Conn. Himebaugh \& Co., Coshocton, Ohio. Kerosene Co., New York, N. Y. Knickerbocker Co., New York, N. Y. Long Island Co., New York, N. Y. Lucesco Co., Kiskiminitas, $\mathrm{Pa}$. New Bedford Co., New Bedford, Mass. New York \& Wheeling Co., Wheeling, W. Va.

New York Coal Oil Co., New Galilee, Pa. North American Co.,Kiskiminitas, $\mathrm{Pa}$. Orion Co., New York, N. Y. Page \& Co., Boston, Mass. Palestine Co., Palestine, Pa. Peasley Co., Boston, Mass. Phoenix Co., Cincinnati, Ohio. Pictou Co., New York, N. Y. Pinkham Co., Boston, Mass. Preston Co., Virginia [now w. Va.]. Ritchie Co., Ritchie County, Va. Robinson Co., Perry County, Ohio. Sherwood Co., Canfield, Ohio. Stamford Co., Stamford; Conn. Staunton Co., Kanawha, Va. [now W. Va.].

Union Co., Maysville, Ky.

Western Co., Cincinnati, Ohio.

White-Day Co., Monongahela County, Va. [now W. Va.].

Zephyr Co., New York, N. Y.

Many of the above-mentioned companies were of small capacity, and most of them were not more than fairly started when the discovery of petroleum paralyzed the industry. The owners were threatened with considerable loss, from which they were rescued, however, by converting their oil works into petroleum refineries, this being accomplished with little outlay of time or money.

Modern methods of distilling cannel coal would doubtless follow in the main the methods now used in Scotland and Germany in the distillation of oil shale, described by Baskerville ${ }^{1}$ and by Ells. ${ }^{2}$ Baskerville has also described the methods in use in the United States when cannel coals were formerly distilled for oil.

${ }^{1}$ Baskerville, Charles, Economic possibilities of American oil shales: Eng. and Min. Jour., vol. 88, pp. 152-153, 1909.

2 Ells, R. W., Joint report on the bituminous or oil-shales of New Brunswick; also, on the oll-shale industry of Scotland; part 1, Economics, pp. 13-14, Canada Dept. Mines, Mines Branch, 1910. 
About 1860 two types of retorts were in use in the United States and Canada, viz, the horizontal D-shaped retorts and revolving retorts. The former were made of both iron and clay and were from 30 to 45 inches in width and 8 to 10 feet in length. A retort 10 feet in length was capable of distilling three charges of cannel coal of 450 pounds each in 24 hours at a heat not exceeding $415^{\circ}$. Two or three of these retorts were heated over one furnace, and often as many as forty discharged into a common main. The discharge pipes leading from the retorts to the main were about 8 inches in diameter, and they were inserted into the end of the retort opposite the head and the furnace. The main was generally 3 feet in diameter.

The revolving retorts were iron or clay cylinders, 6 feet in diameter and 8 feet in length, sustained upon an axle at each end, the vapors passing through the axle opposite the furnace. The cylinders were kept in motion by machinery and made two or three revolutions per minute. One of these retorts ran six charges of one ton each in 24 hours. In using this retort a saving of fuel was found, but they were more expensive and more liable to get out of order. Consequently the horizontal D-shaped retort was favored.

The largest stills for refining were about 8 feet 6 inches in diameter and 4 feet 6 inches in height. The condensing worms were about 100 feet in length, with a diameter of 6 inches where they left the necks and 4 inches throughout the middle parts, tapering down to 2 inches at the tail pipes. The oil was refined as follows: After the water had settled from the oil and had been drawn off, the crude oil was generally distilled in a common iron still. When the oil had been " run off" to four-fifths of the whole quantity, steam was let into the still, and frequently superheated steam was used.

The first distillate was separated into two parts, the first being that which distilled over from the commencement until the specific gravity reached 0.843 . This oil, which constituted the lamp oil, was placed in "an iron cistern and agitated from one to two hours with from 4 to 10 per cent of sulphuric acid, and then allowed to settle for eight hours. The oil was then washed with 10 to 20 per cent water and afterward with 5 to 10 per cent soda solution (specific gravity 1:40). After settling for six hours the oil was again washed with water and run into a still for final rectification. When the specific gravity reached 0.819 the distillation was stopped and the residue was transferred to the heavy oil.

The heavy oil was that portion of the crude oil which formed the second part of the first distillate. It was generally distilled off in steam to the end of the distillation. The heavy oils were purified in much the same manner as the lighter oils, excepting more acid and stronger alkali solutions were employed. The paraffin wax was crystallized from the heavy oil by exposing it in tanks in a cool place. The oil was pressed out from the wax, which was then purified by acid and alkalies, pressed, and finally cast in molds. Certain alterations of these general methods of retorting and refining were made in New Brunswick in 1864-65. Whether they were improvements or not, we are not able to ascertain.

\section{DISTILLATION FOR BY-PRODUCTS.}

The renewed interest in cannel coal is largely based on its supposed value as a source of what were formerly considered by-products in the manufacture of artificial gas, but which at present have be- 
come of primary importance. The figures already given indicate clearly that certain lean or semicannel coals, though suitable for certain uses (as in household grates), have no advantage over bituminous coals in the production of gas or oil. The figures also show, however, that the higher-grade cannel coals yield a variable but always larger percentage of the coal gas, coal oil, and ammoniacal liquor, and it is hoped that some method may be found for obtaining benzol and its derivatives from these by hydrogenation.

Both the quantity and the quality of the products obtained by the destructive distillation of coal depend on the temperature and pressure and some other factors of the distillation. (See pp. 39 and 48.) If the temperature of distillation is $1,000^{\circ}$ to $1,200^{\circ} \mathrm{F}$. or more, a large volume of gas will be driven off and there will remain a small quantity of tar, from which the coal-tar products are derived, and a large quantity of coke, usually equivalent to more than one-half the weight of the coal. If, however, the temperature of distillation be kept below $800^{\circ}$. F. the quantity of gas will be much reduced, the quantity of coke possibly a little increased, and a considerable volume of oil given off in place of the coal tar.

Munroe ${ }^{1}$ has summarized by classes a few of nearly a thousand derivatives of the ammoniacal liquor and tar obtained in making coal gas. From the ammoniacal liquor are obtained ammonium carbonate, sulphide, polysulphide, chloride, cyanide, sulphocyanide, and other combinations, depending on the process employed. The coal tar yields the benzene series, including benzene, naphthalene, fluorene, phenanthrene, and anthracene; nitrogen-containing compounds, as aniline, the pyridines, the picrolines, quinolines, isoquinolines; sulphur compounds, as thiophene; and hydroxy compounds, as phenols and cresoles. From these substances are derived cleansing compounds, paints, and paint removers; dyestuffs, as the aniline dyes, synthetic alizarine, and indigo; antiseptics and germicides, as carbolic acid and the naphtholes; explosives, as picric acid and trotile; flavoring materials, as methyl, salycilate, and vanilline; perfumes, as geran oil and artificial musk; febrifuges, as antipyrene and acetanilid; sweetening principles, as saccharine; photographic developers, as hydroquinone; etc.

A number of cannel-coal samples obtained by the writer in Pennsylvania were subjected to dry distillation in 1914-15 under the direction of D. T. Day. A preliminary series of tests were made by J. A. Dorsey at the Geological Survey, and a second series by C. R. Bopp at the Bureau of Mines.

\footnotetext{
${ }^{1}$ Munroe, C. E., By-products in gas manufacture : Franklin Inst. Jour., vol. 174, p. 17,
} 1912. 
Dry distillation tests of Pennsylvania cannel coals $(1.914-15) .^{a}$

[By J. A. Dorsey and C. R. Bopp.]

\begin{tabular}{|c|c|c|c|c|c|c|c|c|}
\hline \multirow{3}{*}{ Source. } & \multicolumn{3}{|c|}{ First test. } & \multicolumn{5}{|c|}{ Second test. } \\
\hline & \multirow{2}{*}{$\begin{array}{l}\text { Coal. } \\
\text { used. }\end{array}$} & \multicolumn{2}{|c|}{ Oil. } & \multirow[b]{2}{*}{$\begin{array}{l}\text { Coal } \\
\text { used. }\end{array}$} & \multicolumn{4}{|c|}{ Yield per short ton. } \\
\hline & & $\begin{array}{l}\text { From } \\
\text { sam- } \\
\text { ple. }\end{array}$ & $\begin{array}{l}\text { Per } \\
\text { short } \\
\text { ton. }\end{array}$ & & Oil. & Water. & Gas. & Am- \\
\hline $\begin{array}{l}\text { Center County: } \\
\text { Lula mine } \\
\text { Clearfield County: }\end{array}$ & $\begin{array}{r}\text { Grains. } \\
100\end{array}$ & C. $c_{5}$ & $\begin{array}{c}\text { Gals. } \\
12.0\end{array}$ & $\mathrm{Oz}_{6}$ & $\underset{10.7}{G a l s}$ & Gals. & Cu.ft. & $\begin{array}{l}\text { Pounds. } \\
1.8\end{array}$ \\
\hline $\begin{array}{l}\text { Clearfield County: } \\
\text { Jury mine.......................... }\end{array}$ & & & & & & & & \\
\hline 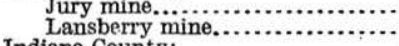 & $\begin{array}{l}100 \\
100\end{array}$ & $\begin{array}{l}5 \\
5\end{array}$ & $\begin{array}{l}12 . \\
12\end{array}$ & $\begin{array}{l}6 \\
6\end{array}$ & $\begin{array}{l}14 \\
10.5\end{array}$ & $\begin{array}{l}7 \\
7\end{array}$ & $\begin{array}{l}4,467 \\
4,467\end{array}$ & $\begin{array}{l}2.39 \\
5.14\end{array}$ \\
\hline $\begin{array}{l}\text { Indiana County: } \\
\text { Altoona mine. }\end{array}$ & 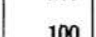 & & & 6 & 20 & 77 & & \\
\hline Armstrong County: & 100 & 10 & 24 & 0 & 20.3 & 7.7 & 4,790 & 5.57, \\
\hline $\begin{array}{l}\text { Bostonia mine } \ldots \ldots \ldots \ldots \ldots \ldots \\
\text { Pine Run No. } 1 \ldots \ldots \ldots \ldots \ldots\end{array}$ & 100 & 17 & 40.8 & 6 & 33.6 & 78 & 5,029 & 5.37 \\
\hline $\begin{array}{l}\text { Pine Run No. } \\
\text { Pine Run No. } 3 \ldots \ldots \ldots \ldots \ldots \ldots\end{array}$ & 100 & $\begin{array}{r}14 \\
8\end{array}$ & $\begin{array}{l}35.0 \\
19.2\end{array}$ & $\begin{array}{l}0 \\
6\end{array}$ & $\begin{array}{l}20.2 \\
31.5\end{array}$ & $\begin{array}{l}9.8 \\
8.4\end{array}$ & $\begin{array}{l}5,029 \\
4,311\end{array}$ & $\begin{array}{l}5.0 \\
3.6\end{array}$ \\
\hline Beaver County: & & & & & & & & \\
\hline 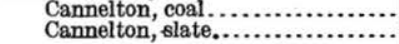 & 100 & 21 . & 50.4 & $\cdots 6$ & 37.3 & 10.5 & 5,268 & 2.24 \\
\hline & & & & & & & 2,900 & \\
\hline
\end{tabular}

a Ashley, G. H., Oil resources of black shales of the eastern United States: U. S. Geol. Survey Bull. 641, p. $319,1917$.

In the following tests a thousand grains of coal were submitted to distillation by Peter, the heat being gradually raised to a dull red. The oil, ammonia, and coke were collected in a train of three tubulated receivers and the gas in a bell glass.

Tests of 1,000 grains of Kentucky cannels (1856-1859).

[By R. Peter.]

\begin{tabular}{|c|c|c|c|c|c|}
\hline Source. & \multicolumn{2}{|c|}{ Gas. } & Oil. & $\begin{array}{l}\text { Ammo- } \\
\text { niacsl }\end{array}$ & Coke. \\
\hline $\begin{array}{l}\text { Breathitt County: } \\
\quad \text { No. } 6, \text { Quicksand Creek } a \ldots \ldots \ldots \ldots \ldots \ldots \ldots \\
\text { Jackson } a \ldots \ldots \ldots \ldots \ldots \ldots \ldots \ldots \ldots\end{array}$ & $\begin{array}{r}\text { Grains. } \\
120 \\
134\end{array}$ & $\begin{array}{r}\text { Cu.in. } \\
860 \\
675\end{array}$ & $\begin{array}{l}\text { Grains. } \\
273 \\
364\end{array}$ & $\begin{array}{r}\text { Gals. } \\
30 \\
36\end{array}$ & $\begin{array}{c}\text { Grains. } \\
576.7 \\
466\end{array}$ \\
\hline 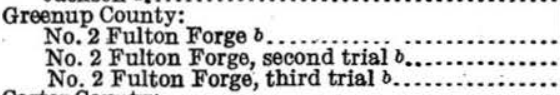 & $\begin{array}{l}170 \\
153 \\
145\end{array}$ & $\mid \begin{array}{ll} \\
\cdots \cdots \cdots \\
\cdots \cdots\end{array}$ & $\begin{array}{l}209 \\
200 \\
189\end{array}$ & $\begin{array}{r}78 \\
99 \\
111\end{array}$ & $\begin{array}{r}543 \\
548 \\
555\end{array}$ \\
\hline 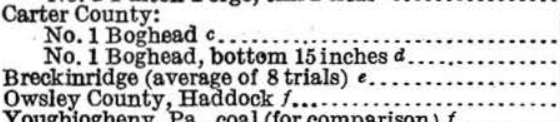 & \begin{tabular}{l}
140 \\
182 \\
162 \\
\hdashline 13
\end{tabular} & $\begin{array}{l}670 \\
675 \\
445 \\
370\end{array}$ & $\begin{array}{l}436 \\
411 \\
318 \\
248.5\end{array}$ & $\begin{array}{l}40 \\
40 \\
52 \\
55\end{array}$ & $\begin{array}{l}384 \\
367 \\
455 \\
589\end{array}$ \\
\hline Youghiogheny, Pa., coal (for comparison) $f . . \ldots \ldots \ldots$ & 102 & & 136 & 52 & 710 \\
\hline
\end{tabular}

a Owen, D. D., Kentucky Geol. Survey, Fourth Rept., p. 95, 1861.

$b$ Idem, p. 171 .

c Idem, p. 111 .

d Idem, p. 114.

e Idem, p. 216.

$f$ Peter, Robert, Second chemical report of the ores, rocks, soils, coals, etc., of Kentucky: Kentucky Geol. Survey Second Rept., p. 217, 1857.

Gesner ${ }^{1}$ gives a table showing the production of oil, volatile matter, and coke from a number of cannel and bituminous coals and

1 Gesner, Abraham, Practical treatise on coal, petroleum, and other distilled oils, 2d ed., p. 56, 1865. 
other bituminous substances, from which the following have been selected:

Yield of oil, coke, and volatile matter from cannel and other coals.

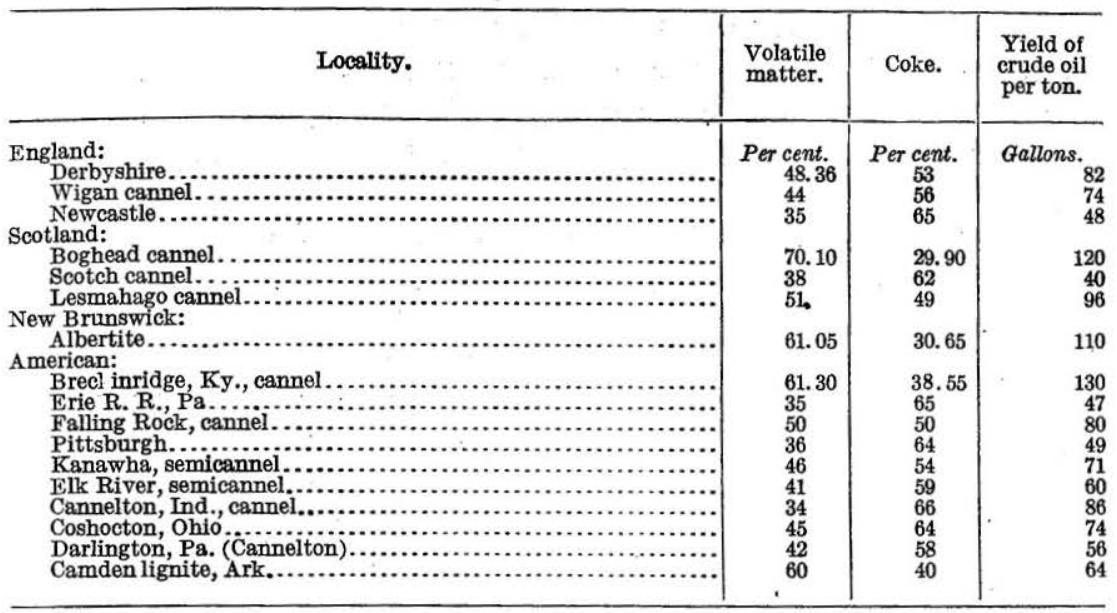

$\mathrm{He}$ also gives the following figures showing the yield of illuminating oil and paraffin oil from Breckinridge and Boghead coal:

Refined products of oils from cannel coals. ${ }^{a}$

\begin{tabular}{|c|c|c|}
\hline$\cdot$ & $\begin{array}{l}\text { Breckin- } \\
\text { ridge. }\end{array}$ & Boghead. \\
\hline \multirow{4}{*}{ 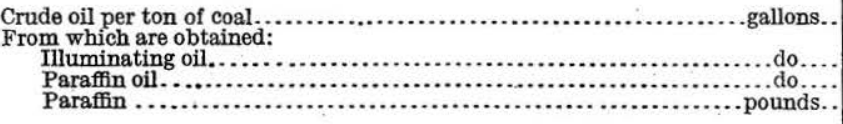 } & 130 & 120 \\
\hline & \multirow{3}{*}{$\begin{array}{r}80 \\
12 \\
\ldots \ldots \ldots \ldots\end{array}$} & \\
\hline & & \\
\hline & & \\
\hline 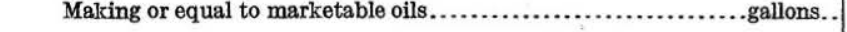 & 92 & 84 \\
\hline
\end{tabular}

$a$ Gesner, Abraham, Practical treatise on coal, petroleum, and other distilled oils, 2d ed., p. 55, 1865.

For example, Newcastle, England, cannel coal gives very different results, according to whether it is distilled for gas or for oil. The following products are reported by Gesner: ${ }^{1}$

Products per ton of distillation of Newcastle, England, cannel coal distilled for gas and for oil.

\section{Distilled for gas.}

Coal gas

Coal tar

Coke.

Products of the coal tar:

Benzole.

Coal-tar naphth

Heavy oil, naphthalin, etc.......do.... cubic feet.. 7,450 gallons.. 181 ...pounds.. 1, 200 ...pints.. 3 $\frac{9}{12 \frac{2}{3}}$
Distilled for oil.

Gas.............................cubic feet.. 1, 400

Crude oil.........................gallons.. . 68

Coke........................... pounds.. 1, 280

Products of the crude oil:
Eupion.....................gallons.. . $\quad 2$

Lamp oil........................... 22.5

Heavy oil and paraffin...........do.... 24

${ }^{1}$ Gesner, Abraham, Practical treatise on coal, petroleum, and other distilled oils, 2d ed., p. 110, 1865 . 
Gesner reports the following series of hydrocarbons as derived from Breckinridge cannel coal when distilled at an average heat of $780^{\circ}: 1, \mathrm{C}_{4} \mathrm{H}_{2}$ (supposed to exist but not condensed); $2, \mathrm{C}_{6} \mathrm{H}_{4}$; $3, \mathrm{C}_{8} \mathrm{H}_{6} ; 4, \mathrm{C}_{10} \mathrm{H}_{8} ; 5, \mathrm{C}_{12} \mathrm{H}_{10} ; 6, \mathrm{C}_{14} \mathrm{H}_{12} ; 7, \mathrm{C}_{16} \mathrm{H}_{14} ; 8, \mathrm{C}_{18} \mathrm{H}_{18} ; 9$, $\mathrm{C}_{20} \mathrm{H}_{18} ; 10, \mathrm{C}_{22} \mathrm{H}_{20}$; paraffin (3-9 are stated as "embracing the hydrocarbon oils suitable for lamps when mixed"); specific gravity, 0.819." "A coal from Kanawha, Va. [W. Va.], when distilled at a heat of $900^{\circ}$ gave part of a series thus: $1, \mathrm{C}_{8} \mathrm{H}_{4} ; 2, \mathrm{C}_{12} \mathrm{H}_{8} ; 3, \mathrm{C}_{16} \mathrm{H}_{12}$; 4, $\mathrm{C}_{18} \mathrm{H}_{18} .{ }^{2}$

The following table by Porter ${ }^{3}$ shows the substances derived from tar at different temperatures:

Fractions of average coal tar and their uses.

\begin{tabular}{|c|c|c|c|c|}
\hline $\begin{array}{r}\text { Temperature of distil- } \\
\text { lation ...................... }\end{array}$ & $70^{\circ}-160^{\circ} \mathrm{C}$. & $160^{\circ}-230^{\circ} \mathrm{C}$. & $230^{\circ}-360^{\circ} \mathrm{C}$. & Above $360^{\circ} \mathrm{C}$. \\
\hline $\begin{array}{l}\text { First crude separation } \\
\text { by distillation. }\end{array}$ & Light oil.... & $\begin{array}{l}\text { Middle oil (or dead } \\
\text { oil). }\end{array}$ & $\begin{array}{c}\text { Heavy oil (includ- } \\
\text { ing anthracene }\end{array}$ & Pitch. \\
\hline ge in $\operatorname{tar} . . . .$. & & & $24 \ldots \ldots$ & \\
\hline $\begin{array}{l}\text { Intermediate products } \\
\text { by distillation or ex- } \\
\text { pression. }\end{array}$ & $\begin{array}{l}\text { Benzene, toluene, } \\
\text { xylene, e t c.; } \\
\text { phenol. }\end{array}$ & $\begin{array}{l}\text { Phenol, cresols, } \\
\text { etc., naphtha- } \\
\text { lene, heavy hy- } \\
\text { drocarbons. }\end{array}$ & $\begin{array}{l}\text { Cresols, naphtha- } \\
\text { lene, a n t hr a- } \\
\text { cene, heavy hy- } \\
\text { drocarbons, qui- } \\
\text { noline bases. }\end{array}$ & $\begin{array}{l}\text { Soft pitch, hard } \\
\text { pitch. }\end{array}$ \\
\hline $\begin{array}{l}\text { Crude com mercial } \\
\text { products. }\end{array}$ & $\begin{array}{l}\text { Benzol and sol- } \\
\text { vent naphtha } \\
\text { for solvents, } \\
\text { paint thinners, } \\
\text { motor fuel, gas } \\
\text { enrichment. }\end{array}$ & $\begin{array}{r}\text { Creos } \\
\text { Lamp } \\
\text { Disinfectants...... }\end{array}$ & $\begin{array}{l}\text { ote oil. } \\
\text { black. } \\
\text { Road oils, impreg- } \\
\text { nation of timber. } \\
\text { Roofing } \\
\text { Paving }\end{array}$ & $\begin{array}{l}\text { Pttch, briquetting } \\
\text { protective. } \\
\text { tars. } \\
\text { tars. }\end{array}$ \\
\hline $\begin{array}{l}\text { Intermediate chemical } \\
\text { products. }\end{array}$ & $\begin{array}{l}\text { Nitro ben zene, } \\
\text { aniline s alt s, } \\
\text { aniline oil, car- } \\
\text { bolic acid. }\end{array}$ & $\begin{array}{l}\text { Carbolic acid, pic- } \\
\text { ric acid, phtha- } \\
\text { lic acid, naph- } \\
\text { thols, naphthy- } \\
\text { lamines, salicy- } \\
\text { lic acid. }\end{array}$ & $\begin{array}{l}\text { Anthra qui n one } \\
\text { alizarin. }\end{array}$ & . \\
\hline $\begin{array}{l}\text { Refined chemical prod- } \\
\text { ucts. }\end{array}$ & $\begin{array}{l}\text { Nitrotoluenes, di- } \\
\text { phenyla m in e, } \\
\text { and other in- } \\
\text { gredients of ex- } \\
\text { plosives; aniline } \\
\text { dyes; hydro- } \\
\text { quinone, and } \\
\text { other ph o t o- } \\
\text { graphio devel- } \\
\text { opers; drugs and } \\
\text { medicines. }\end{array}$ & $\begin{array}{l}\text { Picric acid, pic- } \\
\text { rates, and other } \\
\text { n i t r o - c o m- } \\
\text { pounds for ex- } \\
\text { plosives; naph- } \\
\text { thol dyes and } \\
\text { colors, artificial } \\
\text { indigo, refined } \\
\text { carbolic acid. }\end{array}$ & Alizarin dyes... & . \\
\hline
\end{tabular}

Light oil or "benzol" may also be obtained directly from coal gas, of which it forms about 1 per cent by weight. In 1913 about 4,500,000 gallons of "gas benzol" was made in addition to that used in gas enriching, and new benzol plants have since largely increased that production. Probably 3,000,000 to 5,000,000 gallons of light oil was obtained from tar in the United States in 1913. It has been estimated that if all the "benzol" were recovered from the coal used in this country for making gas and coke, it would amount to over $100,000,000$ gallons.

1 Gesner, Abraham, op. cit., p. 125.

${ }^{2}$ Idem. p. 126.

s Porter, H. C., Coal-tar products, etc. : Bur. Mines Tech. Paper 89, p. 10, 1915. 
According to Lewes, ${ }^{1}$ if coal gas is scrubbed with creosote oil, it will yield 3 to 4 gallons of crude benzene per ton of coal, containing 20 to 30 per cent of toluol.

Inubishi ${ }^{2}$ has estimated that from the total Japanese yield of 60,000 tons of coal tar there should be obtained 230 tons of benzene, 140 tons of toluene, 200 tons of phenol, 700 tons of cresol, 3,400 tons of refined naphthalene, 8,600 tons of creosote, 7,000 tons of fuel oil, 200 tons of anthracene, and 38,000 tons of pitch.

Experiments in 1915 by the Bureau of Mines gave the following results:

\begin{tabular}{|c|c|c|c|c|}
\hline & $\begin{array}{c}\text { Coke (per } \\
\text { cent). }\end{array}$ & $\begin{array}{l}\text { Tar (gal- } \\
\text { lons per } \\
\text { ton). }\end{array}$ & $\begin{array}{l}\text { Ammonia } \\
\text { (pounds of } \\
\text { sulphate } \\
\text { per ton). }\end{array}$ & $\begin{array}{l}\text { Stripped } \\
\text { oil (gal-. } \\
\text { lons per } \\
\text { ton). }\end{array}$ \\
\hline 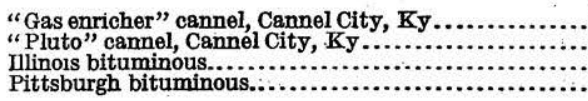 & $\begin{array}{l}48 \\
65 \\
65 \\
70\end{array}$ & $\begin{array}{r}80 \\
35 \\
18 \\
20\end{array}$ & $\begin{array}{r}8 \\
5 \\
13 \\
9\end{array}$ & $\begin{array}{l}5 \\
4 \\
1.5 \\
2.5\end{array}$ \\
\hline
\end{tabular}

Charges, 5 to 8 pounds; maximum temperature $700^{\circ} \mathrm{C}$. "Stripped oil" derived by steam distillation from "straw oil" used in washing gas, as in benzol-recovery plant. Aromatics notably absent from lowboiling tar fractions and "stripped oil."

Analysis of gas from "Pluto" cannel (3,750 cubic feet per ton) showed $\mathrm{CO}_{2}, 4.75$ per cent; ethylene and unsaturated hydrocarbons, $8.50 ; \mathrm{H}_{2}, 24.75 ; \mathrm{CO}, 6.40 ; \mathrm{C}_{\mathrm{n}} \mathrm{H}_{2 \mathrm{n}+2}(\mathrm{n}=1.35), 54.55 ; \mathrm{N}_{2}, 1.05$.

The experiments showed, according to Dr. G. B. Taylor, of the Bureau of Mines, not only that cannel coal differs from other bituminous coals in the larger volumes of tar or oil and gas it yields, but that because of the low temperature at which the liquid products come off they consist mainly of saturated and unsaturated paraffin hydrocarbons, together with tar acids and but little of the valuable benzene and toluene. The low-temperature oils are difficult to refine and as yet have found no ready market. Their possible uses are as flotation oil and as sources of gasoline and creosote. The difficulty in refining for gasoline comes in removing the unsaturated bodies, notably paraffins of the ethylene series. Hydrogenation may in the future obviate this difficulty. Many studies are yet needed of tar and gas derived from cannel coal at high temperature and of the results of "cracking" or other subsequent treatment of the lowtemperature distillation products. ${ }^{3}$

\footnotetext{
${ }^{1}$ Lewes, V. B., The place of the gas industry in the manufacture of modern explosives : Gas World, vol. 62, p. 242, 1915.

2 Inubishi, s., Japanese by-product industry : Gas Age, vol. 35, p. 268, 1915.

${ }^{3}$ Rittman, W. F., The Rittman gasoline process : Nat. Petroleum News, vol. 7, pp. 2-4, 1915. Since the above was written the Bureau of Mines has issued a bulletin by Rittman, Dutton, and Dean (Bull. 114), describing in detail the Rittman and other processes for the cracking of oils and the methods of producing the aromatic hydrocarbons used in making explosives, including a very complete bibliography on these and related subjects.
}

$87775^{\circ}-18-B u l l .659-4$ 


\section{CANNEL-COAL MINING.}

\section{PENNSYIVANIA.}

The early use of cannel coal is largely merged in that of bituminous coal. According to Mansfield ${ }^{1}$ the cannel coal of Cannelton, $\mathrm{Pa}$., appears to have been known to the Indians at least as early as 1750 , and was used by them in their hunting camp at the mouth of Cannel Ravine. William and George Foulks, who were for a time held prisoners by the Indians, seem to have been the first white men to learn its source. It was certainly known to white men in 1787. The first mine was opened by William Welch but was burned out in a raid on horse thieves, who had made the locality a hiding place. It is of record that the cannel mine was purchased in 1820 by James Patterson and operated for two years. When the Pennsylvania \& Ohio Canal was projected in 1831, a survey was made for a "cannel-coal railway" from New Galilee to Newcastle. Though often the subject of ownership disputes, the cannel coal at this point appears to have been worked more or less regularly on a small scale. A railroad was built to the mines in 1855 , and from that time mining continued extensively until 1900. (See Pl. IV, A, p. 34.)

\section{OHIO.}

In Ohio cannel coal was mined in the Flint Ridge region at least as early as 1830 and 1840. Data as to the discovery of the other cannel fields in the State were not obtained, but it is believed that most of them have been known and some of them mined from a very early date. The fact that oil refineries existed at Coshocton, Canfield, and Zanesville, Ohio, before 1860 is itself evidence that the neighboring cannel coals were then being mined.

\section{INDIANA.}

In 1837 the American Cannel Coal Co., of Cannelton, Perry County, Ind., was incorporated and began to mine at that point. Cannel coal mining at Cannelsburg, Daviess County, Ind., was begun in 1871 by the Buckeye Cannel Coal Co., and has been continued to the present time.

\section{WEST VIRGINIA.}

In West Virginia, according to Edwards, ${ }^{2}$ cannel coal began to be exploited on Coal River in the early forties through the activity of

1 Mansfield, I. F., Fireclays, coals, and titles of the cannel-coal tract at Cannelton, Beaver County, Pa., p. 27, 1905.

2 Edwards, W. S., Coals and cokes of West Virginia, pp. 96-98, 1892. 
W. N. Peyton. Among the companies engaged were the Virginia Cannel Coal Co., with mines at Peytona, in Boone County; the Western Mining \& Manufacturing Co., with mines at Drawdy Creek near Peytona; the Cannel Coal Co. of Coal River, with mines at Manningville on Little Coal River; and the Coal River \& Kanawha Mining \& Manufacturing Co., with mines at Briar Creek, in Boone County. These companies organized the Coal River Navigation Co., which built eight locks and dams on Coal River and one on Little Coal River, with an average lift of 10 feet, giving 4 feet of water at all seasons. The cannel-coal trade on this river reached a maximum output of about 200,000 tons a year, the coal going mainly to markets on the lower Ohio. During the Civil War-the mines were abandoned, the markets closed, and the neglected locks and dams washed out. After the war the Virginia Cannel Coal Co. was reorganized as the Peytona Cannel Coal Co. The river was redammed, but after 10 years of financially unsuccessful mining the project was abandoned until a railroad should be built up the river.

About the time development began on Coal River cannel coal was discovered on Kanawha River below Smithers Creek by Aaron Stockton, and in the early fifties a refinery was established at Cannelton to extract oil and paraffin from the Stockton bed. Cannel coal began to be mined on Paint Creek in 1857 and was used in an oil refinery established there. Edwards ${ }^{1}$ says that an unsuccessful attempt was made at Forest Hill to manufacture oil from bituminous shale. Cannel coal was discovered on Twelvepole Creek at a much later date, and development did not begin until the construction of the Norfolk \& Western Railroad through that district. These last deposits of cannel coal proved to be very small.

According to Newberry ${ }^{2}$ cannel coal was also known on Mill Creek and on Falling Rock Creek before the war and for a time an oil refinery was operated $1 \frac{1}{2}$ miles above the mouth of Falling Rock Creek.

KENTUCKY.

Just when cannel-coal mining began in Kentucky was not learned. Mather, ${ }^{3}$. writing in 1838, said that a bed of cannel at the mouth of Troublesome Creek, on Kentucky River, was being regularly mined and shipped down the river in flat boats, but he made no mention of mining on Georges Branch or on Quicksand Creek, though it is possible that the coals at those points were being worked at that time or were opened up soon thereafter. In 1837 the Breckinridge cannel, which had been known for several years, was being mined and hauled

\footnotetext{
${ }^{1}$ Edwards, W. S., op. cit., pp. 85-86.

2 Newberry, J. S., Ohio Geol. Survey Rept., vol. 2, pt. 1, Geology, p. 547, 1874.

${ }^{3}$ Mather, W. W., Report on the geological reconnaissance of Kentucky made in 1838 , p. 15,1839 .
} 
to Ohio River, where it sold for the use of steamers at 10 cents a bushel. Trimble, ${ }^{1}$ writing in 1837 , says that it sold in Louisville at that time at 15 cents a bushel. He adds: "The cannel coal of Kentucky River is believed to be superior to any of that species in America, and is evidently superior to the coal imported under that name. * * * Many veins of it have been found on the Kentucky River." Some idea of the extent of the mining of the Breckinridge cannel may be gained from the fact that, writing in 1855 , Owen ${ }^{2}$ mentions measuring sections in rooms off the eighth entry.

The coals mentioned were probably the only cannels that were being mined in Kentucky in 1855 . Other cannels were known, however, and were probably mined in Greenup, Carter, Johnson, and possibly some other counties before 1860 .

\section{PRODUCTION.}

The figures in the following table, showing the production of cannel coal in the United States, ${ }^{3}$ are fairly complete for years since 1902 but not for preceding years. The term "semicannel" in the table is the term used by the mining companies in their reports and does not mean the coal so named in this paper (p. 10).

Production of canncl coal in the United States, in long tons.

\begin{tabular}{|c|c|c|c|c|c|c|c|c|}
\hline & \multicolumn{2}{|c|}{1892} & \multicolumn{2}{|c|}{1902} & \multicolumn{2}{|c|}{1903} & \multicolumn{2}{|c|}{1904} \\
\hline State. & Cannel. & $\begin{array}{l}\text { Semi- } \\
\text { cannel. }\end{array}$ & Cannel. & $\begin{array}{c}\text { Semi- } \\
\text { cannel. }\end{array}$ & Cannel. & $\begin{array}{l}\text { Semi- } \\
\text { cannel. }\end{array}$ & Cannel. & $\begin{array}{l}\text { Semi- } \\
\text { cannel. }\end{array}$ \\
\hline 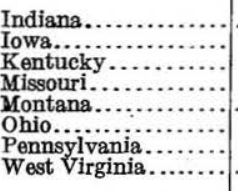 & $\begin{array}{r}1,401 \\
25,383 \\
2,486 \\
27,798 \\
25,920\end{array}$ & 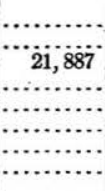 & \begin{tabular}{r}
30,000 \\
15,000 \\
63,717 \\
446 \\
\hdashline,$\ldots 07$ \\
30,905 \\
10,000
\end{tabular} & 'i24,70i & $\begin{array}{r}35,900 \\
19,621 \\
118,616 \\
700 \\
.650 \\
11,154 \\
14,014\end{array}$ & 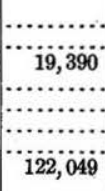 & $\begin{array}{r}32,350 \\
13,127 \\
80,592 \\
7,521 \\
700 \\
8,588 \\
5,807 \\
22,800\end{array}$ & 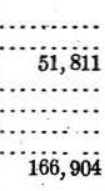 \\
\hline & & 05 & & 06 & & 07 & 19 & \\
\hline State. & Cannel. & $\begin{array}{l}\text { Semi- } \\
\text { cannel. }\end{array}$ & Cannel. & $\begin{array}{c}\text { Semi- } \\
\text { cannel. }\end{array}$ & Cannel. & $\begin{array}{l}\text { Semi- } \\
\text { cannel. }\end{array}$ & Cannel. & $\begin{array}{c}\text { Semi- } \\
\text { cannel. }\end{array}$ \\
\hline Alab & & & & & 14,722 & & & \\
\hline $\begin{array}{l}\text { Indiana. } \\
\text { Iowa.... }\end{array}$ & $\begin{array}{l}32,475 \\
15,612\end{array}$ & (…...... & $\begin{array}{l}25,475 \\
13,020\end{array}$ & & $\begin{array}{l}38,455 \\
10,800\end{array}$ & $\begin{array}{l}\ldots .2,200 \\
\cdots . .2 \ldots\end{array}$ & $\begin{array}{l}30,230 \\
22,718\end{array}$ & \\
\hline $\begin{array}{l}\text { Kentucky..... } \\
\text { Missouri...... }\end{array}$ & $\begin{array}{r}138,408 \\
2,500\end{array}$ & $\begin{array}{r}15,397 \\
\ldots \ldots \ldots \ldots\end{array}$ & $\begin{array}{r}73,083 \\
5,100\end{array}$ & 4,650 & $\begin{array}{r}97,586 \\
1,859\end{array}$ & ….......... & $\begin{array}{r}82,933 \\
4,183\end{array}$ & $6,20 \mathrm{i}$ \\
\hline Mont & 150 & & & & & & & \\
\hline zania......... & 2,362 & .... & 3,836 & .... & 400 & $\cdots \cdots$ & 865 & \\
\hline $\begin{array}{l}\text { Pennsylvania......... } \\
\text { Texas.................. }\end{array}$ & $\begin{array}{r}3,819 \\
78,500\end{array}$ & & 6,160 & & $\begin{array}{r}14,772 \\
2,200\end{array}$ & & 24,307 & \\
\hline West Virginia ....... & 18,167 & 238,844 & 14,480 & $\ldots$ & 13,681 & an........... & $\ddot{64}, 369$ & ........ \\
\hline
\end{tabular}

${ }^{1}$ Trimble, D., Report of the committee on the coal trade and iron interests of Kentucky, p. 3 [1837?].

${ }^{2}$ Owen, D. D., Kentucky Geol. Survey Rept. for 1854 and 1855, p. 175, 1856.

${ }^{3}$ U. S. Geol. Survey Mineral Resources. 
Production of cannel coal in the United States, in long tons-Continued.

\begin{tabular}{|c|c|c|c|c|c|c|c|c|}
\hline \multirow[b]{2}{*}{ State. } & \multicolumn{2}{|c|}{1909} & \multicolumn{2}{|c|}{1911} & \multicolumn{2}{|c|}{1912} & \multicolumn{2}{|c|}{1913} \\
\hline & Cannel. & $\begin{array}{l}\text { Semi- } \\
\text { cannel. }\end{array}$ & Cannel. & $\begin{array}{c}\text { Semi- } \\
\text { cannel. }\end{array}$ & Cannel. & $\begin{array}{l}\text { Semi- } \\
\text { cannel. }\end{array}$ & Cannel. & $\begin{array}{l}\text { Semi- } \\
\text { cannel. }\end{array}$ \\
\hline Indiana. & 22,676 & ........ & 11,875 & & 7,373 & & & \\
\hline $\begin{array}{l}\text { Jowa..................................... } \\
\text { Kentucy. }\end{array}$ & $\begin{array}{l}21,672 \\
67,869\end{array}$ & 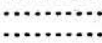 & 90,275 & $\cdots$ & $\begin{array}{r}8,344 \\
88,292\end{array}$ & $\cdots 86,377$ & $\begin{array}{r}5,628 \\
90,124\end{array}$ & 86,263 \\
\hline Missouri................ & $\begin{array}{r}5,936 \\
2078\end{array}$ & & $\ldots \ldots$ & $\cdots \cdot$ & 3,583 & ............. & 3,931 & -........... \\
\hline Ohio ....................... & $\begin{array}{l}33,778 \\
51,347\end{array}$ & 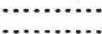 & $\begin{array}{r}5,683 \\
39,879\end{array}$ & an. & $\begin{array}{r}4,039 \\
68,091\end{array}$ & 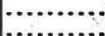 & $\begin{array}{r}5,994 \\
58,174\end{array}$ & 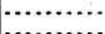 \\
\hline Tennessee................... & & & 8,048 & ........... & 12,500 & $\cdots$ & 6,703 & (n) \\
\hline IVest Virginia... & 119,844 & 121,000 & 14,250 & $\ldots . .$. & 28,848 & 206,585 & 10,303 & $\cdots \cdots \cdot$ \\
\hline
\end{tabular}

The following mines have recently been operating on cannel coal. Those marked.with a * were not reported as operated in 1916.

Indiana :

Mutual Coal Co., Cannelsburg; Mutual mine.* Iowa :

Webster County-Craig \& Dawson Coal Co., Fort Dodge; Cannel No. 2 mine. Kentucky :

Bell County-Federal Coal Co., Chattanooga, Tenn: ; Wallsend, Chenoa.

Carter County-Eastern Kentucky Railway Co., Riverton; Boghead mines.*

Floyd County-Puritan Cannel Coal Co., Prestonburg.

Greenup County-Eastern Kentucky Railway Co., Riverton; Hunnewell mine.*

Harlan County-Cumberland Cannel Coal Go., Welch, W. Va.; No. 1 mine.

Johnson County-

East Kentucky Coal Co., East Point.*

Ayers \& Lang, Detroit, Mich.

Greasy Creek Coal Co., Thealka.

Whitehouse Cannel Coal Co., Myrtle.*

Knox County-North Jellico Coal Co., Lewisville; Olive Hill mine.

Morgan County-

American Consolidated Cannel Coal Co., Loveland; No. 1 mine.*

Bigstaff Cannel Coal Co., Cannel City ; Bigstaff mine.*

Caney Cannel, Coal Co., Paris ; Caney mine.*

Gish Cannel Coal Co., Central City; White Oak mine.

Kentucky Block Cannel Coal Co., Cannel City; No. 1 and Brushy mine.

Lee Cannel Coal Co., Clearfield; Lee No. 1 mine.

Mayflower Cannel Coal Co., Lancaster; Eureka mine.*

Charter Coal Co., Frankfort; Nos. 1 and 2 mines.

Orley Hanley, White Oak; Little mine.

Whitley County-Halsey Red Ash Coal Co., Halsey ; Anderson and Vanderpool mines.

Missouri :

Callaway County-W. C. Weeks.

Cole County-S. \& A. Bandelier, Elston.*

Moniteau County-

Monarch Coal \& Mining Co., Excelsior.*

Rohrbach-Rowlin Mining Co.*

Newkirk Mining Co.*

Morgan County-Hubbard \& Moore.* 
Ohio:

Coshocton County-

Dailey Cannel Coal Co., Mohawk Village; Dailey mine.*

Ohio Block Cannel Coal Co., Toledo; Flambo mine.

Ohio Cannel Coal Co., Coshocton; Ohio mine.

Mahoning County-American Fire Clay Co., Cleveland.

Pennsylvania :

Butler County-Butts Cannel Coal Co., Deegan.

Center County-Lula Coal Mining Co., Philipsburg; Lula mine.

Clearfield County-

A. Stolz, Houtzdale; Katherine mine.

Hurley, Wilson \& Law, Houtzdale; Keystone mine.*

A. B. Lansberry, Woodland; Mines Nos. 2 and 3.

Woodland Cannel Coal Co., Woodland; Cannel Crest.

Washington Jury, Woodland.

Indiana County-Altoona Coal Co.

Armstrong County-

Fairmont Coal Co., Buffalo, N. Y.; Mines Nos. 8 and 9, Bostonia:

Pine Run Coal Co., New Bethlehem; Brooks No. 1 and Cooke.

Westmoreland County-W. E. Brown \& Co., Ligonier; Darlington mine. Tennessee:

Campbell County-Jellico Cannel Coal Co., Massillon, Ohio; Hermitage mine.*

Texas:

Webb County-

Santo Tomas Coal Co., Santo Tomas.

Cannel Coal Co., Dolores.

West Virginia:

Boone County-Peytona Block Coal Co., Peytona; Cannel mine.

Kanawha County-

Paint Creek Collieries Co., Scranton, Pa.; Wacomah mine.*

Mill Creek Cannel Mining Co., Cleveland, Ohio; Mill Creek.

Weirwick Cannel Coal Co., Weir.*

Wayne County-Wells Branch Coal Co., Wells Branch.

\section{VALUE.}

The natural auestion arising in the mind of anyone thinking of buying cannel coal is why it is so expensive. Dotubtless the principal reason is the well-known law of supply and demand. The total supply of cannel coal is very small, and the coal is distributed in small basins or pockets, hardly any of which would pay for the installation of a modern mining plant of any size, even at present prices of cannel coal. Most of the deposits are not closely adjacent to railroad transportation and are not extensive enough in themselves to warrant building a spur of any length. Further, the demand for use in grates, the principal demand in recent years, has been for coal in blocks, so that the fine coal necessarily made in mining has not found a market. If the distillation of cannel coal for oil and other by-products is resumed all the coal will find a market, but the increased demand is as likely to raise the general price as to lower it. In many of the basins, by careful hand mining, the whole 
product may be gotten out in block form. In others the wastage, because of the restricted demand of the market, may be as high as one-half. The whole product (including the slack) of coals rich in gas, or those having 50 to 60 per cent of volatile matter and a correspondingly high candlepower, will always find a readier market, while the drier cannels and semicannels will find a more restricted market for the blocks only and will therefore have a correspondingly larger percentage of waste.

The labor cost of cannel coal, f. o. b. cars at the mine, should not, as a rule, be more than $\$ 1$ per ton of total product. ${ }^{1}$ If only one-half of the product can be marketed the marketed coal must bear the cost, or, say, $\$ 2$ per ton. Where the mines have no railroad connection the cost of hauling to the railroad must be added to the other costs of mining. In some fields containing the richer cannels the miners are paid high prices for mining. At one place visited by the writer the miners were receiving $\$ 2.50$ a ton, besides being given a bench of bituminous coal associated with the cannel. The mine, however, was a small one, and the miner not only mined his coal but pushed it out to the tipple and attended to all the handling it received until it was placed on the cars. As the cannel being mined was very rich and brought a high price, well above the average of other cannels, the owner could doubtless well afford the price he paid. In other places the methods of mining and of transportation are very expensive, involving, for instance, the frequent handling of the coal by hand, as large bricks might be handled. (See Pl. I, p. 12.)

The selling price of cannel at the mines is usually about double that of bituminous coal in the same district. Thus, in 1904 true cannel coal in Kentucky was bringing from $\$ 1.97$ to $\$ 2.49$ at the mines as against 80 cents to $\$ 1.50$ for bituminous coals. Cannel coal in the Clearfield district of Pennsylvania was bringing $\$ 1.80$ to $\$ 2$ as compared to 89 cents to $\$ 1$ for bituminous coals of the same district. Ohio cannels brought $\$ 3.25$ as compared with $\$ 1.20$ to $\$ 1.80$ for bituminous coals in the same district. West Virginia cannel brought $\$ 2.23$ as against 80 cents to $\$ 1.32$ for bituminous coals.

Most of the mine inspector's reports for Kentucky give the selling price of cannel coal at the mine. The following table gives the selling prices of cannel and bituminous coals for selected years:

Selling prices per ton of cannel and bituminous coals in Kentucky.

\begin{tabular}{|c|c|c|c|c|c|c|}
\hline Yesr. & 1903 & 1904 & 1905 & 1906 & 1907 & 1911 \\
\hline 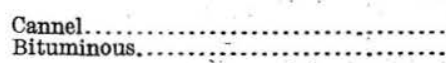 & $\$ 2.40$ & $\begin{array}{r}\$ 2.03 \\
.98\end{array}$ & $\begin{array}{r}\$ 2.44 \\
.97\end{array}$ & $\begin{array}{r}\$ 2.40 \\
1.00\end{array}$ & $\begin{array}{r}\$ 2.60-3.25 \\
1.05\end{array}$ & $\begin{array}{r}\$ 2.51 \\
.98\end{array}$ \\
\hline
\end{tabular}

1 Under pre-war conditions. 
According to the Coal Trade Journal for 1910, American carnel coals sold in New York that year at $\$ 13$ to $\$ 14$ a ton and imported cannels at $\$ 16$ to $\$ 17$ a ton. Prices in Chicago and other places having a shorter freight haul were correspondingly lower.

\section{DISTRIBUTION.}

\section{PENNSYLVANIA.}

REVIVAL OF THE INDUSTRY.

Cannel coal has long been mined (see p. 50) in Pennsylvania at Cannelton, in Beaver County, and at different times in Armstrong, Indiana, and Clearfield counties. (See Pl. V.) In 1914 the writer made a special trip through the Pennsylvania coal field, visiting or revisiting nearly or quite all of the cannel-coal mines then operating in the State. At that time he was surprised to find that several of the old mines had been reopened and were being operated extensively and that one country mine, formerly visited, was being opened up on a commercial scale, involving the building of a narrow-gage tram road several miles long. The special purpose of the writer's trip was to obtain specimens for testing for the production of oil. (See pp. 45-46.) In the following pages most of the deposits described are, or have been, or give promise of becoming commercial propositions. All the cannel coal in Pennsylvania, except that in Beaver County and one or two other places, appears to be semicannel.

\section{CENTER COUNTY.}

Philipsburg.-A bench of semicannel or canneloid coal occurs in the B bed, where mined by the Lula Coal Mining Co. about a mile southwest of Philipsburg (location $2^{1}$ ). When visited, it was estimated that at least 100 acres, and possibly several times that area, under the wide creek bottoms was underlain by about 4 feet of cannel lying between two benches of bituminous coal. The cannel is 4 feet thick in part of the mine, but to the southeast it pinches down to 5 inches or less. To the north and west it runs out under the broad creek bottoms and is reported to have been struck in a well on the west side of the valley. Where it is thick the upper bench of bituminous coal (27 inches thick) is undercut and the cannel is raised. Where it is thin the whole bed is undercut by electrical machines. (See fig. 2, section 1.) The cannel gives an abundant white ash, ranging probably from 15 to 20 per cent. (See also pp. 12, 13.)

${ }^{1}$ Location numbers for Pennsylvania appear on Plate V. 


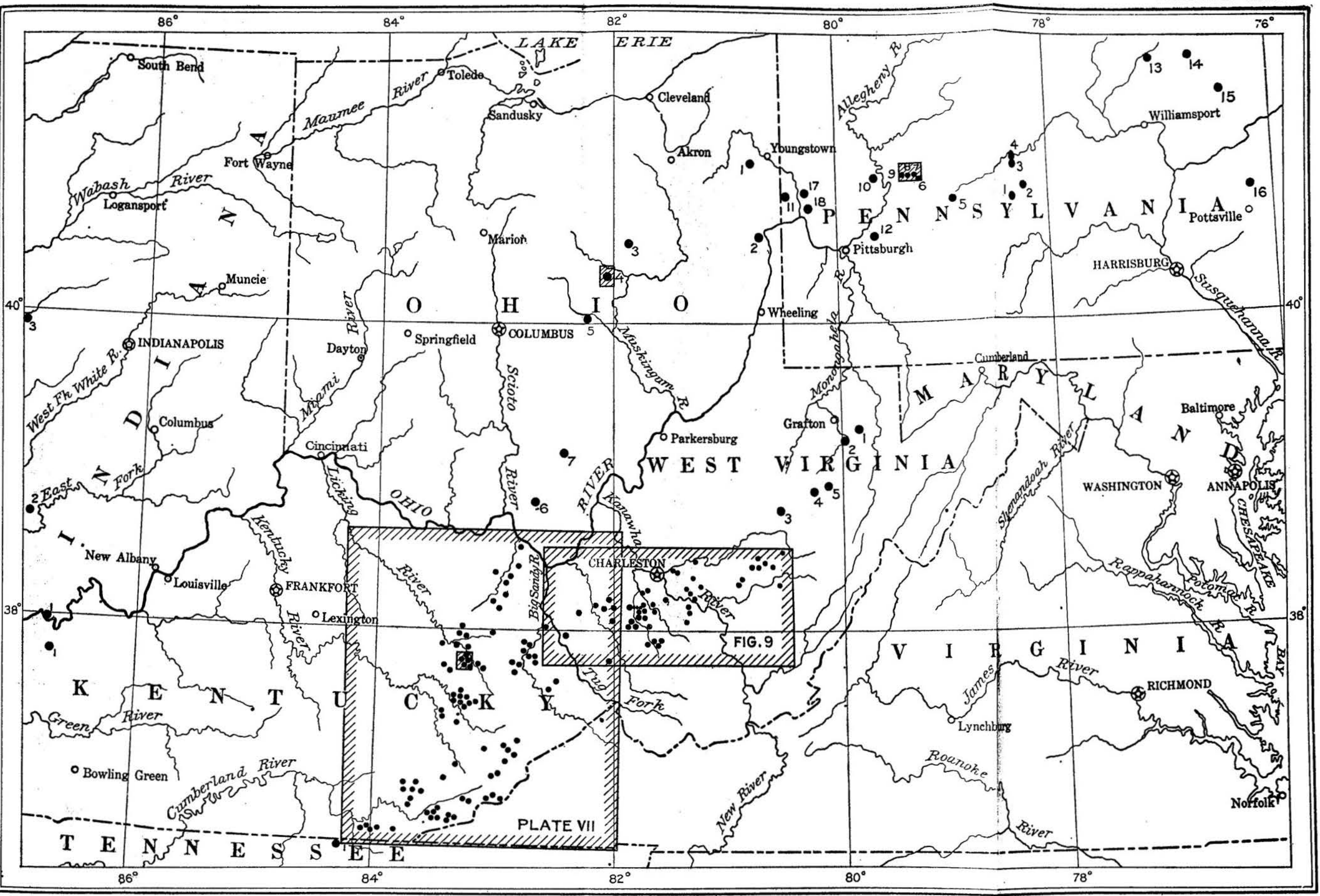

$\begin{array}{lllllllll}25 & 0 & 25 & 50 & 75 & 100 & 125 & 150 & 175\end{array}$

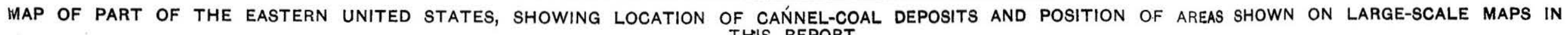
Numbered localities separate deposits not included in large-scale maps but described in text. Separate series of numbers for each State. 

Moshannon Creek.-A small basin of cannel coal occurs on Moshannon Creek (location 1) just above the mouth of Whiteside Run, a few miles southeast of Houtzdale. It has been mined at the Kath-

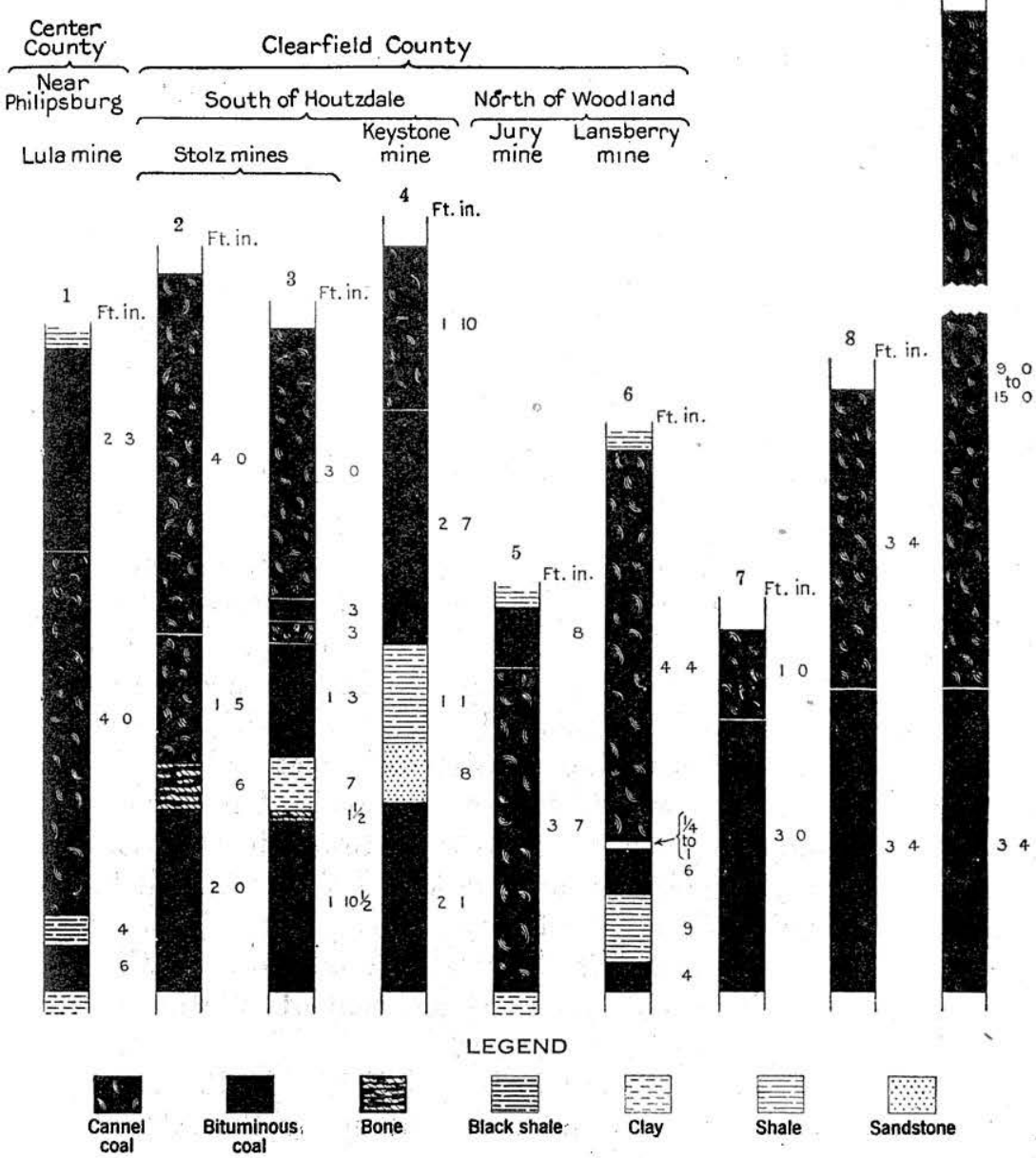

Figdre 2.-Sections of cannel coal in Center, Clearfield, and Indiana counties, Pa.

erine mine of A. Stolz and at the Keystone mine of Hurly, Wilson \& Law. The cannel portion of the bed has a maximum thickness of 4 feet and is associated with $2 \frac{1}{2}$ feet or less of bituminous coal. The extent of the bed is not known, but the variability of cannel beds at 
points not far distant indicates that it is probably not over a few. hundred acres. (See fig. 2, sections 2-4.)

Woodland.-Cannel coal was formerly mined in the hills immediately north of Woodland and is still being mined $1 \frac{1}{2}$ miles north of that town (locations 3 and 4 ). In the hills two beds formerly mined were known as the red-ash cannel and the white-ash cannel (correlated as the $\mathrm{C}^{\prime}$ or Upper Kittanning and the $\mathrm{C}$ or Middle Kittanning coals). The coal reached a maximum of 4 feet just north of the east end of town. Whether this basin extends northward to the area in which mining is now being done is not known. Probably it does not, though considerable cannel may lie between the two points.

One and one-half miles north of Woodland cannel coal is being mined by A. B. Lansberry and, for wagon trade, by Washington Jury. The Lansberry mine is connected by tram with the New York Central Railroad near the tunnel 5 miles below Clearfield, on Susquehanna River. Several openings have been made on the coal, which shows about 4 feet of cannel, associated with a small amount of bituminous coal. (See fig. 2, sections 5, 6.) In this cannel, as in that at Lula, the fracture is not typical but resembles that of the bituminous coals of the region.

\section{INDIANA COUNTY.}

Richmond.-Rather thick beds of cannel coal have been opened at several places south of Richmond (location 5), a station south of Punxsutawney on the Indiana branch of the Buffalo, Rochestęr \& Pittsburgh Railway.

At one opening the Altoona Coal Co. was, in 1914, making preparations to ship cannel coal commercially. The bed, which is correlated as the $\mathrm{C}^{\prime}$ or Upper Kittanning, consists of 3 feet or less of bituminous coal overlain by from 1 to 15 feet of cannel. The cannel part of the bed is thought to occupy a narrow north-south basin extending southward from this point toward Deckers Point, where it has been mined on a small scale on the George Barr place. It has the appearance of a true cannel, but chemically it is a low-volatile cannel or semicannel, showing only 23 to 24 per cent of volatile matter in contrast with 30 per cent in the underlying bituminous coal. At the Barr opening the cannel portion of the bed is only 15 inches thick, and at the old Lowry mine, later opened up by the Altoona Coal Co., it was seen to change from 9 feet to 1 foot in a very short distance. ${ }^{1}$ (See fig. 2, sections 7-9; and analyses 166, 167, p. 27.)

${ }^{1}$ Platt, W. G., Report of progress in Indiana County : Pennsylvania Second Geol. Survey Rept. H4, pp. 228-231, 1878. 
WESTMORELAND COUNTY.

The Pittsburgh coal bed carries a little cannel coal in many places in Westmoreland County, and at many more is overlain by cannel shale. Stevenson ${ }^{1}$ says that in Burrwell Township, 2 miles west of McLaughlin (locality 12), the top bench of the Pittsburgh coal carries 4 to 10 inches of cannel.

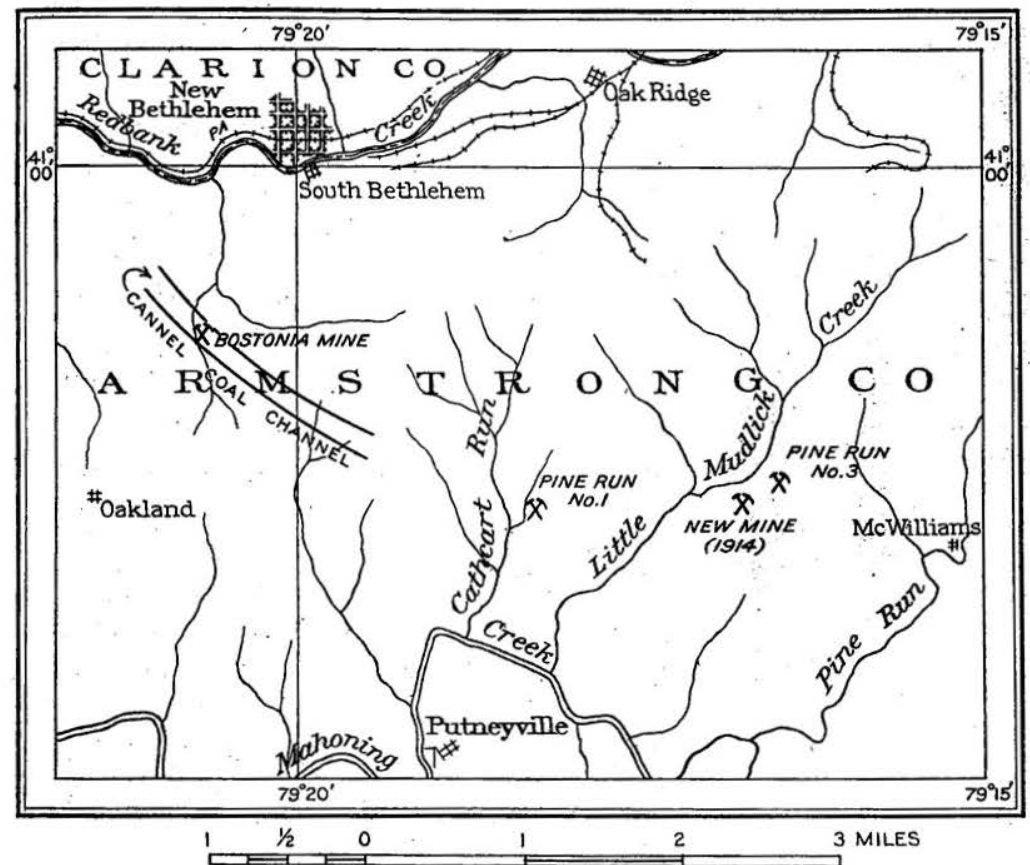

FIGURE 3.-Sketch map of area of cannel coal south of New Bethlehem, Armstrong County, $\mathrm{Pa}$.

\section{ARMSTRONG COUNTY.}

South of New Bethlehem.-In 1914 most of the cannel coal mined in Pennsylvania came from a small district south of New Bethlehem (locations 6-9) on the low-grade division of the Pennsylvania Railroad. Cannel coal was mined'by the Fairmont Coal Co. at Bostenia (location 9), $1 \frac{1}{2}$ miles south of New Bethlehem, and by the Pine Run Coal Co. on Cathcart Run, and on Little Mudlick Creek. (See fig. 3.)

The coal being mined is the $\mathrm{C}^{\prime}$ or Upper Kittanning. The cannel coal appears to lie in a narrow basin, whose axis extends northwestward across the head of a small ravine emptying into Redbank Creek just below New Bethlehem. In the Bostonia mine the maximum

${ }^{1}$ Stevenson, J. J., Pennsylvania Second Geol. Survey Rept. K2, p. 369, 1877. 
minable width of the basin is about 800 feet. In the center there is 9 feet of cannel over 18 inches of bituminous coal. The channel, here nearly straight, had in 1914 been mined out for 2,000 feet to the northwest and 5,300
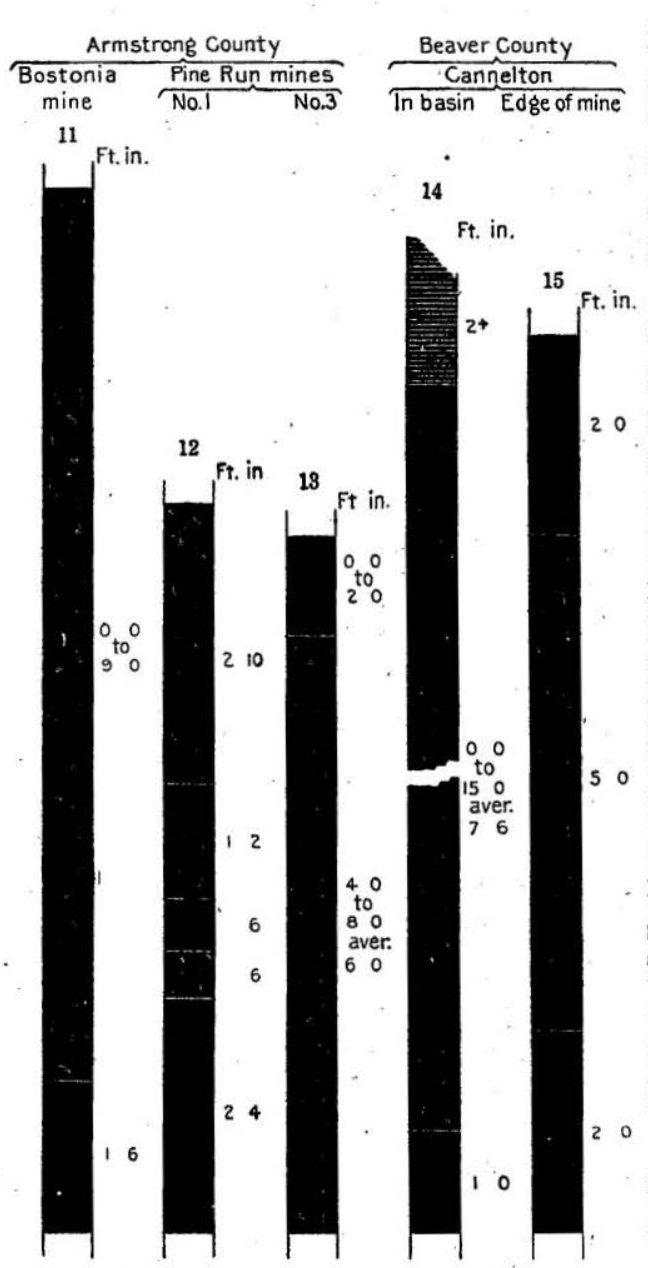

12

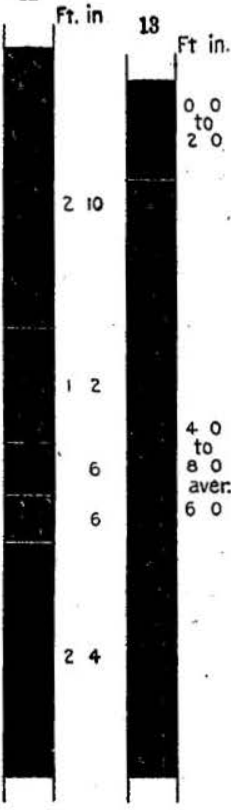

LEGEND
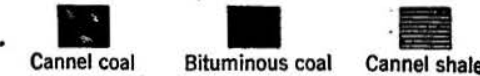

Figure 4.--Sections of cannel coal in Armstrong and Beaver counties, $\mathbf{P a}$.

feet to the southeast of the ravine crossing nearly halfway through the divide between the mine and Cathcart Run. ' (See fig. 4, section 11.)

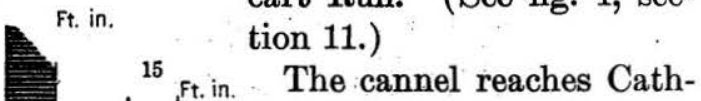
${ }^{2+}-\quad$ cart Run about a mile from the mouth and is being 20 mined on the east side at mine No. 1 of the Pine Run Coal Co. (location 8). From there the channel runs eastward, rea ching Little Mudlick Creek, nearly 2 miles from the mouth. In 1914 cannel coal was being mined at No. 3 mine of the Pine Run Coal Co. (location 7), and a new mine was being opened a short distance to the south. The same bed has been opened up again east of Charleston on the Jacob Schiech farm (location 6). At the Pine Run No. 1 mine, on Cathcart Run, the cannel coal (analysis 162, p. 26) is in two benches, the upper from less than 3 feet to more than 5 feet thick and the lower from 6 inches to 7 feet thick, separated by 12 to 20 inches of "mixed" coal, all underlain by 2 feet or more of bituminous coal. The mixed coal bench has 6 inches of bituminous coal at the bottom and the rest is "curly" cannel, with possibly streaks of bituminous. Both the cannel and bituminous coal here are irregular, for as the cannel thins the bituminous coal thickens, reaching 5 feet at the back of the mine. 
At the Pine Run No. 3 mine the cannel is 4 to 8 feet thick (averaging about 6 feet) and is overlain in most places by bituminous coal of a maximum thickness of 2 feet. In places a little bituminous coal is found under the cannel. The cannel runs out in entries to the north but holds its thickness in those to the east. The new opening, a short distance to the south, appears to be in a branch of the channel from the south, for the cannel thins to the east but holds up to 7 feet southward. At all of these mines a considerable portion of the mined coal, though possibly suitable for making oil, does not meet the trade demand which calls for a smooth even block. Even the amount of oil in these cannels is small, as shown by the tests and analyses. (See fig. 4, sections 11-13, and analyses $160-163$, p. 26.)

The channel is nearly straight at the Bostonia mine, but to the southeast it appears to become crooked and irregular and probably divides into branches. Whether the several channels so far located connect and form parts of the same channel or system of channels is not certain. Search has not yet revealed cannel coal on the west side of Pine Run or Little Mudlick Creek. The cannel-coal channels found appear to belong to the same system.

The cannel coal lies in a channel distinctly depressed in the middle. (See p. 32.) The coal bed is much broken up by slips or cracks filled with clay, sandstone, or sulphur. Some of these are nearly vertical and some are irregular, ranging in width from next to nothing to 16 feet. These clay slips interfere greatly with mining the coal into dimension blocks (as they would be called in the stone industry); and as the trade demands mainly coal in that form it has been necessary to "gob" or store outside about half of the product of the mine. In some places these clay "veins" have been pierced by drillings, making it appear that the coal bed was absent at that point.

Somerville.-Near Somerville, in the northwest corner of Armstrong County (location 10), the Upper Kittanning is locally 2 to 12 feet thick, comprising 2 to 5 feet of bituminous coal underlain by a maximum of 7 feet of low-grade cannel. It has been mined at the Ganner mine. The coal here occurs, as in many other places, in narrow, irregular depressions or concavities. Beyond the limits of the depression the bed is locally scarcely more than a streak in the rocks. Its occurrence at the Ganner mine is described by Platt ${ }^{1}$ as follows :

A good exhibition of its cannel-slate feature may be had at the Ganner mine in the ravine of Holder Run, at which place the bed is 2 feet thick at the outcrop, increasing within a short distance to 5 feet of bituminous coal of a fairly good quality. The floor of the seam then rapidly descends at an angle of $10^{\circ}$

1 Platt, W. G., Report of progress in Armstrong County: Pennsylvania Second Geol. Survey Rept. H5, p. 222, 1880. 
to a depth of 7 feet, the roof mainly remaining horizontal. The interval between is gradually occupied by a mass of impure cannel slate of a dull luster and having conchoidal fracture.

\section{ALLEGHENY COUNTY.}

In Allegheny County the Pittsburgh bed carries at its top 2 feet of impure cannel at the Brewer bank and the Upper Freeport coal a similar thickness around Hiteston, both in West Deer Township. ${ }^{1}$ The Elk Lick coal carries 6 to 12 inches of cannel at several places, as in Reserve and McClure townships and on Duff Run, in Franklin Township. ${ }^{2}$ Near Allegheny City the Elk Lick coal is represented by 1 to 2 feet of cannel or cannel shale, and at Bakerstown the Bakerstown coal carries 6 to 12 inches of cannel at its base. ${ }^{3}$

\section{BUTLER COUNTY.}

A little cannel coal has been found at several places in Butler County. On Breakneck Creek, in Adams Township, 4 to 6 inches of cannel lies at the top of the Upper Freeport. ${ }^{4}$ A thin bed of cannel lies at the top of the Bakersfield coal near the head of the south branch of Glade Creek, in Middlesex Township, and another lies at the horizon of the Mahoning coal in Forward Township. ${ }^{5}$ In Jackson Township along Breakneck Creek $^{8}$ the Lower Freeport carries a foot or more of cannel. In Lancaster Township on Yellow Creek $^{7}$ a coal thought to be below the Lower Freeport carries 1 foot of cannel and 3 feet 4 inches of bituminous coal that has a semicannel structure.

\section{BEAVER COUNTY.}

The famous Cannelton bed in the northwest corner of Beaver County, north of Cannelton (location 11), appears to occupy an old channel. It consists of three parts, a bench of bituminous coal 6 to 12 inches thick at the bottom overlain by 6 to .12 or more feet of cannel coal, which grades upward into a rich cannel shale, in places 6 feet in thickness. The bituminous coal at the bottom is interlaminated with streaks of cannel. The channel has a width of about 600 feet. For a width of 300 feet in the center the coal maintains a

\footnotetext{
1 White, I. C., Report of progress in the Beaver River district: Pennsylvania Second Geol. Survey Rept. Q, pp. 148, 150, 1878.

2 Idem, p. 173.

Idem, pp. 28, 32.

${ }^{4}$ Idem, p. 75.

' Idem, pp. 78, 106.

Idem, pp. 114-115.

7 Idem, p. 121.
} 
good thickness, averaging 7 or 8 feet and ranging up to double that. At the edges of the 300-foot channel the coal averaged 6 feet, but outside of that the sides of the channel rose abruptly to a height in places 20 feet above the bottom of the basin and the coal thinned against the sides and almost or quite pinched out at the top. Mining has shown that the cannel follows an oval course, with a maximum diameter of 2 miles and a minimum diameter of 1 mile. (See fig. 4, sections 14,15 , and analyses 164,165, p. 27.)

In South Beaver Township the Darlington coal is overlain by 10 to 15 inches of cannel, grading into 4 to 5 feet of cannel shale. ${ }^{1}$ In Industry Township the Kittanning coal carries in places as much as $1 \pm$ inches of cannel at its base. ${ }^{2}$ In Economy Township the shale just above the Upper Freeport coal locally takes on the appearance of cannel. Opposite Beaver Falls (location 18) a local bed of cannel in the Freeport sandstone reaches a thickness of 5 feet but has a length of only a few rods. ${ }^{3}$ In North Sewickley Township the Brush Creek coal becomes at one point a bed of cannel reported as 5 feet thick and fairly good, and at another point, on a tributary of Brush Creek (location 17), carries 4 feet of good cannel overlain by 1 foot of shaly cannel and underlain by 1 foot of bituminous coal. ${ }^{4}$ In Marion Township the Darlington coal is overlain by 2 feet of cannel or cannel shale on Brush Creek. ${ }^{5}$ In Pulaski Township on Trough Run the Lower Freeport is locally impure cannel coal 3 feet, thick. $^{6}$ North of that in New Sewickley Township the Darlington coal carries 6 inches of cannel on Cow Run. ${ }^{7}$

oHIO.

Much cannel eoal occurs in Coshocton, Jackson, Licking, and Mahoning counties, Ohio ( $\mathrm{Pl}: \mathrm{V}, \mathrm{p} .56)$, but none of it runs as high as 50 per cent in volatile hydrocarbons. (See analyses 141, 142, $149-157$, p. 26.)

MAHONING COUNTY.

The most important bed in Mahoning County is the No. 4 or "cannel seam," which, according to Newberry, ${ }^{8}$ contains 6 feet of cannel of good quality. In the southwest corner of Canfield Township, on the Wetmore place, it is 5 feet thick (location $1^{9}$ ), nearly all

\footnotetext{
${ }^{1}$ White, I. C., Pennsylvania Second Geol. Survey Rept. Q, p. 238, 1878.

2 Idem, p. 260.

${ }^{3}$ Idem, pp. 50, 202.

${ }^{4}$ Idem, pp. 36, 213.

${ }^{5}$ Idem, p. 215.

${ }^{\circ}$ Idem, p. 200.

${ }^{7}$ Idem, p. 186.

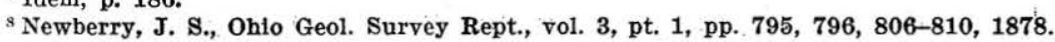

${ }^{9}$ For Ohio the locations are numbered by countles. (See Pl. V, p. 56.)
} 
cannel. On the Irving farm near by it comprises only 6 inches of cannel over 2 feet of bituminous coal. In Springfield and Beaver townships it has been opened at many points and shows "in some places, 6 feet thick of cannel, in others 3 feet thick, half cannel and half cubical coal, and in still others 3 feet thick with 6 inches of cannel on top. Where of cannel it contains on the average about 15 per cent of ash."

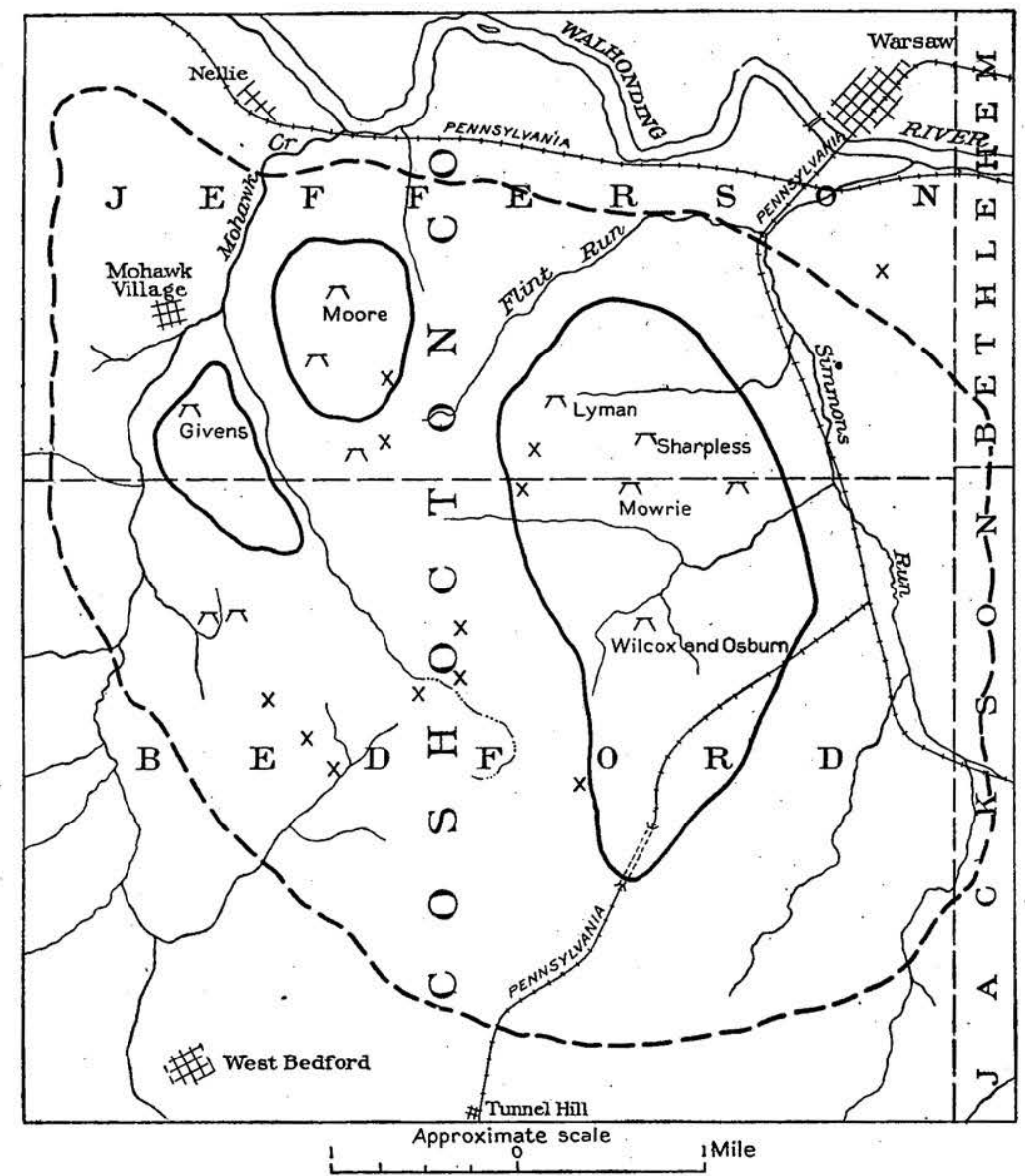

F'rgure 5.-Sketch map of cannel-coal basin in Jefferson and Bedford townships, Coshocton County, Ohio. (After Orton.)

The sections suggest that the cannel of workable thickness is in very small pockets. The Canfield cannel lies immediately below the "ferriferous or Vanport limestone."

\section{COSHOCTON COUNTY.}

In Bedford and Jefferson townships (location 4), Coshocton County, the coal known as Bedford cannel lies at the Upper Mercer 
horizon; total area is 12,000 to 13,000 acres, of which it is estimated that nearly 1,500 acres in three distinct basins will yield coal over 2 feet thick. In its best exposures the coal is 6 feet thick; and in several openings it comprises 5 feet or more of cannel overlain by

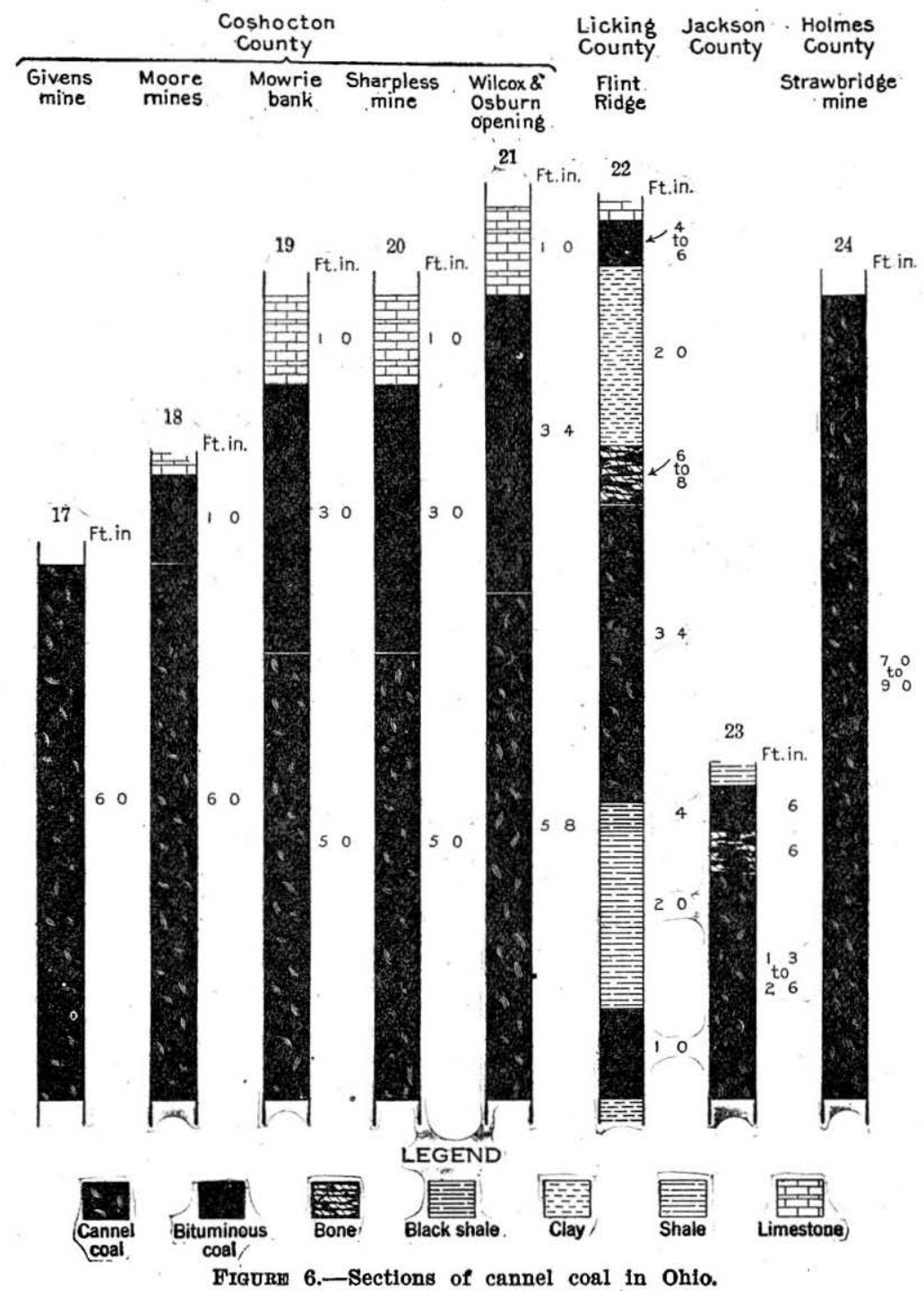

3 feet of bituminous coal. Nearer the boundaries the cannel thins and changes into an impure bone coal or a rich, block shale. The area of the field and the location of the sections is shown on figure 5, ${ }^{1}$

\footnotetext{
${ }^{1}$ Orton, Edward, Ohlo Geol. Survey Rept., vol. 5, Economic geology, p. 846 (map), 1884.
}

$87775^{\circ}-18-B$ Bull. $659-5$ 
The following notes are condensed from a description of the field by Orton ${ }^{1}$ published in 1884 . Coal over 2 feet thick is confined to three areas. In one, which lies south of Mohawk, the cannel as exposed at the Givens mine is 6 feet thick but has less luster and a less conchoidal fracture than that in the other areas. (See fig. 6, section 17.)

Another tract a mile east of Mohawk has been opened on the Moore Bros. places, where the cannel is 6 feet thick overlain by 1 foot of bituminous coal. The coal mines without powder, in blocks large and durable enough to be used locally for horse blocks, stepping stones, and the like. East of the Moore mines the coal thins down, but east of Flint Run bottoms it thickens again. At the Mowrie and Lyman banks it is 5 feet thick. At the Mowrie bank it is unusually hard and firm and is exclusively close grained and curly; the joint structure is so little developed as to make the use of powder necessary in mining. At the Sharpless mine the coal is highly conchoidal. The analysis given on page 26 represents the run of mine at this opening, including the whole bed. The coal is said to reach a thickness of 9 feet in the Wilcox \& Osburn opening. (See fig. 6, sections 17-21, and analyses 141, 142, p. 26.)

\section{LICKING COUNTY.}

The Flint Ridge cannel comes from Hopewell Township, in Licking County (location 5), where it has a thickness of 3 to 4 feet or less and is estimated to cover about 1,000 acres. This cannel has long been famous, probably in large part because before the discovery of oil in Pennsylvania it was distilled for oil in an extensive plant.

The coal is at the horizon of the Lower Mercer. Orton, ${ }^{2}$ writing in 1884, estimated that only about 10 acres of coal had been mined out, notwithstanding the fact that it has been mined for 50 years. In the mine the cannel bench averaged about $3 \frac{1}{2}$ feet in thickness, being nowhere less than 3 feet and rising about 4 feet only in the main swamps. At that time the coal was being mined by bearing in at the top and then shooting the coal up with powder. The miner could get only 2 tons a day by hard work, for which he received a dollar a ton. The coal sold at the mouth of the mine for $\$ 1.80$. If hauled to the railroad for shipping, the cost was increased by about a dollar. The cannel is described as curly and of excellent appearance, though high in ash. A shaft one-fourth of a mile east of the mine found 3 feet of good cannel. Two

\footnotetext{
${ }^{1}$ Orton, Edward, Ohio Geol. Survey Rept., vol. 5, Economic geology, pp. 845 et seq., 1884.

2 Idem, p. 908.
} 
miles to the east the cannel had a thickness of 2 feet 8 inches; 1 mile to the southeast 2 feet; and 2 miles to the southeast only 8 inches. (See fig. 6, section 22, and analyses 152-155, p. 26.)

JACKSON COUNTY.

In Milton Township, Jackson County (location 7), the Tionesta seam near the top of the Pottsville supplies some cannel of fair quality. (See analyses 149-151, p. 26.) The cannel portion ranges from 15 to 30 inches in thickness. It is overlain by, 6 inches of shaly cannel and that in turn by 6 inches of bituminous coal. (See fig. 6, section 23.) Its extent has not been determined. ${ }^{1}$

HOLMES COUNTY.

In Holmes County both the Upper and Lower Mercer coals carry. some cannel. ${ }^{2}$ In Killbuck Township (location 3) cannel from the Upper Mercer is locally 7 to 9 feet thick (fig. 6, section 24). That from the Lower Mercer ranges from 2 feet thick to 2 feet 6 inches in several places. (See analyses 143-148, p. 26.)

\section{SCIOTO COUंNTY.}

The Upper Mercer coal shows up to 20 inches of cannel at one or two points in Scioto County. The great coal of the Hocking Valley field (location 6) usually shows a few inches of bone, coal 10 to 18 inches from the top. Locally this changes to cannel and in a few places reaches a maximum thickness of 10 inches and is of excellent quality. At Pioneer station a mine, the Webster, has 16 to 20 inches of cannel coal. A little cannel has been shipped from the Cook mine. ${ }^{3}$

JEFFERSON COUNTY.

One of the most interesting occurrences of cannel in the State is at the Diamond mine (location 2), in Jefferson County. The coal here comprises 3 to 9 feet of bituminous coal, the greater thickness occuring in the "swamps," where lower benches come in. Beneath this, covering about an acre or two, is a bed of cannel 5 inches in maximum thickness. From this small bed Newberry has collected more than 50 species of fishes and reptiles, strong testimony to the water origin of cannel coal. ${ }^{4}$

${ }^{1}$ Orton, Edward, Ohio Geol. Survey Rept., vol. 5, Economic geology, p. 1032, 1884.

${ }^{2}$ Idem, p. 825.

${ }^{3}$ Idem, p. 1039.

${ }^{4}$ Idem, p. 212. 


\section{INDIANA.}

Thin beds of cannel coal are found in several of the counties. of this State, usually as benches on or in a bituminous coal bed. (See Pl. V, p. 56.)

\section{DAVIESS COUNTY.}

One basin of cannel coal of commercial thickness and extent oceurs at Cannelsburg, Daviess County (location $2^{1}$ ).

The bed ranges in thickness from 6 feet to 2 feet 6 inches, an aver-

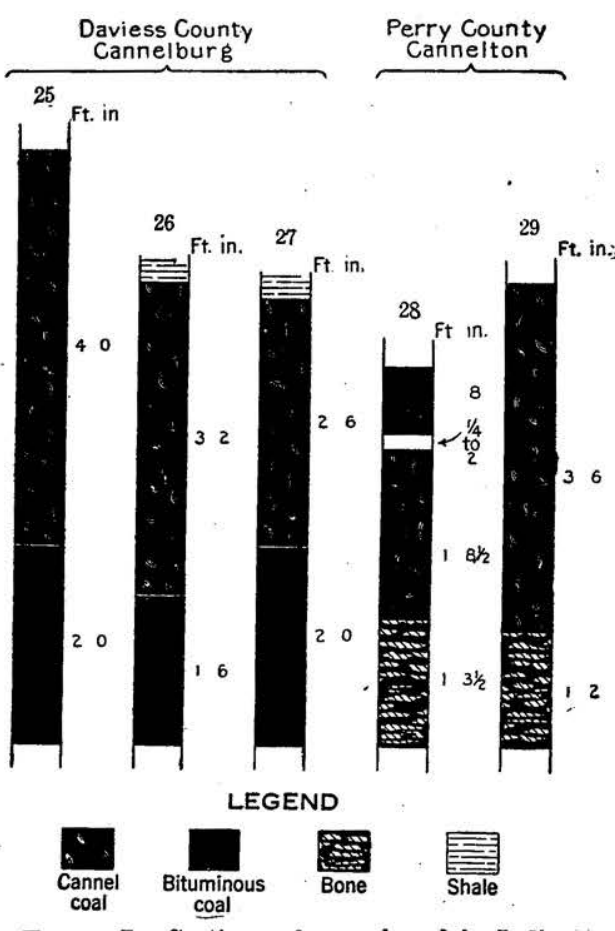
age being about 4 feet 8 inches, of which the top 3 feet 2 inches is cannel. (See fig. 7, sections 25-27.) The difference in thickness is mainly due to variation in the cannel, which lies in pockets in the bituminous coal, to which it adheres closely. Properly sampled analyses (19 and 20, p. 20) of this coal show 49.08 per cent of volatile matter, 26.35 per cent of fixed carbon, and 23.10 per cent of ash. Analyses of selected samples show 6 per cent or less of ash. Mining has shown this cannel coal to extend for at least a mile south of Cannelburg, and drillings indicate that the bed as a whole is of workable thickness over the Figure 7.-Sections of cannel coal in Indiana.

better part of 6.square miles, though whether the cannel has that extent is not known. An opening 2 miles south of Cannelburg showed only 6 inches of cannel. This coal is Coal III of the State series, being, like so many cannel-bearing coals, near the bottom of the coal series. ${ }^{2}$

PERRY COUNTY.

At Cannelton (location 1), in Perry County, on Ohio River, a coal has long been mined that might well be classed as a semicannel.

${ }^{1}$ Locality numbers for Indiana appear on Plate V, p. 56.

${ }^{2}$ Cox, E. T., Indiana Geol. Survey Third and Fourth Ann. Repts., pp. 25 et seg., 1872. Ashley, G. H., Indiana Dept. Geology and Nat. Res. Twenty-third Ann. Rept., pp. 90 et seq., 1899. 
It is dense and hard and breaks in any direction with conchoidal fracture. Analyses 22 and 23 (p. 20) show that it contains 42 per cent of volatile matter, 45 per cent of fixed carbon, and 6 per cent of ash. It lies in dish-shaped basins, thinning out entirely on the rise and thickening to 4 feet in the basins. ${ }^{1}$ (See fig. 7, sections 28-29.)

\section{PARKE COUNTY.}

Above the narrows of Sugar Creek, in the northeast corner of Parke County, cannel coal outcrops on what was the Newlin place, 2 miles north of Bethany (location 3). An analysis (21) is given on page 20. Two blocks of cannel of nearly half a ton each are reported as having been taken to Indianapolis from here, but when visited by the writer in 1897 only 6 inches of cannel coal could be found. ${ }^{2}$

\section{ILIINOIS.}

Cannel coal is found in Illinois in very small quantities only; as a rule it is found in lenses in association with bituminous coal. Two occurrences in northern Illinois have recently been described by Grout. ${ }^{3}$ At Colfax, McLean County, in the Colfax Cooperative Coal Co.'s mine, a 6-inch bed of cannel coal underlies the bituminous coal. On one side of the shaft lenses of cannel coal having a maximum thickness of 10 inches lie above the bituminous coal but have a horizontal extent of only about 100 feet. At La Salle cannel coal occurs in thin, irregular lenses on top of the coal in the Matheissen \& Hegeler mine in about a third of the territory opened. (See analyses 24,25 , p. 21.)

\section{MICHIGAN.}

Lane ${ }^{4}$ has reported of the Michigan coals that they "seem to lean generally toward cannel coal." It is a common condition in Michigan to find 3 to 8 inches of bone coal, cannel coal, or slaty coal above the main bed. On Rifle River, sec. 3, T. 19 N., R. 4 E., are 10 feet of black shale and cannel coal. The analysis shows 35 per cent of volatile matter, 45 per cent fixed carbon, and 11.8 per cent of ash. The thickness of the "cannel" is not stated. ${ }^{5}$ Cannel coal occurs on top of the Saginaw bed at St. Charles and elsewhere.

\footnotetext{
${ }^{1}$ Cox, E. T., Indiana Geol. Survey Third and Fourth Ann. Repts., pp. 95 et seq., 1872. Ashley, G. H., The coal deposits of Indiana : Indiana Dept. Geology and Nat. Res. Twentythird Ann. Rept., pp. 1256 et seq., 1899.

${ }^{2}$ Idem, p. 320.

${ }^{3}$ Grout, F. F., Cannel coal in northern Illinois: Illinois State Geol. Survey Bull. 4, p. 198, 1907.

"Lane, A. C., Coal of Michigan : Michigan Geol. Survey, vol. 8, pt. 2, p. 19, 1902.

5 Idem, pp. 91, 94, 105.
} 
WEST VIRGINIA.

\section{DISTRIBUTION OF THE COAL.}

The prominent part played by West Virginia (then Virginia) in the cannel-coal industry of early days has already been noted. During the last 30 years commercial cannel-coal mining has been confined to six areas. (See Pl. V, p. 56, and fig. 9, p. 72.) Cannel-coal mining continued at the Wacomah mines on Paint Creek until the late eighties, the mines being abandoned before 1890. In mining at this point, however, the Lackawanna Coal \& Lumber Co. still separates out the $15 \frac{1}{2}$-inch bench of cannel coal and sells it at double the price of the splint coal. ${ }^{1}$ Cannel-coal mining continued at Cannelton until after 1900. The cannel-coal basin on Falling Rock Creek was reopened by the Falling Rock Cannel Coal Co., in the early nineties and was operated until 1910. In recent years mining has been by the Wierwick Cannel Co. Later mining began again at Mill Creek, at first by the Mill Creek Cannel Coal Co., which in 1910 changed to the Villa Cannel Coal Co., and subsequently to the Mill Creek Cannel Mining Co. During the nineties some cannel-coal mining was done in Wayne County by the Wells Branch Co.

Recently, according to mine inspectors' reports, cannel-coal mining has been revived at Peytona by the Peytona Block Coal Co. The section, as measured at this mine and as reported in the recent detailed report on Boone County, however, shows no cannel coal but 2 feet 9 inches of splint coal underlying 10 inches of block coal, from which it is separated by a 2-inch parting. ${ }^{2}$ It is possible, however, that benches of cannel coal are separated out and marketed. The Sewall coal in the New River field very commonly carries a few inches of cannel coal or " cannelly" coal.

\section{PRESTON COUNTY.}

Cannel coal is reported to be carried by the Bakerstown coal at many points in the valley of Sandy Creek, in Preston County, probably at the horizon of the Lower Kittanning coal. ${ }^{3}$ The Bakerstown coal also carries a little cannel at the C. N. Matlick place, threetenths of a mile southwest of Marquess (section 30), where 15 inches of cannel overlies 9 inches of bituminous coal. ${ }^{4}$

\footnotetext{
1 Krebs, C. E., and Teets, D. D., Kanawha County : West Virginia Geol. Survey County Repts., p. 485, 1914.

${ }^{2}$ Krebs, C. E., and Teets, D. D., Boone County: West Virginia Geol. Survey County Repts., p. 262, 1915.

${ }^{8}$ White, I. C., The Appalachian coal field: West Virginia Geol. Survey, vol. 2, p. 297, 1903.

Hennen, R. J., and Reger, D. B., Preston County : West Virginia Geol. Survey County Repts., p. 139, 1914.
} 
BARBOUR COUNTY:

Three feet of cannel coal (fig. 8, section 31) is reported at the Lower Kittanning horizon at Moatsville, on Valley River (location $4^{1}$ ), just below the mouth of Teter Creek. ${ }^{2}$

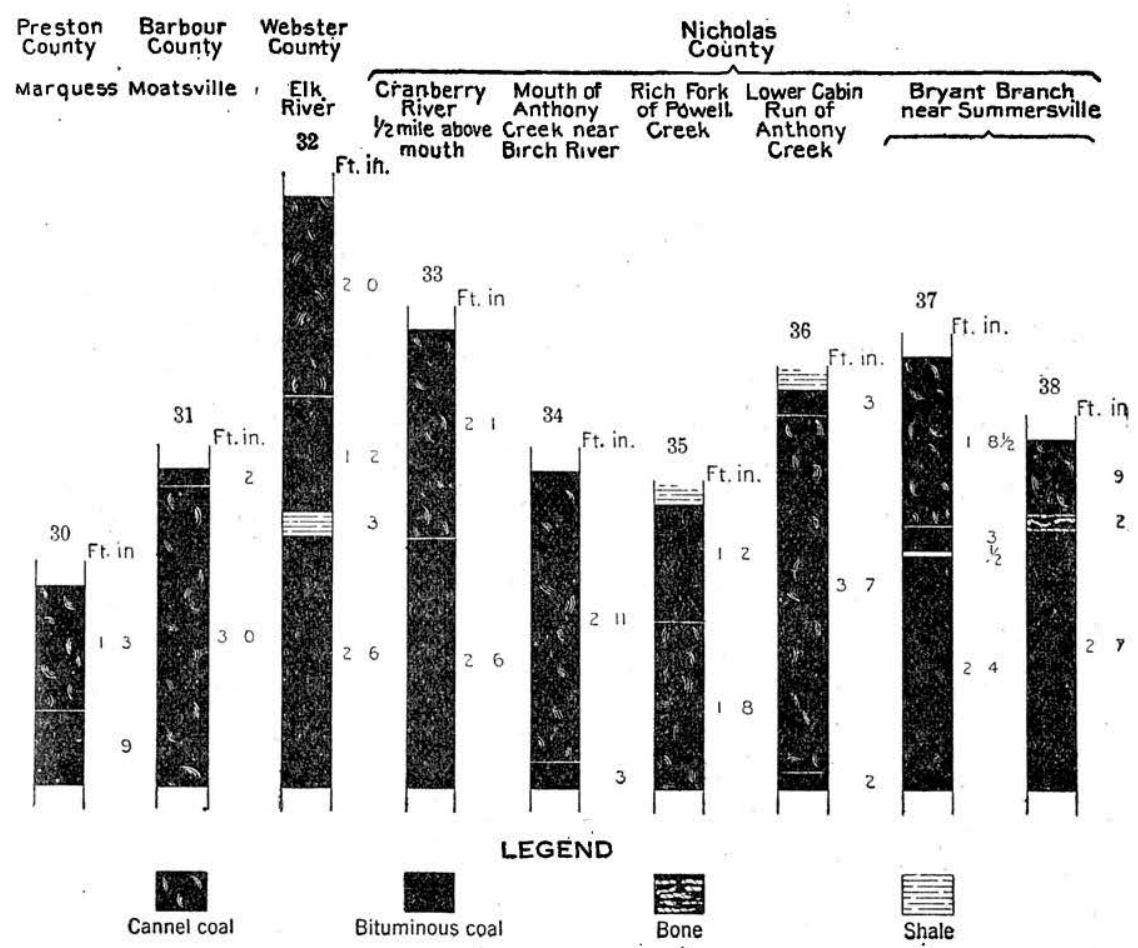

FrgURu 8.- Sections of cannel coal in Preston, Barbour, Webster, and Nicholas counties, W. Va.

\section{UPSHUR COUNTY.}

"Cannel slate" is reported from several places in Upshur County. Whether these beds will yield oil on distillation may be doubted on account of their easterly position in the coal field; they may, however, be noted for further investigation. The upper 2 feet of a coal bed at the crossing of the Coal \& Coke Railway and Buckannon River (location 4) is described as "cannel slate." 3 Still farther east (location 5) on the same railroad, $2 \frac{1}{2}$ miles from the crossing of Mill Fork River, ${ }^{4}$ is several feet of cannel shale.

\footnotetext{
${ }^{1}$ Location numbers for Preston, Barbour, and Braxton counties, w. Va., appear on Plate V (p. 56).

${ }^{2}$ White, I. C., The Appalachian coal field: West Virginia Geol. Survey, vol. 2, p. 297, 1903.

${ }^{3}$ White, I. C., Supplementary coal report: West. Virginia Geol. Survey, vol. 2(A), p. $486,1908$.

Idem, p. 518.
} 


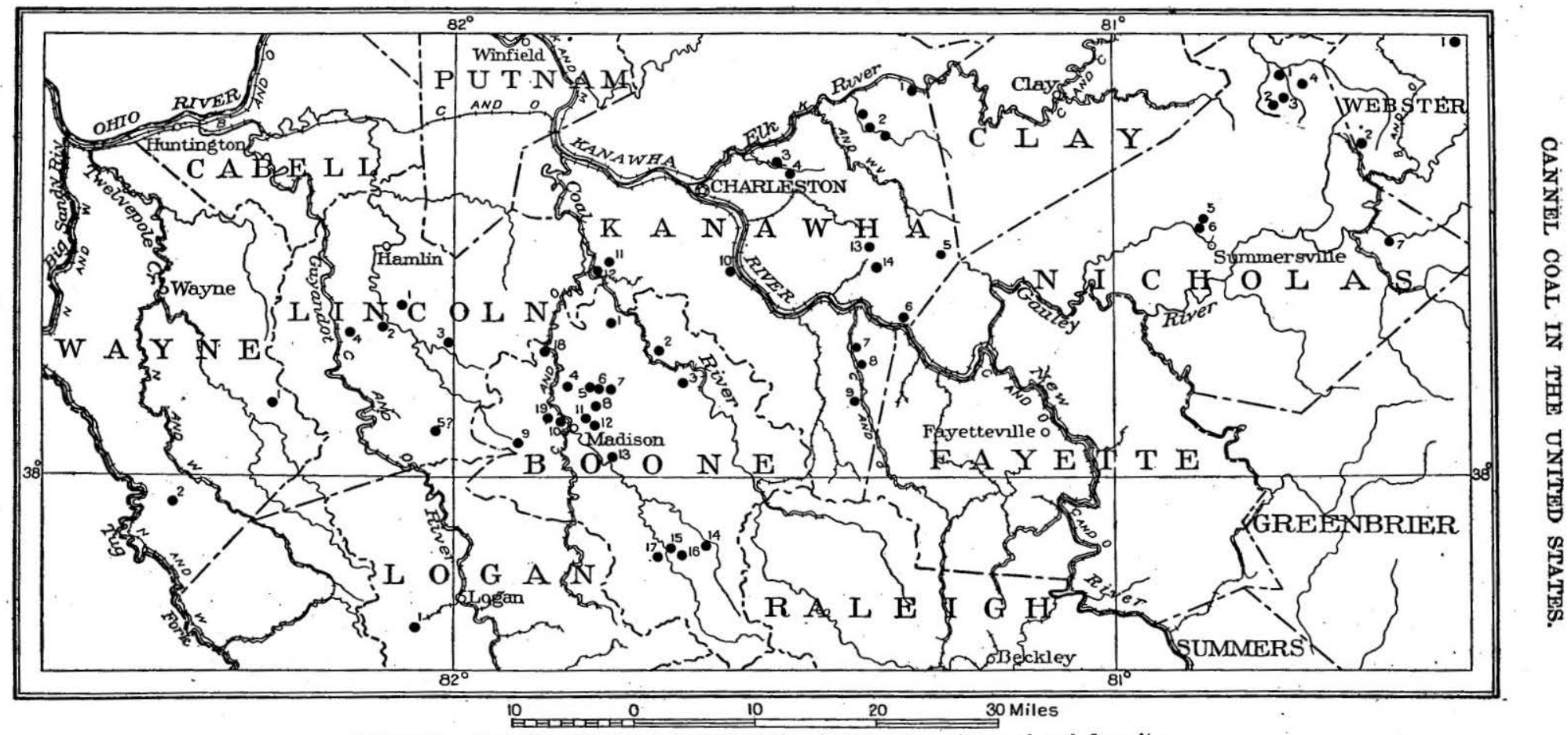

FIGURn 9.-Map of part of West Virginia showing position of cannel-coal deposits. 
BRAXTON COUNTY.

At the falls of the Little Kanawha, in Braxton County (location 3 ), are reported two beds of cannel shale, each 2 feet thick, separated by 5 feet of shale. Whether these are low enough in ash to be used for oil production is not known. 1 Twenty inches of "cannel slate" occurs at the top of the Stockton coal at the forks of Wolf Creek, 3 miles above the mouth, near the James Wyatt place. ${ }^{2}$

\section{WEBSTER COUNTY.}

Two feet of impure cannel coal capping a thick bed of bituminous coal (fig. 8, section 32) is found in Webster County (see fig. 9) at the head of Coal Spring Hollow (location $1^{s}$ ), from which a small branch flows to Elk River one-fourth of a mile above the mouth of Big Run, 6 miles below Webster Springs. ${ }^{4}$ A very similar section of cannel is found at the head of Stroud Creek (location 2), 5 miles north of Camden, on Gauley River, and has been observed on Laurel Creek and Elk River. ${ }^{5}$ Fourteen inches of shaly cannel occurs in the Eagle coal on Grassy Run, a branch of the right fork of Holly River. $^{6}$

\section{NICHOLAS COUNTY.}

Two feet of cannel coal over 30 inches of bituminous coal (fig. 8, section 33) occurs on the south side of Cranberry River $1 \frac{1}{2}$ miles above the mouth (location 7). The top of the coal grades into the black shale of the roof.

An extensive pocket of. cannel appears to lie south of Birch River between Powell Creek and Poplar Creek. At the mouth of Anthony Creek, $1 \frac{1}{2}$ miles above Birch River post office and 400 feet above the valley (location 1), on the Scott place, is a 3-foot bed of cannel (fig. 8, section 34). Farther south a bed of cannel coal, at possibly this same horizon, is reported as 4 feet thick (fig. 8, section 36 ) on lower Cabin Fork of Anthony Creek (location 3). It appears to run through the ridge to the west, showing 20 inches of cannel (fig. 8, section 35) on Rich Fork of Powell Creek (location 2). In

\footnotetext{
${ }^{1}$ White, I. C., The Appalachian coal fleld: West Virginia Geol. Survey, vol. 2, p. 449, 1903.

${ }^{2}$ White, I. C., Supplementary coal report: West Virginia Geol. Survey, vol. 2 (A), p. $483,1908$.

${ }^{3}$ Location numbers for Webster, Nicholas, Kanawha, Boone, Lincoln, Logan, and Wayne counties, W. Va., appear on fig. 9; a fresh set is begun for each cannel-bearing county.

${ }^{4}$ White, I. C., The Appalachian coal field: West Virginia Geol. Survey, vol. 2, p. 365, 1903.

5 Idem, p. 367.

${ }^{6}$ White, I. C., Supplementary coal report: West Virginia Geol. Survey, vol. 2 (A), p. 343,1908 .
} 
the ridge east of Anthony Creek the same bed is reported on the John Dodrill place on Poplar Creek as 3 feet thick with some cannel (location 4). Two miles southwest of Summersville on Brant Run is a bed of coal showing at one place (location 5) $20 \frac{1}{2}$ inches of shaly cannel above 30 inches of bituminous coal (fig. 8, section 37) and at another place, half a mile nearer Summersville (location 6), $9 \frac{1}{2}$ inches of cannel over 37 inches of bituminous coal (fig. 8, section 38).

\section{KANAWHA COUNTY.}

Queen Shoals.-A layer of cannel coal is found in rolls, and only in rolls, at the Queen Shoals Co.'s No. 1 mine (location 1): ${ }^{1}$ An analysis (183) is given on page 28.

Falling Rock.-Falling Rock (location 2) has long been the seat of cannel-coal mining (p. 51). Before the war a little distillery $1 \frac{1}{2}$ miles above the mouth of Falling Rock Creek was operated with cannel coal mined near by. Mining has gradually extended up the creek, and recently reached 6 miles or more from the mouth. Where mined in recent years the bed, known as the No. 5 block, consists of two benches of 8 and 20 inches, separated by 5 inches of shale. (Pl. VI, section 39.) The coal in the mine is reported to average from 2 to $2 \frac{1}{2}$ feet and to reach a maximum of 6 feet. $^{2}$

Villa -Cannel-coal mining has been in progress on Mill Creek since some time before the war. The Villa Coal Mining Co. is now operating at Villa (location 3), where the No. 5. block coal bed has a total thickness of 4 feet 7 inches, of which the top 2 feet 2 inches and the bottom 11 inches are glossy block cannel. The 1 foot 4 inches just above the shale partings is a bird's-eye cannel. (Pl. VI, section 40.) An analysis (184, p: 28) of the coal here shows 10 per cent of ash and 45 per cent of volatile matter. ${ }^{3}$ A section (Pl. VI, section 41) half a mile southeast of Villa (location 4) shows 3 feet of cannel separated from 2 feet of bituminous coal by 7 feet of sandstone. ${ }^{4}$

Pond Gap.-A mile southeast of Pond Gap, on Bell Creek (location 5), is a 2-foot bed of cannel (Pl. VI, section 42) on the G. W. Ramsay place. Ten feet lower is a 4 -foot bed of bituminous coal.

Mammoth.-I. C. White ${ }^{5}$ measured a section of No. 5 block coal on the left fork of Kelly Creek above Mammoth (location 13) and

\footnotetext{
${ }^{1}$ Krebs, C. E., and Teets, D. D., Kanawha County : West Virginia Geol. Survey County Repts., p. 439, 1914.

2 Idem, p. 441.

${ }^{3}$ Idem, p. 428.

* Idem, p. 189. See also White, I. C., Supplementary coal report: West Virginia Geol. Survey, vol. 2 (A), p. 547, 1908.

${ }^{5}$ White, I. C., op. cit., p. 543.
} 
Kanawha County

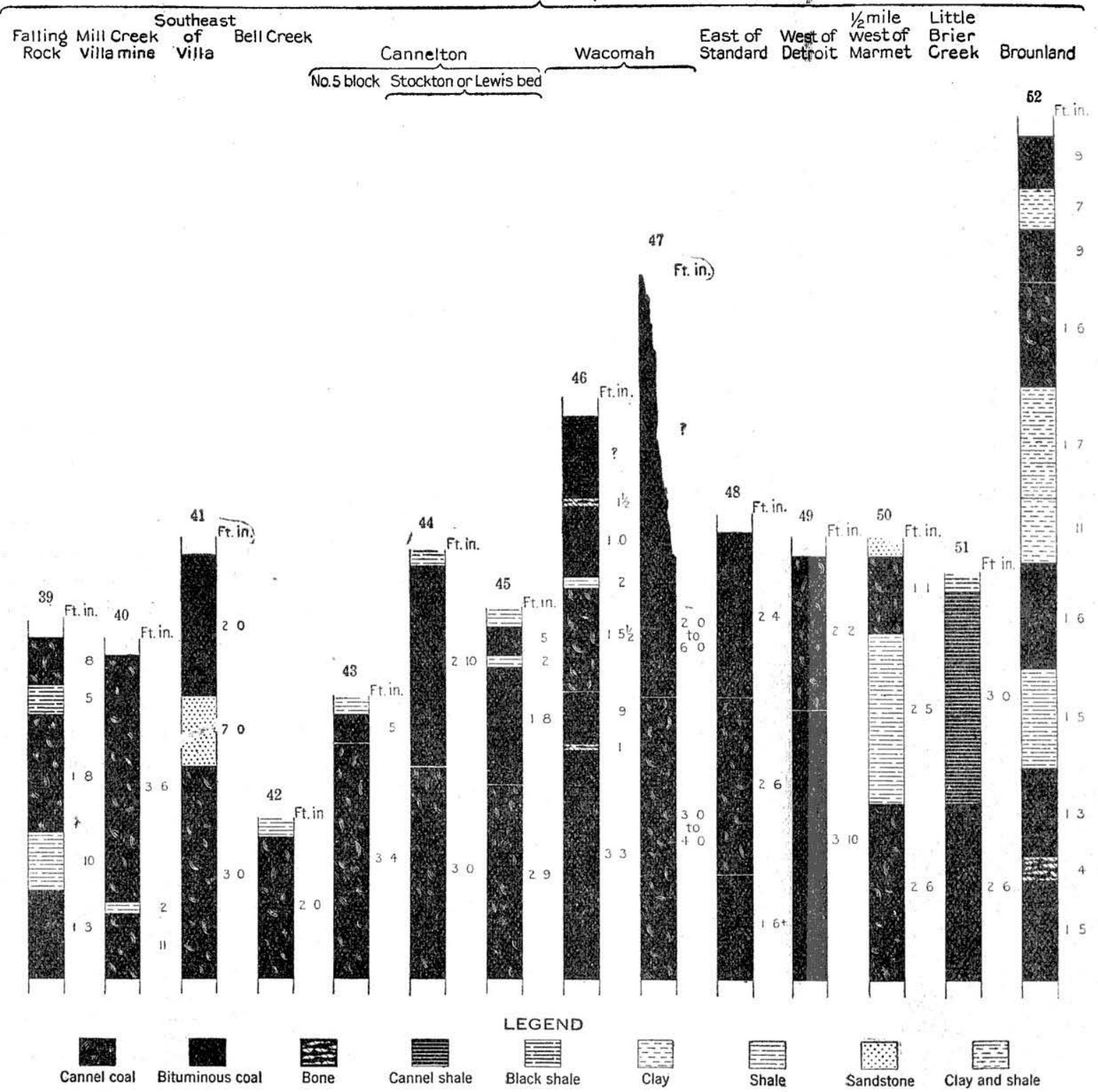

8ECTIONS OF CANNEL COAL IN KANAWHA COUNTY, W. VA. 

found it to contain 18 inches of shaly cannel over 6 inches of cannel shale below 39 inches of bituminous coal. A little south of this, about 2 miles above the mouth of Fivemile Branch of Kelly Creek (location 14), a bed containing 22 inches of fair cannel coal and 23 inches of bituminous coal has been opened. ${ }^{1}$

Cannelton.-Mining by the Cannelton Coal Co. was begun at an early date at Cannelton (location 6) and was continued until comparatively recent days. Cannel coal occurs here in both the No. 5 block (Pl. VI, section 43), which comes just above the Kanawha black flint (the key rock of the district), and in the Stockton coal (Pl. VI, sections 44, 45), which comes just below the black flint. According to sections by Edwards ${ }^{2}$ the higher bed contained 40 inches of cannel overlain by 5 inches of bituminous coal, and the lower bed contained 3 feet of cannel overlain by nearly 3 feet of bituminous coal. The top of the bed was only 10 inches below the base of the black flint. (See analysis 184a, p. 28.)

Wacomah.-Wacomah (location 7) was long the site of extensive cannel-coal mining by the Kanawha Coal Co., and the cannel-coal bench is still being separated by the Lackawanna Coal \& Lumber Co. (p. 70), which is operating at this point on the Coalburg bed. (See Pl. VI, sections 46,47 .) An analysis $(185$, p. 28$)$ of the cannel shows 12 per cent of ash and 41 per cent of volatile matter. ${ }^{3}$

Standard.-At the opening of the Coalburg bed in the hill just east of Standard (location 8) there are 30 inches of cannel in a bed 6 feet 4 inches thick (Pl. VI, section 48$)^{4}$

Detroit.-Still farther up Paint Creek, in the ridge just west of Detroit station (location 9), the Coalberg bed (Pl. VI, section 49) carries 26 inches of cannel coal. ${ }^{4}$ The occurrence of cannel coal at this same horizon over so wide an area suggests the possibility that a large basin may be found on Paint Creek.

Marmet.-The Coalburg bed is also a cannel coal at the G. W. \& $\mathrm{N}$. A. Peel opening half a mile west of Marmet (location 10; Pl. VI, section 50), where it contains 3 feet 7 inches of coal separated into two benches by 2 feet 5 inches of shale. ${ }^{5}$

Lens Creek.-According to Lyman ${ }^{6}$ several of the beds on Lens Creek (locations 13 and 14) carry cannel. The so-called "slate vein" carries 14 inches of cannel in a 3 foot 5 inch bed in Church Hollow, south of the mouth of the creek. The "Factory cannel-

${ }^{1}$ White, I. C., op. cit., p. 544.

2 Edwards, W. S., Coals and cokes of West Virginia, pp. 48, 49, 1892.

s Krebs, C. E., and Teets, D. D., Kanawha County: West Virginia Geol. Survey County Repts., p. 485, 1914.

${ }^{4}$ Idem, p. 236.

Idem, p. 476.

${ }^{6}$ Lyman, B. S., Some coal-measure sections near Peytona, W. Va.: Am. Philos. Soc. Proc., vol, 33, pp. 282-309, maps, 1894. 
coal bed" is the one formerly worked at the old oil factory on Left Fork, where the section showed 2 feet 5 inches of cannel (only 1 foot 6 inches of which was good coal), overlain by $9 \frac{1}{2}$ inches of black clay and by 6 inches of bituminous coal. The same bed was opened again beside Nuby's house on Left Fork, where it showed 3 inches

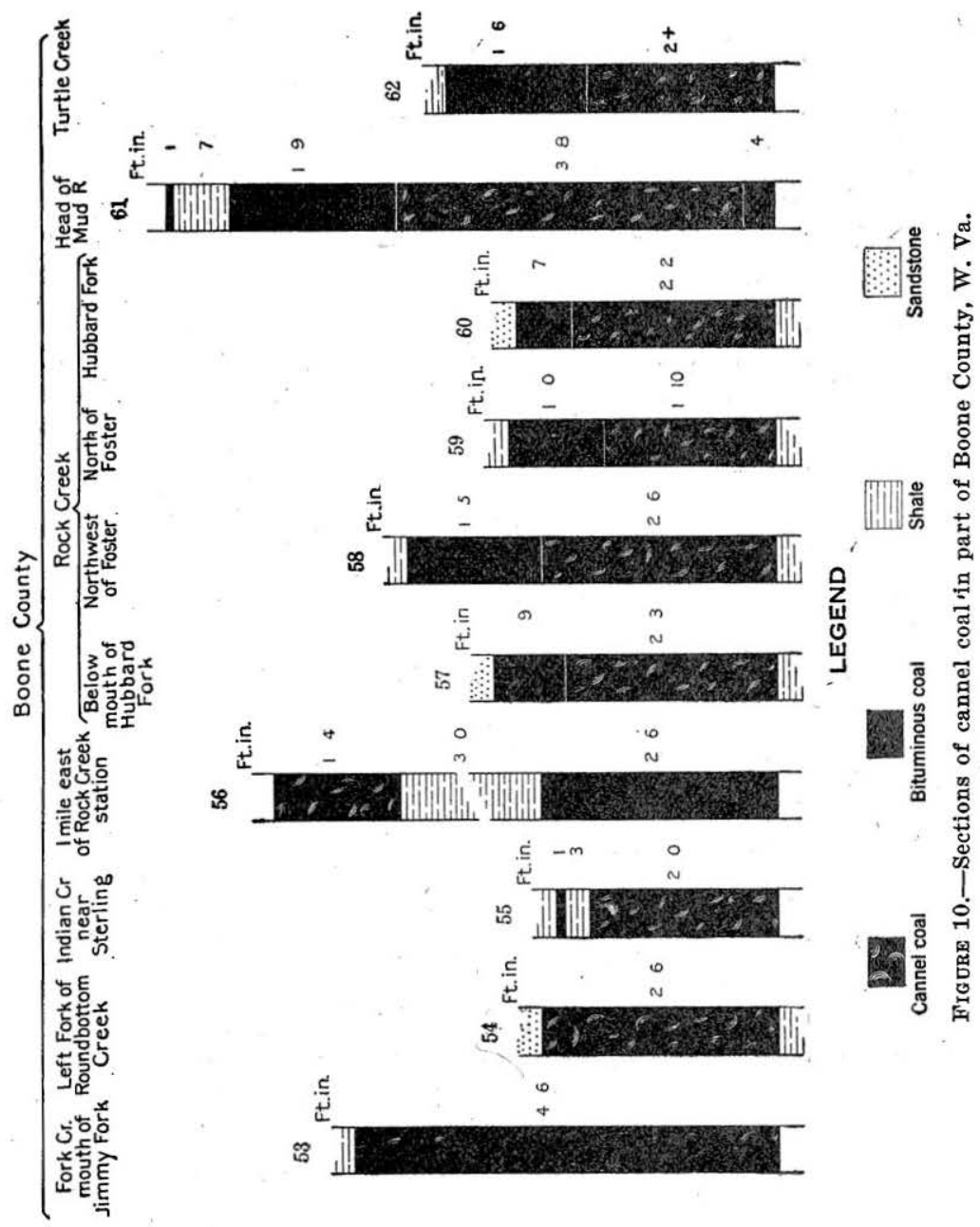

of poor cannel. Other sections of this coal bed gave only a few inches of cannel, the rest being good bituminous coal. Another bed, probably corresponding to the upper cannel at Peytona, is described as "a laminated cannel coal with thin seams of bituminous coal"; though having the analysis of a bituminous coal it mines out in large blocks like a cannel and is said to burn like a cannel. 
Brounland.-At the Courtney \& Brown opening near Brounland (locations 11 and 12), the Stockton-Lewiston bed has a thickness (Pl. VI, section 52) of 12 feet of coal with thin partings and carries 19 inches of impure cannel. ${ }^{1}$ At the Burrville Keefer place, on Little "Barrier" (Brier?)' Creek (Pl. VI, section 51), 3 feet of high-ash cannel (analysis 186, p. 28) overlies 30 inches of bituminous coal. ${ }^{2}$ An old opening 60 feet above the No. 5 block coal shows cannel coal.

\section{BOONE COUNTY.}

The cannel-coal industry was extensively developed in Boone County in early days (p. 51). The center of the development was at Peytona, two of the mines being at that point, though a recent detailed report on this county ${ }^{3}$ makes no mention of any cannel coal in the immediate area. A number of coal companies have been organized in this county for mining cannel coal.

Fork Creek.-A number of prospect openings have been made by the Fork Creek Coal Co. on. Fork Creek (location 1), where the No. 5 block bed ranges from less than 2 to more than 6 feet. In one of these openings the bed is cannel, having a thickness of $4 \frac{1}{2}$ feet (fig. 10, section 53). This opening is opposite the mouth of Jimmy Fork, 3.8 miles south of Brounland. ${ }^{4}$

Roundbottom.-A number of openings on the Henshaw coal were recently made by the Boone \& Kanawha Land \& Mining Co. on Roundbottom (location 2) and adjoining creeks. One of these, on the left fork of Roundbottom, shows (fig. 10, section 54) 30 inches of cannel coal. ${ }^{5}$

Sterling.-An opening by the Hickory Ash Coal Co. (fig. 10, section 55) on Indian Creek near Sterling (location 3) has developed 2 feet of cannel coal. ${ }^{6}$

Peytona.-Information as to the old cannel-coal mines about Peytona was obtained from Lyman's report. ${ }^{7}$ There were in this region two principal cannel-bearing beds known as the main cannel and the upper cannel. The upper bed measured 21 to 31 inches of smooth cannel at the Peytona mines. On Abshire Branch of Indian Creek, half a mile southeast of the Peytona mines, it carried 23 inches of cannel. Two hundred yards up the same branch in another

\footnotetext{
1 Krebs, C. E., and Teets, D. D., Kanawhia County : West Virginia Geol. Survey County Repts., p. 456, 1914.

2 Idem, p. 421.

${ }^{3}$ Krebs, C. E., and Teets, D. D., Boone County: West Virginia Geol. Survey County Repts., 1915.

4 Idem, p. 212.

5 Idem, p. $\mathbf{3 4 0 .}$

'Idem, p. 435.

${ }^{7}$ Lyman, B. S., Some coal-measure sections near Peytona, W. Va.: Am. Philos: Soc. Proc., vol. 33, pp. 282-309, 1894.
} 
opening it showed only 15 inches of cannel. Back of John McCarty's house on Droddys Creek, in an opening made in June, 1872, it contained 383 inches of cannel. Above the blacksmith shop on the same creek it showed only $10 \frac{1}{2}$ inches of coal, nearly all bituminous.

The main cannel bed, which was worked from about 1852, carried 20 to 41 inches of cannel, and as much as $17 \frac{1}{2}$ inches in places at the bottom was curly, underlain here and there by bituminous coal with a maximum thickness of 8 inches. An opening on the river front three-fourths of a mile northeast of the mines showed only a few inches of cannel. In the Abshire Hollow, half a mile southeast of the mines, the bed comprises two benches of cannel, 3 inches and 10 inches thick, separated by 11 inches of bituminous coal. Tests of the Peytona cannel by the Manhhattan Gaslight Co. of New York in 1869 gave a standard yield of 10,000 feet of 41-candlepower gas per long ton of coal, with a maximum yield of 13,200 cubic feet. The coal contained 49 per cent of volatile matter, 41 per cent of fixed carbon, and 13 per cent of ash.

Rock Creek.-A mile east of Rock Creek station (location 4) on Rock Creek, on the Samuel Cabell place, 16 inches of cannel coal associated with 30 inches of splint coal (fig. 10, section 56) is found. This bed appears to be part of an extensive basin of cannel that ${ }^{-} \mathrm{ex}-$ tends up Rock Creek above Foster and southward through the ridge toward Madison. ${ }^{1}$ On the Jackson Darlow place on the north side of Rock Creek below the mouth of Hubbard Fork (location 5) the cannel is reported to be 2 feet 3 inches to 3 feet 8 inches thick, overlain with 9 inches of bituminous coal (fig. 10, section 57). ${ }^{2}$ On the Samuel Carpenter place, northwest of Foster (location 6) this same coal, the Alma (fig. 10, section 58), carries 30 inches of cannel under 17 inches of splint coal. ${ }^{3}$ Just north of Foster, on the William Holstein place (location 7), the cannel bed is 22 inches thick (fig. 70, section 59) and overlies 12 inches of splint coal. ${ }^{3}$ On the J. A. Catley place (location 8), on the east side of Hubbard Fork of Rock Creek (fig. 10, section 60), the cannel is 22 inches thick and the splint 7 inches.

Madison.-Northeast of Madison (location 11) the Rock Creek cannel bed is 18 inches thick and the splint the same, separated by 1 foot of shale. ${ }^{4}$.

Mud River.-At the Floyd Nelson mine, at the head of Mud River, 2 miles southwest of Turtle Creek (location 9), there is a fine showing of cannel coal. (See fig. 10, section 61.) Two analyses (177,

\footnotetext{
${ }^{1}$ Krebs, C. E., and Teets, D. D., Boone County: West Virginia Geol. Survey County Repts., p. 322, 1915.

${ }^{2}$ Idem, p. 405 . White, I. C., Supplementary coal report: West Virginia Geol. Survey, vol. $2(\mathrm{~A})$, p. $598,1908$.

${ }^{3}$ Krebs, C. E., and Teets, D. D., op. cit., p. 405.

Idem., p. 406.
} 
178$, p. 27$)^{1}$ are so different as to suggest that one or the other sample was mixed with some other coal.

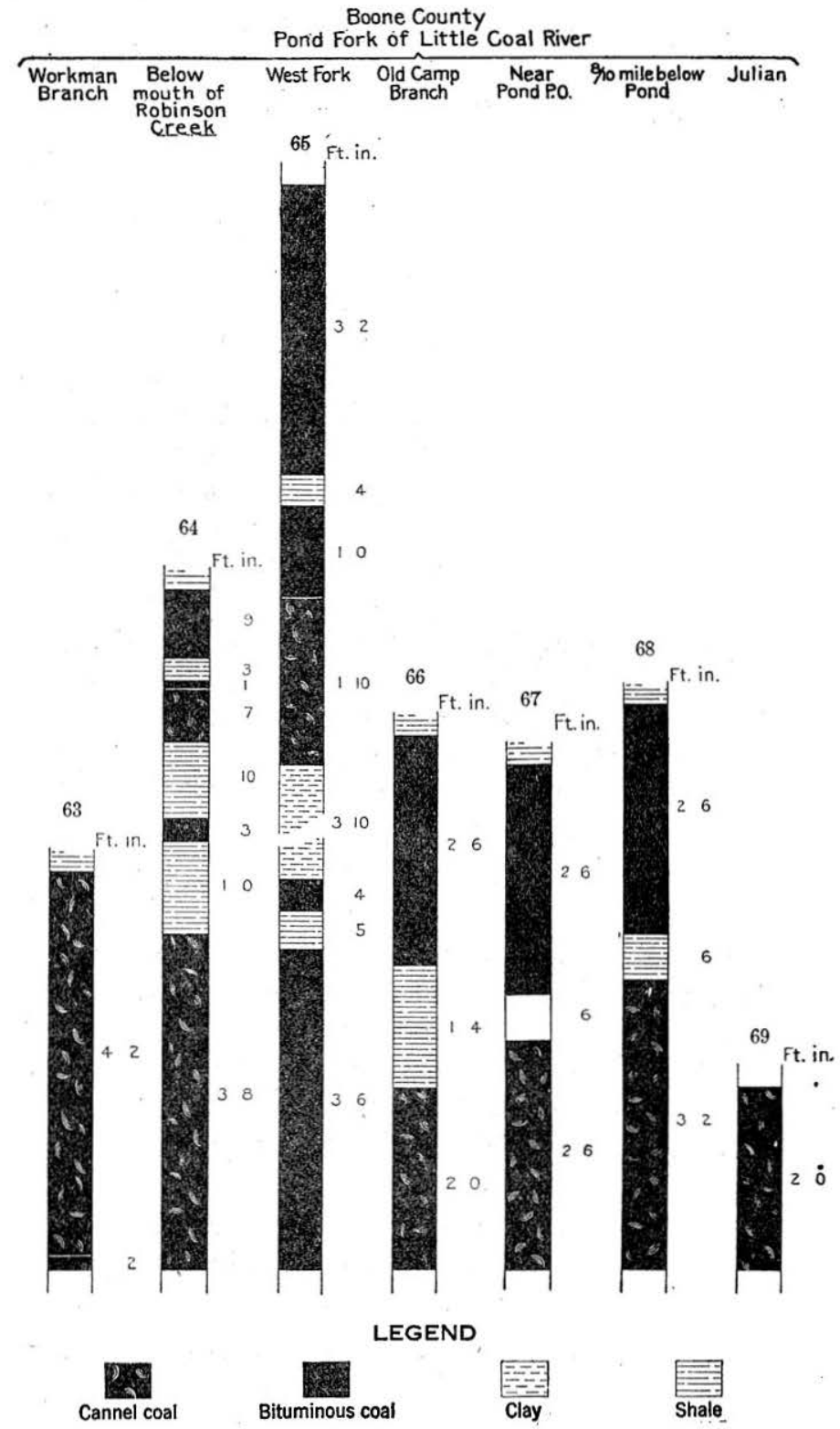

Frgure 11.-Sections of cannel coal on Pond Fork of Little Coal River, Boone County, W. Va.

Turtle Creek.-The Alma coal carries cannel on either side of Turtle Creek at the J. C. Ballard openings. On the south side, 
four-fifths of a mile southwest of Danville (location 10), 2 feet of cannel occurs (fig. 10, section 62), and on the north side of the creek on the same land (location 19) 15 inches of cannel was seen. The floor, however, was not reached in either section. ${ }^{1}$

Workman Branch. - Cannel coal has been noted 3 miles east of Madison on Workman Branch of Pond Fork (location 12), at the Bedford et al. opening (fig. 11, section 63). This is the Hernshaw coal and carries 50 inches of cannel. An analysis (180, p. 27) shows 12 per cent of ash and 51 per cent of volatile matter. This bed has not been opened at other points in this area, so its extent is not known. The coal was at one time hauled by wagon to Madison and there loaded on the cars for shipment. ${ }^{2}$

Pond Fork below Robinson.-About 5 miles above Madison on Pond Fork, half a mile below the mouth of Robinson Creek, on the W. P. Crafts place (location 13), there is a good cannel coal, 3 feet to 3 feet 8 inches thick (fig. 11, section 64). It appears to be the Williamson coal and it has long been mined for local use. An analysis (181, p. 27) shows about 12 per cent of ash and 47 per cent of volatile matter. ${ }^{3}$

West Fork.-On the west side of West Fork of Pond Fork at the mouth of James Creek, half a mile south of Chap post office (location 14), 22 inches of cannel (fig. 11, section 65) is found in the Winifrede coal on the land of E. J. Berwynd. ${ }^{4}$

Old Camp Branch.-The same bed shows 2 feet of cannel associated with 30 inches of bituminous coal (fig. 11, section 66) on the Wharton estate on Old Camp Branch (location 15), half a mile above the mouth. ${ }^{5}$

Pond post office.-On lands of the Wharton estate (location 16) just east of Pond ${ }^{6}$ post office the cannel thickens to 30 inches (fig. 11, section 67). This bench of cannel is over 3 feet thick (fig. 11, section 68) on the east side of a small branch of Pond Fork (location 17), half a mile above the mouth of Old Camp Branch and nearly a mile northwest of Pond. 4 (See section 68.) An analysis (182) is given on page 27 .

Julian.-Two feet of cannel coal (fig. 11, section 69) are reported at Julian on Little Coal River just south of the county line (location 18$).^{7}$

\footnotetext{
${ }^{1}$ Krebs, C. E., and Teets, D. D., Boone County: West Virginia Geol. Survey County Repts., p. 407, 1915.

${ }^{2}$ Idem, pp. 341-342.

${ }^{3}$ Idem, p. 374.

4 Idem, p. 309.

E Idem, p. 304.

Idem, p. 305.

${ }^{7}$ Krebs, C. E., and Teets, D. D., Cabell, Wayne, and Lincoln counties: West Virginia Geol. Survey County Repts., p. 146, 1913.
} 
LINCOLN COUNTY.

Laurel Fork of Mud River.-The No. 5 block $^{1}$ coal opened at the John Smith place on Laurel Fork of Mud River (location 1) near Jenks post office, where it contains 18 inches of semicannel coal overlying 28 inches of block coal (fig. 12, section 70).

Mud River.-The No. 5 block coal opened on the Hiram Seites place on Mud River $4 \frac{1}{4}$ miles from Midkiff (location 2), near Jenks; ${ }^{2}$

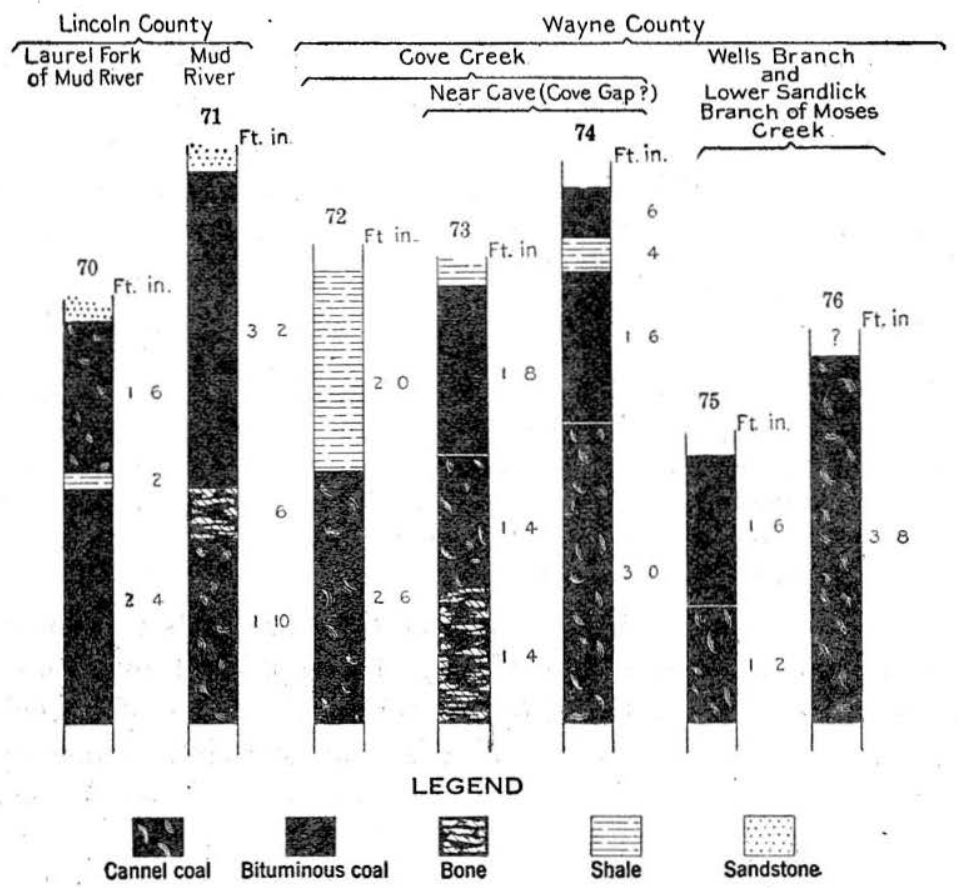

Figure 12.-Sections of cannel coal in Lincoln and Wayne counties, W. Va.

shows 22 inches of semicannel under 38 inches of block coal (fig. 11, section 71). An analysis (187b) is given on page 28.

Stinson Branch.-On Stinson Branch of the Left Mud, the lower Stockton coal carries 27 inches of cannel near Ed Simpson's (location 3$).^{3}$

Big Ugly.-Four feet of cannel coal is reported on the land of J. C. Chapman, in the hills adjoining Big Ugly Creek (location 5), in the southeastern part of this county. ${ }^{4}$

\footnotetext{
${ }^{1} \mathrm{Krebs}$, C. E., and Teets, D. D., Cabell, Wayne, and Lincoln counties : West Virginia Geol. Survey County Repts., p. 190, 1913.

${ }^{2}$ Idem, p. 191.

${ }^{3}$ White, I. C., Supplementary coal report: West Virginia Geol. Survey, vol. 2(A), p. $481,1908$.

4 Idem, p. 482.
}

$$
87775^{\circ}-18-\text { Bull. } 659-6
$$




\section{LOGAN COUNTY.}

Holden.-The Stockton bed near Holden, 4 miles above Logan (location 1), carries 3 feet of bony cannel in a total thickness of 12 feet 6 inches. Immediately above the cannel is 10 inches of bituminous coal and just below it is 2 feet of shale, underlain by 27 inches of coal. ${ }^{1}$

\section{WAYNE COUNTY.}

Cove Creek-The No. 5 block coal contains 30 inches of cannel coal (fig. 12, section 72) at the Lucian Wylie opening on Cove Creek. ${ }^{2}$ I. C. White ${ }^{8}$ describes a section (fig. 12 , section 73 ) near Cave (Cove Gap) post office in which the cannel portion of the bed is 16 inches thick and bony. Across the stream, however, this changes to 3 feet of good cannel (fig. 12, section 74).

From this point a narrow belt of cannel extends in a western direction nearly across Wayne County, being found on all of the main branches of Twelvepole. It is possibly identical with the Moses Fork cannel of Kentucky [West Virginia]. The belt varies much in width, but it is frequently 2 to 3 miles wide. While the cannel is sometimes absent, yet it is fairly persistent and seldom less than 20 inches in thickness, being generally of good quality, comparing favorably with the cannel from the Stockton coal horizon opposite Montgomery on the Great Kanawha.

The recent detailed report on Wayne County ${ }^{4}$ fails to mention or to give sections of such a belt of cannel except on Lower Sandlick Branch of Moses Creek (location 2), where 14 inches of cannel was measured. The cannel at this point was at one time mined by the Wells Branch Coal Co., the mine being located at Wells Branch but extending through the ridge to Moses Branch. Later the mine was sold to the Bradley Cannel Coal Co., which continued its development. The Bradley Cannel Coal Co. also opened another mine on the Stockton coal, which lies 100 feet lower and which at that point proved to be nearly all cannel (fig. 12, sections 75,76 ).

\section{KENTUCKY.}

PRODUCTION.

Kentucky is the premier cannel-coal State of the Union. It has not only been the principal source of cannel in the past but it probably still contains the largest deposits of unmined cannel in the United States except those in Webb County, Tex. (See Pl. VII.)

\footnotetext{
${ }^{1}$ White, I. C., op. cit., p. 475.

${ }^{2}$ Krebs, C. E., and Teets, D. D., Cabell, Wayne, and Lincoln counties : West Virginia Geol. Survey County Repts., p. 218, 1913.

${ }^{3}$ White, I. C., The Appalachian coal field: West Virginia Geol. Survey, vol. 2, p. 543, 1903.

4 Krebs, C. E., and Teets, D. D., op. cit., pp. 253-254.
} 


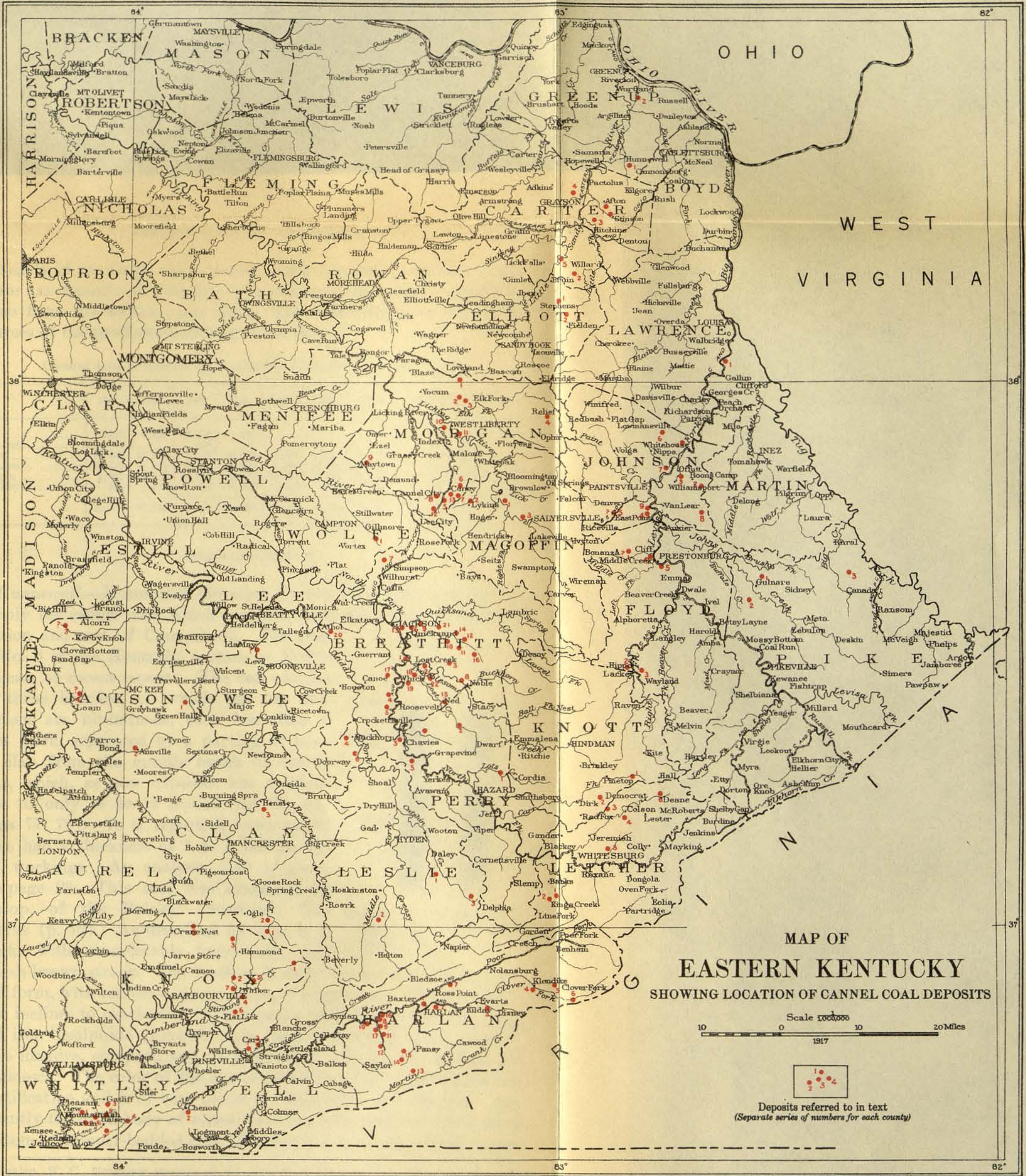

Base from U.S. Geological Survey

Coal data compiled by G. H. Ashley 

Nearly if not quite every county along the eastern border of the State has deposits of workable size, and some high-grade cannel has come from the western coal field. The following table shows the sources of the production during recent years:

Cannel coal produced in Kentucky, 1901-1910, in short tons.

\begin{tabular}{|c|c|c|c|c|c|c|c|c|c|c|}
\hline & 1901 & 1902 & 1903 & 1904 & 1905 & 1906 & 1907 & 1908 & 1909 & 1910 \\
\hline \multirow{6}{*}{ 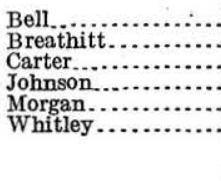 } & $\tau, 348$ & 6,293 & $\begin{array}{r}6,022 \\
648\end{array}$ & $\begin{array}{r}1,136 \\
255\end{array}$ & & & & & \multirow{5}{*}{$\begin{array}{r}830 \\
2,742 \\
7,941 \\
59,485\end{array}$} & $\begin{array}{r}1,298 \\
39\end{array}$ \\
\hline & ii, 203 & {$[11,3$} & 8,341 & 2,780 & 5,306 & 2,384 & $\dddot{2}, 440$ & & & \\
\hline & 14,153 & 15, & 5,662 & $\overrightarrow{7}, 500$ & 7,201 & 10 & 19,446 & & & 6,324 \\
\hline & 3,067 & 32, & 46,314 & 52,492 & 73,603 & 50,051 & 51,800 & ;..... & & 68,447 \\
\hline & 515 & & 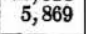 & 4,237 & 2,306 & 1,959 & 252 & & & \\
\hline & 36,287 & 67,056 & 72,856 & 68,400 & 88,416 & 64,971 & 73,938 & 70,413 & 70,998 & 76,108 \\
\hline
\end{tabular}

\section{GREENUP COUNTY.}

Hunnewell.-Hunnewell (location 1) has long been a source of supply for cannel coal, which is mined from the ridge south of the station and east of Cane Creek. The coal is No. 3 of the Kentucky section or Lower Stinson of recent reports. The bed consists of three benches, of which the top and bottom are bituminous, each less than a foot thick, separated by a parting of bone or clay from the middle bench of cannel coal, which, as now exposed, has a thickness of only 14 to 16 inches (fig. 13, sections 77,78$)$. It is reported, however, to have had a thickness of 3 to 4 feet in the old workings. An analysis (71) is given on page 23. This coal was examined by Hislop, of the Paisley (Scotland) Gas Works (p. 40). As described by him, it is black, with considerable luster and yel-

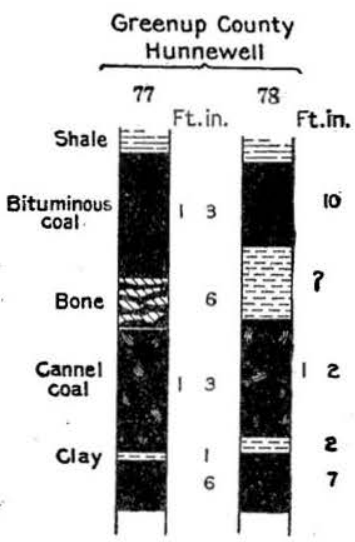

Figure 13.-Sections of cannel coal in Greenup County, Ky. lowish-brown streak. The fracture is slaty, coarse, and partly semiscaliform, with numerous impressions of stigmarias. The cross fracture inclines to conchoidal, with deposits of calcium carbonate, clay, and iron bisulphide (pyrite) under natural partings (joint planes). It is massive, compact, and very cohesive. On the fire it does not intumesce. The color of the ash is pale brown; it is well defined in stratification and is of very uniform composition and density. ${ }^{1}$ Apparently the main body of cannel here has been removed, but a good acreage of thinner-bedded coal, like that shown in the columnar sec-

${ }^{1}$ Phalen, W. C., Economic geology of the Kenova quadrangle, Ky., Ohio, and W. Va.: U. S. Geol. Survey Bull. 349, p. 90, 1908. 
tions, may still remain; or prospecting may reveal other minable bodies. ${ }^{1}$

Chinns Branch.-In the Kentucky Geological Survey report for 1858-59 an analysis of coal from Chinns Branch (location 2) is accompanied by the following description: ${ }^{2}$

Coal labeled " cannel coal sent by Col. L. G. Bradford, of Augusta; obtained from a bed about 4 feet 10 inches thick on the farm formerly. owned by Levin Shreve, of Louisville, known as Fulton Forge, 3 miles above Greenupsburg and 1 mile from Ohio River, Greenup County, Ky. In large blocks not soiling the fingers cleaving in regular layers with no fibrous coal between them; of a jet-black color. In small portion more slaty with pyritous impressions of vegetable remains. Over the spirit lamp it softened and agglutinated somewhat but did not swell much.

(See analyses 72-74, p. 23, and report of tests, p. 14.)

The development of this tract of cannel coal was begun by the Maysville Manufacturing \& Mining Co., in 1859, but the discovery of rock petroleum the same year broke up the enterprise. The cannel coal was described in a later report (with map) by Crandall, ${ }^{3}$ as follows:

The cannel coal of workable thickness appears to be limited in this region to an area oblong in outline, having its axis along the line from the old Fulton mines near the landing to a point on Indian Run, in the East Fork Valley. How far beyond Indian Run and how wide the area of cannel coal of workable thickness is has not been fully determined, but it may reasonably be estimated at from 1,500 to 2,000 acres. Several hundred acres of this area, belonging to the Fulton tract, have already been worked out, as also several narrow points in the valley of Chinns Branch, on the Caroline tract; but the great body of coal, covering a considerable portion of the latter tract, remains to be mined. The best information obtainable as to the thickness on the old Fulton tract gives it an average of about 3 feet. Further up, on Chinns Branch, the bed has reached a thickness of $4 \frac{1}{2}$ feet. On Indian Run it is about 2 feet but superior to the thicker part for gas making. Like all cannel coals it will probably be found variable in thickness and quality in the working of the bed. On Indian Run the bed is accompanied by common bituminous coal, 1 foot on top and 6 to 8 inches below, making the whole bed about the same in thickness as the average on Chinns Branch, where the whole thickness is cannel.

\section{CARTER COUNTY.}

Boghead.-The Boghead coal is found on Upper and Lower Stinson creeks (location 1), 2 to 3 miles east of Grayson, the county seat, between Boghead (Afton post office) and Stinson. The coal has, long been noted because of its extreme richness in oil, yielding under test 100 to 110 gallons of oil to the ton. ${ }^{4}$ The cannel occurs in two

\footnotetext{
${ }^{1}$ Crandall, A. R., Coals of the Licking Valley region: Kentucky Geol. Survey Bull, 10, p. $65,1910$.

${ }^{2}$ Owen, D. D., Kentucky Geol. Survey Fourth Rept., p. 171, 1861.

${ }^{3}$ Crandall, A. R., Report on the Chinns Branch cannel-coal district: Kentucky Geol. Survey Repts. on the eastern coal field, C, pp. 5-6 [293-294], 1884.

- Owen, D. D., op. cit., pp. 111-114.
} 
beds, Nos, 3 and 4 of the Kentucky section, or the Upper and Lower Stinson of recent reports. ${ }^{1}$ The upper of the two coals is generally workable in this region but is mainly a splint and bituminous coal.

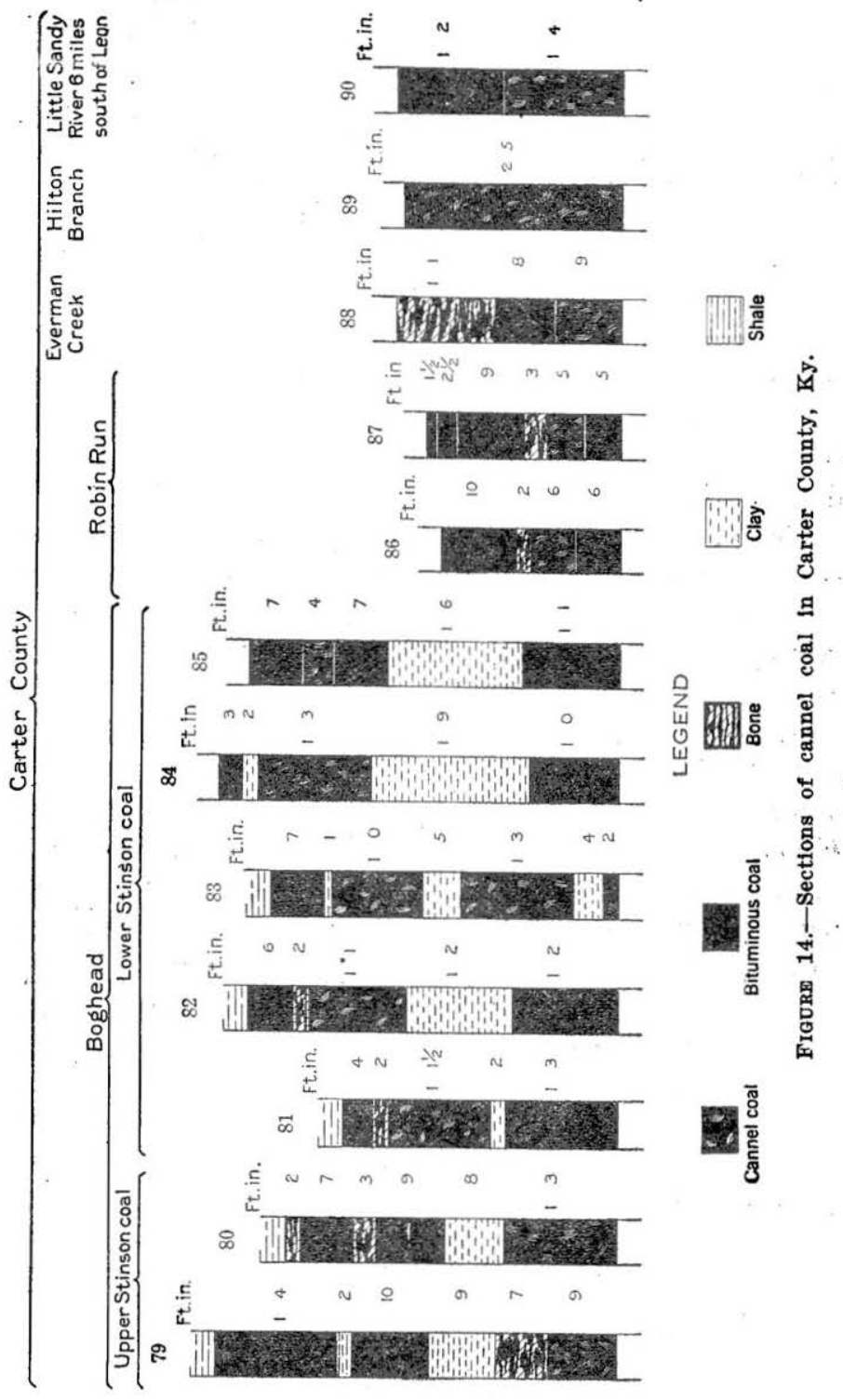

In the Boghead area it contains an important bench of cannel coal which has been worked on Lower Stinson Creek by the Kentucky Cannel Coal Co. (fig. 14, sections 79-85). The old Lexington and

${ }^{1}$ Phalen, W. C., Economic geology of the Kenova quadrangle, Ky., Ohio, and W. Va.: U. S. Geol. Survey Bull. 349, pp. 85-92, 1908. 
Carter Coal Mining Co. is said to have worked out a considerable territory southeast of the present workings.

The Lower Stinson coal, 30 feet below the Upper Stinson, is generally workable about Boghead. As at Hunnewell it is in three benches but is extremely variable, as is shown by the sections given. This coal is described by Hislop ${ }^{1}$ as-

black and possesses a yellowish-brown streak and high luster. The fracture is slaty, coarse, and dull with impressions of stigmaria, while in the cross fracture it is conchoidal, with cuttings of fire clay on the natural partings [joint planes presumably]. It is very compact and cohesive. On the fire it partially and slightly intumesces. The color of the ash is brown. It is well defined in stratification and is of very uniform density.

Where weathered this coal splits into very thin leaves, some of which, measured by the writer, averaged about $\frac{1}{250}$ of an inch in thickness. Analyses (62-64) are given on page 22.

The Boghead cannel has been studied microscopically by David White. ${ }^{2}$

Robin Run.-The Lower Stinson coal has been opened at many places in the hills about Robin Run (location 3), 2 miles southeast of Grayson, ${ }^{3}$ and at some of them cannel coal was found suggesting a possibly workable extension of the Boghead area (fig. 14, sections $86,87)$.

Everman Creek.-What is probably a lower coal, opened on Barrett and Everman creeks (location 4), contains some cannel (fig. 14, section 88 ) in two benches. ${ }^{4}$

Hilton Branch-On. Hilton Branch of Little Fork of Little Sandy River (location 2); a few miles southwest of Willard, the Upper Stinson or No. 4 coal is in part cannel (with a reported thickness of 3 feet), overlain by a foot of bituminous coal. It has been found on the Elijah Sturgill and William Corey places, on the latter of which the cannel part of the bed has a maximum thickness of 29 inches (fig. 14, section 89). The cannel coal was not seen north or south of Hilton Branch.

\section{Little Fork of Little Sandy River.-According to Hendrie 5 -}

One of the most valuable deposits in this county, however, is found 4 miles northeast of Willard Station $* * *$ and 6 miles southwest of Leon Station, * * * lying on the waters of the Little Fork of the Little Sandy River. The cannel blocks vary in thickness from 10 to 32 inches. An average section,

\footnotetext{
${ }^{1}$ Phalen, W. C., op. cit., pp. 89-90.

${ }^{2}$ White, Darid, and Thiessen, Reinhardt, The origin of coal: Bur. Mines Bull. 38, pp. 252-253, 1913. Owen, D. D., Kentucky Geol. Survey Fourth Rept., pp. 111, 114, 1861. Phalen, W. C., op. cit., pp. 85-92.

${ }^{3}$ Phalen, W. C., op. cit., pp. 87-89.

Idem, pp. 88-89.

.5 Hendrie, Charles, Some Kentucky cannels: Kentucky Inspector of Mines Tenth Ann. Rept., p. 146, 1894.
} 
taken from an average of 21 measurements, shows a bed section as follows: Bituminous coal, 1 foot 2 inches; cannel coal, 1 foot 4 inches. [See fig. 14, section 90.]

The quality of this coal is shown by the analysis (No. 67, p. 22).

ELLIOTT COUNTY.

Ison Creek.-In the area between the Little Sandy and Little Fork the No. 6 bed or Winslow coal carries some cannel. In the ridge between Ison and Creechs creeks (location 2) it has been opened at several places. On the Andrew Stevens land, on the Creechs Creek side, it shows 40 inches of cannel over 3 inches of splint coal. ${ }^{1}$ Similar showings occur on the Ison Creek side on the Thomas Caldwell and Isom Ison land. One section, measured by the writer, at the head of Ison Creek showed 32 inches of cannel. ${ }^{2}$ (See fig. 15, sections $91,92$.

Bruin Creek.-Two miles north of the last locality, on Greasy Run between Bruin Creek and the left fork of Brush Creek (location 1), the Winslow bed (fig. 15, section 93) shows 24 to 30 inches of cannel. ${ }^{3}$ The coal here appears to contain considerable ash.

Sarah.-At Sarah a 12-inch bench of cannel coal lies at drainage level, 8 inches below the top of a 28 -inch bed of bituminous coal. (See Pl. I, A.)

\section{LAWRENCE COUNTY.}

Torchlight.-In the Torchlight area (location 1) is the bed known as the "little cannel," the name being derived from a bed of cannel 3 to 6 inches thick in the middle of the coal. The "little cannel " has been opened near the head of Threemile Creek and at one time was mined and shipped over the Chatteroi Railroad. It is of interest because of this and of the further fact that specimens were sent to the World's Columbian Exposition, where an analysis (98, p. 24) was made. (See also analysis 99.) The bed has also been tested by Hislop, who reports "this is an excellent cannel coal." 4

JOHNSON COUNTY.

Whitehouse.-Cannel coal has long been mined at Whitehouse ${ }^{5}$ (location 1). The cannel bed is 18 to 20 inches thick and underlies 18 inches of bituminous coal (fig. 15, section 94). Analyses (89, 89 ) are given on page 23 .

\footnotetext{
1 Crandall, A. R., Coals of the Licking Valley region: Kentucky Geol. Survey Bull. 10, p. 74, 1910 .

2 Phalen, W. C., op. cit., pp. 102-103.

${ }^{3}$ Crandall, A. R., op. cit., p. 75.

4 Phalen, W. C., op. cit., p. 59.

- Crandall, A. R., Kentucky Geol. Survey Bull. 4, p. 28, 1905.
} 
Georges Creek.-Cannel coal on Georges Creek (location 6), John: son County, is referred to by Crandall. ${ }^{1}$

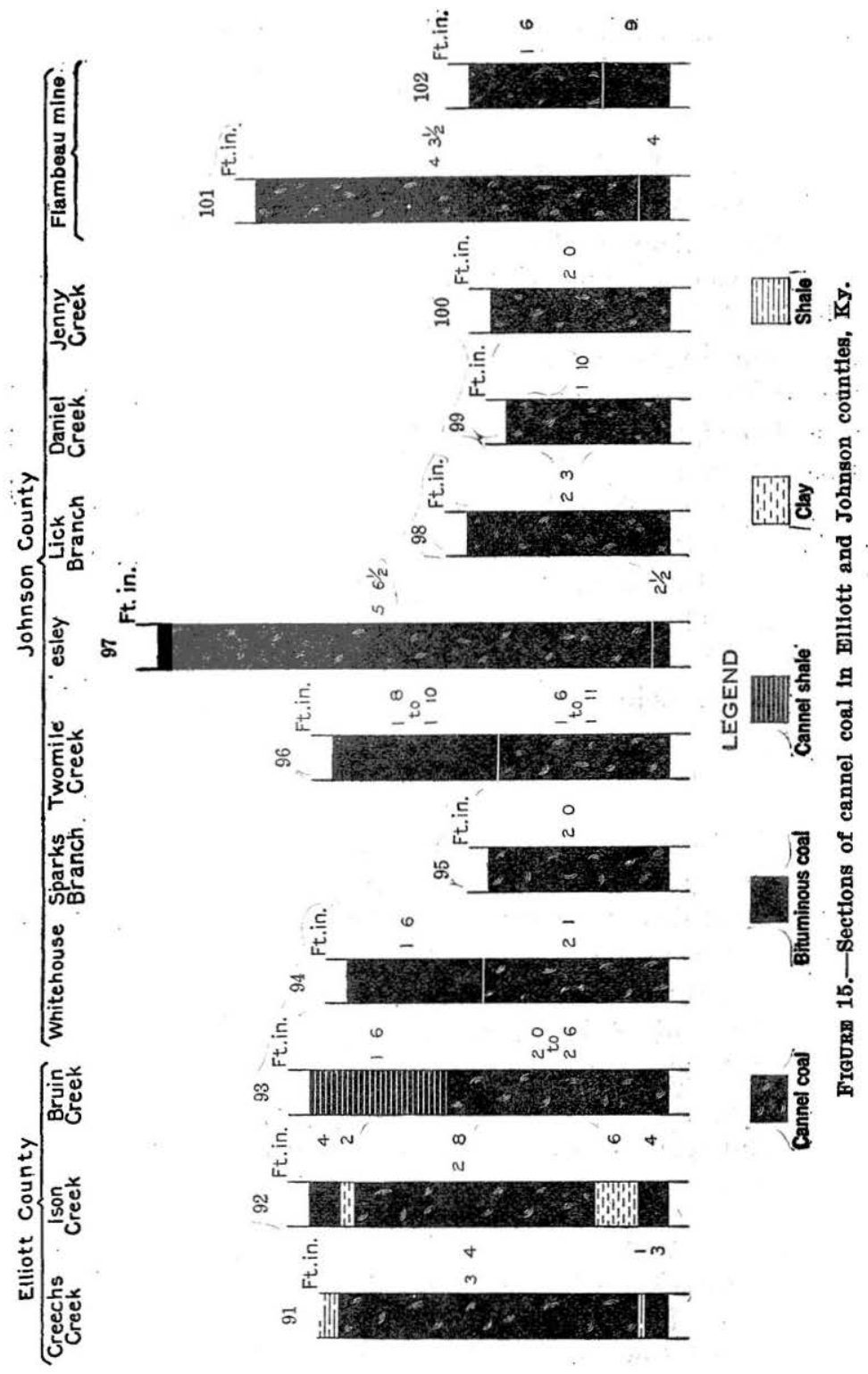

Sparks Branch.-On Sparks Branch (location 1) of Right Fork of Greasy Creek ${ }^{2}$ the Whitehouse coal shows 2 feet of slaty cannel (fig. 15, section 95 ).

1 Crandall, A. R., Preliminary report on the geology of Morgan; Johnson, Magoffin, and Floyd counties: Kentucky Geol. Survey, 2d ser., vol. 6, pt. 5, p. 15 [329], [1880].

2 Crandall, A. R., Kentucky Geol. Survey Bull. 4, p. 84, 1905. 
Twomile Creek.-Cannel coal has been mined $^{1}$ on Twomile Creek (location 3 ) by the Sandy River Coal Co. and carried by tramroad to the Chesapeake \& Ohio Railway at Ward. The bed shows 18 to 23 inches of good cannel (analysis 90, p. 23), overlain by 20 to 22 inches of bituminous coal (fig. 15, section 96).

Lesley (East Point post office).-The Whitehouse bed has been mined in a high ridge at Lesley (location 4). (See fig. 15, section 97.) This coal has been described by David White ${ }^{2}$ as follows:

At the mine of the East Kentucky Coal Co. at Lesley the coal measures 5 feet 9 inches at the point where the sample exhibited at the Jamestown Exposition was mined. The basal layer, about $2 \frac{1}{2}$ inches in thickness, is a very pure coal, partly bituminous and speckled, showing that the more typical cannel-forming conditions did not obtain until some time after the beginning of coal formation at this point. Above this basal bed the cannel continues to the top, save an interruption by 4 inches of stratified and somewhat laminated coal about $2 \frac{1}{2}$ feet above the base. The roof is a rather gritty gray shale, with water-worn stems and more or less comminuted, transported plant débris, all somewhat macerated.

The cannel is black, tough, and somewhat slabby, splitting up into uneven slabs $1 \frac{1}{2}$ to 5 or 6 inches in thickness and distinctly conchoidal in the oblique or vertical fractures. Occasional cuticles, mostly from stigmarias, are seen on the rather glassy and wavy bedding planes. Two analyses $(91,92)$, the latter quoted from Lord, are given on page 23.

Miscellaneous occurrences.-Crandall ${ }^{3}$ mentions cannel coal on Toms Creek (location 7 ?), on Lick Branch, on Daniel Creek (location 8), and on Jenny Creek (location 5 ?). The Lick Branch eannel is given as 27 inches thick (fig. 15, section 98 ) and, as shown by the analysis, is a semicannel; that on Daniel Creek is 22 inches thick (fig. 15, section 99), and that on Jenny Creek is 24 inches thick (fig. 15 , section 100).

Flambeau.-At the Flambeau mine (location 9) the cannel coal has a thickness of 1 foot 6 inches to more than 4 feet 3 inches and overlies 4 to 6 inches of bituminous coal (fig. 15, sections 101, 102). The cannel is described as clean, carrying no impurities. Lord ${ }^{4}$ gives the analyses (93 and 94) quoted on page 23.

\section{MORGAN COUNTY.}

For many years Morgan County has been the principal source of cannel coal in the United States. Kentucky (pp. 52-53) has long produced nearly as much cannel coal as all the other States combined,

1 Crandall, A. R., Kentucky Geol. Survey Bull. 4, pp. 34-35, 1905.

2 White, Darid, and Thlessen, Reinhardt, The origin of coal: Bur. Mines Bull. 38, pp. 44, 253-256, 1913.

3 Crandall, A. R., Kentucky Geol. Survey, 2d ser., vol. 6, pt. 5, p. 15 [329], [1880]

sLord, N. W., and others, Analyses of coals in the United States: Bur. Mines! Bull. 22, pts. 1 and 2,pp. 104, 540, 1913. 
and Morgan County has produced more cannel coal than all of the other counties of the State combined. Most of this coal is found near the south edge of the county in the district around Cannel City.

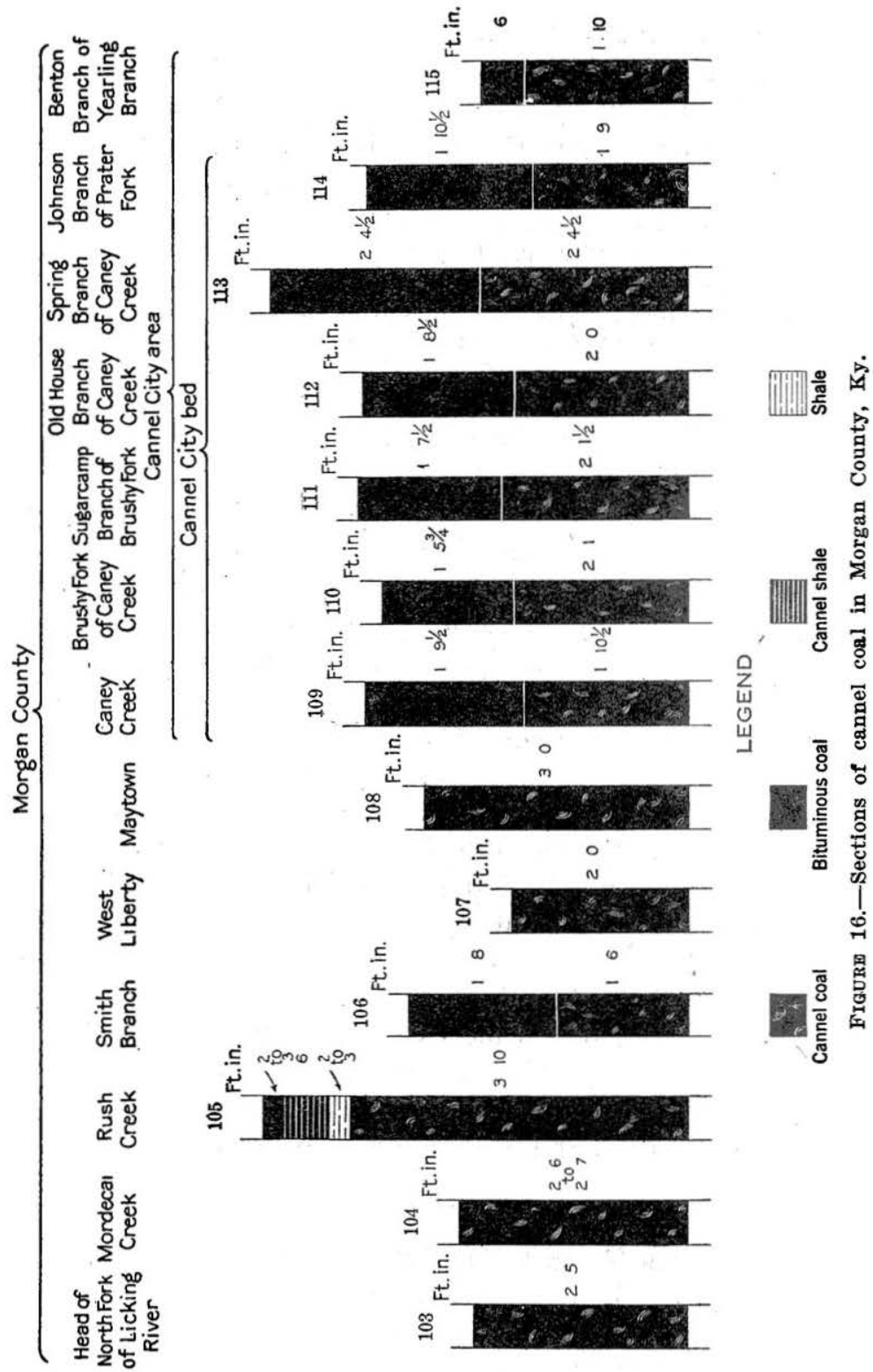

North Fork.-A large body of cannel appears to lie between the head of North Fork of Licking River and Elk Fork (locations 1, 2, and 3). It has been mined commercially by the North Fork Cannel 
Coal Co. at Wrigley. It has been exposed at the head of the main fork (location 1), on Mordecai Creek (location 2), on Rush Creek (location 3), on Smith Branch, and on part of Lick Creek, and it may extend from Rush Creek through the ridge to the head of Straight Creek. Its thickness on main North Fork ranges from 29 to 39 inches or more (fig. 16, section 103). On Lick Creek its thickness is about 20 inches and at Mordecai Creek from 30 to 31 inches (fig. 16, section 104). Rush Creek openings show a greater thickness (fig. 16, section 105), ranging from 34 inches at the lower forks to 46 inches or more a half mile up the ravine on the right side. ${ }^{1}$ Other measurements on Mordecai Creek give up to 36 inches and on Rush Creek up to 58 inches. ${ }^{2}$

Smith Branch.-The cannel coal has been opened ${ }^{3}$ on Smith Branch of Open Fork of Paint Creek (location 4), half a mile above the mouth, showing 18 inches of cannel overlain by 20 inches of splint coal (fig. 16, section 106).

West Liberty.-Cannel coal, 18 to 24 inches thick (fig. 16, section 107), has been mined for local supply at West Liberty on the Cox and Cecil places in the ridge between Licking River and Caney Creek $^{4}$ (location 10).

Spaws Creek.-On Spaws Creek (location 11), which enters Licking River just above West Liberty, a bed of cannel is reported by Crandall ${ }^{5}$ to be 18 inches thick.

Maytown.-Three feet of cannel coal (fig. 16, section 108) is reported by Crandall ${ }^{5}$ to have been found on the Pierat place, east of Maytown (Blackwater of the older maps) (location 9). An analysis (115) is given on page 24 .

Cannel City.-Cannel City (locations 5, 6, 7, 8, 12, and 13) is the center of what is probably the most extensive cannel-coal mining in the United States, and the area of the coal (fig. 17) is the most extensive yet developed in the State.

The coal, which is a semicannel, as shown by the analyses (116124, pp. 24-25), has been mined commercially by the Kentucky Block Cannel Coal Co. and the Watson Cannel Coal Co., of Cannel City, the Gish Cannel Coal Co., of Piedmont, and the Bigstaff Cannel Coal Co., of Bigstaff. Crandall ${ }^{6}$ gives sections of the coal as follows (see fig. 16) :

Caney Creek, drift 3, above the mouth of Prater Fork, coal 44 inches, of which $22 \frac{1}{2}$ inches is cannel (section 109). Brushy Fork

${ }^{1}$ Crandall, A. R., Kentucky Geol. Survey Bull. 10, pp. 6-8, 1910.

2 Crandall, A. R., Kentucky Geol. Survey, 2d ser., vol. 6, pt. 5, p. 15 [329], [1880].

${ }^{8}$ Crandall, A. R., Kentucky Geol. Survey Bull. 10, p. 12, 1910.

1 Idem, p. 15.

5 Crandall, A. R., Kentucky Geol. Survey, 2d ser., vol. 6, pt. 5, p. 15 [329], [1880].

- Crandall, A. R., Kentucky Geol. Survey Bull. 10, pp. 13-14, 1910. 
of Caney Creek, Isaac Lykins place, coal $42 \frac{3}{4}$ inches, of which 25 inches is cannel (section 110). Sugarcamp Branch of Brushy Fork of Caney Creek, coal 45 inches, of which $25 \frac{1}{2}$ inches is cannel (section 111). Old House Branch of Caney Creek, Will Ferguson place, coal $44 \frac{1}{2}$ inches, of which 24 inches is cannel (section 112). Drift 11, on Spring Branch of Caney Creek, coal 57 inches, of which $28 \frac{1}{2}$

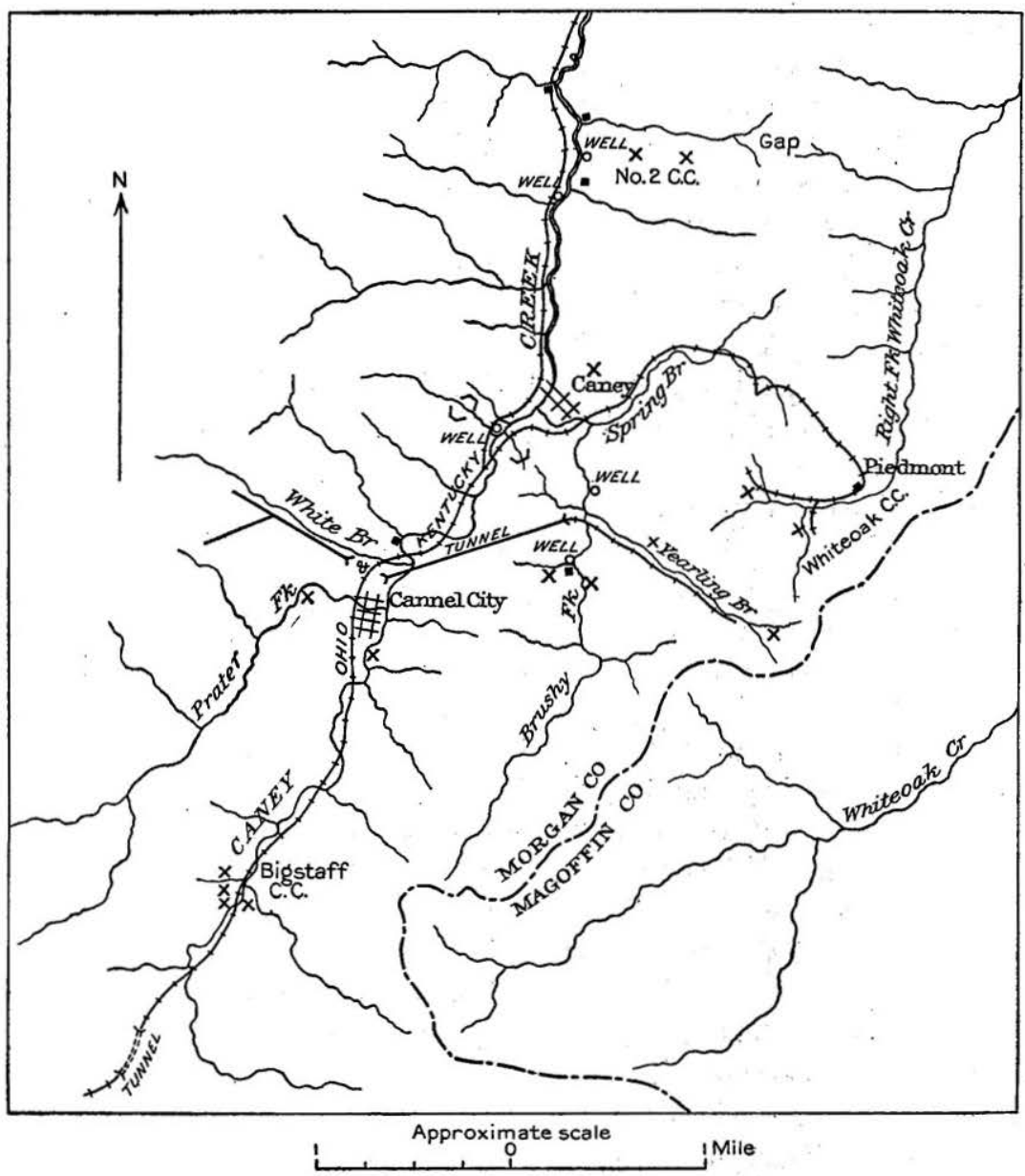

Figure 17.- Sketch map of cannel-coal area around Cannel City, Morgan County, Ky. (After Crandall, Kentucky Geol. Survey Bull. 10, p. 12.)

inches is cannel (section 113). Johnson Branch of Prater Fork of Caney Creek, north side, coal $43 \frac{1}{2}$ inches, of which 21 inches is cannel (section 114). The analyses (116-121, pp. 24-25) show these coals to have about 40 to 41 per cent of volatile matter and 48 to 51 per cent of fixed carbon.

About 200 feet above the main coal is an upper bed measuring 28 inches, of which 22 inches is a true cannel (section 115). (See 
analysisis 124, p. 25.) This upper coal, however, is limited to comparatively small pockets on the head of the right fork of White Oak Creek and Brushy Fork of Caney Creek and to an undeveloped area on the Frozen Creek side. ${ }^{1}$

\section{MAGOFFIN COUNTY.}

Colvin mine.-Cannel coal reported to be 3 feet in thickness (fig. 18, section 117) has been opened on the Colvin place (location 1), on Licking River just above the mouth of Johnson Creek. ${ }^{2}$ An analysis (No. 110) is given on page 24 .

Salyersville.-Near Salyersville (locality 3) a cannel-eoal bed containing 14 inches of cannel coal (analysis 109, p. 24) lies below 18 inches of bituminous coal, the two being separated by a parting (fig. 18 , section 118$)^{3}$

Lykins.--Eighteen inches of cannel coal is reported on Licking River in this county, at the Lykins place, the exact location of which is not known. ${ }^{3}$

WOLFE COUNTY.

Stillwater Creek.-Cannel coal (analyses 139,140, p. 26) is mentioned as found on the John Murphy place on Stillwater Creek (location 1).4

PIKE COUNTY.

Brushy Fork.-Near the top of the ridge between Thompson Branch of Brushy Fork (location 1) and Upper Branch of John

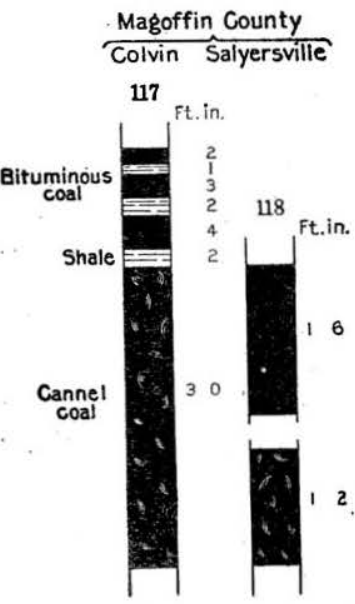

Frgure 18. - Sections of cannel coal in Magoffin County, - Ky.

Creek a coal bed 52 inches thick contains 16 to 17 inches of cannel coal (fig. 19, section 121). On Left Fork of Brushy Fork what is probably the same bed (fig. 19, section 122) contains 27 inches of cannel coal. ${ }^{5}$

Little Brushy Branch.-A little cannel coal (fig. 19, section 123) is reported on Little Brushy Branch of John Creek (location 2), as shown in the section. ${ }^{6}$

Money Branch of Turkey Creek.-Cannel coal exists on Money Branch of Turkey Creek (location 3), being $17 \frac{1}{2}$ inches thick on the left fork and 22 inches thick on the right fork. (See fig. 19, sections 119,120 .) On the left fork the cannel bench is separated by 4 inches

\footnotetext{
${ }^{1}$ Crandall, A. R., Kentucky Geol. Survey Bull. 10, pp. 13-14, 1910.

2 Idem, p. 18.

${ }^{3}$ Crandall, A. R., Kentucky Geol. Survey, 2d ser., vol. 6, pt. 5, p. 15 [329], [1880].

4 Crandall, A. R., Kentucky Geol. Survey Bull. 10, p. 58, 1910.

${ }^{5}$ Crandall, A. R., Kentucky Geol. Survey Bull. 4, p. 87, 1905.

'Idem, p. 48.
} 
of black shale and coal from a bench of semicannel 2 feet thick, which has a $2 \frac{1}{2}$-inch parting near the middle. On the right fork the lower bench is all bituminous coal, 21 inches thick. ${ }^{1}$
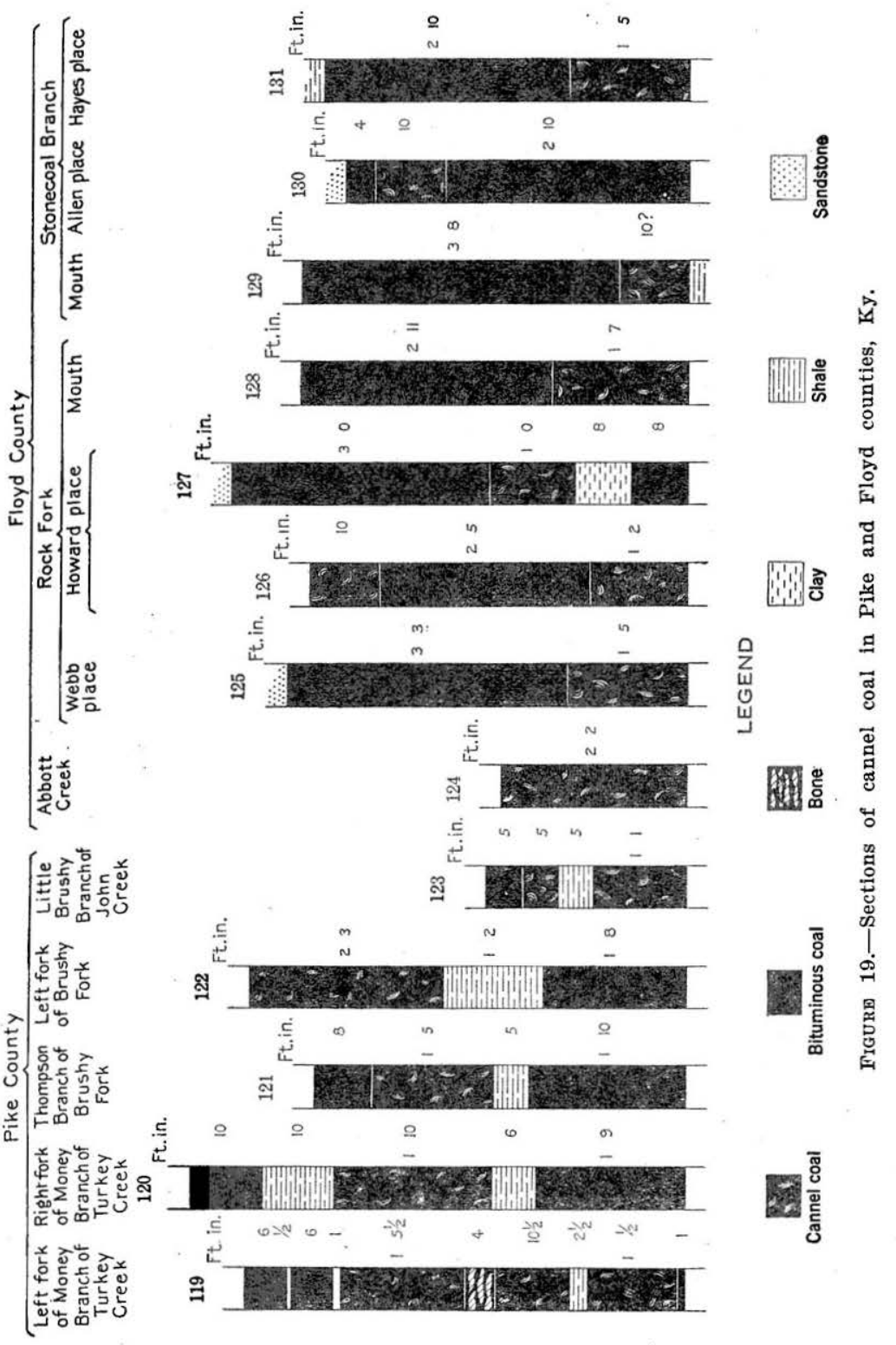

FLOYD COUNTY.

Abbott Creek.-Crandall ${ }^{2}$ reports 26 inches of cannel coal on Abbott Creek (location 1). (See fig. 19, section 124.)

${ }^{1}$ Hoeing, J. B., Kentucky Geol. Survey, 4th ser., vol. 1, pt. 1, p. 230, 1913.

${ }^{2}$ Crandall, A. R., Kentucky Geol. Survey, 2d ser., vol. 6, pt. 5, p. 15 [329], [1880]. 
Rock Fork of Right Fork of Beaver Creek.-Cannel coal has been opened at a number of places on Rock Fork (location 2 ?). At the mouth of this fork an opening shows 19 inches of cannel (fig. 19, section 128), overlain by 35 inches of bituminous coal. On the B. Howard place one opening shows 12 inches of cannel under 3 feet of bituminous coal and another shows 29 inches of bituminous coal between an upper bench of cannel 10 inches thick and a lower bench 14 inches thick. (See fig. 19, sections 126, 127.) On the R. Webb place the same bed (fig. 19, section 125) carries 17. inches of cannel under 39 inches of bituminous coal. ${ }^{1}$

Stone Coal Branch of Right Fork of Beaver Creek.-The Van Lear coal carries from 10 to 17 inches of cannel near the mouth of Stone Coal Branch (location 3). At the mouth 10 inches of cannel underlies 44 inches of bituminous coal. (See fig. 19, section 129.) On the G. Allen land a similar thickness of cannel overlies 34 inches of bituminous coal. (See fig. 19, section 130.) On A. Hayes land, above Stone Coal Branch, 17 inches of cannel underlies 34 inches of bituminous coal. ${ }^{2}$ (See fig. 19; section 131.)

Prestonburg.-Owen ${ }^{3}$ noted a cannel coal opposite Prestonburg (locations 4, 5) 98 feet above the river. He reports seeing cannel both above and below town, the thickness ranging from 2 feet 8 inches to 3 feet 4 inches.

BREATHITT COUNTY.

Nichols Fork of Frozen Creek.-Cannel coal has been noted at many points along the hillsides near the head of Frozen Creek (location 7). Its thickness has not been determined, but blocks found on the hillside indicate a thickness of at least 2 feet. Two varieties of cannel were noted in this region; one is "hard and very uniform, rather coarse grained structure, showing perfect conchoidal fracture, and abounding in brilliantly polished surfaces or slickensides"; the other "shows a partially laminated structure, irregular fracture, and is of a less homogeneous nature and not nearly so handsome, but it proves on analyses to be one of the best cannel coals of this whole region. It is commonly called the 'curly cannel' owing to its peculiar structure." 4 Analyses $(50,51)$ are given on page 22 .

Jackson.-One of the highest-grade cannel coals of the :State has been found within a mile of Jackson on the Joe Little place (location 13). Unfortunately the bed is thin, containing only from 10

\footnotetext{
1 Hoeing, J. B., Kentucky Geol. Survey, 4th ser., vol. 1, pt. 1, pp. 146-147, 1913.

2 Idem, p. 147.

3 Owen, D. D., Kentucky Geol. Survey Rept. for 1854 and 1855, p. 208, 1856.

4 Crandall, A. R., Coals of the Licking Valley region: Kentucky Geol. Survey Bull. 10, p. $58,1910$.
} 
to 16 inches of cannel and underlying only a very few acres (fig. 20, section 132). It has a-

bright, slick, satiny appearance and, on being burned, goes entirely into fine red ash. This is the richest and purest cannel coal that the writer ${ }^{1}$ has found in Kentucky, and it is probably unsurpassed anywhere. Sad to relate, a close and careful investigation of the pocket and adjoining hills reveals the existence

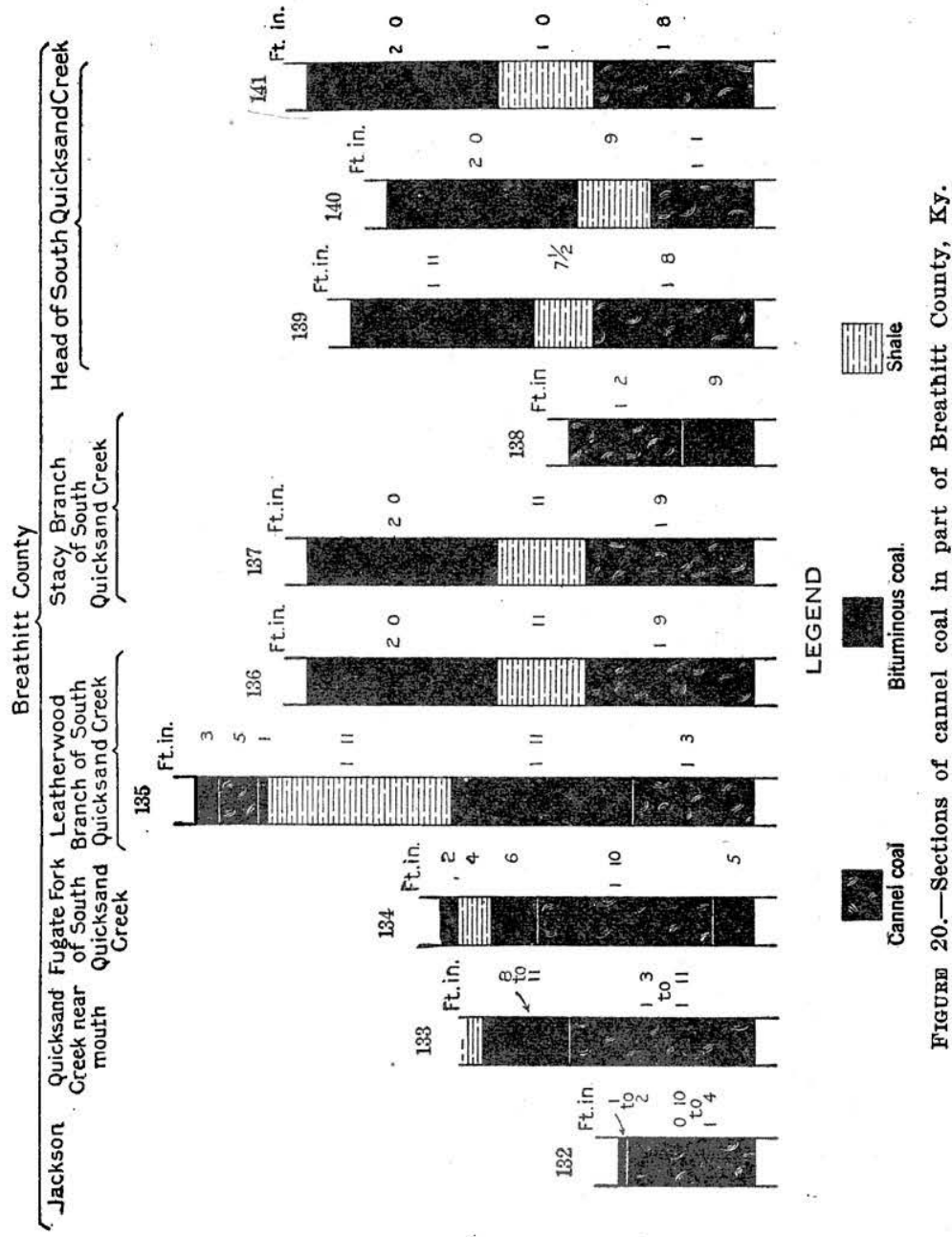

of only about 3 acres of this remarkable coal, another commentary upon the disappointment to which a searcher for this elusive mineral is subjected.

According to an analysis (56, p. 22) by the Consolidated Gas Co. of New York this coal contains 68 per cent of volatile matter and only 28 per cent of fixed carbon and 3.8 per cent of ash. ${ }^{2}$ Analyses of Jackson coal $(55,56)$ are given on page 22 .

\footnotetext{
${ }^{1}$ Hendrie, Charles, Some Kentucky cannels : Kentucky Inspector of Mines Tenth Ann. Rept., p. 143, 1894.

2 Fohs, F. H., Kentucky Geol. Survey Bull. 18. p. 35, 1912.
} 
Quicksand Creek.-About a mile above the mouth of Quicksand Creek (locations 6 and 9 ) there is a bed of cannel coal 25 to 26 inches thick, including 8 inches of bituminous coal at the top. From this point the coal extends along the right side of Quicksand Creek for about 3 miles, the cannel part of the bed ranging from 15 to 23 inches and the bituminous from 8 to 11 inches. (See fig. 20, section 133.) The coal, which is a fine cannel (analysis 49 , p. 22), was shipped to market many years ago by barges. The cannel is rather restricted in area, but it has been found on Smith Branch of South Quicksand Creek, where the lower layer is a semicannel.1

Fulgate Fork.-A pocket of cannel coal (fig. 20, section 134) on Fulgate Fork of South Quicksand Creek (location 10) shows 22 inches of cannel, with bituminous coal both above and below. ${ }^{2}$

Leatherwood Branch.-Both the Wilson Fork and Whitesburg coals carry cannel on Leatherwood Branch of South Quicksand Creek (location 11). The Wilson Fork bed (fig. 20, section 136) shows 21 inches of cannel overlain by 11 inches of shale and 24 inches of bituminous coal and the Whitesburg coal (fig. 20, section 135) contains 15 inches of cannel in one bench and 5 inches associated with bituminous coal in another. ${ }^{3}$

Stacy Branch.-Two beds carry cannel on Stacy Branch (location 14), which enters South Quicksand Creek less than one-fourth of a mile above Leatherwood. The Wilson Fork bed shows 21 inches of cannel in exactly the same section (fig. 20, section 137) as that on Leatherwood Branch. The next coal above shows 14 inches of cannel over 9 inches of bituminous coal (fig. 20, section 138). The Wilson Fork cannel here is of very high grade, as shown by the analyses $(57,58,58 \mathrm{a}$, p. 22). It is "bright and slick in appearance, ignites readily with a match, and is of excellent quality." The Dictator Cannel Coal Co. is working it at this point. ${ }^{4}$ Half a mile farther up Stacy Branch another opening on this bed shows $12 \frac{1}{2}$ inches of cannel overlain by 20 inches of bituminous coal. 5

South Quicksand Creek.-Cannel coal appears abundantly along South Quicksand Creek (location 12) above the mouth of Leatherwood Branch. The following sections show the character of the Wilson Fork coal: Three-fourths of a mile above the mouth of Leatherwood Creek, coal 23 inches, shale $7 \frac{1}{2}$ inches, cannel coal (at bottom) 20 inches (fig. 20, section 139); on the opposite side of the creek, in a small branch, coal 24 inches, shale 9 inches, cannel 13

\footnotetext{
${ }^{1}$ Cranđall, A. R., Kentucky Geol. Survey Bull. 10, p. 59, 1910. Fohs, F. H., Kentucky Geol. Survey Bull. 18, p. 37, 1912.

2 Fohs, F. H., op. cit., p. 24.

${ }^{3}$ Idem, p. 28.

${ }^{4}$ Idem, pp. 30-32.

${ }^{5}$ Hendrie, Charles, Kentucky Inspector of Mines Tenth Ann. Rept., pp. 140-141, 1894. $87775^{\circ}-18-B u l l .659-7$
} 
inches (fig. 20, section 140); on Wilson Fugate Branch, still higher up South Quicksand Creek, coal (mainly splint) 24 inches, shale 12 inches, cannel coal 20 inches (fig. 20, section 141).

The Haddix bed on Wilson Fugate Branch shows 11 inches of cannel on the John Clemmons farm, where the Whitesburg coal con-

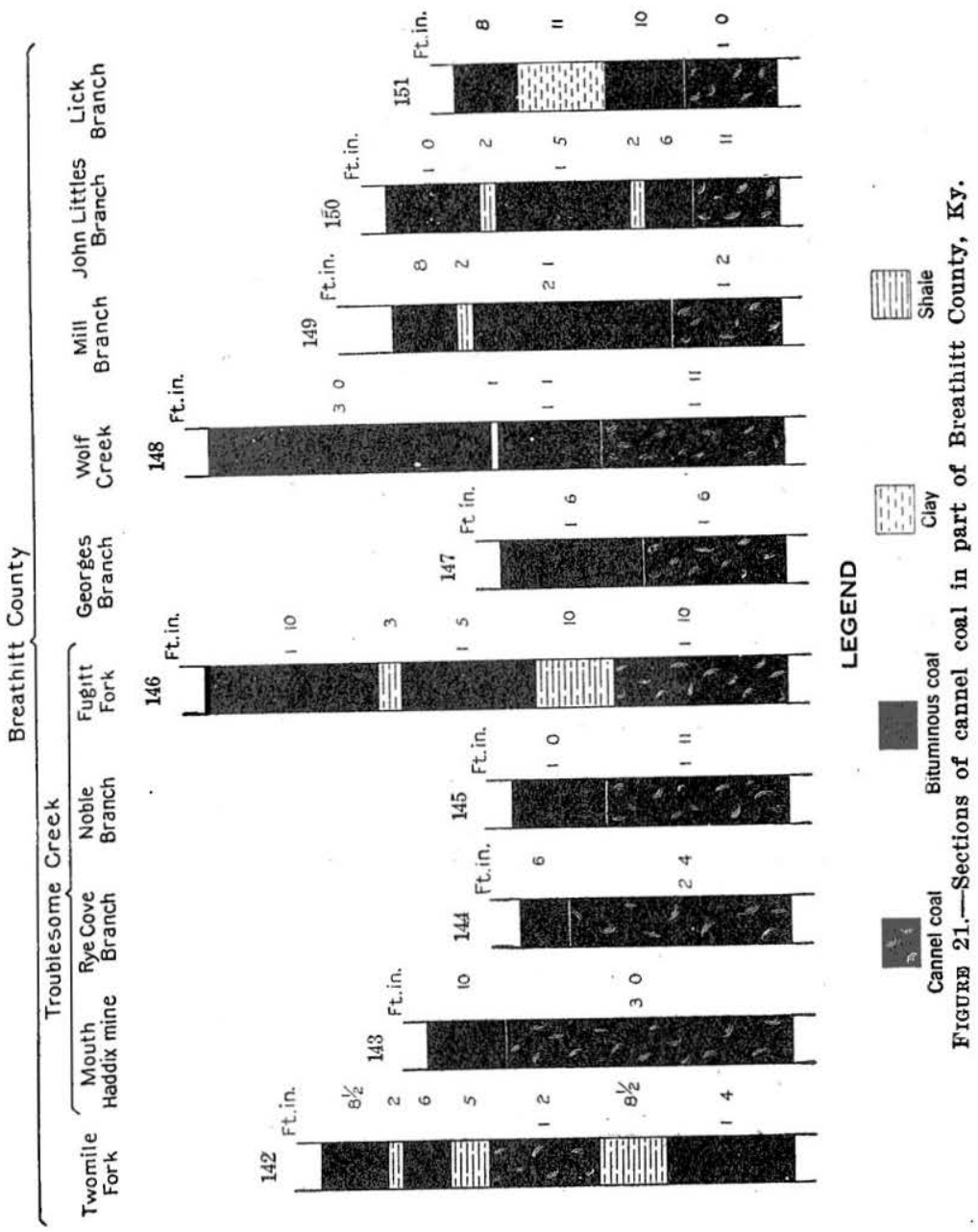

tains two 6-inch benches, and the Wilson Fork bed, 20 feet higher, 1 foot of cannel. This pocket appears to contain, all told, about 300 acres of workable cannel of very high grade. ${ }^{1}$.

Twomile Fork.-The Haddix coal has been opened on Twomile Fork (location 16), about 4 miles above the mouth of Leatherwood, at the Alfred Fugate place (fig. 21, section 142), where it shows 14 inches of cannel in a 5 -foot bed of coal. ${ }^{2}$

${ }^{1}$ Hendrie, Charles, Kentucky Inspector of Mines Tenth Ann. Rept., p. 142, 1894.

2 Idem, p. 30. 
Troublesome Greek.-Cannel coal was formerly mined at the mouth of Troublesome Creek at the Haddix mine (location 1) and boated down Kentucky River. At the main opening 21 inches of cannel is overlain by 12 inches of bony cannel and 14 inches of bituminous coal. 1 One section (fig. 21, section 143) gave 36 inches of cannel under 10 inches of bituminous coal. ${ }^{2}$ Other measurements on this bed in this neighborhood show the variableness of cannel coal. An entry driven 300 yards through the hill to Rye Cove Branch ran out of coal, and another opening on the same bed 100 yards away showed 28 inches of cannel with 6 inches of bituminous above (fig. 21, section 144). A little higher up the branch the coal is 20 inches thick and all bituminous. On the opposite side of Rye Cove the same bed shows 18 inches of bituminous coal and no cannel. Another opening farther down on the same side showed 37 inches of clean, hard, bituminous coal with no cannel; but several hundred yards farther down, an opening shows 35 inches of cannel under 10 inches of bituminous coal. This pocket has been estimated to contain about 50 acres of cannel. ${ }^{8}$ Analyses (34-39) are given on page 21.

Noble Branch:-On Noble Branch of Troublesome Creek (location 2) a bed, which may be the Haddix, shows 23 inches of cannel under 12 inches of bituminous coal (fig. 21, section 145): This cannel, which occurs on the Sewell and Little place, is of good quality, as shown by the analysis $(40$, p. 21$) .^{4}$

Fugitt Branch.-On Troublesome Creek, at the mouth of Fugitt Branch, on the Roberts place (location 3), is a thick bed (fig. 21 , section 146) containing 22 inches of cannel, which, as shown by the analysis ( 41, p. 21$)$, approaches semicannel in character. It is described as "a pure-looking coal with but little fibrous coal, and no apparent pyrites. Sample somewhat mixed in character. Some pieces of cannel coal, others splint coal, others apparently shaly."

Georges Branch.-Five miles south of the mouth of Troublesome Creek is the Georges Branch deposit (location 4), one of the most important in the State. The coal regularly and persistently outcrops about 140 feet above drainage for $1 \frac{1}{2}$ miles up the creek. This coal had been shipped down the river for many years before a railroad was built into this section. On the Georges Branch Cannel Coal Co.'s land, half a mile from the mouth of the stream, the coal shows 18 inches of cannel, overlain by 8 inches of splint and 12 inches of bituminous coal (fig. 21, section 147). The cannel bed is a "beauti-

1 Hendrie, Charles, op. cit., p. 132 .

a Hodge, J. M., Report on the coals of the three forks of the Kentucky River: Kentucky Geol. Survey Bull. 11, p. 26, 1910.

${ }^{3}$ Hendrie, Charles, Kentucky Inspector of Mines Tenth Ann. Rept., p. 132, 1894.

« Hodge, J. M., Kentucky Geol. Survey Bull. 11, pp. 28-29, 1910.

5 Idem, pp. 45-46. 
ful, clean, bright cannel coal, tough and elastic." On the Stone Coal Fork of Georges Branch a section showed cannel $18 \frac{1}{2}$ inches and coal 17 inches. $^{1}$ One mile up Georges Branch there was measured a cannel coal, 17 inches; splint coal, 17 inches; bituminous coal, 3 inches. Apparently Georges Branch runs through the center of the basin, the cannel coal having a nearly regular thickness of 14 to 20 inches. A mile to the south, on the river, the coal is thin and has passed into a slaty cannel; and on the north side of Wolf Creek, the next stream to the south, the coal is a thin semicannel. The basin has been estimated to contain 375 acres of cannel coal. Analyses (43-47) are given on pages $21-22 .^{2}$

Wolf Creek.-On the south side of Wolf Creek (location 5) the cannel is 23 to 27 inches thick (fig. 20, section 148). By its appearance and analysis, however, it here approaches semicannel. ${ }^{3}$ (See analysis 48 , p. 22.)

Miscellaneous occurrences.-Many deposits showing a foot or less of cannel occur throughout Breathitt County. Sections of two of these deposits between Lost Creek and North Fork and of one west of North Fork are given in figure 21-section 149, on Mill Branch (location 18) ; section 150, at John Littles Branch (location 19); and section 151, on Lick Branch (location 17). At all these places, as at others, the coal is so resistant that blocks of it accumulate in quantities that give the impression of a greater bed than exists: ${ }^{4}$

\section{JACKSON COUNTY.}

Cannel coal has been found at several points in Jackson County. In the valley of Grassy Creek (location 1), in the northeast corner of the county, 14 inches of cannel coal occur on the William Bowles place. Cannel coal is also found on Pond Creek (location 2), not far from the Settle store, Annville (?). ${ }^{5}$

Among the coals analyzed by the Kentucky Geological Survey are two $(87,88$, p. 23 ) from this county, one of which is described as follows: "Cannel coal from Tom Cole's bank, 17 miles southeast of Richmond (location 3), represented to be 21 inches cannel and 21 inches bituminous coal. * * * Rather dull looking cannel coal, splitting with difficulty into layers with not enough fibrous coal to soil the fingers and with no apparent pyrites." The other coal is described as follows: "Cannel coal from T. J. Ballard's place,

\footnotetext{
${ }^{1}$ Hendrie, Charles, Kentucky Inspector of Mines Tenth Ann. Rept., p. 134, 1894.

${ }^{2}$ Hendrie, Charles, idem. Hodge, J. M., Kentucky Geol. Survey Bull. 11, pp. 70-71, 1910. Crandall, A. R., Kentucky Geol. Survey Bull. 10, p. 65, 1910.

${ }^{\mathrm{s}}$ Hendrie, Charles, op. cit., pp. 134-135. Hodge, J. M., op. cit., pp. 72-73.

4 Hodge, J. M., Preliminary report on the geology of the lower North Fork, Middle and South forks, Kentucky River, p. 90, Kentucky Geol. Survey, 1887.

${ }^{5}$ Miller, A. M., Coals of the lower measures along the western border of the eastern coal field: Kentucky Geol. Survey Bull. 12, pp. 75-76, 1910.
} 
branch of Horselick, 26 miles from Richmond (location 4). * * * Specimen from the outcrop. *** Resembles the preceding, has a bird's-eye structure in parts." ${ }^{1}$

\section{LETCHER COUNTY.}

Mill Branch of Rockhouse Creek.-On the J. Q. Bentley place, at the mouth of Mill Branch (location 6), and again at the mouth of

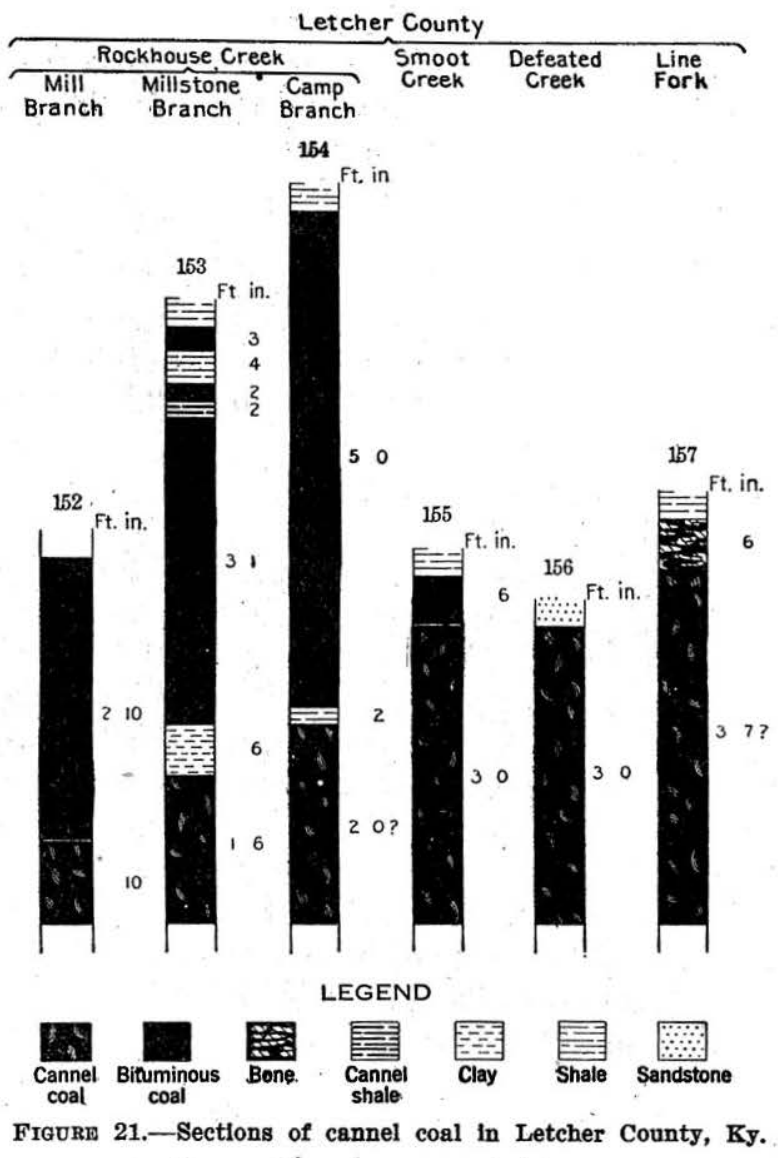

Potters Fork, the Elkhorn coal carries 10 inches of semicannel coal under 34 inches of bituminous coal ${ }^{2}$ (fig. 22, section 152, and analysis 106, p. 24).

Millstone Branch of Rockhouse Creek.-The "fire-clay" or Dean coal on Millstone Branch (location 3) carries at its base 18 inches

\footnotetext{
${ }_{1}^{1}$ Peter, Robert, Chemical analyses : Kentucky Geol. Survey Rept. A, pt. 1, pp. 272-273, 1884.

2 Hodge, J. M., Kentucky Geol. Survey Bull. 11, p. 145, 1910.
} 
of cannel without partings, described as a fine-looking coal ${ }^{1}$ (fig. 22, section 153 , analysis 104 , p. 24).

Camp Branch of Rockhouse Creek.-On Camp Branch, on the J. N. Collins place (location 4), the cannel at the base of the Dean coal is 2 feet thick ${ }^{2}$ (fig. 22).

Smoot Creek.-Near the mouth of Smoot Creek (location 5) the Whitesburg is a cannel coal 18, inches to 3 feet thick (fig. 22 , section 155$).^{3}$

Defeated Creek.-The Dean coal is mostly cannel on Defeated Creek (locations 1 and 2). Where it goes under the creek it measures 3 feet of solid cannel under a massive sandstone (fig. 22, section 156). On the Ira Hall place, 2 miles above the mouth, it is 25 inches thick, including 3 inches of shale 7 inches from the top. ${ }^{4}$ (See analysis 105, p. 24.)

On Line Fork, 2 miles above the mouth of Defeated Creek, on the Joseph Cornett place (location 1), the bed shows 43 inches of highash cannel (analysis 103, p. 24), grading into bituminous shale at the top (fig. 22, section 157). It is described as "a bright, rather pure looking cannel." 5

\section{LESLIE COUNTY.}

Cutshin Creek.-Six miles above Paul Creek, on Coon Creek (location 1), the Dean or "fire-clay" coal carries 32 inches of cannel under 6 inches of bituminous coal (fig. 23, section 158). Hodge ${ }^{6}$ says this bed "though rare as cannel on the Middle Fork (of Kentucky River) is quite common as such on the North Fork, and the rider has cannel to the southwest on Greasy Creek and elsewhere."

Laurel Fork.-Three miles up Laurel Fork and one-eighth of a mile to the left up Wolfpen Branch and 50 feet above it, on the Arch Cornett place (location 3), is 23 inches of cannel, with 28 inches of bituminous above and 16 inches of bituminous below (fig. 23, section $159)$. One analysis given $(100$, p. 24$)$ is of the cannel bed; another (101) is of the cannel bed and the 6-inch bed of bituminous coal immediately below. ${ }^{7}$

Beech Fork.-On Oldhouse Branch of Beech Fork of Middle Fork of Kentucky River (location 2), the rider of the "fire-clay" coal is a cannel 38 inches thick (fig. 23, section 160, and analysis 102, p. 24$).^{8}$

\footnotetext{
${ }^{1}$ Hodge, J. M., Kentucky Geol. Survey Bull. 11, p. 135, 1910.

2 Idem, p. 137.

3 Idem, p. 150.

4 Idem, p. 126.

5 Idem, p. 127.

6 Idem, p. 195.

7 Idem, p. 196.

s Idem, p. 222.
} 
PERRY COUNTY.

Lots Creek.-On Lots Creek, near Grigsby (location 1), 21 inches of cannel underlies 23 inches of bituminous coal (fig. 23, section 162 ) in what seems to be a fair-sized pocket. An analysis (131) is given on page 25 .

Lost Creek.-On Lost Creek (location 2) two coals (Nos. 4 and 5) carry cannels. The cannel with coal No. 4 is generally thin; that with No. 5 is 10 to 22 inches thick, with a considerable thick-

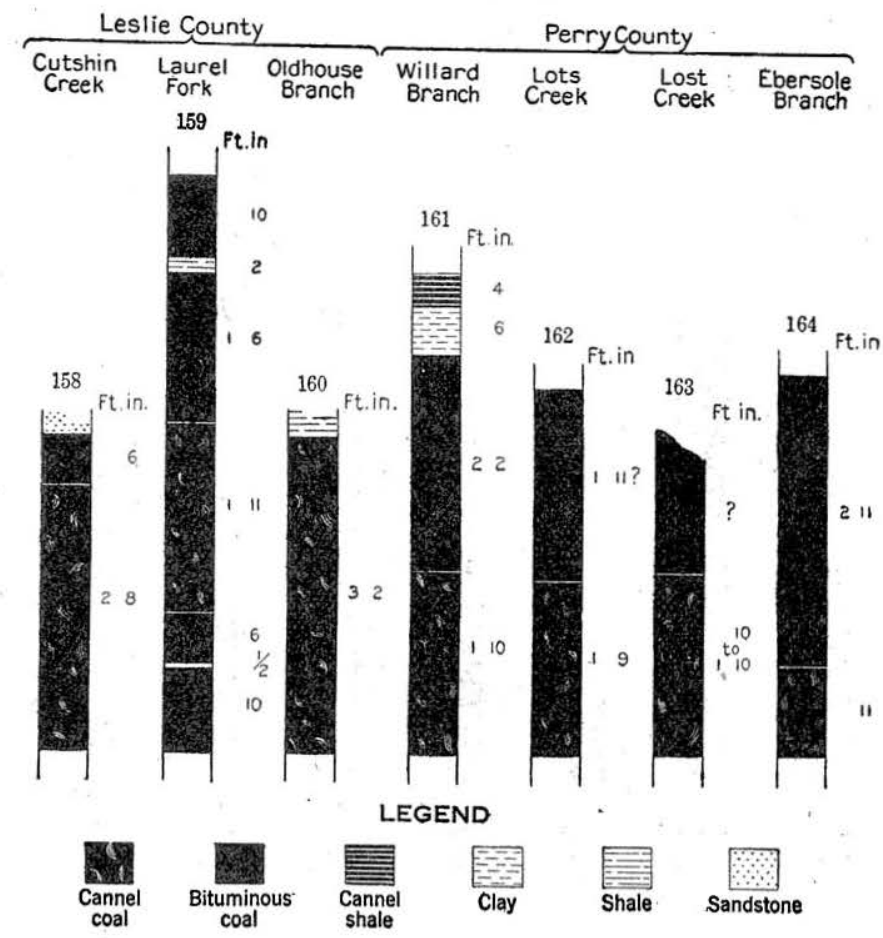

Figdra 23.-Sections of cannel coal in Leslie and Perry counties, Ky.

ness of bituminous coal above (fig. 23 , section 163), but the cannel is not of first-class quality. ${ }^{1}$

Ebersole Branch.-On Ebersole Branch of North Fork of Kentucky River (location 3), 11 inches of cannel underlies 35 inches of bituminous coal (fig. 23, section 164). ${ }^{2}$

Squabble Branch.-The same bed shows some cannel on Squabble Branch of Middle Fork of Kentucky River (location 4). Blocks of cannel at an old opening a mile from the mouth of the creek indicate the presence of some good cannel coal. ${ }^{2}$

\footnotetext{
${ }^{1}$ Hendrie, Charles, Kentucky Inspector of Mines Tenth Ann. Rept., p. 143, 1894.

2 Hodge, J. M., Preliminary report on the geology of the lower North Fork, Middle and South forks, Kentucky River, p. 83, Kentucky Geol. Survey, 1887.
} 
North Fork of Kentucky River.-Eight inches of cannel coal occur on the Elijah Davidson place, 3 miles above the mouth of Grapevine Creek. On the Samuel Whittaker place (locality 5), on Willard Branch, the same bed contains 22 inches of cannel. (See fig. 23, section 161.)

Harlan County

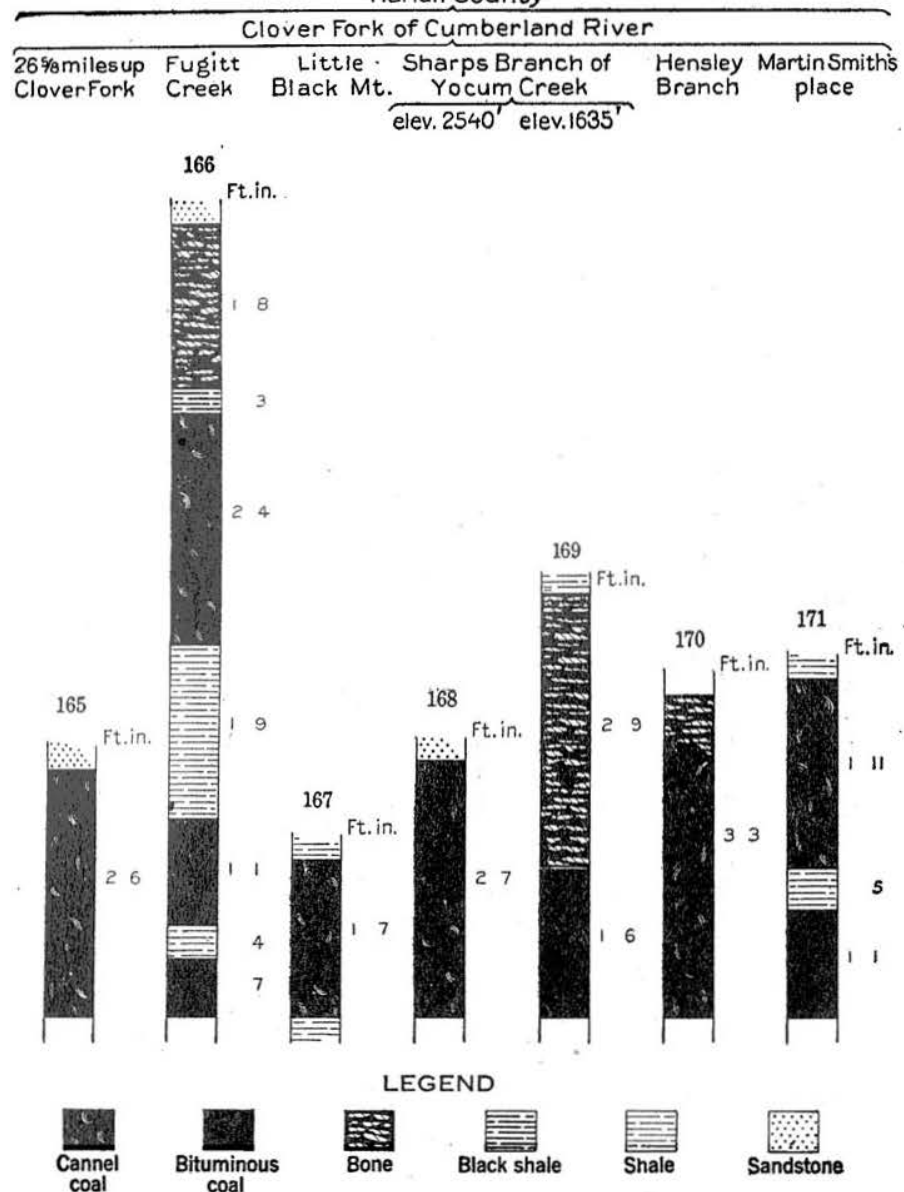

Frgure 24.- Sections of cannel coal on Clover Fork of Cumberland River, Harlan County, Ky.

Middle Fork.-On Middle Fork of Kentucky River (location 6) a mile below the mouth of Rush Creek 10 inches of cannel coal inclosed in 24 inches of bituminous coal is found. ${ }^{1}$ An analysis (132) is given on page 25 .

\section{HARLAN COUNTY.}

Jack Bailey Branch.-On the Wright Short place, $26 \frac{5}{8}$ miles above the mouth of Clover Fork, at the mouth of Jack Bailey Branch (loca- 
tion 6), is found 30 inches of cannel (fig. 24, section 165) in the Kelioka coal (Keokee of State reports). The basin seems to be very small, for 150 yards away an opening shows only 11 inches of cannel and 24 inches of bituminous coal. ${ }^{1}$

Fugitt Creek.-About one-fourth of a mile up Fugitt Creek (location 5), about 7.50 feet above sea level, a bed (fig. 24, section 166) contains 28 inches of cannel of doubtful quality and 20 inches of cannel-like shale associated with some bituminous coal and much shale. $^{2}$

Little Black Mountain.-On Little Black Mountain, below the mouth of Fugitt (location 4), the Kelioka coal (fig. 24, section 167) is only 19 inches thick but is all cannel. ${ }^{3}$

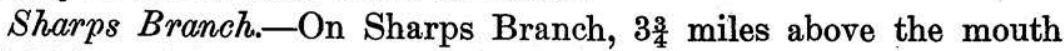
of Yokum Creek, in Horse Hollow of the Left Fork (location 3), 31 inches of cannel coal lies about 2,540 feet above sea level. Farther down the same branch, at about 1,635 feet, 15 inches of cannel shale is underlain by 25 inches of bituminous coal. At another opening near by the shaly cannel is 33 inches in thickness. The upper bed on Bailey Creek is also partly cannel. ${ }^{4}$ (See fig. 24, sections 168, 169, and analysis 82, p. 23 .)

Hensley Branch.-The Kelioka bed is a cannel coal on Hensley Branch (location 1) 2 miles above the mouth of Clover Fork. It is here 39 inches thick (fig. 24, section 170), the upper part, however, grading over into a cannel shale. ${ }^{5}$

Clover Fork.-On the Martin Smith place, $1 \frac{1}{2}$ miles above the mouth of Hensley Branch (location 2), the Kelioka bed (fig. 24, section 171) carries 23 inches of cannel separated by 5 inches of shale from 13 inches of bituminous coal. ${ }^{6}$

Lick Branch of Poor Fork.-On Lick Branch (location 7) the Kelioka bed shows 28 inches of cannel of good appearance, light weight, and good fracture, overlain by 33 inches of cannel shale (fig. 25, section 172). It is said that a piece of this cannel, about 6 to 8 inches cube, when broken open was found to contain in the middle a lump of pure splint coal 1 by 2 by 3 inches.?

Johns Branch of Catron Creek.-On Johns Branch, on the Myra Osburn place (location 15), 40 feet above the Harlan coal 30 inches of cannel is overlain by 22 inches of bituminous coal. Other measurements on Johns Branch have shown 2 feet 9 inches of cannel overlain

\footnotetext{
1 Hodge, J. M., The upper Cumberland coal fleld: Kentucky Geol. Survey Bull. 13, p. $108,1912$.

2 Idem, p. 82.

3 Idem, p. 80.

4 Idem, pp. 51-52.

${ }^{5}$ Idem, p. 38.

Idem, p. 39.

7 Idem, p. 152.
} 
by 21 inches of bituminous coal. (See fig. 25 , section 173 , and analysis 83, p. 23 .)

An analysis $(84$, p. 23$)$ is of a sample described as taken " 8 miles from Mount Pleasant (Harlan) at the head of Catron Creek of Martin Fork. Sample from 22-inch seam in bed containing three seams, two of stone coal, severally 18 inches and 6 inches thick, sep-

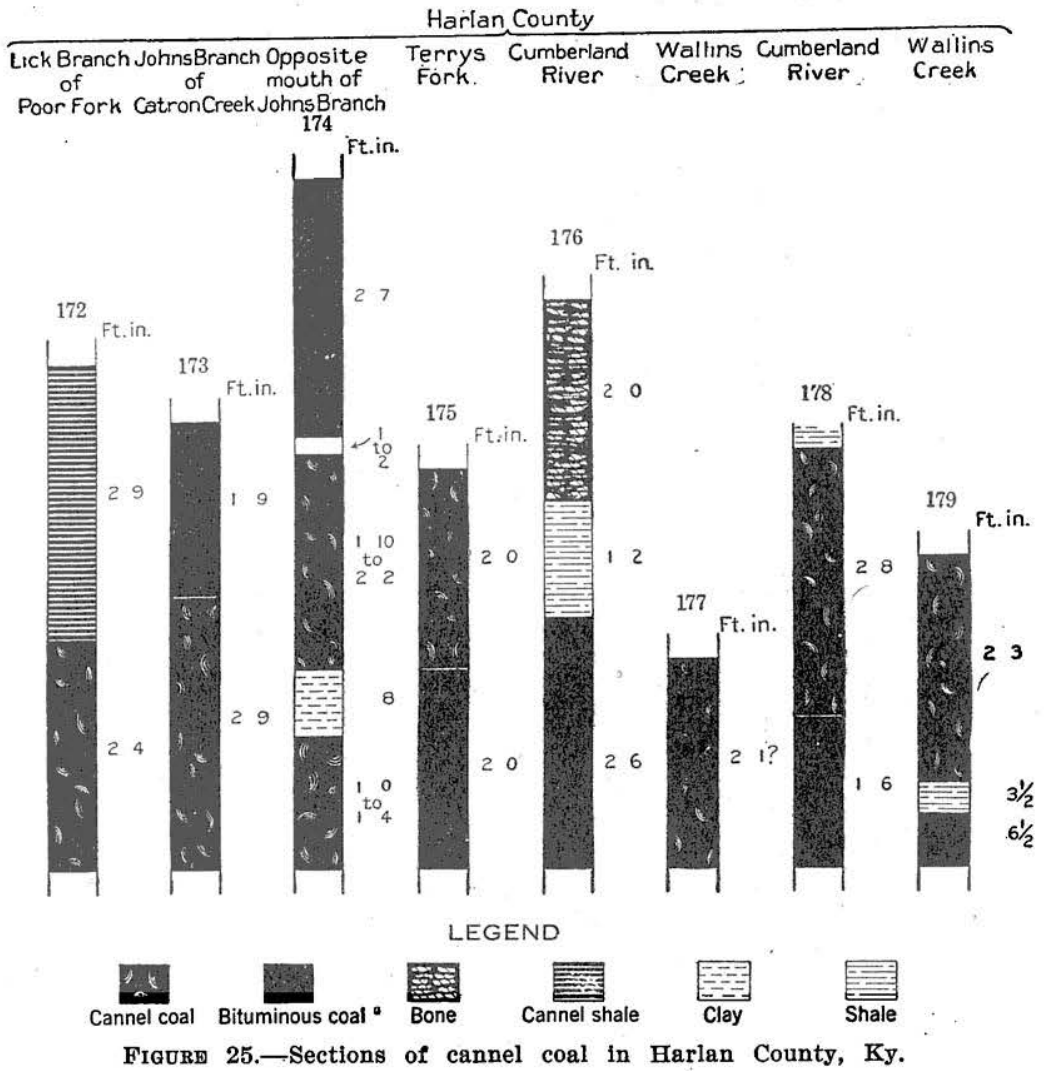

arated by 2 inches of shale parting; 120 feet above drainage; a dull gray-black cannel coal, irregularly laminated." ${ }^{1}$

Catron Creek.-Opposite the mouth of Johns Branch on the Washington Hensley place (location 14) is a good showing of cannel coal. The bed comprises, from the top down, 2 feet to 2 feet 7 inches of bituminous coal, 1 to 2 inches of clay, 22 to 26 inches of cannel (the lower part of which is a good cannel with conchoidal fracture), 8 inches of clay, and 12 to 16 inches of cannel. (See fig. 25, section 174.) Two analyses $(83,86$, p. 23$)$, which include both benches of

${ }^{1}$ Ashley, G. H., and Glenn, L. C., U. S. Geol. Survey Prof. Paper 49, pp. 200-201, 1906. 
cannels, show that these coals, though low in ash, are also low in volatile matter. ${ }^{1}$

Martin Fork near Hurst.-Cannel coal is reported to lie 50 feet above the Harlan coal at the Stephen Place mine on Martin Fork, near Hurst (location 13). As this is on the opposite side of the ridge from the cannel coal at the same horizon on Johns Branch, it is possible that there is a fair-sized area of cannel coal in this district.

Wallins Creek.-What has been called the Terrys Fork coal carries cannel over a good-sized area near the mouth of Wallins Creek. It is typically exposed on Terrys Fork near the mouth (location 8), where it shows a thickness of 24 inches of cannel over 24 inches of bituminous coal, on the Adrian Howard place (fig. 25, section 175). Over the ridge to the northeast on Cumberland River, opposite the mouth of Watts Creek (location 16), the same bed shows 24 inches of shaly cannel over 30 inches of bituminous coal (fig. 24, section 176). Around the divide between Terrys Fork and Wallins Creek on the Wallins Creek side, on Mrs. L. Howard's place (location 9), what is apparently the same bed shows 30 inches of cannel coal overlying 14 inches of shale and 24 inches of bituminous coal. A little farther up Wallins Creek this coal has been opened up, or faced up, at several points (location 17), showing about 25 inches of cannel coal (fig. 25, section 177). Below the mouth of Wallins Creek, on the trail passing over the ridge to Jesse Creek (location 10), the same bed contains 32 inches of cannel above 18 inches of bituminous coal (fig. 25, section 178). On the D. F. Noe place on Wallins Creek (location 12) 27 inches of cannel is reported to overlie $3 \frac{1}{2}$ inches of shale and $6 \frac{1}{2}$ inches of bituminous coal (fig. 25 , section 179). This same coal shows 10 inches of cannel on the Banner Fork of Wallins Creek and 4 inches of cannel on Camp Branch. ${ }^{2}$

\section{BELL COUNTY.}

Pineville.-Cannel coal has been mined on Stewarts Branch near Pineville (locations 1 and 3 ) by the Breckenridge \& Pineville Syndicate (Ltd.), later the Wallsend Coal \& Coke Co., and at present The Federal Coal Co. The cannel bed is what is locally called the McGuire bed, overlying the Dean coal. An analysis (31) is given on page 21. The occurrence of the coal has been described by Crandall as follows: ${ }^{3}$

The McGuire cannel seam, or the Upper Dean coal, at the 762-foot level on Stewart Branch is continuous over a large part of this region, rising to the

1 Ashley, G. H., and Glenn, L. C., op. cit., pp. 196-198.

2 Idem, p. 153.

${ }^{3}$ Crandall, A. R., and Sullivan, G. M., Kentucky Geol. Survey Bull. 14, pp. 106-107, 1912. 
crest of the hills near the head of the Pogue Branch. The cannel portion of the bed is not so constant a feature either in thickness or in quality as to give value to this coal seam. On the right fork of Stewart Branch, as faced up for examination but not driven to solid coal, the whole thickness was 59 inches, of which the bottom bench of cannel coal was 17 inches. A greater thickness has been reported near the head of Millers Branch. But at the head of the left prong of Stewart Branch and at a point to the westward Mr. Thurston measured 38 inches of common coal and 18 inches of cannel, and 39 inches and 13, respectively. This bed makes a horizon which has recurring local areas of cannel coal in connection with ordinary soft coal; it extends over a large field in greater or less thickness, with here and there pockets of cannel coal added to its bed section or taking the place of some of its layers, as the case may be; but it has only at wide intervals bodies of cannel which separately may be made the basis of a mining industry.

Where the coal was mined the cannel bench showed (fig. 26, section 180) a thickness of 18 inches overlain by 34 inches and more of bituminous coal. ${ }^{1}$ In the mine inspector's report for $1899^{2}$ it is stated that "there is an almost inexhaustible supply of the Pineville cannel"; and again that "the No. 2 mine is in a vein 50 inches thick, of which 12 inches at the top is cannel." In describing this property the chief engineer of the company says: "This seam is about 4 feet thick and carries a cannel seam from 8 to 24 inches thick" (fig. 26, section 181)..$^{3}$

Chenoa.-On Bear Creek branch of Clear Creek (location 2) is a body of cannel coal that was mined extensively from 1893 to 1899 . The cannel here as usual proved to be in a basin in which the width of workable coal was only 600 feet. This was followed down the dip for about 4,000 feet at constantly increasing cost until 1899, when the burning of the tipple led to the abandonment of the mine. The dip of this basin is steep, being about $8^{\circ}$ for the first 400 or 500 feet and $5^{\circ}$ for the next 400 or 500, beyond which it gradually decreases to $2^{\circ}$ or less. When operations ceased plans were on foot for making a new opening by a slope in order to reach the coal near the present face. This coal shows a total section of over 7 feet in the center of the basin, thinning out to the edges. The upper part is bituminous and the lower part cannel. One section, reported by A. R. Crandall, ${ }^{4}$ gave 34 inches of bituminous coal at the top separated by 1 inch of charcoal from 52 inches of cannel coal at the bottom. The section measured near the ventilating furnace, however, showed the bed much broken up, the cannel appearing in two benches, the upper of 7 inches and the lower of 14 inches, the whole bed having a thickness of 97 inches. As a rule, however, there is here a single block of bituminous coal above a shale parting which

\footnotetext{
${ }^{1}$ Norwood, C. J., Kentucky Inspector of Mines Tenth Ann. Rept., p. 119, 1894.

2 Stone, G. W., Kentucky Inspector of Mines Sixteenth Ann. Rept., pp 112, 140, 1900.

s Norwood, C. J., Kentucky Inspector of Mines Ann. Repts. for 1905, 1906, p. 169, [1907?].

- Ashley, G. H., and Glenn, L. C., op. cit., p. 94.
} 
may resemble cannel at the top or bottom. The thickness of the cannel-coal bench ranges from about 55 inches in the center of the basin to 30 inches at the sides where mining stopped. It may be assumed that this basin, or channel, extends eastward or southeastward through the ridge. (See fig. 26, sections 182, 183, and analysis 32 , p. 21. $)^{1}$

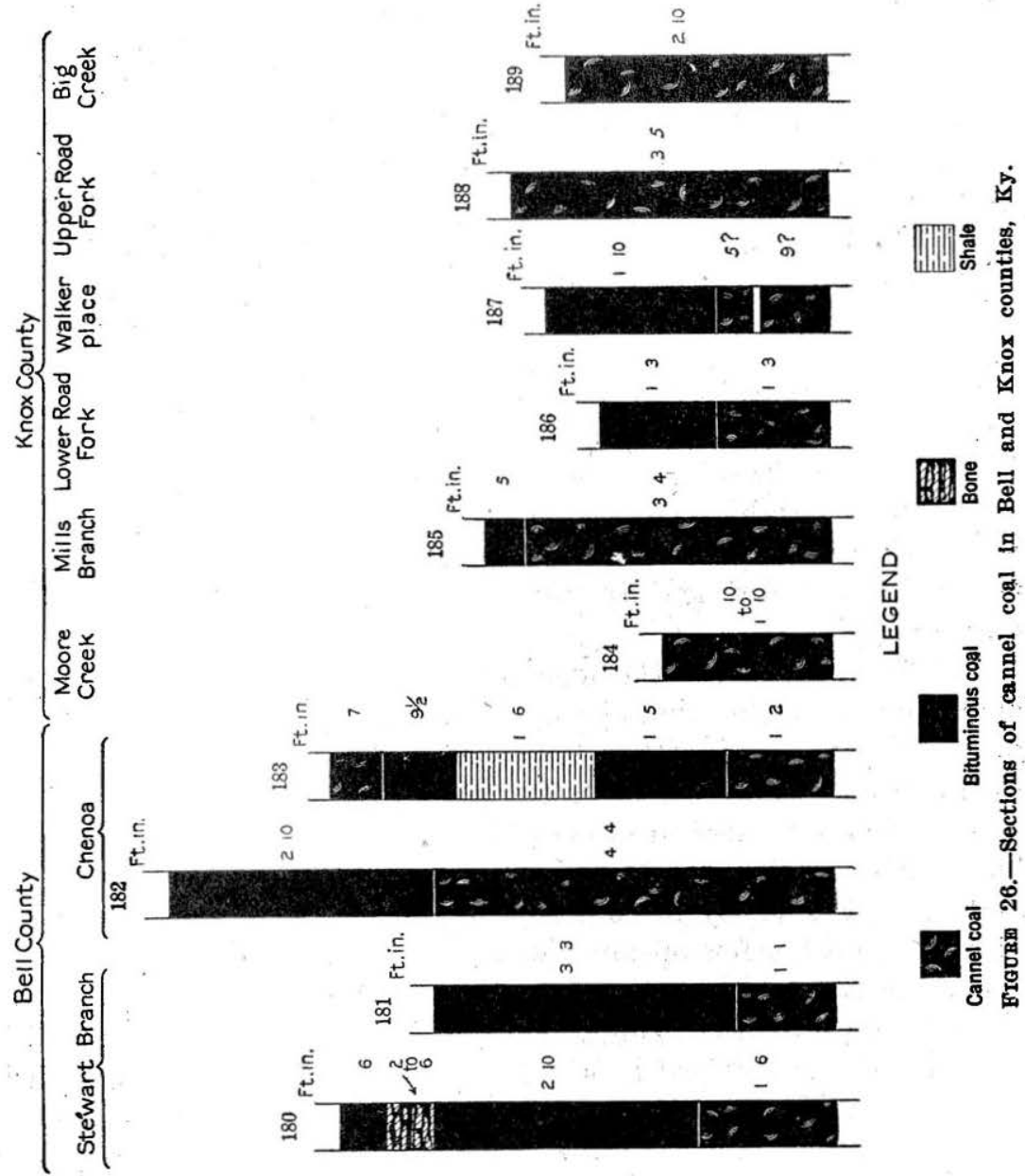

KNOX COUNTY.

Cannel coal in Knox County, so far as described, appears to be confined to the valley of Stinking Creek and to one exposure on Bull Creek. All of the following areas, except the last, are on tributaries of Stinking Creek.

Moore Creek.-On the left fork of Moore Creek (location 6) 10 to 22 inches of cannel (fig. 26, section 184) has been found in a bed

${ }^{1}$ Ashley, G. H., and Glenn, L. C., U. S. Geol. Survey Prof. Paper 49, pp. 94-95, 1906. 
thought to be above the Dean and probably at the horizon of the McGuire coal, which is cannel bearing in Bell County. ${ }^{1}$

Mills Branch.-At the Anderson Mills entry on Mills Branch, 280 feet above the creek (location 4), the cannel bed has a thickness of 45 inches (fig. 26, section 185), including 5 inches at the top, which is partly splint. The coal appears to be limited to a pocket in the ridge between Mills Branch and Dickey Branch to the north. ${ }^{2}$

Lower Road Fork.-The McGuire bed is cannel bearing at the Williamson place at the mouth of Lower Road Fork (locations 2 and 7). The cannel is 15 inches thick overlain by 15 inches of bituminous coal (fig. 26, section 186). At the Walker farm, $1 \frac{1}{2}$ miles up the creek, the cannel carries a 1 -inch clay parting 5 inches from the top and a bituminous bench 22 inches thick (fig. 26, section 187). The coal is here about 400 feet above the creek. This bed has been widely recognized toward the heads of the forks of the main Stinking Creek, though the cannel part of the bed is commonly thin or absent.

Upper Road Fork.-Toward the head of Upper Road Fork (location 3) the McGuire coal attains a workable thickness. Thus at David Price's place, 7 miles above the mouth of the fork, the cannel coal is 41 inches thick (fig. 26, section 188), but from here it thins in every direction. The workable portion is limited to the ridge between the main fork and Spring Branch. An analysis (97) is given on page $24 .^{2}$

Middle Fork.-Near the mouth of Middle Fork, about 650 feet above the creek (location 5), on the J. M. Bingham place 13 inches of cannel coal overlies 24 inches of bituminous coal and underlies 3 inches of bituminous coal. On the Big Creek side of this same ridge and a mile away this bed shows 12 inches of cannel over 24 inches of bituminous coal at the Acy Messers opening. It is readily traced along Big Branch by the outcropping cannel. ${ }^{3}$ On Brown Branch of Middle Fork a few openings have been made to this coal, showing about the same thickness as at the Walker opening (location 5) on the opposite side of the ridge. On the Jeff Hammond Fork of Middle Fork the cannel coal is 6: to 8 inches thick. On Tom and Wash branches of Salt Gum Branch of Middle Fork the cannel is from 9 to 11 inches thick and is overlain by 5 inches of cannel shale.

Big Creek (main branch?).-On Broughton Branch at the B. D. Allen mine (location 1) the cannel bed reaches a maximum of 34 inches (fig. 26, section 189), but decreases in thickness in a short distance. Other cuts in this neighborhood failed to develop pockets of promise. On the Buckeye and Acorn branches of Big Creek, which head against the head of Salt Gum Fork of Middle Fork, the

${ }^{1}$ Crandall, A. R., and Sullivan, G. M., Kentucky Geol. Survey Bull. 14, p. 127, 1912.

2 Idem, p. 125.

Idem, p. 128. 
cannel bed carries 13 inches of cannel. It is 9 inches thick near the Isaac Taylor place, 4 miles from the head in a bed $14 \frac{1}{2}$ inches thick, and 8 inches thick $3 \frac{1}{2}$ miles below the head. ${ }^{1}$

Bull Creek.-On the T. Jones place, 2 miles up Bull Creek of Colon Fork of Goose Creek 15 inches of cannel is reported.2 Near the mouth of Bull Creek (location 8), on the Harpers land, the cannel is 26 inches thick but is very shaly.

\section{CLAY COUN๋TY.}

The bed of cannel coal found on Middle Fork of Stinking Creek in Knox County has beèn opened also on the headwaters of Kentucky River (location 1) in Clay County. ${ }^{3}$

A table of analyses published by Hodge ${ }^{4}$ includes two of cannel coal from Clay County, one of which (analysis 69, p. 22) is described as from J. T. Smith's place on Tom's Branch (cannel 5 inches), and the other (analysis 70, p. 22) from the J. M. Jones place (location 2), Beech Creek, Clay County (cannel 15 inches).

\section{LAUREL COUNTY.}

Cannel coal 4 feet 2 inches thick is reported to have been opened on Cane Creek about $2 \frac{1}{2}$ miles north of the Chris Hale place in Laurel County. At another opening on Indian Camp Branch of Craigs Creek apparently the same bed, coming immediately under the cap rock of the plateau in this area, has been opened and shows 36 inches of cannel overlying 8 inches of sandy shale and coal and 6 inches of bituminous coal.

\section{WHITLEY COUNTY.}

Character of the coal.-Part of Whitley County is underlain by a coal having a peculiar pitted fracture, to which the name bird's-eye is given. The bed, which is now thought to be the same as the Jellicoe, ranges from a rich pure cannel to a semicannel or splint coal and to a black coal. The bird's-eye fracture persists through the several changes, though it does not everywhere persist through the whole thickness of the bed. None of the analyses at hand indicates that any of this coal is a high-volatile cannel, though such cannel may exist in the region. The peculiar fracture is most striking at right angles to the bedding. ${ }^{5}$ As shown on the map (Pl. VII, p. 82)

1 Crandall, A. R., and Sullivan, G. M., Kentucky Geol. Survey Bull. 14, p. 127, 1912.

2 Hodge, J. M., Preliminary report on the geology of the lower North Fork, Middle and South forks, Kentucky River, p. 74, Kentucky Geol. Survey, 1887.

${ }^{3}$ Crandall, A. R., and Sullivan, G. M., op. clt., p. 128.

sodge, J. M., op. cit. p. 96.

5 Crandall, A. R., Report on the geology of Whitley County, etc., plate opposite p. 37, Kentucky Geol. Survey, 1889 [date of map]. 
the cannel and semicannel condition of this bed centers mainly in the Patterson Creek region but is found also on Big and Little Caney and Mud and Polar creeks. Though not a rich coal for the manufacture of oil, it is free burning and is adequate for many of the uses of cannel.

Patterson Creek.-Near the head of Patterson Creek (fig. 27, section 190) 52 inches of block coal shows at the Polly mine (locations 1, 3, 5, and 6), of which 31 at the base is bird's-eye. On Bennett Fork of Patterson Creek (location 3, section 193) the bed is from 48 to 50 inches thick and is a semicannel. On the Lawson tract the bed shows 11 inches of bird's-eye at the base, then 13 inches of
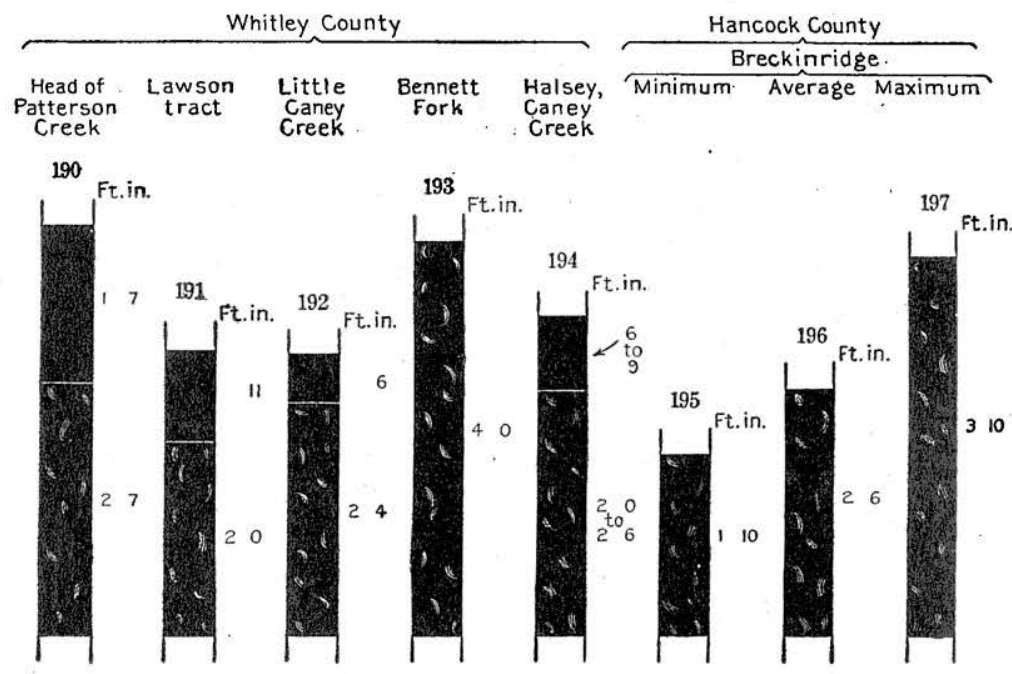

LEGEND

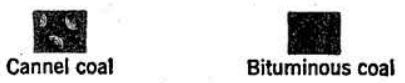

Figure 27.-Sections of cannel coal in Whitley and Hancock counties, Ky.

cannel, then 11 inches $\cdot$ of bituminous coal ${ }^{1}$ (fig. 27 , section 191, and analyses 134,136, p. 25). This bed is a cannel coal on Mud Creek also (locality 4 ).

Little Caney.-At the head of Little Caney (location 2) the bed carries 28 inches of cannel and 6 inches of bituminous coal. ${ }^{2}$ (See fig. 27 , section 192 , and analysis 137, p. 25 .)

Halsey.-At Halsey on Caney Creek (location 7) the Jellicoe and Birdseye Coal Co had, in 1893, made a number of openings on the bird's-eye coal. At the Halsey mine the coal (analysis 138, p. 25) con-

\footnotetext{
${ }^{1}$ Hendrie, Charles, Kentucky Inspector of Mines Tenth Ann. Rept., p. 147, 1894.

2 Crandall, A. R., op. cit., p. 38. Miller, A. M., Kentucky Geol. Survey Bull. 12, p. 69, 1910.
} 
tained (fig. 27, section 194) 2 feet or a little more of bird's-eye and semicannel, and 6 to 9 inches of bituminous coal. ${ }^{1}$

\section{HANCOCK COUNTY.}

The famous Breckinridge cannel coal, probably the best known of the Kentucky cannels and the oftenest mentioned of American cannels, lies in Hancock County just over the boundary from Breckinridge County.

The extent of the cannel coal is not known. Mining was carried on in a ridge between Tarr Fork and Panther Creek, the mines being on the Tarr Fork side. It has been generally assumed that the cannel-coal field is exhausted. Norwood, ${ }^{2}$ after examining the area in 1875 , concluded that a large body of cannel coal, possibly 4,000 acres, still remained. Mining was resumed and it is possible that when it finally ceased all the coal at that time minable had been removed. The cannel bed lies at the base of the coal-bearing rocks and was from 22 to 38 inches thick, locally reaching 46 inches. The average is given as about $2 \frac{1}{2}$ feet or a little over. (See fig. 27, sections 195-197, and analyses $75-80$, p. 23.)

Miscellaneous localities.-In other parts of the western field of Kentucky coals Nos. 1, 5, and 11 locally carry workable thicknesses of cannel. Usually these are mined along with the bituminous coal, which they accompany, no attempt being made to find separate markets for the cannel portion of the bed. Near Dekoven coal No. 11 carries 14 to 15 inches of cannel overlying a small amount of bituminous coal. Cannel has been noted associated with this bed in Muhlenberg and Union counties, though it is usually of poor quality. Coal No. 5 also contains cannel at Dekoven, where a 25inch bench lies between two 6-inch benches of'bituminous.

\section{TENNESSEE.}

In Tennessee cannel coal is mined only south of Jellico, about 2 miles from Newcomb, in Campbell County; where for some years it has been mined by the Jellico Cannel Coal Co. The bed has an average thickness of 30 to 36 inches and lies about 1,800 feet above sea level. Benches of cannel coal of small lateral extent occur at Bon Air and Whitwell and at a few other places in the State.

\footnotetext{
${ }_{1}^{1}$ Norwood, C. J., Kentucky Inspector of Mines Tenth Ann. Rept., pp. 128, 177, 1894.

${ }^{2}$ Norwood, C. J., Report of a reconnaissance of a part of the Breckinridge cannel-coal district: Kentucky Geol. Survey Repts. Progress, vol. 4, new ser., p. 352, 1878; Western coal fleld, p. 206, Kentucky Geol. Survey, 1884.
}

$$
87775^{\circ}-18-\text { Bull. } 659-8
$$


ALABAMA.

In the Cahaba coal field of Alabama, west of Montevallo and northwest of Briarfield, an area of overturned rocks includes several coal beds. ${ }^{1}$ One of these, "the cannel seam," occurs on Little Mayberry Creek and is described by Squire as 3 to $3 \frac{1}{2}$ feet thick and partly bony. Squire adds that the bed is overturned and dips $56^{\circ}$. In the same chapter Squire gives an analysis of the "B" bed, showing 56.1 per cent of volatile matter, 37.4 per cent of fixed carbon, and 3.1 per cent of ash, but does not make clear whether this is the "cannel seam." Its resemblance to a cannel-coal analysis and the contrast with other analyses of coals in that area suggest that it may be.

\section{WA.}

Cannel coal is found in Iowa only near Fort Dodge and in a few other localities. The bed in the vicinity of Fort Dodge, which occurs near the base of the coal-bearing rocks, extends over a moderately large area along the river and appears to be rather more regular than the bituminous beds just above it, some of which are very pockety, varying several feet in thickness in less than 100 yards. North of Fort Dodge the cannel seam is 20 to 30 inches thick. Three mines have recently operated near Kalo. At the Johnson mine the cannel occurs as a 16-inch bed separated by 3 inches of shale over an underlying bench of bituminous coal 22 inches thick; at the Irvine mine at Kalo the coal is 28 inches to 3 feet thick; at the Craig \& Dawson mine the cannel is about $3 \frac{1}{2}$ feet thick. ${ }^{2}$ The coal is overlain by shale and underlain by shale or clay at all of these places. On Holaday Creek, near Coalville, the seam consists of 4 to 9 inches of cannel above 1 to 3 feet of bituminous coal. ${ }^{3}$

At the Tann mine, in Guthrie County, in the NE. $\frac{1}{4}$ SE. $\frac{1}{4}$ sec. 22 , T. $79 \mathrm{~N} .$, R. $30 \mathrm{~W},,^{4}$ there is 22 inches of cannel which is just on the border line between cannel and bituminous, showing about equal percentages of volatile matter and fixed carbon or a fuel ratio very close to 1 . The ash ranges from 15 to 36 per cent in the analyses at hand and the sulphur from 7 to 11 per cent. The high sulphur content would be sufficient to prevent the use of this coal for some purposes.

\section{MISSOURI.}

OCCURRENCE OF THE COAL.

In a broad area southeast of the main coal field of Missouri there are pockets of "Coal Measure" rocks, many of which contain beds

\footnotetext{
${ }^{1}$ Squire, Joseph, Report on the Cahaba coal fleld, pp. 97-100, Alabama Geol. Survey, 1890.

2 Keyes, C. R., Coal deposits of Iowa : Iowa Geol. Survey, vol, 2, pp. 204, 205, 1894.

s Idem, pp. 40, 42, 43.

1 Idem, p. 247.
} 


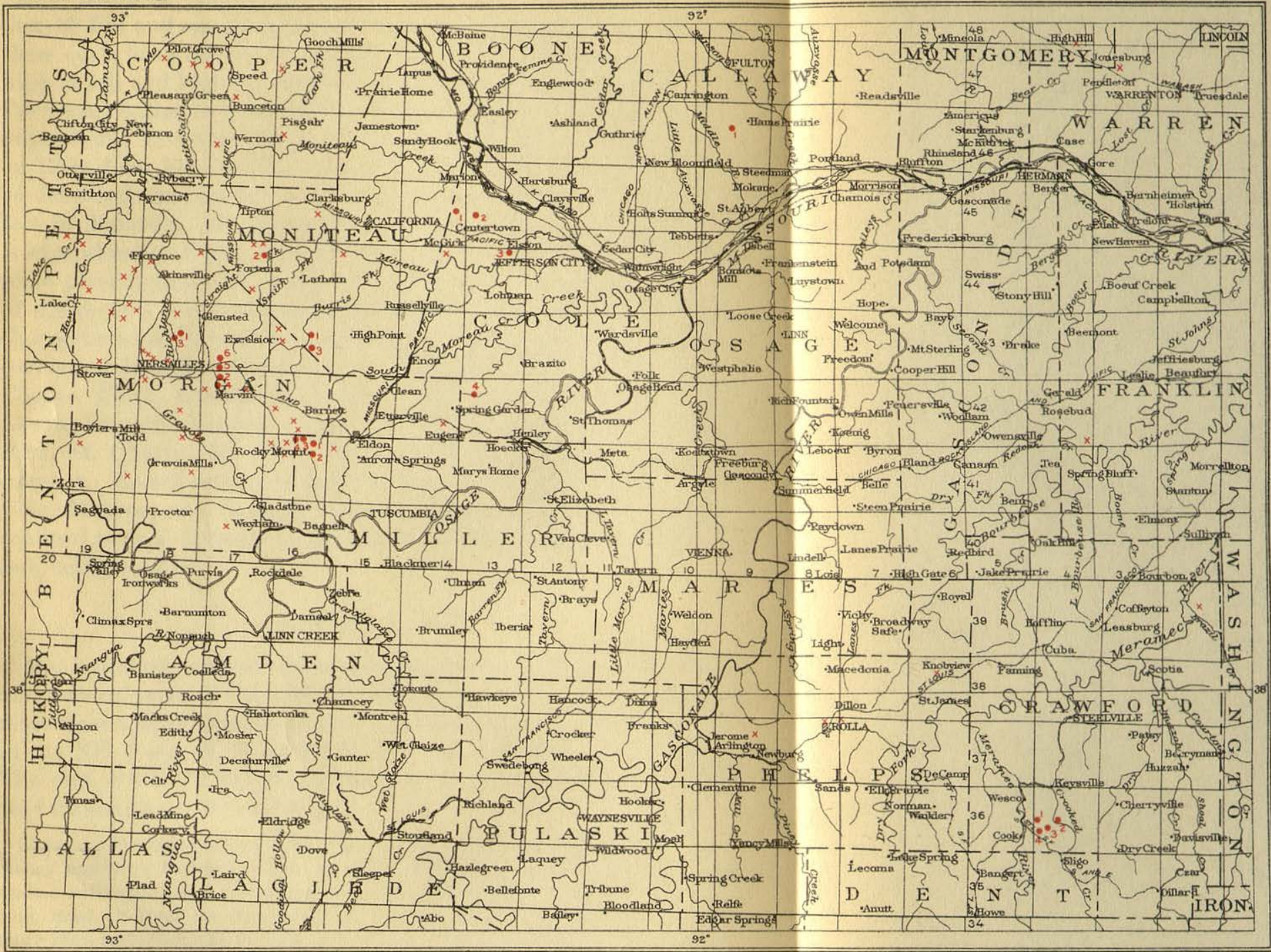

Base from U.S. Geological Survey map of Missouri. Compiled by A. F. Hassan

$$
+0_{2}^{\circ} \bullet_{3}
$$

Deposits referred to in text (Separate series of numbers for each county)
MAP OF PART OF MISSOURI SHOWING LOCATION OF CANNEL COAL DEPOSITS

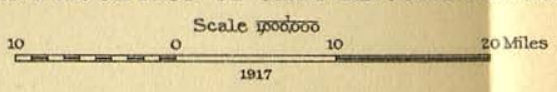

Basins that contain coal-bearing rocks (possibly cannel coal); from Hinds's "Coal deposits of Missouri" 

of cannel coal. (See PI. VIII.) Most of these pockets appear to be in old sink holes, dissolved out of the limestones, though some are in narrow valleys. Such pockets occur in 35 counties. The coal in many places is remarkably thick, some deposits measuring more than 50 feet and one shaft having penetrated nearly 90 feet. Though these coals have not been analyzed, they are described as commonly high in ash and high in volatile matter. Many of these pockets, like the cannel basins in Kentucky and elsewhere, have been the basis for unprofitable investment and probably more money has been spent on them than has been made out of them. Most of the basins to be described are circular or oval and not more than a few hundred feet in diameter. An aggregate of 500,000 tons in a single pocket is exceptionally large, most of them being very much smaller. In some places seams and bands of lead or zinc ore add to the value of the pocket, and in others small deposits of flint clay and plastic clay occur with the coal and may be mined with it at a profit. Cannel coal occurs in such pockets in Benton, Boone, Callaway, Cedar, Cole, Cooper, Clark, Crawford, Camden, Dade, Douglas, Dent, Jasper, Lewis, Lincoln, Marion; Miller, Moniteau, Montgomery, Morgan, Pike, St. Charles, St. Clair, St. Louis, Saline, Warren, and other counties. Recent mining appears to have been confined to Moniteau, Cole, Monroe, and Morgan counties. Further description will be confined to such deposits as have been worked in recent years or are now being worked.

\section{CALTAWAY COUNTY.}

Many pockets, some of remarkable thickness, occur in the southern and eastern parts of Callaway County, but not one of them contains more than a small amount of coal. One of them, near Hams Prairie, in the NE. $\frac{1}{4}$ sec. 16, T. 46 N., R. 9 W., is worked by W. C. Weeks. The coal is 5 to 12 feet thick, the lower part cannel and the upper part bituminous. Hinds ${ }^{1}$ says:

Callaway County has long been noted for its pockets of thick coal, and much money has been wasted by those who have attempted to mine them on a large scale. Although many are remarkably thick, containing as much as 80 feet of coal, most of them are very small in lateral dimensions and do not contain more than sufficient coal for purely local use. These pockets occur in all parts of the county, but are exposed only outside the area covered by the main body of the Pennsylvanian ("Coal Measures"). They are especially well known in the rough country near the Missouri River, where many were mined during early days to supply fuel for the boats then so numerous on the river. Many old workings may be observed near Hibernia and Mokane, and exaggerated statements as to the amounts of coal in those districts are still current.

\footnotetext{
${ }^{1}$ Hinds, Henry, The coal deposits of Missouri: Missouri Bur. Geology and Mines, 2d ser., vol. 11, p. 114 [1912].
} 
COLE COUNTY.

Many coal pockets have been found in Cole County, especially near Centertown and Elston, and some mining has been done there. Probably, however, more money has been spent in prospecting for coal in this county than has been made by mining. Many of the pockets were described by Broadhead, ${ }^{1}$ chiefly those north of Centertown. The most recent mining at this point on cannel coal is said to have been on the Leonard farm, 2 miles north of Centertown (location $1^{2}$ ), where a pocket 200 feet in diameter, carrying 14 feet of cannel above 4 feet of bituminous coal, was worked for three years from a 30 -foot shaft. On the Bryant place 2 miles northeast of Centertown (location 2) are 20 to 30 feet of cannel, which were formerly stripped. ${ }^{3}$ Cannel coal was being mined in 1911, if not at present, at the S. \& A. Bandelier mine, $1 \frac{1}{2}$ miles due south of Elston (location 3). The coal is in a pocket 250 feet wide from east to west and somewhat longer from north to south. ${ }^{3}$

Section at the S. \& A. Bandelier coal pocket, Cole County, Mo.

$\begin{array}{lr}\text { Clay } & \text { Feet. } \\ \text { Bone } & 20 \\ \text { Coal, bituminous } & \\ \text { Shale, "slaty "-- } & 6 \\ \text { Cannel coal, bottom not reached. } & \end{array}$

The coal lies nearly flat in the center of the deposit, but the bedding turns up to $80^{\circ}$ at the edges as though held back in the settling of the material of the pocket at some time subsequent to its laying down. Between the coal and rocks in the pocket and the outside walls a layer of clay, like that commonly found in fault planes, made the pocket a natural reservoir, so that when the mine was opened 6,000 barrels of water had to be pumped out, after which no further difficulty of that kind was encountered. The cannel is very clean, with a little pyrite and zinc blende near the outer edge of the pocket. It splits easily with the bedding, but has no other regular fracture. Eighty-six feet of coal under 12 feet of soil is reported, as shown by a drilling on the Stehlein farm not far from this mine.

Near Hickory Hill (location 4) the Dustless Coal Co. opened a mine after constructing a 7-mile spur from Henley. The prospect shaft is reported to have cut 82 feet 9 inches of cannel coal, bearing galena and zinc blende. When visited by Hinds ${ }^{4}$ in 1911, 8 feet of cannel were exposed in a pit at the shaft mouth.

\footnotetext{
${ }^{1}$ Broadhead, G. C., Cole County : Missourl Geol. Survey Rept. for 1873-74, pp. 322-338, 1874.

${ }^{2}$ Locations in Missouri are numbered by counties. (See Pl. IX.)

${ }^{3}$ Hinds, Henry, The coal deposits of Missouri: Missouri Bur. Geology and Mines, 2d ser., vol. 11, p. 158 [1912].

Idem, p. 159.
} 
COOPER COUNTY.

Nearly all of the townships of Cooper County contain cannel and bituminous coal in pockets, in some of which the coal is 30 or more feet thick.

\section{CRAWFORD COUNTY.}

Many small pockets of coal occur in Crawford County between Sligo and Keysville in T. 36 N., R. 4 W. There are pockets in the west half of sec. 19 (location 1) reported by Winslow as 40 feet thick; in the NE. $\frac{1}{4}$ SE. $\frac{1}{4}$ sec. 21 (location 2); in the NE. $\frac{1}{4}$ NW. $\frac{1}{4}$ sec. 29 (location 3 ); and in the NE. $\frac{1}{4}$ sec. 30 (location 4 ). None of them are believed to be of much value.

JASPER COUNTY.

Smith and Siebenthal ${ }^{1}$ report: "In many of the hollows and sink holes eroded in the surface of the Boone and filled by Cherokee, coal pockets were found, the thickness of coal accumulated being in places very great. The coal is commonly cannel." Most of the described deposits are only a few feet in diameter and 2 to 8 feet thick. $^{2}$

LINCOLN COUNTY.

Coal pockets of great thickness occur in Lincoln County. Several of them on the headwaters of Coon Creek have attracted much attention in the past and have been mined a little. ${ }^{3}$

\section{MULLẸER COUNTY.}

Several pockets of cannel coal have been encountered in wells in Miller County, but none has yet been mined. In T. 41 N., R. 16 W., 3 feet of cannel at a depth of 19 feet is reported from the SE. $\frac{1}{4}$ sec. 2 (location 1) ; 3 feet in the well at the schoolhouse in the center of sec. 11. (location 2); 12 to 14 feet at a depth of 8 feet on the Joseph Garden place in the south center of the NW. $\frac{1}{4}$ NE. $\frac{1}{4}$ sec. 3 (location 3 ) ; and a bed at 48 feet in the well near the center of sec. 11. In the same township cannel coal is exposed in the stream banks in the SW. $\frac{1}{4}$ NW. $\frac{1}{4}$ sec. 3 (location 4) and in the bed of a small stream in the center of the W. $\frac{1}{2} \mathrm{SW} . \frac{1}{4}$ sec. 2 , where a 40 -foot shaft is all in cannel coal except $1 \frac{1}{2}$ feet of carbonaceous shale. ${ }^{4}$

1 Smith, W. S. T., and Siebenthal, C. E., U. S. Geol. Survey Geol. Atlas, Joplin district folio (No. 148), pp. 19-20, 1907.

2 Hinds, Henry, Missouri Bur. Geology and Mines, 2d ser., vol. 11, p. 215 [1912].

8 Idem, p. 253.

4 Ball, S. H., and Smith, A. F., Geology of Miller County : Missouri Bur. Geology and Mines, 2d ser., vol. 1, p. 103, 1903. 


\section{MONITEAU COUNTY.}

All of the coal in Moniteau County occurs in pockets, of which at least three are being mined.

The Monarch Coal \& Mining Co. is mining cannel in sec. 15, T. 43 N., R. $16 \mathrm{~W}$. (location 1), by stripping and by drifts. The stripped pit shows 30 feet of cannel coal, overlain by 5 feet of poor bituminous coal. A 90-foot shaft at the east end of the open cut is in cannel, and a tunnel driven 140 feet south from the foot of the shaft is reported to be all in cannel. In the open cut the coal dips $45^{\circ}$, but at the end of the tunnel or drift it lies flat. The pocket is about 400 feet long by 150 to 200 feet wide, and the cannel is estimated to be 45 feet thick where the dips are absent. The total contents of this pocket do not appear to be over 75,000 tons.

At the Newkirk mine, in the NW. $\frac{1}{4}$ SE. $\frac{1}{4}$ sec. 12, T. 44 N., R. $17 \mathrm{~W}$. (location 2), the shaft is 110 feet deep. Coal was struck at 45 feet and continued for 65 feet to the bottom of the shaft. Drifts have been cut to the north and the south, and from them 30 feet of coal has been mined. The coal pitches toward the center from all sides and is well jointed and slickensided and of fair quality, though high in ash. The deposit is estimated to be about 285 feet long by 100 feet wide.

Two shafts have been sunk by C. P. Keller in the NE. $\frac{1}{4}$ sec. 22 , T. 43 N., R. 16 W. (location 3). One of them struck 6 feet of bituminous coal at 20 feet and $7 \frac{1}{2}$ feet of (cannel?) coal 24 feet lower.

The Rohrback \& Rowlin Mining Co. sunk a 50-foot shaft in the S. $\frac{1}{2}$ SE. $\frac{1}{4}$ sec. 23 , T. 45 N., R. 15 W., disclosing 10 to 15 feet of cannel coal over 10 feet of poor bituminous coal and under 10 feet of bituminous shale. The coal is said to slack badly and to have a high percentage of ash. The pocket measured about 125 by 80 feet. $^{1}$

\section{MORGAN COUNTY.}

The pockets in Morgan County have been worked to some extent and have figured in a number of real estate deals involving considerable areas of land. The Stover mine shows an interesting example of a pocket of bituminous coal 70 feet thick. The Hubbard \& Moore mine in the SW. $\frac{1}{4}$ SW. $\frac{1}{4}$ sec. 22 , T. 43 N., R. 18 W. (location 1), is working a very irregular deposit about 20 feet thick, of which the upper 15 feet is cannel and the lower 5 feet bituminous coal. Black shale occurs both above and below the coal. Where obtained the coal dips $32^{\circ}$ to $33^{\circ}$ but flattens out in a short distance. In the NW. $\frac{1}{4}$ SE. $\frac{1}{4}$ sec. 5, T. 42 N., R. 17 W. (location 2), is a 12 to 15 foot bed

1 Van Horn, F. B., The geology of Moniteau County : Missouri Bur. Geology and Mines, 2d ser., vol. 3, pp. 65-68, 78-79, 1905. Hinds, Henry, Missouri Bur. Geology and Mines, 2d ser., vol. 11, pp. 307-308 [1912]. 
of coal, of which the upper half, or a little more, is cannel. Mining has been carried on in a small way at many places in the county. ${ }^{1}$ In a pocket being worked for coal and clay by the Ouachita Coal \& Clay Products Co. in the SW. $\frac{1}{4}$ SW. $\frac{1}{4}$ sec. 22, T. 43 N., R. 18 W. (location 3), there is exposed 15 feet of alternating layers of bituminous and cannel coal. Pockets of cannel that have been worked out are $1 \frac{1}{2}$ miles east of Versailles at the Martin mine (location 4) in the SW. $\frac{1}{4}$ SE. $\frac{1}{4}$ sec. 5, T. 42 N., R. 17 W.; at the McClure bank (location 5) a mile north of Martins; and at the Price bank (location 6) half a mile north of the McClure bank. ${ }^{2}$

SALINE COUNTY.

A pocket of bituminous and cannel coal 22 feet thick was formerly worked at Napton, Säline County.

\section{ARRANSAS.}

Extending northwestward from Camden, Ouachita County, Ark., is a small area of typical brown subcannel, which has been tested for oil and gas production with very favorable results (pp. 38, 47). The coal bed has been traced from about 2 miles northwest of Camden for 13 miles to the northwest and has been opened and mined in a small way at a number of places. Among these openings, in which the coal ranges from 3 to 6 feet in thickness, are the following: Brown mines, east side of sec. 12 , T. 13 S., R. 18 W., coal 3 to ' $3 \frac{1}{2}$ feet; Williams mine, north side of sec. 11, T. 13 S., R. 18 W., coal $3 \frac{1}{2}$ feet; Demsey mine, NE. $\frac{1}{4}$ SW. $\frac{1}{4}$ sec. 25 , T. 12 S., R. 18 W., coal 3 feet; two drifts near center of sec. 14 , T. 12 S., R. 18 W., to which a 3-mile railroad spur was built, coal reported 5 to 6 feet; mine in NE. $\frac{1}{4}$ sec. 12, T. 12 S., R. 18 W., opened before 1860, coal 3 feet 6 inches to 6 feet; mines in secs. 7 and 19, T. 12 S., R. 17 W., coal 3 to $3 \frac{1}{2}$ feet; Bratt shaft, sec. 2, T. 13 S., R. 18 W., 3 feet of coal at 40 feet. $^{3}$

Physically the Camden coal, as it comes from the mine, ${ }^{4}$ is

brownish black and compact and has a generally uniform even texture and structure. Occasionally fragments of lignite with clearly marked woody structure may be seen. It has an uneven conchoidal fracture. It is soft but not friable, that is, it may be easily mined with the pick and may be cut with a knife as readily as compact dry clay, but will not crumble between the fingers. When cut or scratched with a knife it shows a shiny or oily streak. Upon being exposed to dry air the coal contracts and cracks both along the bedding and at right angles to it so that fragments may be broken by the hand, but the mass does not fall to pieces. The coal is then blacker and harder than when fresh

\footnotetext{
1 Marbut, C. F., The geology of Morgan County : Missouri Bur. Geology and'Mines, 2d ser., vol. 7, pp. 79-86 [1908].

${ }^{2}$ Hinds, Henry, Missouri Bur. Geology and Mines, 2d ser., vol. 11, p. 318 [1912].

3 Tauf, J. A., Preliminary report on the Camden coal field of southwestern Arkansas: U. S. Geol. Survey Twenty-first Ann. Rept., pt. 2, pp. 323-324, 1900.

${ }^{4}$ Idem, p. 325.
} 
and the streak or powder is more nearly black. On being exposed for a short time to the repeated action of rain, dew, and snow, however, it will disintegrate into small particles.

From this description the coal is evidently of lignite rank, but so far as tested it appears to give a higher candlepower gas than other lignites. Chemically, as shown by the analyses (Nos. 13-18, p. 20), it contains from 32 to 38 per cent of water when fresh. In dry air the moisture will be reduced to 9 to 11 per cent, but this will be reincreased to 20 to $22 \frac{1}{2}$ per cent if the coal is submitted to saturated air. The volatile matter in the fresh coal is 32 to 36 per cent and 44 to 46 per cent in the air-dried coal; and the fixed carbon in the fresh coal is 17 to 23 per cent and 29 to 33 per cent in the air-dried coal. The ash remains from 7.5 to 11 per cent in the fresh coal and the sulphur 0.5 per cent or less in the fresh material.

This coal was tested by the Pittsburgh Testing Laboratory (Ltd.). The average result of 10 tests, at a temperature of $1,800^{\circ}$ to $2,000^{\circ}$ F. was a yield of 11,386 cubic feet of 22.3 candlepower gas. How this compares with other coals is shown in the table on pages 37-38.

David White, ${ }^{1}$ who visited the field, describes as follows the two stills that were in operation:

The commercial untilization of the lignite from the Camden field is somewhat unique, for although it is employed to a limited extent for local steam-boiler fuel and on the locomotives of the branch railroads coming to the sawmills and mines about Lester, the principal use of the coal appears to be for its distillation products. The best massive brown lignite, essentially "amorphous" and free from bedding, is that most sought for distillation. Such lignite is said to yield as high as 38 gallons of oil per ton, though the average oil production from the lignite as it is mined and distilled approximates 25 gallons per ton. Occasionally lignite which yields as low as 10 gallons per ton is dug at some of the mines in the field. At the time of the field examinations of the fuel by the writer the methods of distillation were still in an experimental stage. A small distillery or "oil mill" was in operation at the town of Camden and another one near Lester. The former had seven horizontal retorts, whereas the latter had only five in an inclined position and farther above the grate. The Lester mill had a capacity of two tons in 24 hours. For three or four hours the lignite in the retort was subjected to a temperature of about $400^{\circ}$ F., after which it was advanced for a time to a temperature of about $700^{\circ}$, and finally to $1,200^{\circ}$ or $1,300^{\circ} \mathrm{F}$., eight or nine hours being required for the complete run. Some of the oil is given off at a temperature of about $400^{\circ} \mathrm{F}$., different oils being yielded at different temperatures, those distilling later at the higher temperatures being regarded as best. Likewise, the higher temperatures appear to yield by-products more tarlike and differing in other respects. The brown canneloid is said to yield a lighter-colored oil.

The distillates are said to be used in the rubber industry, in soap making, in paints, and in various proprietary preparations. The residual cinder can hardly be called coke, although often on withdrawing the charge there appears to be a recondensation at the back end of the retort which results in small pieces of completely fused coke, silvery in luster and stalactytic in sculpture,

${ }^{1}$ White. David, and Thiessen, Relnhardt, Bur. Mines Bull. 38, p. 18, 1913. 
though spongy and friable." The higher-grade carbon or cinder derived from the more typical canneloid lignite, after having been ground at the mill, has been shipped to one of the eastern cities, where it was experimentally tried in the manufacture of paint. The small pieces of wood and stem are occasionally found with structure preserved as charcoal among the lumps of lignitic cinder.

TEXAS. ${ }^{1}$

Probably the largest deposit of cannel coal in the United States is in Webb County, Tex., a few miles above Laredo, near the Rio Grande. The coal occurs in Eocene rocks, apparently in beds such as commonly contain soft brown friable lignites, but it is a hard, lustrous, black coal, the beds yielding 75 per cent or more of lump coal by ordinary methods of mining. The coal stands shipping and storing like an ordinary bituminous coal. It differs physically from typical cannel coal in having a brighter luster, in being less massive, and in breaking down under the weather more readily than the Carboniferous cannels, although possibly not more readily than the average bituminous coal. Of the two beds now mined, the lower is more like cannel. In the mine the coal shows one prominent cleavage (N. $30^{\circ}$ E.) closely spaced.

There are two principal beds, about 90 feet apart, and several minor beds, all of the same general character except as the percentage of ash makes some of them bony coals. The upper or Santo Tomas bed has been traced in workable thickness 25 miles or more along the river front. It is 24 to 34 inches thick, this measurement including commonly 2 to 4 inches of bone or shale in the middle, and is underlain by 2 to 14 inches of bone. The lower or San Pedro bed is 22 to 24 inches thick at Dolores, is thin or absent at Santo Tomas, and is reported to be 4 feet thick at the mouth of Llave Creek. Both coals have poor roofs, commonly of clay, and clay floors, inclined to creep, drawbacks that add materially to the cost of mining.

Three mines are now in operation, the Santo Tomas, of the Santo Tomas Coal Co., and the Darwin and Dolores mines of the Cannel Coal Co. These mines are at towns bearing the names of the mines, 23 to 26 miles above Laredo, with which they are connected by the Rio Grande \& Eagle Pass Railway.

The upper coal crops out above the bottoms of the Rio Grande for many miles up the river from Dolores. The beds dip about $2^{\circ}$ NE. This dip carries the coal beds to a depth of several hundred feet under the high bluff that stands a short distance back from the river. One fault of 3 to 4 feet throw breaks the upper bed at the Dolores mines but does not break the lower bed. At the'Santo Tomas

\footnotetext{
1 This section was rewritten Aug. 16, 1917, and inserted in page proof after the author had returned from the Laredo coal fleld, which he studied in detall. This fleld will be described more fully in a forthcoming report of the United States Geological Survey.
} 
mine there are areas where the coal is much broken by fault slips, the thickness of the bed commonly changing abruptly on the two sides of these breaks. These slips, taken in connection with the abundant slickensides in the roof clay, have led the writer to infer that this area has been subject to slight earth pressure and movement, and that because of the large proportion of clay in the section, this pressure, instead of being taken up by massive beds of sandstone, as it commonly is in Carboniferous rocks, was resisted mainly by the coal beds, which were thus raised to the rank of bituminous coals. The dry atmosphere of the region may have reduced the content of moisture in the coal, which is rather dry. Ten recent analyses of the Santo Tomas coal, made in connection with its purchase by the Government for use at Fort MacIntosh, show that it contains 4.45 per cent of moisture as received, and that the dry coal contains 42.5 per cent of volatile matter, 36.8 per cent of fixed carbon, 20.58 per cent of ash, and 2.87 per cent of sulphur, and has a heat value of 10,889 British thermal units as received, or 14,349 British thermal units moisture and ash free.

Tests of this coal for its content of oil gave 52.2 gallons per ton, or 20.2 per cent by weight, with a specific gravity of 0.938 at $60^{\circ} \mathrm{F}$. This area would therefore seem to be a favorable place for establishing a distillation plant, because of the large quantity of coal already found. The coal is now used on seven railroads-the Artesian Belt; San Antonio, Uvalde \& Gulf; Rio Grande \& Eagle Pass; International \& Great Northern; Abilene \& Southern; Coahuila and Zacatecas; and Mexican Government lines. It is shipped to Austin, San Antonio, Corpus Christi, and other places as a domestic fuel and is the principal steam coal of the surrounding region.

UTAH.

A bed of black subcannel (?) coal of subbituminous (?) rank, opened in the valley of North Fork of Virgin River in the Colob coal field at the Cannel King prospect, may be described as typical. The bed, whose extent is not known, contains 5 feet 6 inches of cannel overlain by 2 feet 6 inches of bituminous coal. The opening is in sec. 26 , T. 39 S., R. 9 W. ${ }^{1}$ The associated coal here is subbituminous, and the cannel has a slightly earthy appearance; otherwise it is a typical cannel coal in appearance and characteristics. ${ }^{2}$ The analysis likewise indicates a typical cannel coal: The upper 2 feet carry 44.9 per cent of volatile matter, 28 per cent of fixed carbon, and 14.3 per cent of ash; and the lower $3 \frac{1}{2}$ feet carry 46.9 per cent of volatile matter, 22.4 per cent of fixed carbon, and 23.2 per cent of ash.

\footnotetext{
1 Richardson, G. B., The Harmony, Colob, and Kanab coal fields, southern Utah: U. S. Geol. Survey Bull. 341, p. 394, 1900.

${ }^{2}$ White, David, and Thiessen, Reinhardt, Bur. Mines Bull. 38, p. 244-245, 1913.
} 


\section{N D E X.}

A.

Abbott Creek, Ky., cannel coal on-.

Alabama, cannel coal in canñel coal in, production of

Allegheny County, Pa., cannel coal in

Ammoniacal liquor, derivatives from.

Analyses of cannel coals

cannel coal in, analyses of -119-121 gas from

Armstrong County, Pa., cannel coals in -

cannel coals in, analyses of distillation tests of

Aromatic hydrocarbons, not formed at low temperatures

Ash, analyses of percentage of

B.

Barbour County, w. Va., cannel coal in - W.

Barrett Creek, W. Va., cannel coal on

Baskerville, Charles, cited_-_-_- 42-43, 44

Beaver County, Pa., cannel coals in - 32-33,

cannel coals in, analyses of _-_- $\quad 27$ distillation tests of _..._... 46 distillation products of

Bedding, absence of, in cannel coal. Beech Fork, Ky., cannel coal on_-_ 102

Bell County, Ky., cannel coals in... 34, cannel coals in, analyses of - 21

Benzene, production of

Benzol, production of

Big Creek, Ky., cannel coal on -- 110-111

Big Ugly Creek, W. Va., cannel coal

“Bird's-eye" cannel coal, luster of structure of, plate showing -

Bituminous coal, comparison of, with cannel coal

distillation test o 9-10,15-17

quantity and quality of gas from

Block structure of cannel coal, plate showing

Boghead, Scotland, coal from, analyses of

Boghead, Ky., cannel coal near.

Boghead coal, classification of 84-86

Boone County, w. Va., cannel coals in

cannel coals in, analyses of

6

Can

$\begin{array}{lr}\text { Bopp, C. R., distillation tests by--- } & \text { Page. } \\ \text { Bostonia, Pa., deposits at.-- } & 46 \\ \text { Braxton County, W. Va., cannel coal } \\ \text { in }\end{array}$ in -

cannel coals in, analyses of -.-- 21-22 distillation tests of

Breckenridge, Ky., distilling of oil at -

Brounland, W. Va., cannel coal near- $\quad 77$

Bruin Creeek, Ky., cannel coal on_-_ $\quad 87$

Brushy Fork, Ky., cannel coal on--- 93

Bull Creek, Ky., cannel coal on_--- 111

Bureau of Mines, distillation experiments by

Butler County, Pa., cannel coal in -- 62

By-products, production of --_-_-_-- 44-49

\section{c.}

Callaway County, Mo., cannel coal .

in. coal, analyses of $\quad \begin{array}{rr}115 \\ \text { rk. }\end{array}$

character of -._-_._- 119-120

distillation of - - 120-121

distillation products from_-_-_ 47

Camp Branch, Ky., cannel coal on -- 102

Campbell County, Tenn., cannel coal in

cannel coal from, analysis of _- $\quad 27$

Cannel City, Ky., cannel coal near-- 91-93

Canneloid coal, classification of -.-- 10-11 definition of

Cannelton, Pa., cannel coal at___- 32-33,

Cannelton, w. Va., cannel coal at $50,62-63$

Carter County, W. Va., cannel coals in -

cannel coals in, analyses of --- $\quad 22$ distillation tests of

Catron Creek, Ky., deposits on --- 106-107

Center County, Pa., cannel coal in -- 56 cannel coal in, distillation tests of -

Centertown, Mo., cannel coal near-- 116

Chemical composition of cannel coal_ 15-29

Chemicals, demand for

Chenoa, Ky., cannel coal at--- 34, 108-109

Chinns Branch, Ky., cannel coal on - 84

Classification of cannel coals_____ 10-11

Clay County, Ky., cannel coals in__- 111 cannel coals in, analyses of _._- 22

Clearfield County, Pa., cannel coals in -

cannel coals in, distillation tests of - 46 
Slover Fork, Ky., cannel coal on---

Coal oll, companies making in 1860 source of.

See also Oil.

Coke from cannel coal, quality of -yield of

Cole County, Mo., cannel coal in.--

Coon Creek, Ky., cannel coal on---

Cooper County, Mo., cannel coal in

Coshocton County, Ohio, cannel coals in cannel coals in, analyses of - distillation products of -.--

Cove Creek, W. Va., cannel coal on-

Crandall, A. R., cited and Sullivan, G. M., cited.- 107-108 cited 107-108

Crawford County, Mo., cannel coal in -

"Curly" cannel coal, structure of, plate showing

Cutshin Creek, Ky., cannel coal near.

D.

Daviess County, Ind., cannel coals in

cannel coals in, analyses of --

Defeated Creek, Ky., cannel coal on_

Definition of cannel coal.

Detroit, w. Va., cannel coal at_---

Distillation of cannel coals, products of

Dorsey, J. A., distillation tests by --

Downer Kerosene Oil Co., operations of

E.

East Point, Ky., cannel coal at_--Ebersole Branch, Ky., cannel coal on Elliott County, Ky., cannel coal in England. See Great Britain.

Entrances to mines, early and recent, plate showing -.--

Ethylene, value of, in coal gas --_--

Everman Creek, W. Va., cannel coal on

\section{F.}

Falling Rock, W. Va., cannel coal at Flambeau, Ky., cannel coal at Floyd County, Ky., cannel coal in. Folding, effect of

Fork Creek, W. Va., cannel coal on_

Fossils in cannel coal

Fracture of cannel coal_-_.-plate showing

Frozen Creek, Ky., cannel coal on.-

Fuel ratio, classification by definition of relation of, to specific gravity -Fugitt Branch, Ky., cannel coal on-Fugitt Creel, Ky., cannel coal on--Fulgate Fork, Ky., cannel coal on.-

74

89

94-95 8

Gre

G.
Gas, effect of temperature of car-

Page.

from cannel coals, candlepower of

making of

from gas coals, quantity and quality of

occluded, analyses of

yield of, per ton of coal carbonized-_._-_._- 38

Gases, hydrocarbon, heating value and candlepower of _..._ $\quad 37$

Georges Branch, Ky., cannel coal on-100

Georges Creek, Ky., cannel coal on -- $\quad 88$

Gesner, Abraham, cited._. 46-47

kerosene, made by__._._._._. 42

Gruin, even, in cannel coal_...-- 12

Great Britain, coals from, analyses of 20,28

coals from, distillation products of _

Greene, F. C., and Hinds, Henry, cited.- 34

Halsey, Ky., cannel coal at_____- 112-113 Hancock County, Ky., cannel coal in 113 cannel coal in, analyses of_-_-- 20,23 distillation tests of _._._-_- 46,47

Hinds,

and Greene, F. C., cited.-...-.-

W. Va., cannel coạl near. 82

Holmes County, Ohio, cannel coals in

cannel coals in, analyses of --- $\quad 26$

Hunnewell, Ky., cannel coal at_--- 83-84

Hydrocarbons, list of, from Breckinridge coal.

process for cracking sources of

\section{I.}

Igniting point_-_- 30

Illinois, cannel coals in cannel coals in, analyses of $\quad 21$ 
Indiana, cannel coals in.
cannel coals in, analyses of
mining of
production of
Indiana County, Pa., cannel coals
in
cannel coals in, analyses of
distillation tests of
Iowa, cannel coals in
cannel coals in, analyses of
production of

Ison Creek, Ky., cannel coal on.--

\section{J.}

Jack Bailey, Branch, cannel coal on -

Jackson, Ky., cannel coal near___- 95-96 Jackson County, Ky., cannel coals in - 100-101

cannel coals in, analyses of _-- 23

Jackson County, Ohio, cannel coals in

cannel coals in, analyses of

Japan, coal-tar products in

Jasper County, Mo., cannel coal in.

Jefferson County, Ohio, cannel coal in

Johns Branch, Ky., cannel coal on

Johnson County, Ky., cannel coals in

cannel coals in, analyses of 2- 19, 23 Julian, W. Va., cannel coal at_._- 80

\section{K.}

Kanawha County, W. Va., cannel

coals in

cannel coals in, analyses of distillation products of -.sections of, plate showing

Kane County, Utah, cannel coals from, analyses of _-__- 19,27

Kentucky, bituminous coals in, tests of

bituminous coals in, gas from.

cannel coals in

- 82-113

analyses of -־-_-_- 19, 21-26

distillation tests of

gas from

mining of _. 51-52, 53

production of _... 52-53, 82-83

eastern, map of, showing locations of cannel-coal deposits

Kentucky River, Middle Fork of, deposit on

North Fork of, deposit on

Kerosene, first oil known as........

Knott County, Ky., cannel coals in,

analyses of _._. 23

Knox County, Ky., cannel coal in - 109-111

cannel coal in, analyses of..-- 24

\section{L.}

La Salle County, Ill., cannel coal from, analysis of

82

104

104

42

24

21
Laurel County, Ky., cannel coal in.Laurel Fork, Ky., cannel coal on-.Laurel Fork, W. Va., cannel coal onLawrence County, Ky., cannel coal in

cannel coal in, analyses of -..-

Leatherwood Branch, Ky., cannel coal on - 97

Lens Creek, W. Va., cannel coal on- 75-76

Lesley, Ky., cannel coal at__._._._. $\quad 89$

Leslie County, Ky., cannel coals in_ 102 cannel coals in, analyses of _- 24

Letcher County, Ky., cannel coals in - 101-102

cannel coals in, analyses of _-_- 24

Lick Branch, Ky., cannel coal on_-- 105

Lick Creek, Ky., cannel coal on -.- 91

Licking County, Ohio, cannel coals in - 66-67 cannel coals in, analyses of _-.- $\quad 26$

Licking River, Ky., cannel coal on_- $\quad 93$

Lincoln County, Mo., cannel coal in $\quad 117$

Lincoln County, W. Va., cannel coals in 81

cannel coals in, analyses of -.-. $\quad 28$

Little Black Mountain, Ky., cannel coal on

Little Brushy Branch, Ky., cannel coal on _- 93

Little Caney Creek, cannel coal on 112

Little Fork of Little Sandy River, Ky., cannel coal on

Logan County, W. Va., cannel coal in - 82

Lost Creek, Ky., cannel coal on_--- 103

Lots Creek, Ky., cannel coal on _-_- 103

Lower Road Fork, Ky., cannel coal on- 110

Lula mine, near Philipsburg, Pa., alteration of coal in

Luster of cannel coal__._-

12

13

\section{M.}

McLean County, III., cannel coals incannel coals in, analyses of -..McLean County, Ky., cannel coal in, analysis of

69

21

24

78

Madison, W. Va., cannel coal near.Magoffin County, Ky., cannel coals in. cannel coals in, analyses of ---Mahoning County, Ohio, cannel coal in cannel coals in, analyses of _- $\quad 26$ Mammoth, W. Va., cannel coal near- 74-75 Marmet, W. Va., cannel coal at_-__ $\quad 75$ Martin Fork, Ky.; cannel coal in_._- 107 Maytown, Ky., cannel coal near__.- 91 Michigan, cannel coal in 69 Middle Fork, Ky., cannel coal on_-- 110 Mill Branch, Ky., cannel coal on_-.- 101 Miller County, Mo., cannel coal in_- 117 Mills Branch, Ky., cannel coal on:- 110 Millstone Branch, Ky., cannel coal on

Mining of cannel coal, cost of history of past and present, plate showing $\quad 34$ 
Missouri, cannel coal in

cannel coal in, production of --- 52-53 map of part of, showing locations of cannel-coal deposits__- 114

Mode of occurrence of cannel coal_- 31-34 Moore Creek, Ky., cannel coal on_- 109-110

Money Branch, cannel coal on 93-94

Moniteau County, Mo., cannel coal in

118

Montana, cannel coal in, production of

52

Mordecai Creek, Ky., cannel coal on.

Morgan County, $\mathrm{Ky}$., cannel coals in - 89-93 cannel coals in, analyses of _-_- 24-25

Morgan County, Mo., cannel coal in 118-119

Moshannon Creek, Pa., cannel coal on $57-58$

Mud River, W. Va., cannel coal on $78-79,81$

\section{N.}

Nature of cannel coal $8,9-10$

New Bedford, Mass., oil distilled at.

New Bethlehem, Pa., cannel coal south of

New Brunswick, albertite from, distillation products of ---

Nicholas County, W. Va., cannel coal in

Nichols Fork, Ky., cannel coal on Noble Branch, Ky., cannel coal on North Fork of Licking River,. Ky.,

cannel coal near-_-_-- 90-91

Nova Scotia, albertite from, gas from cannel coal from, analyses of.-

\section{o.}

Ohio, cannel coals in cannel coals in, analyses of gas from mining of production of

Oil, substitution of, for cannel coal_crude, difficulty of refining.

yield of, from cannel coals_ 10,47 illuminating, yield of, from cannel coals

paraffin, yield of, from cannel coals

See also Coal oil. $59-61$

73-74

95

99

63-67

26

37

$53-54$ $52-54$

49

Oil-making from cannel coal, history of

process of

Old Camp Branch, W. Va., cannel coal on - W. Va., cannel

Origin of cannel coal--- 8-9, 14-15, 30-31

Orton, Edward, cited.

Ouachita County, Ark., cannel coal in $119-121$

Owen, D. D., cited
Owsley County, Ky., cannel coals in, analyses of _..._..._-_ 20,25 cannel coals in, distillation test of

P.

Parafinin wax, process of making_--- $\quad 44$ yield of, from cannel coals__-_ $\quad 47$

Parke County, Ind., cannel coal in cannel coal in, analysis of -_-_ $\quad 20$

Patterson Creek, Ky., cannel coal on 112

Pennsylvania, cannel coals in cannel coals in, analyses of ---- 26-27 distillation tests of gas from mining of _-_._-____ 50,54 production of -_._-_._ 52-53,54. gas coals in, gas from

Perry County, Ind., cannel coals in_ 68-69 cannel coals in, analyses of _-_ $\quad 20$ distillation products of --- 47

Perry County, Ky., cannel coal in - 103-104 cannel coal in, analyses of _-_- 25 Peter, Robert, distillation tests by Peytona, W. Va., cannel coal near _- 77-78 Philipsburg, Pa., cannel coal in _._ 56 Physical properties of cannel coal_- 11-15 Pike County, Ky., cannel coal in_-- 93-94 cannel coal in, analyses of

Pineville, Ky., cannel coal near_- 107-108

Pittsburgh, Pa., oil distilled at_-_- $42-43$

Platt, W. G., cited___- 61-62

Pond Fork, W. Va., cannel coal on 80

Pond Gap, W. Va., cannel coal at-- $\quad \mathbf{7 4}$

Pond post office, W. Va., cannel coal near

Preston County, W. Va., cannel coal in

cannel coal in, analyses of

Prestonburg, Ky., cannel coal near-- 95

Prices of cannel coal__________ 55-56

Production of cannel coal__._- 52-54

Prospecting for cannel coal_____-_ 31

\section{Q.}

Queen Shoals, W. Va., cannel coal at_- 74

Quicksand Creek, Ky., cannel coal on

R.

Richmond, Pa., cannel coal near---Rittman, W. F., cracking process devised by

Robin Run, W. Va., cannel coal near Rock Creek, W. Va., cannel coal on Rock Fork, Ky., cannel coal on Roundbottom, W. Va., cannel coal near Rush Creek, Ky., cannel coal on 
S.

Saline County, Mo., cannel coal in -Salyersville, Ky., cannel coal near Sarah, Ky., cannel coal at.....Scioto County, Ohio, cannel coal in Scotland. See Great Britain.

Sections of cannel coal in Kanawha County, W. Va., plate showing --.--_-_-

Semicannel coal, distribution of ---Shale, grading of cannel coal into-Shale and coal, differences between Sharps Branch, Ky., cannel coal on Smith Branch, Ky., cannel coal on -Smoot Creek, Ky., cannel coal on--Somerville, Pa., cannel coal near.-South Quicksand Creek, Ky., cannel coal on

Sparks Branch, Ky., cannel coal on Spaws Creek, Ky., cannel coal on--Specific gravity of cannel coal Squabble Branch, Ky., cannel coal on Stacy Branch, Ky., cannel coal on Standard, W. Va., cannel coal at Stark County, Ohio, cannel coal from, analysis of

Sterling, W. Va., cannel coal near.-Stillwater Creek, cannel coal on Stinson Branch, W. Va., cannel coal on.

Stone Coal Branch, Ky., cannel coal on

Streak of cannel coal

Stress, effect of, on cannel coal_..-

Structure, block, of cannel coal...-block, of cannel coal, plate show-

Structure of " curly" or "bird'seye" cannel coal, plate showing Subcannel coals, analyses of
classification of

definition of

See also Analyses of cannel coals.

Sullivan, G. M., and Crandall, A. R., cited.

107-108

T.

Taff, J. A., cited.

119-120

Tar, products derived from 45,48

yield of, from cannel coa per ton of coal carbonized

Taylor, G. B., cited_-_-__-_ 49 38

Tennessee, cannel coal in cannel coal in, analyses of --- 27 production of

Texas, cannel coal in cannel coal in, analyses of .... production of 27

Torchlight, Ky, cannel coal near Trimble, D., cited.

Troublesome Creek, Ky., cannel coal on

Trumbull County, Ohio, cannel coal in, analysis of
Page.
119

93

87

88

We.

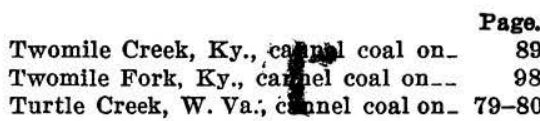

\section{U.}

United States, eastern, map of, showing locations of cannelcoal deposits

Upper Road Fork, Ky., cannel coal on

Upshur County, W. Va., cannel coal in 71

Uses of cannel coal__.

Utah, cannel coals in

cannel coals in, analyses of - 19, 27

Value of cannel coal___________- 54-56

Villa, W. Va., cannel coal at____- 74

Volatile matter, yield of, from .cannel coals

W.

Wacomah, W. Va., cannel coal at- 75 Wallins Creek, Ky., cahnel coal on_ 107 Wayne County, w. Va., cannel coal in 82

Webb County, Texas, cannel coals from, analyses of

Webster County, Iowa, cannel coal from, analysis of

Webster County, w. Va., cannel coal in

West Fork of Pond Fork, W. Va., cannel coal on

West Liberty, Ky., cannel coal at-- 91

West Virginia, cannel coals in cannel coals in, analyses of gas from_.. 38 mining of production of

gas coals in, gas from

Westmoreland County, Pa., cannel coal in - 59

White, David, cited....... 89, 120-121 White, I. C., cited____ 82

Whitehouse, Ky., cannel coal at _- 87 Whitley County, Ky., cannel coals in

cannel coals in, analyses of _- 25 Wilson Fork, Ky., cannel coal on -- 97 Wilson Fugate Branch, Ky., cannel coal on

Wolf Creek, Ky., cannel coal on 100 Wolfe County, Ky., cannel coals in $\quad 93$ cannel coals in, analyses of -- 26 Woodland, Pa., cannel coal at_.- 58 Workman Branch, W. Va., cannel coal on

Y.

Youghiogheny, Pa., coal, distillation test of 



\section{Lithomount}

Pamphlet

Binder

Gaylord Bros. Inc.

Makers

Syracuse, N. Y.

PAT. JAN 21, 1908 


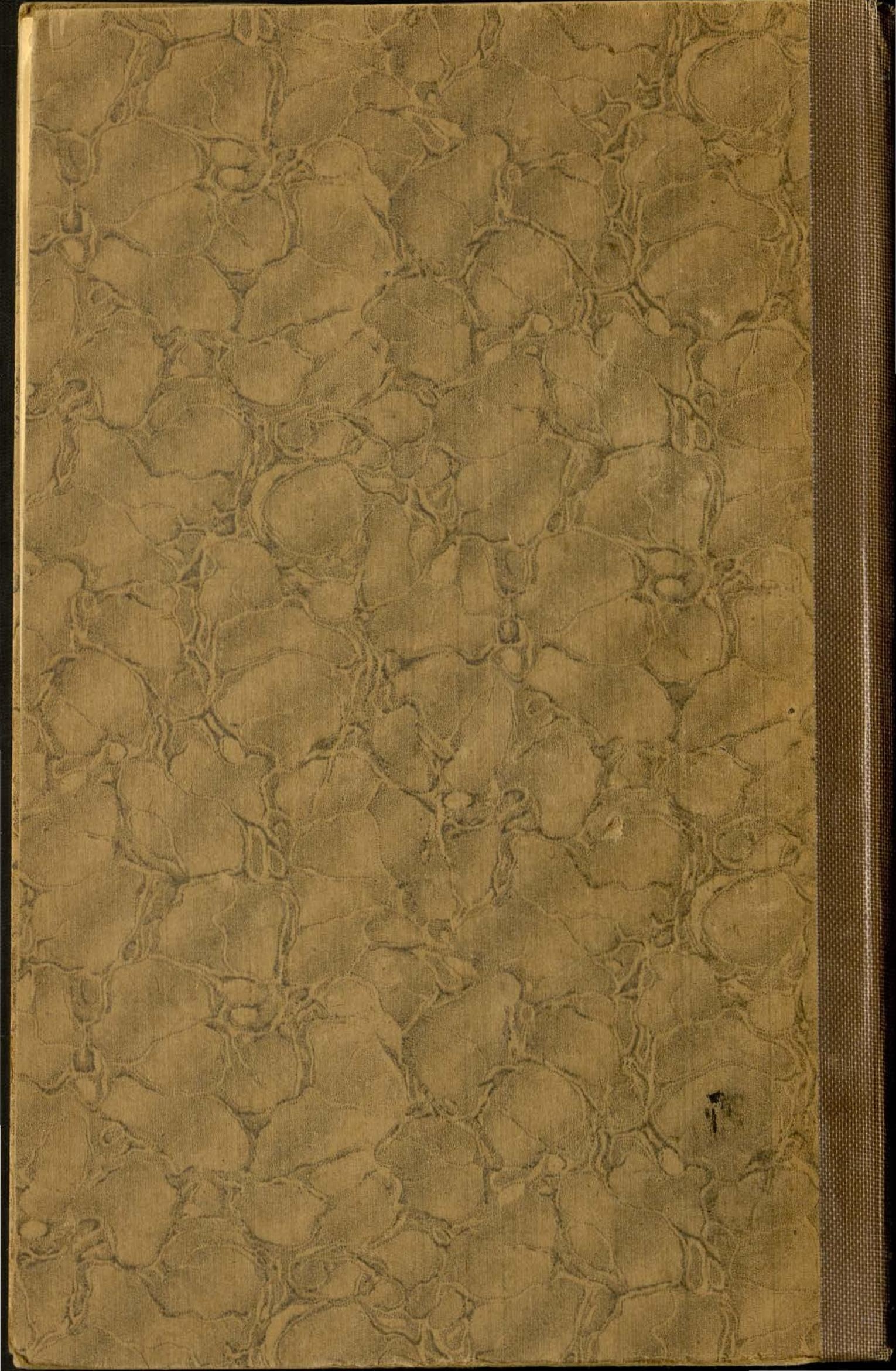

